Portland State University

PDXScholar

$1-1-2011$

\title{
Microbial Ecology of Active Marine Hydrothermal Vent Deposits: The Influence of Geologic Setting on Microbial Communities
}

Gilberto Eugene Flores

Portland State University

Follow this and additional works at: https://pdxscholar.library.pdx.edu/open_access_etds Let us know how access to this document benefits you.

Recommended Citation

Flores, Gilberto Eugene, "Microbial Ecology of Active Marine Hydrothermal Vent Deposits: The Influence of Geologic Setting on Microbial Communities" (2011). Dissertations and Theses. Paper 250.

https://doi.org/10.15760/etd.250

This Dissertation is brought to you for free and open access. It has been accepted for inclusion in Dissertations and Theses by an authorized administrator of PDXScholar. Please contact us if we can make this document more accessible: pdxscholar@pdx.edu. 
Microbial Ecology of Active Marine Hydrothermal Vent Deposits: The Influence of Geologic Setting on Microbial Communities

$$
\text { by }
$$

\title{
Gilberto Eugene Flores
}

\begin{abstract}
A dissertation submitted in partial fulfillment of the requirements for the degree of
\end{abstract}

\author{
Doctor of Philosophy \\ in \\ Biology
}

\author{
Dissertation Committee: \\ Anna-Louise Reysenbach, Chair \\ Michael Bartlett \\ Radu Popa \\ Parmely H. Pritchard \\ Mircea Podar \\ Dirk Iwata-Reuyl
}

Portland State University

(C) 2011 


\begin{abstract}
The discovery of deep-sea hydrothermal vents in 1977 revealed an ecosystem supported by chemosynthesis with a rich diversity of invertebrates, Archaea and Bacteria. While the invertebrate vent communities are largely composed of endemic species and exist in different biogeographical provinces, the possible factors influencing the distribution patterns of free-living Archaea and Bacteria are still being explored. In particular, how differences in the geologic setting of vent fields influence microbial communities and populations associated with active vent deposits remains largely unknown. The overall goal of the studies presented in this dissertation was to examine the links between the geologic setting of hydrothermal vent fields and microorganisms associated with actively venting mineral deposits at two levels of biological organization. At the community level, bar-coded pyrosequencing of a segment of the archaeal and bacterial $16 \mathrm{~S}$ rRNA gene was employed to characterize and compare the microbial communities associated with numerous deposits from several geochemically different vent fields. Results from these studies suggest that factors influencing endmember fluid chemistry, such as host-rock composition and degassing of magmatic volatiles, help to structure the microbial communities at the vent field scale. At the population level, targeted cultivation-dependent and -independent studies were conducted in order to expand our understanding of thermoacidophily in diverse hydrothermal environments. Results of these studies expanded the phylogenetic and physiological diversity of thermoacidophiles in deep-sea vent environments and
\end{abstract}


provided clues to factors that are influencing the biogeography of an important thermoacidophilic archaeal lineage. Overall, these studies have increased our understanding of the interplay between geologic processes and microorganisms in deepsea hydrothermal environments. 


\section{Dedication}

I dedicate this dissertation to my lovely wife, Sarah, and to my parents, Gilbert and Deborah, for their everlasting belief in me. 


\section{Acknowledgments}

First, I would like to thank my advisor, Anna-Louise Reysenbach, for teaching me how to be an academic scientist and providing me with numerous opportunities to broaden both my scientific and personal explorations. I would also like to thank my committee members, Michael Bartlett, Dirk Iwata-Reuyl, Mircea Podar, Radu Popa and Parmely (Hap) Pritchard, for their guidance throughout this process. Thanks to all my collaborators, especially Mircea Podar, Margaret (Meg) Tivey and Jeff Seewlad. Also, thanks to all crew members of the R/V Atlantis, R/V Thomas G. Thompson, R/V Roger Revelle, HOV Alvin and ROV Jason 2. I would also like to acknowledge and thank all past and present members of the Reysenbach laboratory, especially Yitai Liu, Jennifer Meneghin, Isabel Ferrera and Josh Steinberg, for help in the laboratory, insightful conversations and friendship. Without you I would not be here today. Finally, thanks to all my family and friends, especially my best friend and wife Sarah who risked her safety over the last several months while I earned little money and had my head in the deep-sea. Funding for this research was provided by the National Science Foundation through an IGERT fellowship and by grants OCE-0728391 and OCE-0937404 to AnnaLouise Reysenbach. 


\section{Table of Contents}

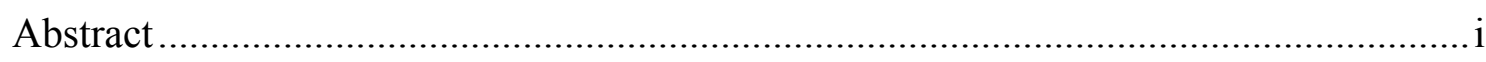

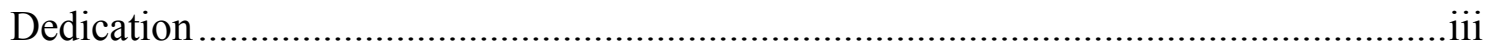

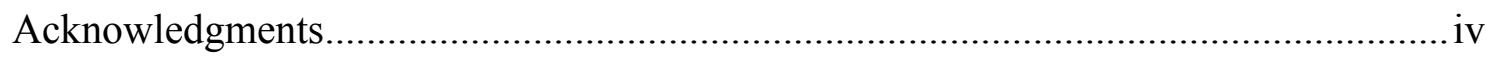

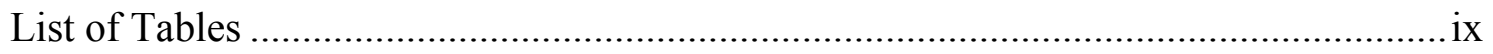

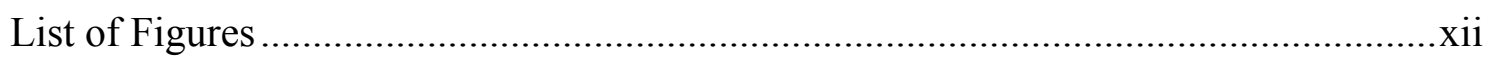

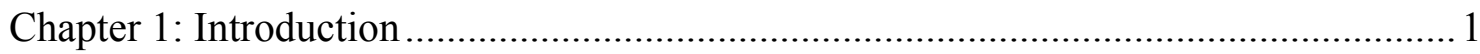

Preface

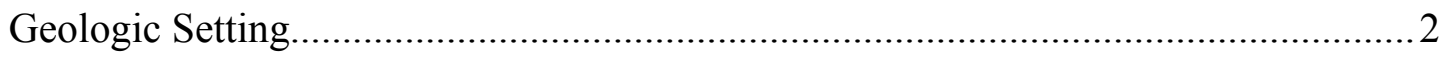

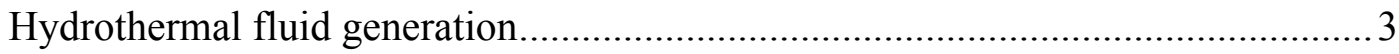

Hydrothermal mineral deposits..................................................................... 7

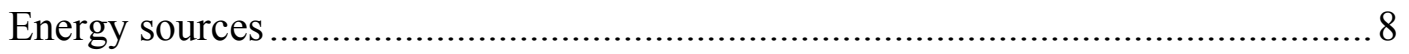

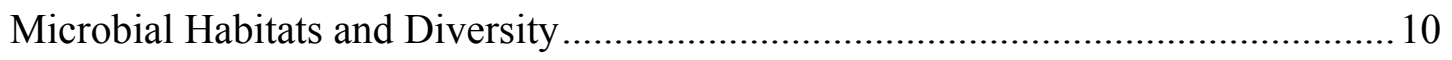

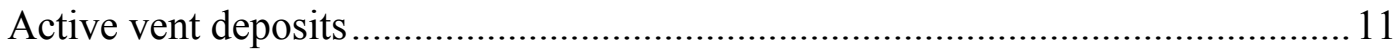

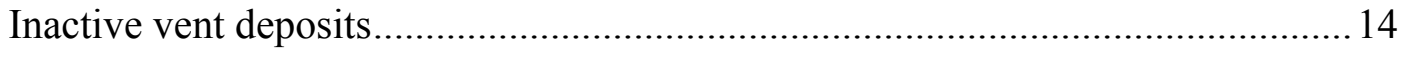

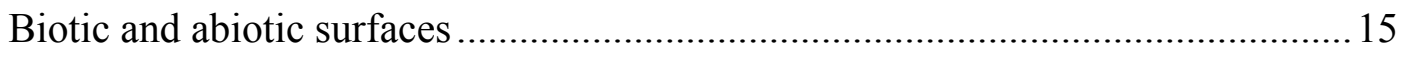

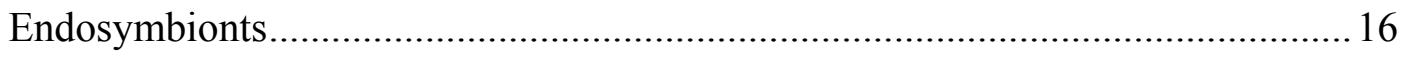

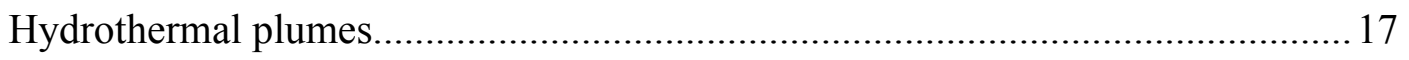

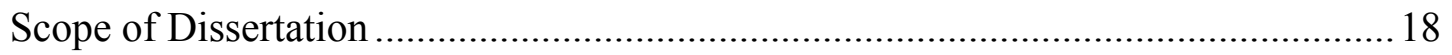

Chapter 2: Microbial Community Structure of Hydrothermal Deposits from

Geochemically Different Vent Fields Along the Mid-Atlantic Ridge...........................20 


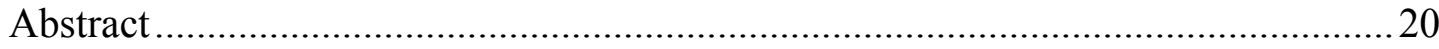

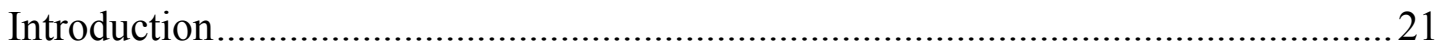

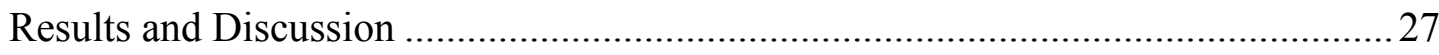

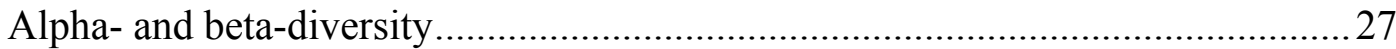

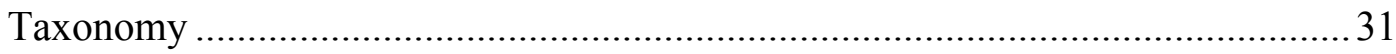

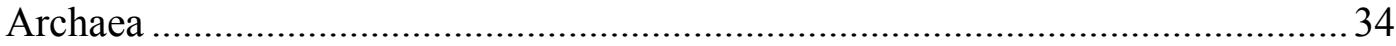

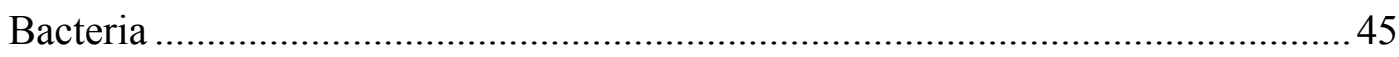

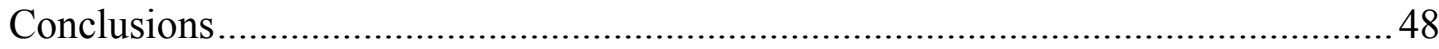

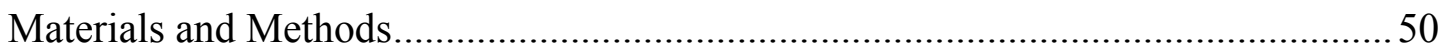

Sample collection and DNA extraction. .................................................. 50

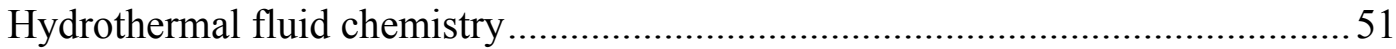

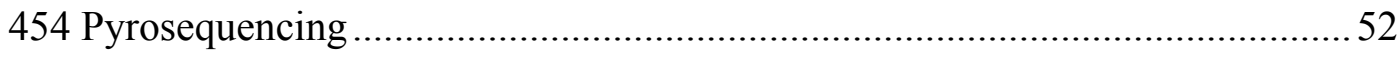

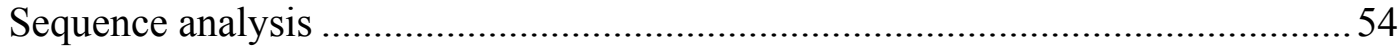

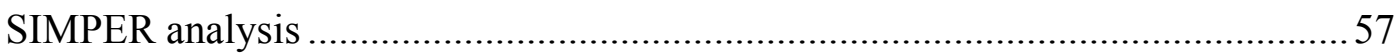

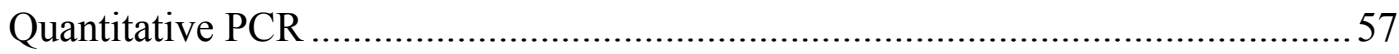

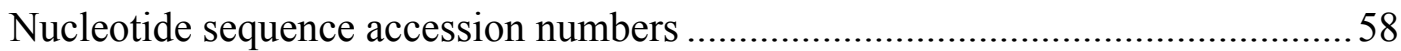

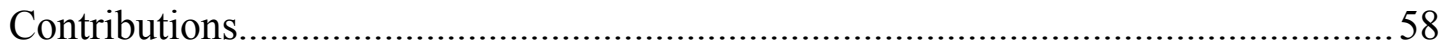

Chapter 3: Microbial Community Structure of Six Hydrothermal Vent Fields From the

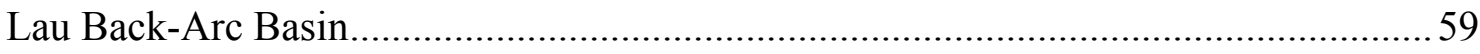

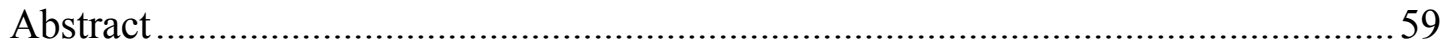

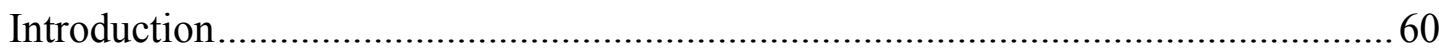

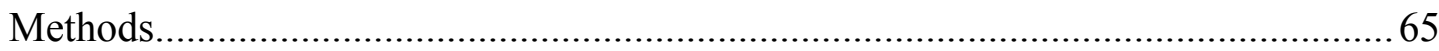




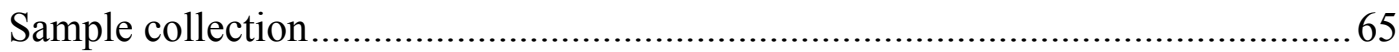

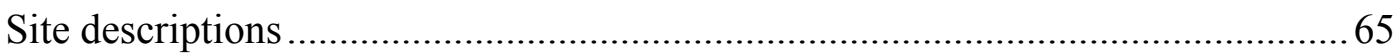

DNA extraction, pyrosequencing and sequence analysis .......................................69

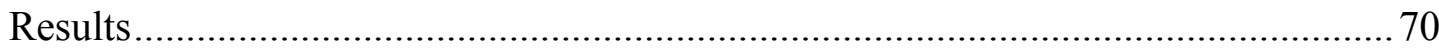

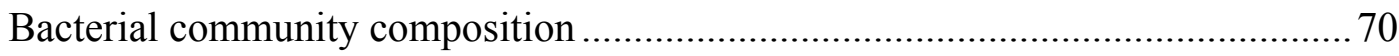

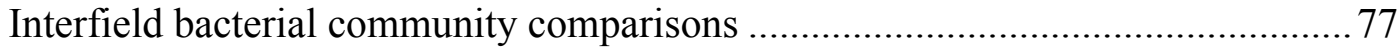

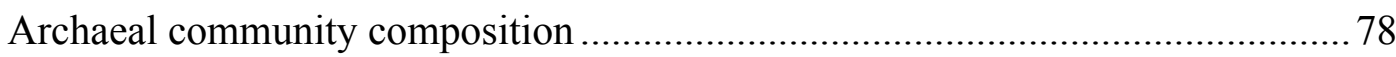

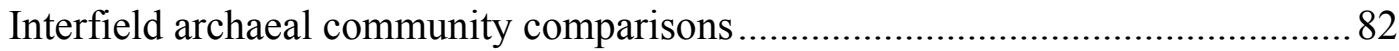

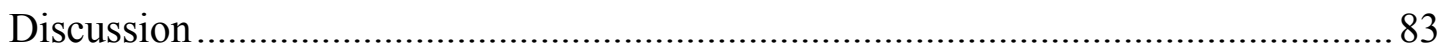

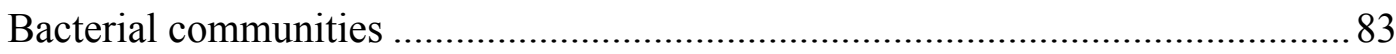

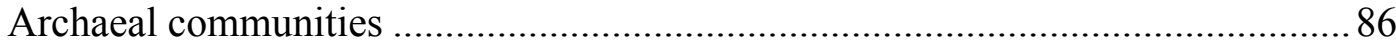

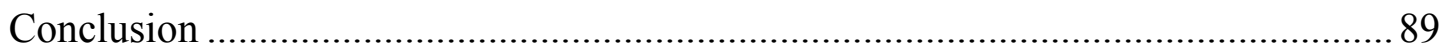

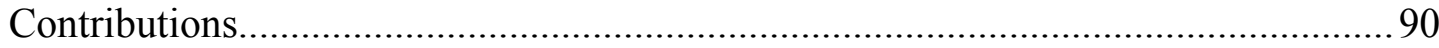

Chapter 4: Hippea jasoniae sp. nov. and Hippea alviniae sp. nov., Thermoacidophilic Deltaproteobacteria Isolated From Deep-Sea Hydrothermal Vent Deposits..................91

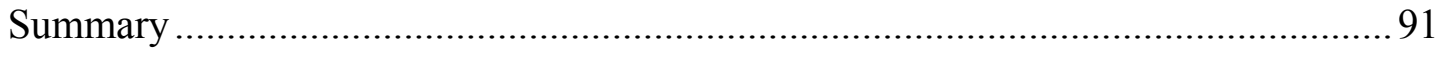

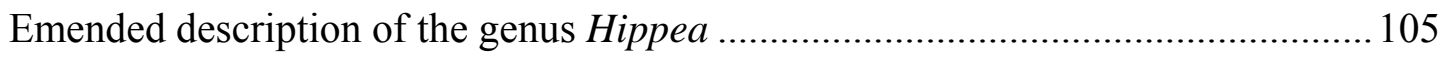

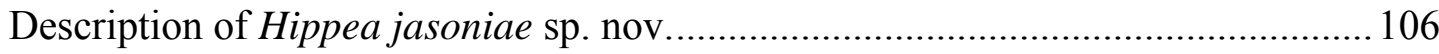

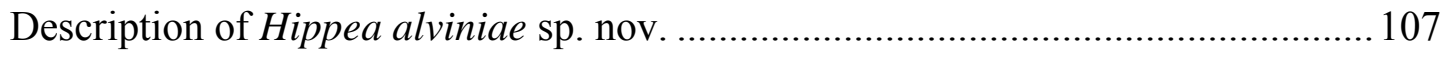

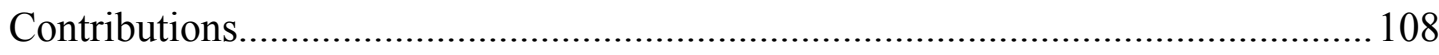

Chapter 5: Biogeography of the Thermoacidophilic Deep-Sea Hydrothermal Vent

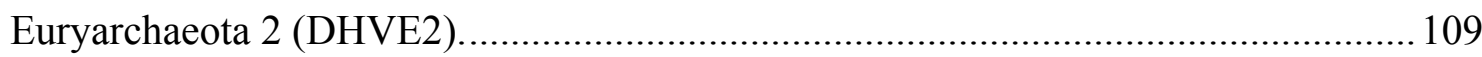


Abstract 109

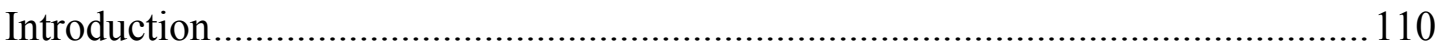

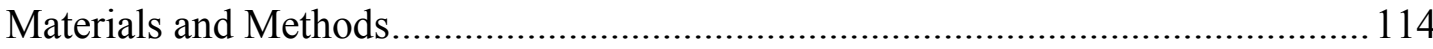

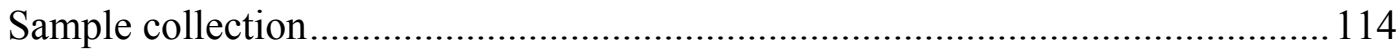

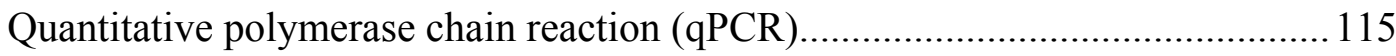

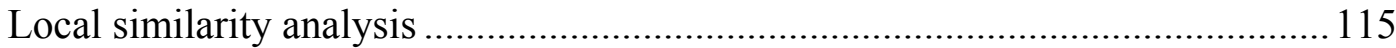

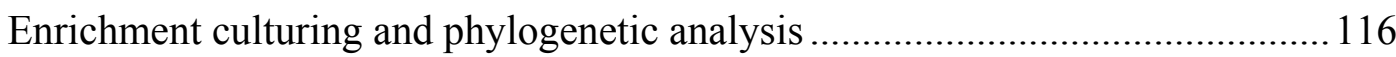

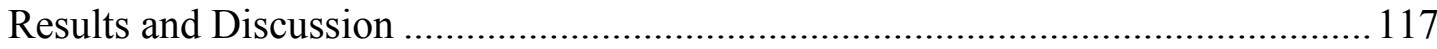

Occurrence and relative abundance of the DHVE2 ............................................... 117

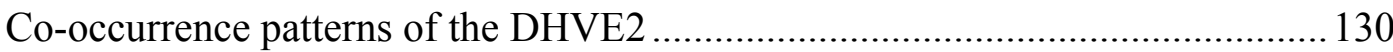

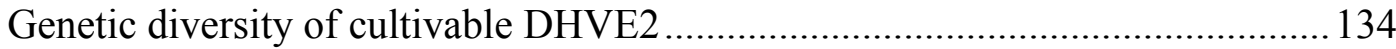

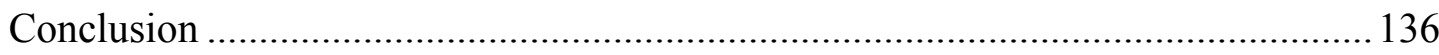

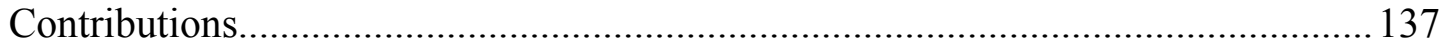

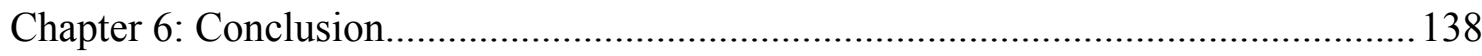

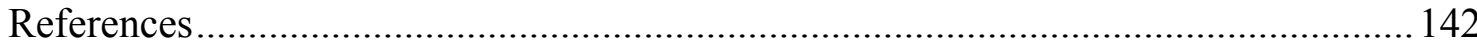

Appendix A: Sulfurihydrogenibium kristjanssonii sp. nov., a hydrogen and sulfuroxidizing thermophile isolated from a terrestrial Icelandic hot spring.......................... 173

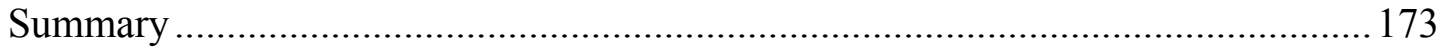

Appendix B: Electron microscopy encounters with unusual thermophiles helps direct

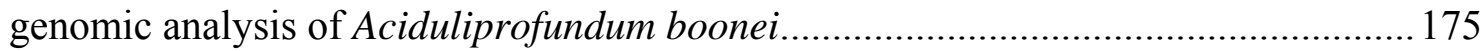

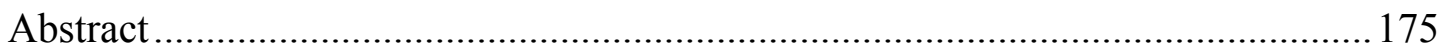

Appendix C: Summary of MAR 16S rRNA gene clones .......................................... 176 


\section{List of Tables}

Table 1.1. Representative chemical compositions of hydrothermal fluids from different geologic settings................................................4

Table 1.2. Examples of thermodynamically favorable redox reactions utilized by microorganisms from marine hydrothermal environments...................9

Table 2.1. Range of physico-chemical characteristics of end-member hydrothermal fluids from different vent fields along the Mid-Atlantic Ridge................22

Table 2.2. Hydrothermal vent deposits used to characterize the microbial communities from the Rainbow $(\mathrm{Rb})$ and Lucky Strike (LS) vent fields....................26

Table 2.3. Comparison of OTU richness and Chaol diversity estimates generated from two different clustering methods for archaeal and bacterial communities of hydrothermal vent deposits collected along the Mid-Atlantic Ridge............30

Table 2.4. SIMPER analysis was used to identify archaeal genera responsible for the dissimilarity observed in the communities of Rainbow and Lucky Strike vent deposits.

Table 2.5. End-member fluid chemistry of samples used for microbial community characterizations

Table 2.6. SIMPER analysis was used to identify bacterial genera responsible for the dissimilarity observed in the communities of Rainbow and Lucky Strike vent deposits. 
Table 3.1. Range of physico-chemical characteristics of end-member hydrothermal fluids from different vent fields along the Eastern Lau Spreading Center........64

Table 3.2. Hydrothermal deposits collected from the Eastern Lau Spreading Center used for microbial community characterization

Table 3.3. Results of AmpliconNoise analysis of four archaeal pyrosequencing libraries from vent deposits of the Eastern Lau Spreading Center. .71

Table 3.4. Results of pairwise comparisons of bacterial communities from different vent fields along the Eastern Lau Spreading Center using the ANOSIM test in Primer v6. .78

Table 3.5. Results of pairwise comparisons of archaeal communities from different vent fields along the Eastern Lau Spreading Center using the ANOSIM test in Primer v6.

Table 4.1. Location of hydrothermal vent fields where novel thermoacidophilic bacteria were isolated.

Table 4.2. Several of the new isolates and other Deltaproteobacteria have intervening sequences (IVSs) in their 16S rRNA genes.

Table 4.3. Comparison of physiological traits of four new isolates with Hippea maritima $\mathrm{MH} 2^{\mathrm{T}}$. 102

Table 5.1. Summary of $16 \mathrm{~S}$ rRNA gene sequences previously detected in marine hydrothermal environments. 
Table 5.2. Results of qPCR assays to determine the occurrence and relative abundance of the DHVE2 in hydrothermal vent deposits from several different vent fields. 119

Table 5.3. Results of qPCR assays to determine the occurrence and relative abundance of the DHVE2 in hydrothermal vent deposits from the East Pacific Rise (EPR). 121

Table 5.4. Results of qPCR assays to determine the occurrence and relative abundance of the DHVE2 in hydrothermal vent deposits from the Guaymas Basin. 122

Table 5.5. Results of qPCR assays to determine the occurrence and relative abundance of the DHVE2 in hydrothermal vent deposits from the Mid-Atlantic Ridge...124

Table 5.6. Results of qPCR assays to determine the occurrence and relative abundance of the DHVE2 in hydrothermal vent deposits from the Eastern Lau Spreading Center. .126

Table 5.7. Results of local similarity analysis illustrating the co-occurrence of the DHVE2 with other archaeal OTUs

Table 5.8. Hydrothermal vent deposits from which new DHVE2 isolates were obtained. 135 


\section{List of Figures}

Figure 1.1. Global distribution of known (red) hydrothermal venting along mid-ocean ridges, back-arc basins, rifted arcs, and at submerged island-arc volcanoes........3

Figure 1.2. Hydrothermal circulation along mid-ocean ridges depicting compositional changes of seawater and microbial habitats supported by hydrothermal fluids...6

Figure 2.1. Photographs of hydrothermal vent samples collected from the Rainbow and Lucky Strike vent fields.............................................25

Figure 2.2. Rarefaction analysis illustrates the greater diversity observed in the bacterial communities of twelve hydrothermal deposit samples collected from the Rainbow and Lucky Strike vent fields

Figure 2.3. 16S rRNA gene surveys reveal partitioning of the archaeal and bacterial communities between the ultramafic-hosted Rainbow (red) and basalt-hosted Lucky Strike (blue) vent fields along the Mid-Atlantic Ridge

Figure 2.4. 16S rRNA gene surveys reveal partitioning of the archaeal and bacterial communities between the ultramafic hosted Rainbow (red) and basalt-hosted Lucky Strike (blue) vent fields along the Mid-Atlantic Ridge. Communities clustered using MDS of the unweighted (A and D) and weighted (B and E) UniFrac distances for $\operatorname{archaeal}(\mathrm{A}, \mathrm{B})$ and bacterial $(\mathrm{D}, \mathrm{E})$ communities.........33

Figure 2.5. Comparison of taxonomic variation in the archaeal and bacterial communities of Rainbow and Lucky Strike hydrothermal vent deposits... 
Figure 2.6. Quantitative polymerase chain reaction assays targeting the gene diagnostic for methanogenesis (mcrA) confirms the absence of methanogens at Lucky Strike.

Figure 2.7. Concentrations across a uniformly porous $(\phi=0.5) 3-\mathrm{cm}$ thick chimney wall resulting from transport between seawater (at position $=-3 \mathrm{~cm}$ ) and $\mathrm{A}, 220^{\circ} \mathrm{C}$ Sintra vent fluid (Lucky Strike), B, $305^{\circ} \mathrm{C}$ Marker 6 vent fluid (Lucky Strike), $\mathrm{C}, 350^{\circ} \mathrm{C}$ Flores 5 vent fluid (Rainbow) at position $=0 \mathrm{~cm}$ by diffusion and advection of vent fluid outward at a rate of $2 \times 10-7 \mathrm{~m} \mathrm{~s}-1(\mathrm{u})$ .40

Figure 2.8. Concentrations across a uniformly porous $(\phi=0.5) 3-\mathrm{cm}$ thick chimney wall resulting from transport between seawater (at position $=-3 \mathrm{~cm}$ ) A, $220^{\circ} \mathrm{C}$ Sintra vent fluid (Lucky Strike), B, $305{ }^{\circ} \mathrm{C}$ Marker 6 vent fluid (Lucky Strike), C, 350

${ }^{\circ} \mathrm{C}$ Flores5 vent fluid (Rainbow) at position $=0 \mathrm{~cm}$ by diffusion only

Figure 2.9. Photograph of the hydrothermal vent chimney used for samples Rb-2 and

$\mathrm{Rb}-3$

Figure 2.10. Comparison of taxonomic variation in the bacterial communities of Rainbow and Lucky Strike hydrothermal vent deposits

Figure 3.1. Location of hydrothermal vent fields along the Eastern Lau Spreading Center in the western Pacific Ocean.....................................63

Figure 3.2. Location of deposits collected from each hydrothermal vent field along the Eastern Lau Spreading Center 68 
Figure 3.3. OTU richness (dark grey bars) and Chao1 diversity estimates (light grey bars) of bacterial diversity for each vent deposits characterized from the Eastern Lau Spreading Center................................................. 73

Figure 3.4. Rarefaction curves for bacterial communities of hydrothermal vent deposits from different vent fields along the Eastern Lau Spreading Center..............74

Figure 3.5. OTU richness (dark grey bars) and Chao1 diversity estimates (light grey bars) of archaeal diversity for each vent deposits characterized from the Eastern Lau Spreading Center................................................. 75

Figure 3.6. Relative abundance of epsilonproteobacterial genera (a) and other bacterial taxa (b) observed in hydrothermal vent deposits collected from the Eastern Lau Spreading Center....................................................... 76

Figure 3.7. Non-metric multidimensional scaling plots (MDS) based on Bray-Curtis similarities of the bacterial (a) and archaeal (b) communities of hydrothermal vent deposits from the Eastern Lau Spreading Center.........................77

Figure 3.8. Rarefaction curves for archaeal communities of hydrothermal vent deposits from different vent fields along the Eastern Lau Spreading Center..............79

Figure 3.9. Relative abundance of archaeal families (a) observed in individual deposits and average abundance of discriminating archaeal families (b) observed in deposits within individual vent fields along the Eastern Lau Spreading Center 81

Figure 4.1. Predicted secondary structure of intervening sequences in the 16S rRNA of several of the new isolates and close relatives.............................. 98 
Figure 4.2. Maximum-likelihood tree based on 16S rRNA gene sequence comparisons of thirteen novel thermoacidophilic Desulfurellaceae and other families of the Deltaproteobacteria .................................................. 101

Figure 4.3. Thin section electron micrographs of strains Mar08-272rT (a), Mar08-368r

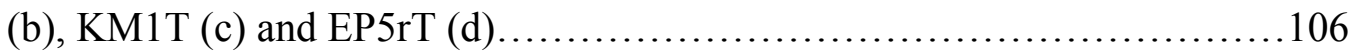

Figure 5.1. Photographs of a horizontal flange deposit (A) and vertical chimneys (B) from the Eastern Lau Spreading Center................................... 120

Figure 5.2. Results of local similarity analysis showing OTUs that are negatively (red lines) and positively (green lines) correlated with the DHVE2 (yellow

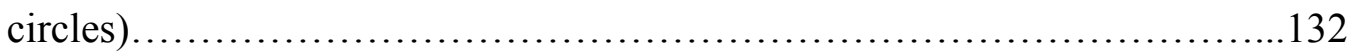

Figure 5.3. Neighbor-joining tree based on 16S rRNA gene sequence comparisons of 15 novel DHVE2 isolates and other archaeal families.........................137 


\section{Chapter 1: Introduction}

Flores, G. E. and Reysenbach, A.-L. (2011) Hydrothermal environments, marine. In Encyclopedia of Earth Science Series: Encyclopedia of Geobiology, J. Reitner, and V. Thiel (ed.), Springer, Dordrecht, The Netherlands, p. 456-466.

\section{Preface}

The discovery of deep-sea hydrothermal vents and the lush biological communities associated with these environments in the late 1970's ushered in a new era for marine biologists. Prior to this discovery, life in the deep-sea was thought to be dependent on the settling of detrital material from the productive overlaying surface waters. While this is true for much of the ocean basins, the level of production observed at these newly discovered vent sites was too great to be supported by these mechanisms alone. It soon became evident that life in these environments was supported by chemosynthetic primary production in which microorganisms harnessed the abundant geochemical energy available in the hydrothermal fluids. This challenged one of the basic ecological premises that all ecosystems on Earth were dependent on light energy and driven by photosynthetic primary production.

Since those initial revelations, research efforts have focused on assessing the microbial diversity and attempting to understand the intimate associations between microbial productivity, geology and geochemistry in marine hydrothermal 
environments. The following is a general discussion of the trends that are beginning to emerge from these efforts. Included in the discussion are overviews of the geologic setting of marine hydrothermal systems, the generation of hydrothermal fluids from different geologic settings and the types of mineral structures formed.

\section{Geologic Setting}

Most seafloor hydrothermal vent systems are associated with extensional tectonic activity and heated by magmatic heat as it is convected into the crust (Seyfried and Mottl, 1995). The most well studied areas of hydrothermal circulation are along divergent plate boundaries where basaltic seafloor is made and mid-ocean ridges (MOR) arise (Figure 1.1). Hydrothermal circulation along MORs results from the active heating of seawater that percolates through newly formed crust. Hydrothermal venting is also commonly found along convergent plate margins where an oceanic plate is subducted beneath a continental plate forming island arcs and back-arc basins. Vents along back-arc basins are actively heated in the same way as those along MOR, although the fluids tend to be more heterogeneous due to the variability in magma composition and additional inputs from the subducting plate. A third location where seafloor hydrothermal systems can be found is at intra-plate volcanic hot spots.

Volcanic hot spot systems are not directly associated with tectonic plate margins, but are actively heated as plumes of molten magma push up through the mantle and crust (Seyfried and Mottl, 1995). 


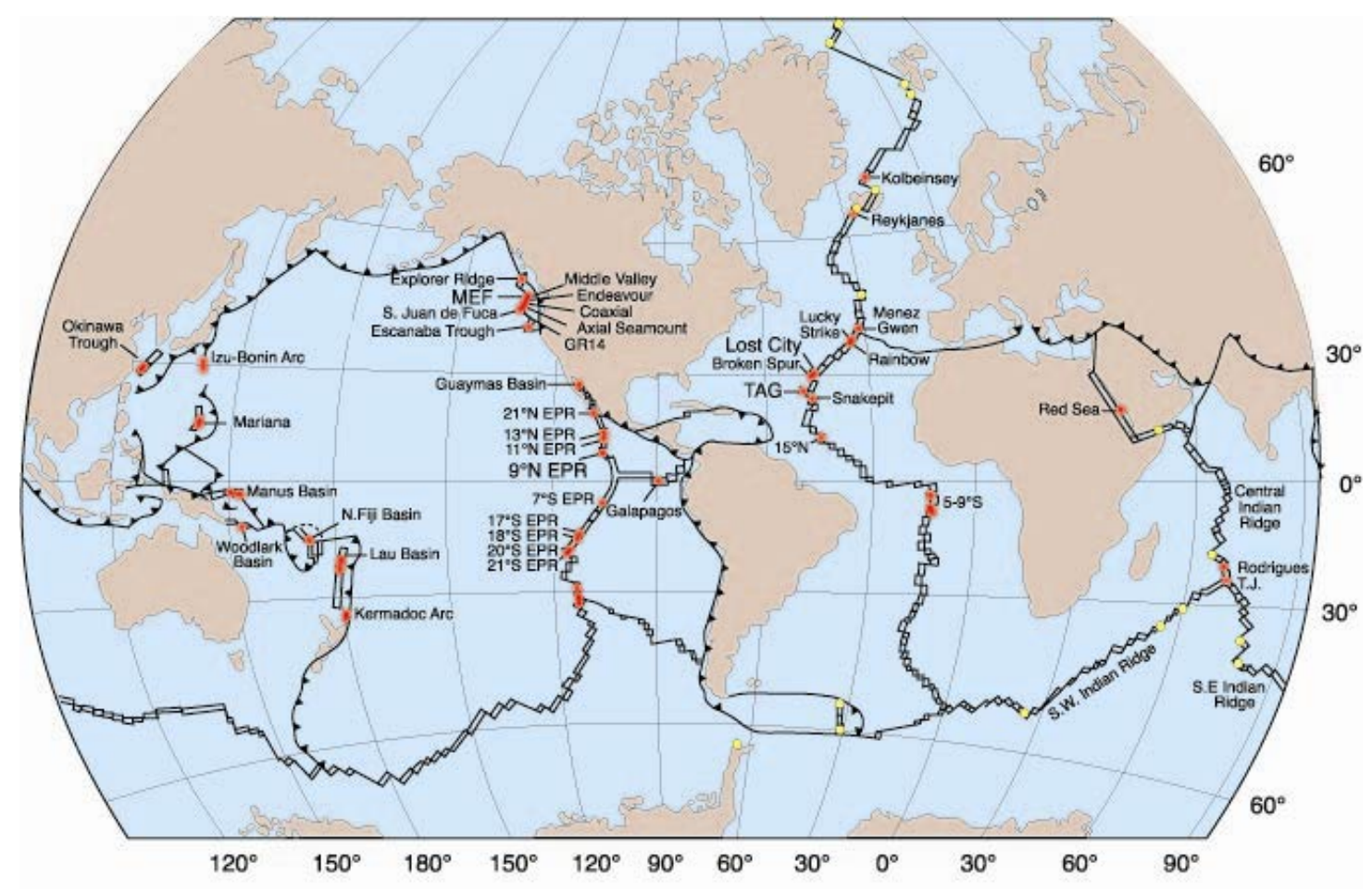

Figure 1.1. Global distribution of known (red) hydrothermal venting along mid-ocean ridges, back-arc basins, rifted arcs, and at submerged island-arc volcanoes. Yellow circles indicate areas where mid-water column chemical anomalies have been detected suggesting hydrothermal activity. $\mathrm{EPR}=$ East Pacific Rise, $\mathrm{TAG}=$ Trans Atlantic Geotraverse, $\mathrm{MEF}=$ Main Endeavour Field, and GR-14 = Sea Cliff hydrothermal field on the northern Gorda Ridge. Figure modified after (Tivey, 2007).

\section{Hydrothermal fluid generation}

Seawater heated in contact with subsurface rocks significantly alters the chemical composition of the end member fluids. The degree of alteration is influenced by several factors including the initial composition of the seawater, the type and structure of the host rock, the presence of sediment overlaying the host rock and the type, depth, and size of the heat source (Tivey, 2007). Understanding these interactions and how they affect the composition of hydrothermal fluids is important as the fluids set 
the physiological parameters and provide the metabolic menu for colonizing microbes. For comparison, representative compositions of hydrothermal fluids from different geologic settings are presented in Table 1.1.

Table 1.1. Representative chemical compositions of hydrothermal fluids from different geologic settings.

\begin{tabular}{|c|c|c|c|c|c|}
\hline & $\begin{array}{c}\text { Bottom } \\
\text { seawater }\end{array}$ & $\begin{array}{l}\text { Mid-ocean } \\
\text { ridge }\end{array}$ & $\begin{array}{l}\text { Back-arc } \\
\text { basin }\end{array}$ & $\begin{array}{l}\text { Sediment } \\
\text { hosted }\end{array}$ & $\begin{array}{c}\text { Ultramafic- } \\
\text { hosted vent field } \\
\text { (Rainbow) }\end{array}$ \\
\hline $\mathrm{T}\left({ }^{\circ} \mathrm{C}\right)$ & 2 & $\leq 405$ & $278-334$ & $100-315$ & 365 \\
\hline $\mathrm{pH}\left(25^{\circ} \mathrm{C}\right)$ & 8 & $2.8-4.5$ & $<1-5.0$ & $5.1-5.9$ & 2.8 \\
\hline $\mathrm{SO}_{4}, \mathrm{mmol} / \mathrm{kg}$ & 28 & 0 & 0 & 0 & 0 \\
\hline $\mathrm{Mg}, \mathrm{mmol} / \mathrm{kg}$ & 53 & 0 & 0 & 0 & 0 \\
\hline $\mathrm{Cl}, \mathrm{mmol} / \mathrm{kg}$ & 545 & $30.5-1245$ & $255-790$ & $412-668$ & 750 \\
\hline $\mathrm{Na}, \mathrm{mmol} / \mathrm{kg}$ & 464 & $10.6-983$ & $210-590$ & $315-560$ & 553 \\
\hline $\mathrm{Ca}, \mathrm{mmol} / \mathrm{kg}$ & 10.2 & $4.02-109$ & $6.5-89$ & $160-257$ & 67 \\
\hline $\mathrm{K}, \mathrm{mmol} / \mathrm{kg}$ & 10.1 & $1.17-58.7$ & $10.5-79$ & $13.5-49.2$ & 20 \\
\hline $\mathrm{H}_{2} \mathrm{~S}, \mathrm{mmol} / \mathrm{kg}$ & - & $0-19.5$ & $1.3-13.1$ & $1.10-5.98$ & 1 \\
\hline $\mathrm{H}_{2}, \mathrm{mmol} / \mathrm{kg}$ & - & $0.0005-38$ & $0.035-0.5$ & - & 13 \\
\hline $\mathrm{CO}_{2}, \mathrm{mmol} / \mathrm{kg}$ & 2.36 & $3.56-39.9$ & $14.4-200$ & - & - \\
\hline $\mathrm{CH}_{4}, \mathrm{mmol} / \mathrm{kg}$ & - & $0.007-2.58$ & $0.005-0.6$ & - & $0.13-2.2$ \\
\hline $\begin{array}{l}\mathrm{NH}_{3}, \\
\mathrm{mmol} / \mathrm{kg}\end{array}$ & - & $<0.65$ & - & $5.6-15.6$ & - \\
\hline $\mathrm{Fe}, \mu \mathrm{mol} / \mathrm{kg}$ & - & $7-18700$ & $13-2500$ & $0-180$ & 24000 \\
\hline $\mathrm{Mn}, \mu \mathrm{mol} / \mathrm{kg}$ & - & $59-3300$ & $12-7100$ & $10-236$ & 2250 \\
\hline $\mathrm{Cu}, \mu \mathrm{mol} / \mathrm{kg}$ & - & $0-150$ & $0.003-34$ & $<0.02-1.1$ & 140 \\
\hline $\mathrm{Zn}, \mu \mathrm{mol} / \mathrm{kg}$ & - & $0-780$ & 7.6-3000 & $0.1-40$ & 160 \\
\hline $\mathrm{Pb}, \mu \mathrm{mol} / \mathrm{kg}$ & - & $0.183-0.1630$ & $0.036-3.9$ & $<0.02-0.652$ & 0.148 \\
\hline
\end{tabular}

Modified after Tivey (2007). 
Water-rock reactions begin as cold seawater infiltrates shallow crustal-rocks in the recharge zones (Figure 1.2). Initial low temperature reactions $\left(\leq 60^{\circ} \mathrm{C}\right)$ result in the removal of alkali metals from seawater and the oxidation of basaltic minerals (e.g., olivine and plagioclase) with the concomitant leaching of silica ( $\mathrm{Si}$ ), sulfur (S), and sometimes magnesium (Mg) from the minerals (Alt, 1995). Magnesium is eventually completely removed from the fluids as Mg-rich clays precipitate at temperatures above $150^{\circ} \mathrm{C}$. Anhydrite $\left(\mathrm{CaSO}_{4}\right)$ precipitation and seawater sulfate $\left(\mathrm{SO}_{4}{ }^{2-}\right)$ reduction also occurs in the recharge zone at temperatures above $150^{\circ} \mathrm{C}$ resulting in the complete removal of $\mathrm{SO}_{4}{ }^{2-}$ from the fluids. As the fluid continues through the crust, reactions with iron-bearing minerals like olivine and pyroxene result in highly reducing fluids with elevated concentrations of hydrogen gas $\left(\mathrm{H}_{2}\right)$ (Tivey, 2007). Upon reaching the reaction zone where fluids are heated upwards of $400^{\circ} \mathrm{C}$, the fluid obtains its chemical signature by leaching $\mathrm{S}$ and metals (copper-Cu, iron-Fe, manganese-Mn, zinc-Zn) from the surrounding rocks (Alt, 1995). Phase separation may also occur in the reaction zone if temperature and pressure are greater than $407^{\circ} \mathrm{C}$ and 298 bars, respectively (Von Damm, 1995). Phase separation can have a significant impact on the composition of end member fluids as volatiles like hydrogen-sulfide $\left(\mathrm{H}_{2} \mathrm{~S}\right)$ tend to partition in the vapor phase while metals like Fe become enriched in the liquid (brine) phase. Gasses such as helium $(\mathrm{He})$, methane $\left(\mathrm{CH}_{4}\right)$ and carbon-dioxide $\left(\mathrm{CO}_{2}\right)$ may also be added to the hydrothermal fluids as volatiles from the underlying magma (Alt, 1995). In total, these reactions result in end member fluids that are acidic $(\mathrm{pH} 2.8-4.5)$, highly reduced, rich in $\mathrm{H}_{2} \mathrm{~S}$ and metals, and up to $400^{\circ} \mathrm{C}$. The fluid is also extremely buoyant relative to 
seawater and is forced back to the seafloor through the discharge zone and may emerge as diffuse or focused flow depending on the degree of subsurface mixing during the ascent (Figure 1.2).

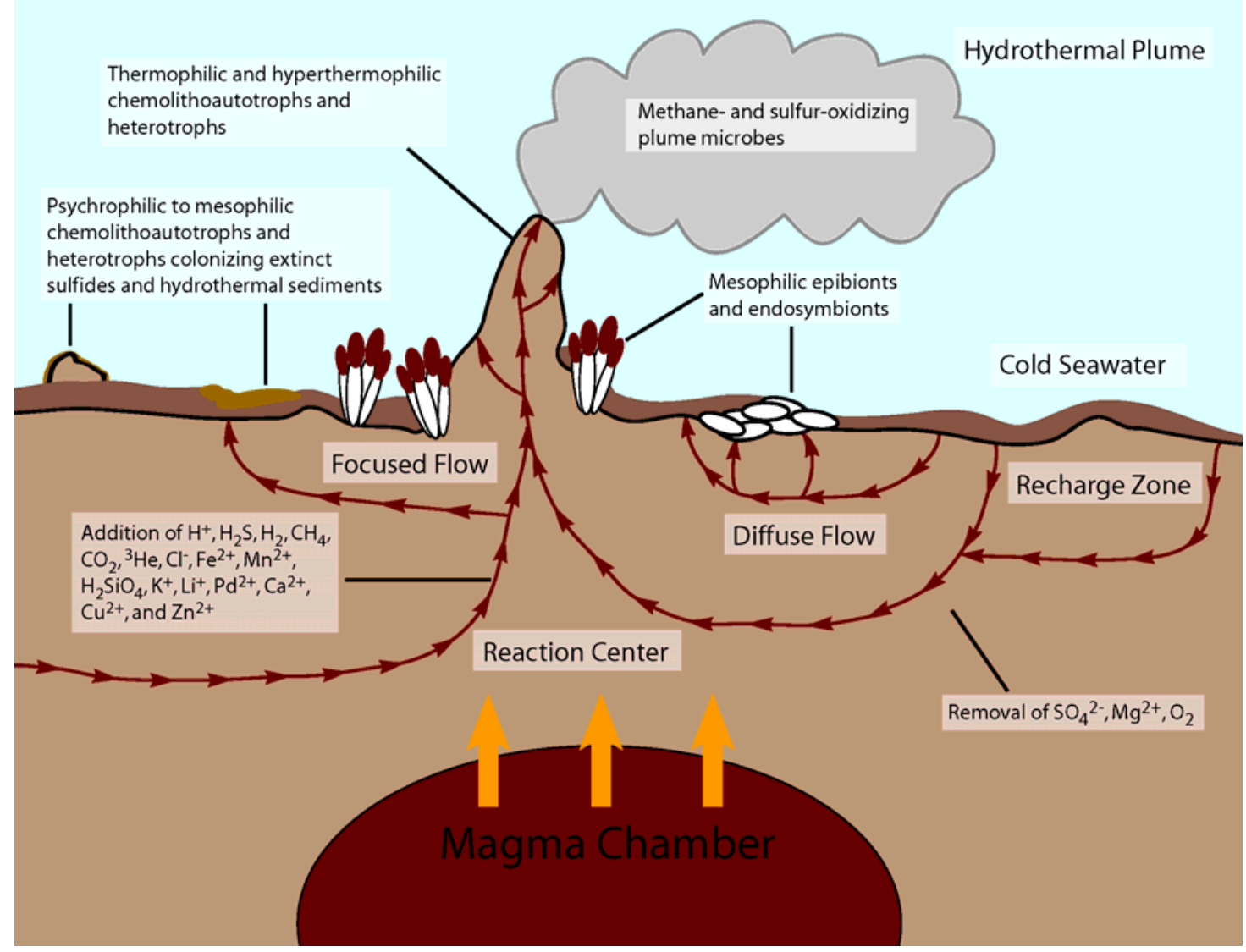

Figure 1.2. Hydrothermal circulation along mid-ocean ridges depicting compositional changes of seawater and microbial habitats supported by hydrothermal fluids. Small arrows indicate fluid flow while large arrows indicate heat transfer from magmatic source. Image is not drawn to scale.

While the transformations described above generally apply to all marine hydrothermal environments, other factors, such as differences in host rock composition and sediment cover, can contribute to the geochemistry of end member fluids. The 
impact that different host rocks have on fluid chemistry is best illustrated by the ultramafic-hosted (peridotite) Rainbow vent field along the Mid-Atlantic Ridge (Douville et al., 2002). Fluids from Rainbow vent field are lower in $\mathrm{pH}$, have much higher Fe concentrations, are enriched in $\mathrm{H}_{2}$ and $\mathrm{CH}_{4}$, and are depleted in $\mathrm{H}_{2} \mathrm{~S}$ relative to fluids from most MOR systems (McCollom, 2007). Sediments overlying the host rock, as is seen in the Guaymas Basin, can also affect the composition of end-member fluids. In general, sediment hosted systems generate fluids that are higher in $\mathrm{pH}$ (5.1 5.9) and lower in metal contents than those from unsedimented systems. Chemical differences largely depend on the amount and type of organic matter present in the sediments (Tivey, 2007).

\section{Hydrothermal mineral deposits}

When acidic hydrothermal fluids rich in reduced chemical species interact with cold, oxygenated seawater, minerals rapidly precipitate out of solution forming large mineral deposits (Juniper and Tebo, 1995). Mineral phases found in these deposits include sulfides, sulfates, oxides, hydroxides, silicates and carbonates. Deposit formation can occur in the subsurface as the fluids ascend through oceanic crust and mix with infiltrating seawater or directly on the seafloor as high temperature fluids erupt into bottom seawater. Subsurface precipitation of minerals generates stockwork deposits in the shallow crust and results in low-temperature venting on the seafloor. Low-temperature fluids are generally low in metal-sulfides and as result, precipitate oxides upon reaching the seafloor. In contrast, fluids that have not been diluted and 
cooled in the subsurface rapidly precipitate metal sulfides like pyrite $\left(\mathrm{FeS}_{2}\right)$, chalcopyrite $\left(\mathrm{CuFeS}_{2}\right)$ and sphalerite $(\mathrm{ZnS})$ upon mixing with seawater. Precipitation of metal sulfides results in the appearance of "black smoke" and ultimately forms massive sulfide deposits ( $>60 \%$ sulfide minerals). Several types of sulfide features are found in vent fields with the most spectacular being the black smoker chimney. Other sulfide structures generated at marine hydrothermal vents include diffuse flow beehives, horizontal shelf-like flanges and complex flow sulfide mounds (Van Dover, 2000). In all cases, active deposits provide extreme physical and geochemical gradients that sustain diverse microbial populations.

\section{Energy sources}

Seafloor hydrothermal ecosystems are supported primarily by chemosynthetic primary production fueled by the chemical disequilibrium between the oxygenated seawater and the reduced hydrothermal fluids. Microorganisms capture this energy by way of reduction/oxidation (redox) reactions in which seawater typically provides the oxidant $\left(\mathrm{O}_{2}, \mathrm{SO}_{4}{ }^{2-}, \mathrm{NO}_{3}{ }^{-}, \mathrm{CO}_{2}\right)$ and the hydrothermal fluids provide the reductant $\left(\mathrm{H}_{2}\right.$, $\left.\mathrm{H}_{2} \mathrm{~S}, \mathrm{HS}^{-}, \mathrm{S}^{0}, \mathrm{~S}_{2} \mathrm{O}_{2}{ }^{3-}, \mathrm{Fe}^{2+}\right)$. Redox reactions generate energy that is used to fix $\mathrm{CO}_{2}$ into cellular material that then provides organic carbon for various heterotrophic microbes and animals that make up the remainder of the community. Examples of thermodynamically favorable reactions found in marine hydrothermal environments are presented in Table 1.2. 
Table 1.2. Examples of thermodynamically favorable redox pairs utilized by microorganisms from marine hydrothermal environments.

\begin{tabular}{ccccc} 
Conditions & Electron donor & Electron acceptor & $\begin{array}{c}\text { Free energy } \\
\Delta \mathrm{G}^{\mathrm{a}}(\mathrm{kJ} / \mathrm{mol})\end{array}$ & Metabolic Process \\
\hline Aerobic & $\mathrm{H}_{2}$ & $\mathrm{O}_{2}$ & -237 & hydrogen oxidation \\
& $\mathrm{HS}^{-}$ & $\mathrm{O}_{2}$ & -797 & sulfide oxidation \\
& $\mathrm{S}^{0}$ & $\mathrm{O}_{2}$ & -585 & sulfur oxidation \\
& $\mathrm{S}_{2} \mathrm{O}_{2}{ }^{3-}$ & $\mathrm{O}_{2}$ & -952 & thiosulfate oxidation \\
& $\mathrm{Fe}^{2+}$ & $\mathrm{O}_{2}$ & -44.3 & iron oxidation \\
& $\mathrm{NH}^{4+}$ & $\mathrm{O}_{2}$ & -275 & nitrification \\
& $\mathrm{CH}_{4}+$ other & $\mathrm{O}_{2}$ & $\sim 810$ & methane oxidation \\
& $\mathrm{C}-1$ compounds & $\mathrm{O}_{2}$ & $\sim 477$ & heterotrophic metabolism \\
& Organics & & & \\
& & $\mathrm{NO}_{3}{ }^{-}$ & -239 & denitrification \\
Anaerobic & $\mathrm{H}_{2}$ & $\mathrm{~S}^{0}$, & -98.3 & sulfur reduction \\
& $\mathrm{H}_{2}$ & $\mathrm{SO}_{4}{ }^{2-}$ & -38.1 & sulfate reduction \\
& $\mathrm{H}_{2}$ & $\mathrm{CO}_{2}$ & -34.7 & methanogenesis \\
& $\mathrm{H}_{2}$ & $\mathrm{SO}_{4}{ }^{2-}$ & $\sim 40.6$ & heterotrophic sulfate reduction \\
& Organics & $\mathrm{S}^{0}$ & $\sim 25.1$ & heterotrophic sulfur reduction \\
& Organics & $\mathrm{Organics}^{2}$ & $\sim 38.5$ & fermentation \\
\hline
\end{tabular}

Complied and adapted from Jannasch (1995), and Karl (1995b).

${ }^{\mathrm{a}}$ Values calculated using standard conditions $\left(\mathrm{pH} 7,25^{\circ} \mathrm{C}, 1 \mathrm{~atm}\right)$

bexample reaction calculated from acetate + ethanol $\rightarrow$ butyrate + water.

Reactions are expressed in terms of the change in free energy $(\Delta \mathrm{G})$ where the more negative the value the more energy an organism will gain by catalyzing the reaction. Calculated values suggest that aerobic oxidation of reduced sulfur compounds $\left(\mathrm{HS}^{-}, \mathrm{S}^{0}, \mathrm{~S}_{2} \mathrm{O}_{2}{ }^{3-}\right.$ ) are the most energetically favorable and potentially the most significant reactions in terms of biomass production in marine hydrothermal environments. Thermodynamic calculations, however, can be misleading as they do not consider the bioavailability of certain reactants and potential kinetic inhibition under different environmental conditions (Takai et al., 2006a). Several past studies have attempted to model the overall energetics in a variety of marine hydrothermal systems considering such factors (McCollom and Shock, 1997; McCollom, 2000; McCollom, 
2007). An interesting conclusion from a theoretical study is that four times as much energy per $\mathrm{kg}$ of hydrothermal fluid is available to $\mathrm{H}_{2}$-oxidizers in ultramafic hosted systems than to sulfur-oxidizers because of the increase concentrations of $\mathrm{H}_{2}$ (McCollom, 2007). This suggests that $\mathrm{H}_{2}$-oxidizers may be more important than sulfuroxidizers in ultramafic hosted systems. A recent report lends support to this hypothesis as the diversity of $\mathrm{H}_{2}$-oxidizing bacteria was found to increase as the concentration of $\mathrm{H}_{2}$ gas increased in vents sampled from the ultramafic hosted Logatchev vent field along the MAR (Perner et al., 2007). These studies speak to the tight coupling of geochemistry and microbial primary production in marine hydrothermal environments.

\section{Microbial Habitats and Diversity}

Seafloor hydrothermal systems provide several habitats over a wide range of physical environments that sustain distinct microbial communities. Such environments include active and inactive vent deposits, biotic and abiotic surfaces receiving hydrothermal fluid inputs, inside vent animals (endosymbionts) and hydrothermal vent plumes (Figure 1.2) (Karl, 1995a; Van Dover, 2000; Takai et al., 2006a). Many of these environments are exposed to varying inputs of hydrothermal fluids resulting in fluctuating temperatures and chemistry. Below is a brief discussion of each of these habitats and their associated microbial biodiversity. These biodiversity assessments are based on growing and characterizing isolates under laboratory conditions (cultivationdependent) and through molecular phylogenetic approaches that are cultivationindependent. This latter approach is based on extracting genomic DNA from 
environmental samples, and then amplifying a section of a diagnostic phylogenetic marker for Bacteria and Archaea, the small subunit rRNA gene (16S rRNA), using the polymerase chain reaction (PCR).

Active vent deposits

Using cultivation-dependent and cultivation-independent techniques, a rich diversity of Bacteria and Archaea has been found associated with active vent deposits (Jannasch, 1995; Karl, 1995b; Takai et al., 2006a). Free-living microorganisms supported by active deposits include mesophilic, thermophilic and hyperthermophilic chemolithoautotrophs, heterotrophs and mixotrophs. Organisms can be anaerobes, facultative anaerobes, microaerophiles and obligate aerobes. In general, Bacteria are the most numerically abundant microorganisms associated with vent deposits (Jannasch, 1995; Karl, 1995b; Takai et al., 2006a). Their abundance can range anywhere from 35 $-99 \%$ of the microbial population depending on the method used to measure abundance (e.g., FISH, qPCR, MPN), the type of vent structure (e.g., chimney, flange, diffuse flow beehive), and where within a deposit one examines (e.g., outer, inner) (Harmsen et al., 1997; Takai and Horikoshi, 1999; Takai et al., 2001; Hoek et al., 2003; Schrenk et al., 2003; Nakagawa et al., 2006).

Within the Bacteria, members of the Epsilonproteobacteria consistently dominate microbial communities in deep-sea hydrothermal environments (Reysenbach et al., 2000; Hoek et al., 2003; Nakagawa et al., 2005c; Campbell et al., 2006). These free-living deep-sea Epsilonproteobacteria are mesophilic to moderately thermophilic. 
Recently, several representatives have been obtained in pure culture that are chemolithoautotrophs capable of oxidizing $\mathrm{H}_{2}$ and sulfur compounds while using $\mathrm{O}_{2}$, $\mathrm{NO}_{3}{ }^{-}$or sulfur compounds as terminal electron acceptors (Campbell et al., 2006). Like in cave environments, the Epsilonproteobacteria play an essential role in sulfur and carbon cycling at deep-sea vents.

Other commonly identified but less abundant bacterial members of the freeliving microbial communities include the thermophilic Aquificales and Thermotogales, as well as other classes of Proteobacteria (Miroshnichenko and Bonch-Osmolovskaya, 2006). The Aquificales are globally distributed at marine hydrothermal environments but are restricted to active deposits and hydrothermal fluids due to their thermophilic lifestyle. They are generally chemolithoautotrophs and chemoorganotrophs capable of oxidizing $\mathrm{H}_{2}, \mathrm{~S}^{0}$ and $\mathrm{S}_{2} \mathrm{O}_{3}{ }^{2-}$ either aerobically or anaerobically with $\mathrm{NO}_{3}{ }^{-}$or sulfur compounds as electron acceptors. The Thermotogales, on the other hand, are strictly anaerobic, thermophilic heterotrophic fermenters (Boone et al., 2001).

As stated above, Archaea are less abundant in active vent deposits, yet they play a key biogeochemical role especially at the higher temperatures. Some of the most exhaustive studies on microbial diversity at deep-sea vents have focused solely on the Archaea revealing a high phylogenetic and metabolic diversity within this domain (Takai and Horikoshi, 1999; Takai et al., 2001; Nercessian et al., 2003; McCliment et al., 2006). Most of the Archaea found here are thermophilic to hyperthermophilic and are thus restricted to areas most influenced by hydrothermal fluids. Within the Archaea, the two main phyla, the Crenarchaeota and Euryarchaeota, are well represented at 
deep-sea vents, while the enigmatic Korarchaeota and Nanoarchaeota are occasionally detected (Takai et al., 2006a).

Crenarchaeota commonly detected in deep-sea vent deposits include cultivated members of the Desulfurococcales (e.g., Pyrodictium and Pyrolobus) and several uncultivated groups like the deep-sea hydrothermal vent crenarchaeotal group (DHVC1), and the marine group I (Takai and Horikoshi, 1999; Takai et al., 2006a). Pyrodictium is an example of a hyperthermophilic mixotrophic organism with the ability to use either $\mathrm{H}_{2}$ or complex organics to reduce elemental sulfur (Reysenbach et al., 2002). Pyrolobus is also a hyperthermophile but, unlike Pyrodictium, Pyrolobus is an obligate chemolithoautotroph that can only use $\mathrm{H}_{2}$ to reduce nitrate $\left(\mathrm{NO}_{3}{ }^{-}\right)$, thiosulfate $\left(\mathrm{S}_{2} \mathrm{O}_{2}{ }^{3-}\right)$ or $\mathrm{O}_{2}$.

Euryarchaeota commonly found at marine hydrothermal systems include the hyperthermophilic methanogens (Methanocaldococcus spp.), the hyperthermophilic $\mathrm{SO}_{4}{ }^{2-}$ reducing Archaeoglobales, and a variety of thermophilic fermentative Thermococcus species (Takai and Horikoshi, 1999; Takai et al., 2006a). While these are readily grown in the laboratory, their relative abundance in the environment has been shown to vary from site to site (Reysenbach et al., 2000; Takai et al., 2001; Hoek et al., 2003; Nercessian et al., 2003; McCliment et al., 2006). Several lineages often detected at vent sites around the globe have been classified as the deep-sea hydrothermal vent euryarchaeota (DHVE) groups (Takai and Horikoshi, 1999; Reysenbach et al., 2000; Takai et al., 2001; Hoek et al., 2003; Nercessian et al., 2003). Several subdivisions exist within this group but at least one lineage, the DHVE2, 
appears to be endemic to deep-sea vents. Little was known about this lineage until Moussard et al. (2006b) showed optimal activity and thermostability of a DNA polymerase belonging to this lineage which suggested a thermophilic lifestyle. Thermophily was confirmed when the first isolate was obtained in pure culture (Reysenbach et al., 2006). The organism, Aciduliprofundum boonei, is a heterotrophic thermoacidophile capable of fermenting peptides and reducing Fe and S. Isolation of this organism was significant because it is the first obligate acidophile isolated from a deep-sea vent and the first member of the DHVE2 lineage to be grown in the laboratory. Prior to this discovery, the absence of acidophiles from a deep-sea vent had always puzzled microbiologists as hydrothermal fluids are acidic and geochemists had predicted the presence of acidic microhabitats within sulfide chimneys (Von Damm, 1995; Tivey, 2004).

Inactive vent deposits

Hydrothermal fluid flow through individual deposits is temporary as subsurface flow paths constantly change and structures collapse. Inactive deposits are subjected to low temperature oxidative weathering in which the reduced sulfur moiety is converted to soluble $\mathrm{SO}_{4}{ }^{2-}$ and the metals, mostly $\mathrm{Fe}$, are converted to insoluble oxy-hydroxide crusts (Juniper and Tebo, 1995). Oxidation occurs abiotically as oxygenated seawater penetrates the rock but can also be mediated by S- and Fe-oxidizing bacteria (Edwards, 2004; Edwards et al., 2005). While microbial mediated sulfide weathering in terrestrial systems has been studied for decades, this area of research is in its infancy in the deep- 
sea (Edwards et al., 2003a; Edwards et al., 2003b; Rogers et al., 2003; Edwards, 2004;

Suzuki et al., 2004). Culturing studies have resulted in the isolation of several

psychrophilic, neutrophilic Fe-oxidizing bacteria belonging to the Alphaproteobacteria and Gammaproteobacteria from sulfide rocks collected along the Juan de Fuca Ridge (Edwards et al., 2003b). A follow up study with one of the Gammaproteobacteria isolates showed that the organism promoted the dissolution of native sulfide minerals under anaerobic conditions (Edwards, 2004). Although the mechanism of dissolution remains unclear, these studies illustrate that Fe-oxidizing bacteria are associated with extinct sulfide minerals on the seafloor and can actively promote the dissolution of these minerals at least in the laboratory.

Biotic and abiotic surfaces

Microbes are opportunistic organisms and will colonize any surface where growth substrates are provided. In areas influenced by hydrothermal fluids, this includes the sulfide deposits as described above and surfaces of invertebrate animals (reviewed in Van Dover, 2000). Some of these relationships are commensal as the host does not appear to gain an advantage by being colonized while others are symbiotic (episymbiosis) with both the host and microbes benefiting. An episymbiotic relationship is found on the polychaete worm Alvinella pompejana (Van Dover, 2000). Alvinella pompejana lives in tubes on the sides of black smoker chimneys where water temperatures can exceed $70^{\circ} \mathrm{C}$ (reviewed in Desbruyeres et al., 1998). It has a fully functional digestive system and appears to feed upon microbial mats inside of its tube as 
well on sulfide surfaces. The worm also houses diverse microbial communities on its dorsal surfaces including microaerophilic $\mathrm{H}_{2} \mathrm{~S}$-oxidizing members of the Epsilonproteobacteria. Although the exact nature of this relationship is unknown, it is thought that the bacteria may detoxify $\mathrm{H}_{2} \mathrm{~S}$ or provide nutritional supplement to the worm.

In addition to surfaces of vent animals, microbes often colonize rocks and sediments surrounding hydrothermal vents. These environments are primarily sustained by hydrothermal fluids flowing diffusely through the underlying porous sediments. The best studied and possibly most diverse microbial mat system found in marine hydrothermal environments is in the sediment-hosted Guaymas Basin. Microbes found here include thermophilic/mesophilic methanogens and methanotrophs (Dhillon et al., 2005), $\mathrm{SO}_{4}{ }^{2-}$ reducing Bacteria (Kallmeyer and Boetius, 2004), $\mathrm{H}_{2} \mathrm{~S}$-oxidizing Gammaproteobacteria (Nelson et al., 1989) and even spore forming Mn-oxidizers (Dick et al., 2006). Much of this diversity is fueled by the presence of overlying sediments which provides different combinations of organic/inorganic substrates typically not found in non-sediment hosted systems.

\section{Endosymbionts}

Several invertebrate animals form obligate symbiotic relationships in which the bacteria are hosted inside the animal cells. The best studied example is in the giant tube worm Riftia pachyptila (reviewed in Minic and Herve, 2004). As adults, Riftia completely lack a mouth, digestive system and anus and are sustained by 
chemoautotrophic $\mathrm{H}_{2} \mathrm{~S}$-oxidizing Gammaproteobacteria (Cavanaugh et al., 1981;

Felbeck, 1981; Jones, 1981; Minic and Herve, 2004). In this relationship, Riftia provides the bacteria with inorganic carbon, $\mathrm{O}_{2}, \mathrm{H}_{2} \mathrm{~S}$ and $\mathrm{NO}_{3}{ }^{-}$and, in turn is provided with organic carbon. Other invertebrate organisms like the giant clam Calyptogena magnifica and the mytilid mussels Bathymodiolus spp. also house $\mathrm{H}_{2} \mathrm{~S}$-oxidizing endosymbionts in their gill tissues (Van Dover, 2000). The symbiotic relationship between mussels and bacteria, however, is not obligate as they retain some of their filter feeding capabilities. In addition, certain species of Bathymodiolus have methanotrophic ( $\mathrm{CH}_{4}$-oxidizing) endosymbionts and even dual symbionts with both sulfur- and $\mathrm{CH}_{4}$ oxidizing bacteria.

\section{Hydrothermal plumes}

Upon reaching neutral buoyancy, hydrothermal vent plumes carrying elevated concentrations of $\mathrm{S}$, metals ( $\mathrm{Fe}$ and $\mathrm{Mn}$ ), $\mathrm{H}_{2}$, and $\mathrm{CH}_{4}$ extend hundreds of meters laterally into the water column. Not surprising, elevated biomass has been detected in plumes suggesting that these environments are areas of high productivity (reviewed in (Winn et al., 1995). Methane-oxidation has been measured in plume waters collected along the Juan de Fuca Ridge further supporting microbial activity in vent plumes (De Angelis et al., 1993). More recently, Sunamura and colleagues, (2004) used cultivation-independent techniques to assess the diversity of microbes in plumes over the Suiyo Seamount. Members of the Gammaproteobacteria and Epsilonproteobacteria were dominant in the plume waters and are likely using reduced 
sulfur compounds because of their close phylogenetic relationship with known sulfuroxidizers (Sunamura et al., 2004).

The first aerobic anoxygenic photosynthetic bacteria from the deep-sea were isolated from plumes (Yurkov and Beatty, 1998). These organisms belong to the Alphaproteobacteria and appear to supplement heterotrophic growth with photosynthesis under laboratory conditions. Their presence in deep-sea hydrothermal environments seems puzzling because of the lack of sunlight, but high-temperature fluids $\left(\approx 350^{\circ} \mathrm{C}\right)$ have been detected to emit photons capable of supporting facultative photosynthetic bacteria (Van Dover et al., 1996). Their role and significance in the environment, however, remains unknown.

\section{Scope of Dissertation}

Despite over thirty years of study, the abiotic controls on microbial diversity in marine hydrothermal environments remain largely unknown. In particular, how differences in the geologic settings of vent fields influence archaeal and bacterial communities of active hydrothermal vent deposits at the vent field scale is poorly understood. Differences in the geologic settings of vent fields can alter end-member fluid chemistry and are expected to influence microbial diversity as the fluids provide metabolic energy sources and set the physiological boundaries for colonizing microbes. Geologic factors that alter end-member fluid chemistry include differences in host-rock composition and inputs from a subducting plate along back-arc basins. For Chapter 2, I characterized the archaeal and bacterial communities of several deposits from the 
basalt-hosted Lucky Strike and ultramafic-hosted Rainbow vent fields along the MidAtlantic Ridge (MAR) using bar-coded pyrosequencing to determine if differences in host-rock composition influenced microbial diversity of active vent deposits. This same approach was extended in Chapter 3 to six vent fields along the Eastern Lau Spreading Center (ELSC) to compare the microbial communities from geochemically distinct systems located in a back-arc basin.

While advances in sequencing technologies have revolutionized microbial ecology, cultivation-based studies remain necessary in order to make ecological inferences about microorganisms in the environment. In deep-sea hydrothermal environments, numerous archaeal and bacterial lineages are represented by none or only a few cultivated organisms. Also, for many of the organisms in culture, we know very little about global distribution patterns and what factors may be influencing these patterns. With the recent isolation of the first obligate thermoacidophile from one of the previously uncultivated archaeal lineages (Reysenbach et al., 2006), it seems likely that some of the other uncultivated lineages may also be acidophilic. The overall objective for this section of my dissertation was to investigate thermoacidophily in geologically diverse hydrothermal environments by isolating novel thermoacidophiles (Chapter 4) and by conducting an in-depth survey of the distribution of the thermoacidophilic DHVE2 (Chapter 5). 


\section{Chapter 2: Microbial Community Structure of Hydrothermal Deposits from Geochemically Different Vent Fields Along the Mid-Atlantic Ridge.}

Flores, GE, Campbell, JH, Kirshtein, JD, Meneghin, J, Podar, M, Steinberg, JI, Seewald, JS, Tivey, MK, Voytek, MA, Yang, ZK and Reysenbach, A-L (2011). Environmental Microbiology, 13: no. doi: 10.1111/j.1462-2920.2011.02463.x.

\section{Abstract}

To evaluate the effects of local fluid geochemistry on microbial communities associated with active hydrothermal vent deposits, we examined the archaeal and bacterial communities of twelve samples collected from two very different vent fields; the basalt-hosted Lucky Strike $\left(37^{\circ} 17^{\prime} \mathrm{N}, 32^{\circ} 16.3^{\prime} \mathrm{W}\right.$, depth 1600 to $\left.1750 \mathrm{~m}\right)$ and the ultramafic-hosted Rainbow $\left(36^{\circ} 13^{\prime} \mathrm{N}, 33^{\circ} 54.1^{\prime} \mathrm{W}\right.$, depth 2270 to $\left.2330 \mathrm{~m}\right)$ vent fields along the Mid-Atlantic Ridge (MAR). Using multiplexed bar-coded pyrosequencing of the variable region 4 (V4) of the 16S rRNA genes, we show statistically significant differences between the archaeal and bacterial communities associated with the different vent fields. Quantitative polymerase chain reaction (qPCR) assays of the functional gene diagnostic for methanogenesis $(\mathrm{mcr} A)$, as well as geochemical modeling of sulfide deposits, support the pyrosequencing observations. Collectively, these results show that the less reduced, hydrogen-poor fluids of Lucky Strike limit the colonization of such strict anaerobes as methanogens, and allow for hyperthermophilic 
microaerophiles, like Aeropyrum. In contrast, the $\mathrm{H}_{2}$-rich reducing vent fluids of the ultramafic-influenced Rainbow vent field drive the prevalence of methanogens and other hydrogen-oxidizing thermophiles at this site. These results demonstrate that biogeographical patterns of hydrothermal vent microorganisms are shaped in part by large scale geological and geochemical processes.

\section{Introduction}

Deep-sea hydrothermal environments support highly productive biological communities comparable in total biomass production to the most prolific marine ecosystems (Sarrazin and Juniper, 1999). As the high temperature hydrothermal fluid mixes with cold oxygenated seawater, minerals precipitate to form vent mineral deposits (Tivey, 2007). These porous deposits are quickly colonized by a diversity of Archaea and Bacteria that harness the abundant geochemical energy available in the hydrothermal fluids (Page et al., 2008). One of the major processes controlling the chemical composition of hydrothermal fluids is the interaction of subsurface circulating seawater with surrounding igneous rocks (Von Damm, 1995). The majority of magmatically heated vent systems thus far studied are hosted by basaltic rocks and give rise to fluids rich in $\mathrm{H}_{2} \mathrm{~S}$ (Von Damm, 1995). However, along slow- and ultra-slow spreading ridges like the Mid-Atlantic Ridge (MAR), some hydrothermal systems include reactions with ultramafic rocks (peridotite), which have significant impacts on fluid chemistry. For example, due to serpentinization reactions, hydrothermal fluids can 
have elevated concentrations of $\mathrm{H}_{2}, \mathrm{Fe}$ and $\mathrm{CH}_{4}$, and lower levels of $\mathrm{H}_{2} \mathrm{~S}$ relative to basalt-hosted systems (Charlou et al., 2002) (Table 2.1).

Table 2.1. Range of physico-chemical characteristics of end-member hydrothermal fluids from different vent fields along the Mid-Atlantic Ridge. Fluids from $13^{\circ} \mathrm{N}$ along the East pacific Rise and seawater are added for comparison.

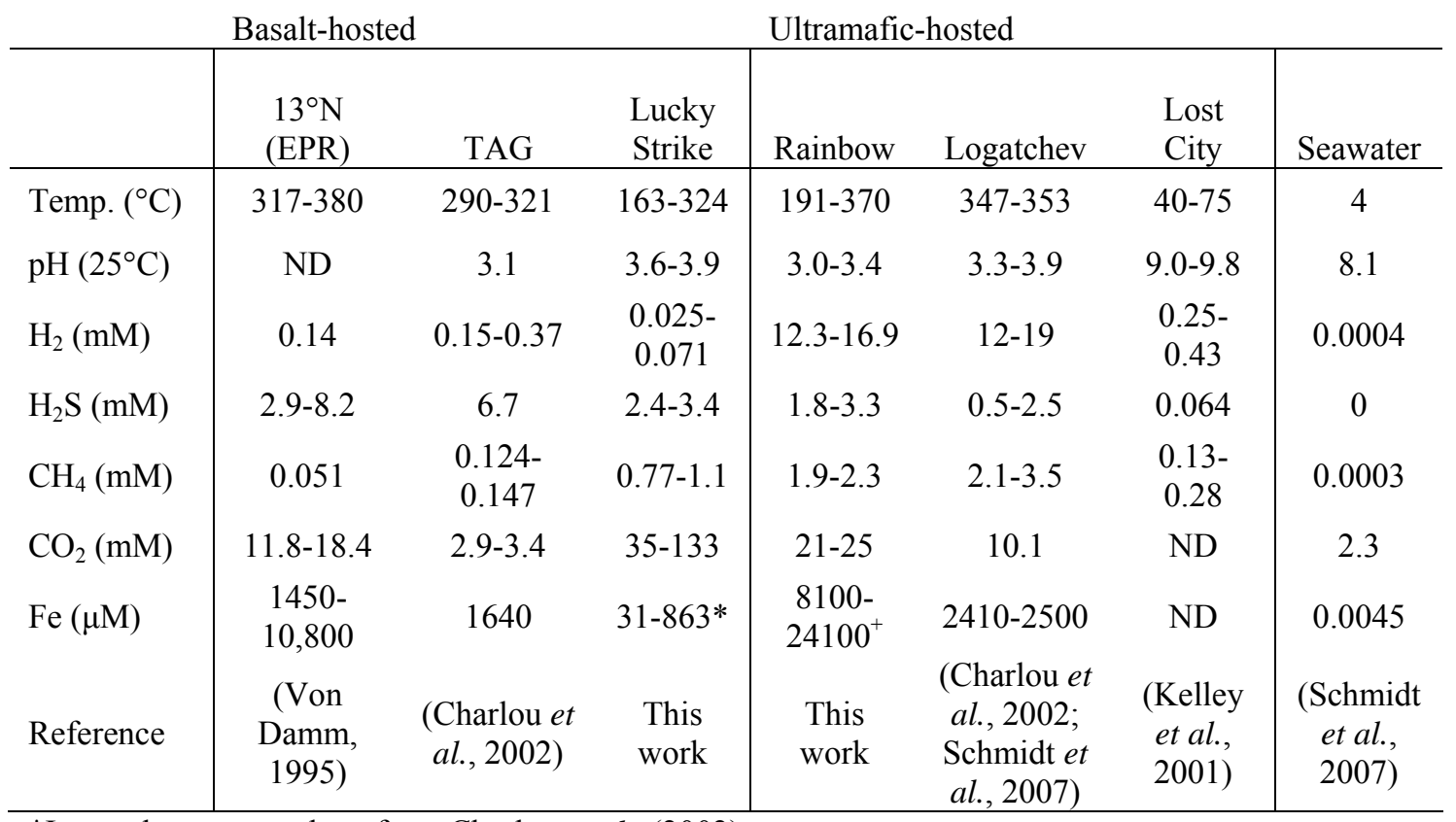

*Iron values reported are from Charlou et al., (2002).

+Iron values reported are from Seyfried et al., (2011).

Abbreviations: $\mathrm{TAG}=$ Trans-Atlantic Geotraverse, $\mathrm{EPR}=$ East Pacific Rise, $\mathrm{ND}=$ not determined .

While numerous molecular- and cultivation-based studies have been conducted to document the diversity of microorganisms associated with hydrothermal vent deposits, relatively few studies have explored the possible abiotic controls on microbial biogeography in these systems. Theoretically, the types and amounts of energy sources available in the hydrothermal fluids have been predicted to play a major role in determining the distribution patterns of deep-sea vent microorganisms (Shock et al., 1995; Shock and Holland, 2004; Tivey, 2004; Takai et al., 2006b; McCollom, 2007; 
Takai and Nakamura, 2010). Of the studies that have attempted to link hydrothermal fluid chemistry with microbial community composition, most have focused on single vent fields and have been hampered by inadequate sample number and/or sequencing depth (Takai et al., 2004b; Nakagawa et al., 2005d; Sogin et al., 2006; Huber et al., 2007; Perner et al., 2007; Takai et al., 2008; Nunoura and Takai, 2009; Opatkiewicz et al., 2009; Takai and Nakamura, 2010). Recently, Huber et al. (2010) overcame these limitations by employing next generation sequencing techniques to characterize the bacterial communities of diffuse fluid samples at 5 seamounts along the Mariana Arc. While the study revealed non-random distribution patterns of the dominant Epsilonproteobacteria, no correlations could be made between hydrothermal fluid chemistry and the observed patterns. Several factors, including the inability to detect fine-scale patterns with short 16S ribosomal RNA (rRNA) gene fragments from the hypervariable region 6 (V6), were suggested as possible reasons as to why community structure could not be correlated with fluid chemistry. As such, the impact of hydrothermal fluid chemistry on microbial community composition and/or structure remains largely unknown.

As the potential for direct coupling of geochemistry and biology is greatest at the interface where the hydrothermal fluids mix with seawater to produce mineral deposits, we hypothesized that the microbial communities associated with active vent deposits would be different in vent fields of contrasting chemistry. To address this question, we characterized the archaeal and bacterial communities of twelve deposits from two magmatically-heated hydrothermal systems; the ultramafic-hosted Rainbow 
$\left(36^{\circ} 13^{\prime} \mathrm{N}, 33^{\circ} 54.1^{\prime} \mathrm{W}\right.$, depth 2270 to $\left.2330 \mathrm{~m}\right)$ and the basalt-hosted Lucky Strike $\left(37^{\circ} 17^{\prime} \mathrm{N}, 32^{\circ} 16.3^{\prime} \mathrm{W}\right.$, depth 1600 to $1750 \mathrm{~m}$ ) vent fields along the MAR (Figure 2.1, Table 2.2). Due to the relatively close proximity of the two vent fields (approx. $180 \mathrm{~km}$ apart), the likelihood that any observed differences are due to a distance-decay relationship is minimized, and therefore provide model sites for assessing the impact geological processes controlling fluid chemistry has on microbial biogeography. Both vent fields have been fairly well characterized with respect to fluid chemistry (Langmuir et al., 1997; Von Damm et al., 1998; Charlou et al., 2002; Douville et al., 2002), geologic setting (Langmuir et al., 1997; Charlou et al., 2002; Douville et al., 2002; Humphris et al., 2002; Singh et al., 2006), deposit mineralogy (Rouxel et al., 2004b, a; Marques et al., 2006) and macrobiological communities (Desbruyeres et al., 2000; Desbruyeres et al., 2001).

The Rainbow vent field is located within ultramafic rocks on the western flank of a non-volcanic ridge at the intersection between the non-transform system faults and the ridge faults (Douville et al., 2002). The vent field is tectonically controlled and is composed of at least ten active chimneys that emit acidic, high-temperature fluids $\left(365^{\circ} \mathrm{C}\right)$ with relatively consistent end-member compositions indicative of a single source for the entire field (Charlou et al., 2002). Hydrothermal fluids from Rainbow are influenced by serpentinization reactions and are characterized by high gas, particularly $\mathrm{H}_{2}, \mathrm{CH}_{4}$ and $\mathrm{CO}$, and metal concentrations but relatively low $\mathrm{H}_{2} \mathrm{~S}$ concentrations (Table 2.1) (Charlou et al., 2002; Douville et al., 2002). Minerals 
present in these chimneys include pyrrhotite and isocubanite, indicating relatively reducing environments (Rouxel et al., 2004a).
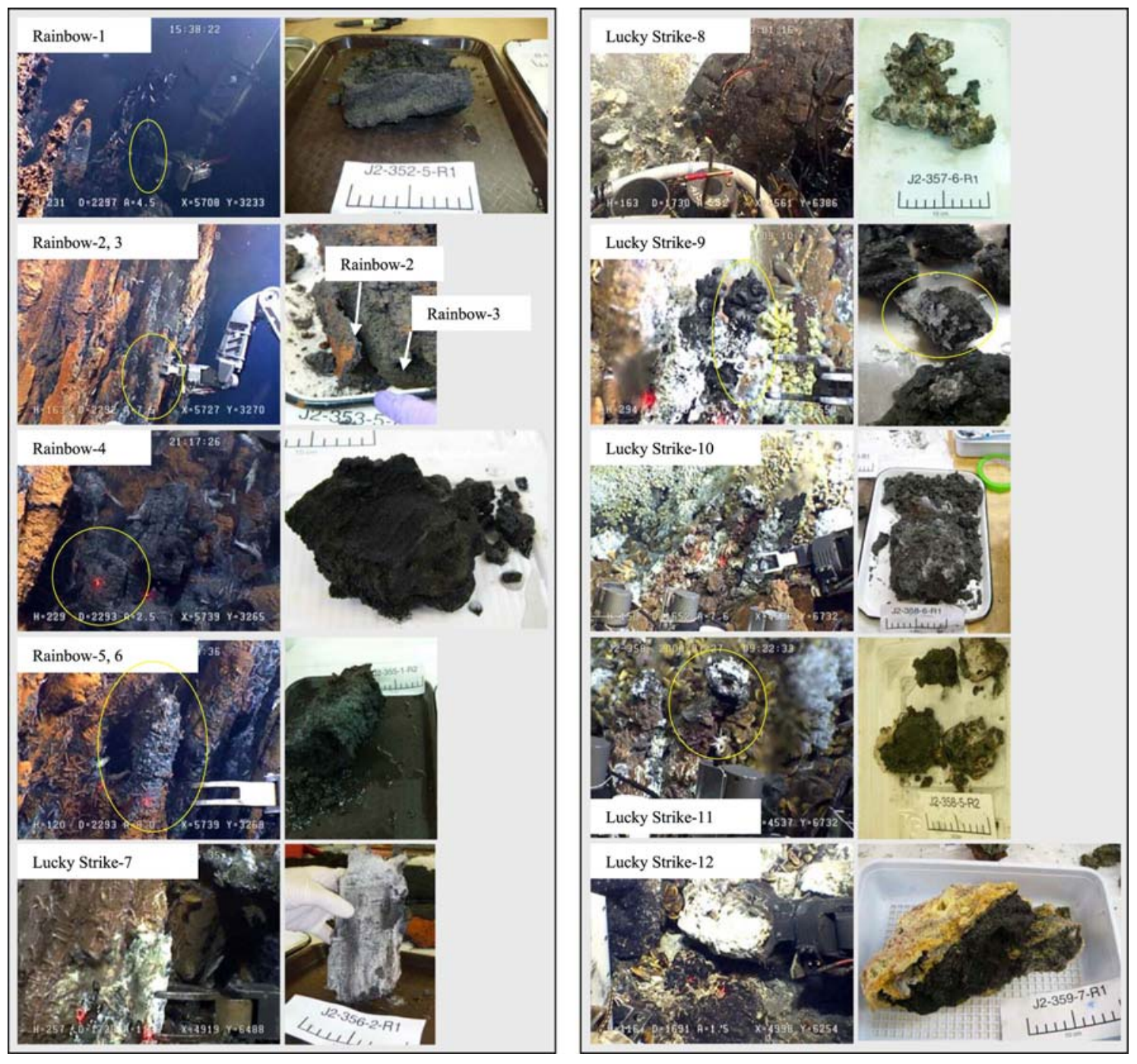

Figure 2.1. Photographs of hydrothermal vent samples collected from the Rainbow and Lucky Strike vent fields. Yellow circles indicate which chimney/section was used for sampling. 
Table 2.2. Hydrothermal vent deposits used to characterize the microbial communities from the Rainbow (Rb) and Lucky Strike (LS) vent fields.

\begin{tabular}{|c|c|c|c|c|c|}
\hline $\begin{array}{l}\text { Sample } \\
\text { name }\end{array}$ & $\begin{array}{l}\text { Latitude / } \\
\text { Longitude }\end{array}$ & Depth (m) & Deposit type & $\begin{array}{c}\text { \# of Archaeal } \\
\text { pyrotags }^{1}\end{array}$ & $\begin{array}{c}\# \text { of Bacterial } \\
\text { pyrotags }^{2}\end{array}$ \\
\hline $\mathrm{Rb}-1$ & $\begin{array}{l}36^{\circ} 13.7487^{\prime} \mathrm{N} / \\
33^{\circ} 54.1915^{\prime} \mathrm{W}\end{array}$ & 2297 & Chimney & 11037 & 9211 \\
\hline $\mathrm{Rb}-2^{+}$ & $\begin{array}{l}36^{\circ} 13.7688^{\prime} \mathrm{N} / \\
33^{\circ} 54.1796^{\prime} \mathrm{W}\end{array}$ & 2292 & Chimney & 5210 & 4476 \\
\hline $\mathrm{Rb}-3$ & $\begin{array}{l}36^{\circ} 13.7688^{\prime} \mathrm{N} / \\
33^{\circ} 54.1796^{\prime} \mathrm{W}\end{array}$ & 2292 & Chimney & 1280 & 8080 \\
\hline $\mathrm{Rb}-4$ & $\begin{array}{l}36^{\circ} 13.7661^{\prime} \mathrm{N} / \\
33^{\circ} 54.1664^{\prime} \mathrm{W}\end{array}$ & 2293 & Chimney & 4370 & 9622 \\
\hline $\mathrm{Rb}-5^{+}$ & $\begin{array}{l}36^{\circ} 13.7672^{\prime} \mathrm{N} / \\
33^{\circ} 54.1714^{\prime} \mathrm{W}\end{array}$ & 2293 & Chimney & 618 & 10539 \\
\hline $\mathrm{Rb}-6^{+}$ & $\begin{array}{l}36^{\circ} 13.7672^{\prime} \mathrm{N} / \\
33^{\circ} 54.1714^{\prime} \mathrm{W}\end{array}$ & 2293 & Chimney & 6037 & 8024 \\
\hline $\mathrm{LS}-7^{+}$ & $\begin{array}{l}37^{\circ} 17.5075^{\prime} \mathrm{N} / \\
32^{\circ} 16.6743^{\prime} \mathrm{W}\end{array}$ & 1732 & Chimney & 5565 & 8931 \\
\hline LS-8 & $\begin{array}{l}37^{\circ} 17.4528^{\prime} \mathrm{N} / \\
32^{\circ} 16.9161^{\prime} \mathrm{W}\end{array}$ & 1730 & Flange & 1123 & 7368 \\
\hline LS-9 & $\begin{array}{l}37^{\circ} 17.6395^{\prime} \mathrm{N} / \\
32^{\circ} 16.9329^{\prime} \mathrm{W}\end{array}$ & 1652 & Chimney & 1865 & 7365 \\
\hline LS-10 & $\begin{array}{l}37^{\circ} 17.5410^{\prime} \mathrm{N} / \\
32^{\circ} 16.8795^{\prime} \mathrm{W}\end{array}$ & 1729 & Chimney & 1540 & 5424 \\
\hline LS-11 & $\begin{array}{l}37^{\circ} 17.6487^{\prime} \mathrm{N} / \\
32^{\circ} 16.9046^{\prime} \mathrm{W}\end{array}$ & 1660 & Chimney & 5128 & 8646 \\
\hline LS-12 & $\begin{array}{l}37^{\circ} 17.3787^{\prime} \mathrm{N} / \\
32^{\circ} 16.6212^{\prime} \mathrm{W}\end{array}$ & 1690 & Flange & 1422 & 3921 \\
\hline
\end{tabular}

${ }^{+}$denotes samples for which partial 16S rRNA gene clone libraries were generated.

${ }^{1}$ Average read length $=247$ nucleotides

${ }^{2}$ Average read length $=207$ nucleotides

The Lucky Strike vent field is located at the summit of the Lucky Strike seamount along the MAR near a young, solidified lava lake and is one of the largest vent fields along the MAR (Langmuir et al., 1997; Humphris et al., 2002).

Hydrothermal activity here has been episodic but ongoing for hundreds to thousands of years (Humphris et al., 2002). The fluids from Lucky Strike originate from reactions 
with relatively oxic, and previously altered basalt, and are somewhat unique for a basalt-hosted system with respect to the relatively high $\mathrm{pH}$ and low $\mathrm{Fe}$, manganese (Mn), lithium (Li) and zinc (Zn) concentrations (Table 2.1) (Von Damm et al., 1998). Minerals present in chimneys and flanges include pyrite, marcasite, chalcopyrite and sphalerite, indicative of relatively more oxidizing conditions than at the Rainbow vent field (Langmuir et al., 1997; Rouxel et al., 2004b). There is also evidence that fluids from Lucky Strike may have two sources as fluids from the northern segment are systematically different than those from the south. Unlike fluids from Rainbow, the predominant gas in Lucky Strike fluids is $\mathrm{CO}_{2}$ with $\mathrm{H}_{2}$ two- to three-orders of magnitude less in concentration (Von Damm et al., 1998; Charlou et al., 2002). Such dramatic differences in $\mathrm{H}_{2}$ concentrations are likely to be a strong force in structuring hydrothermal vent microbial communities as has been previously predicted (Shock et al., 1995; Shock and Holland, 2004; Takai et al., 2006b; McCollom, 2007; Takai and Nakamura, 2010) since many chemosynthetic primary producers utilize $\mathrm{H}_{2}$ as an energy source.

\section{Results and Discussion}

\section{Alpha- and beta-diversity}

Because of the limitations of using the V6 region of the 16S rRNA gene in multiplexed bar-coded pyrosequencing (Claesson et al., 2009; Huber et al., 2010; Schloss, 2010), we targeted the V4 region to characterize the archaeal and bacterial 
communities associated with hydrothermal deposits. Using this approach, we generated 45,195 and 91,607 high-quality archaeal (average 3,766 sequences/sample, 247-249 nt length) and bacterial (average 7,634 sequences/sample, 207-208 nt length) sequences, respectively (Table 2.2). Pyrosequencing amplicons were aligned and clustered using the Ribosomal Database Projects (RDP) pyrosequencing and the SLP/PW-AL pipelines at operational taxonomic unit (OTU) definitions of $95 \%$ and $97 \%$ sequence similarity, respectively (Cole et al., 2009; Huse et al., 2010). Alpha-diversity assessments (OTU richness, Chao1 index and rarefaction analysis) revealed comparable results with both alignment/clustering approaches providing confidence that overestimates of diversity were minimized (Figure 2.2, Table 2.3). Overall, bacterial diversity was greater than archaeal diversity in all samples. Furthermore, several of the archaeal rarefaction curves are near-asymptotic, indicating that we have nearly completely sampled the archaeal V4 diversity of these samples (Figure 2.2A). 


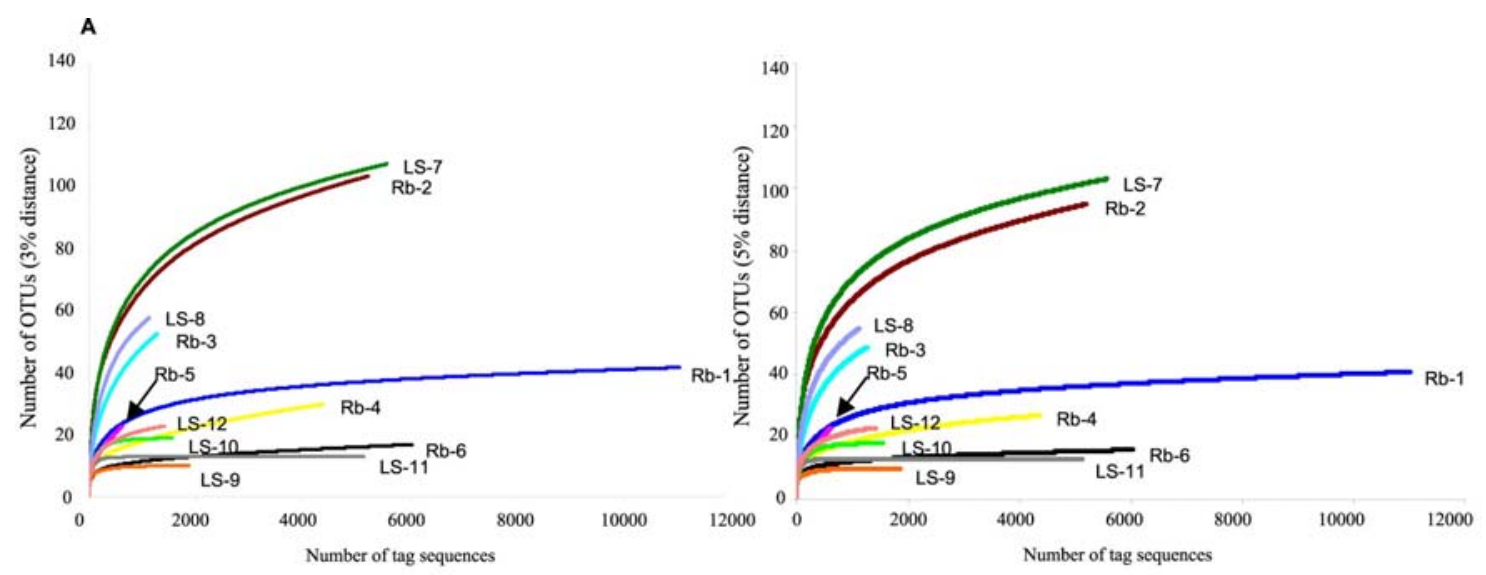

B
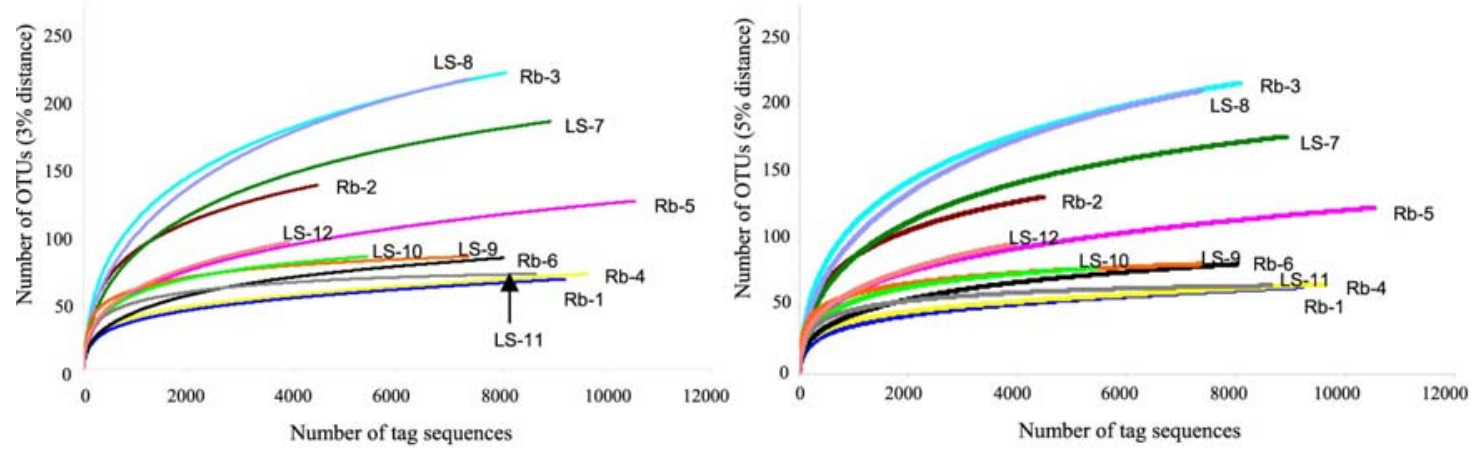

Figure 2.2. Rarefaction analysis illustrates the greater diversity observed in the bacterial communities of twelve hydrothermal deposit samples collected from the Rainbow and Lucky Strike vent fields. A, Archaeal rarefaction curves at two sequence similarity levels $(97 \%$ and $95 \%$ ) using two different alignment/clustering methods. Note the near-asymptotic appearance of several curves suggesting nearly complete sampling of the V4 sequences. B, Bacterial rarefaction curves. $\mathrm{Rb}=$ Rainbow, $\mathrm{LS}=$ Lucky Strike. 
Table 2.3. Comparison of OTU richness and Chaol diversity estimates generated from two different clustering methods for archaeal and bacterial communities of hydrothermal vent deposits collected along the Mid-Atlantic Ridge.

\begin{tabular}{|c|c|c|c|c|c|c|c|c|}
\hline \multirow[b]{3}{*}{ Sample } & \multicolumn{4}{|c|}{ Archaea } & \multicolumn{4}{|c|}{ Bacteria } \\
\hline & \multicolumn{2}{|c|}{$\begin{array}{l}\text { 97\% OTU } \\
\text { definition }^{+}\end{array}$} & \multicolumn{2}{|c|}{$\begin{array}{l}\text { 95\% OTU } \\
\text { definition }^{\#}\end{array}$} & \multicolumn{2}{|c|}{$\begin{array}{l}97 \% \text { OTU } \\
\text { definition }^{+}\end{array}$} & \multicolumn{2}{|c|}{$\begin{array}{l}\text { 95\% OTU } \\
\text { definition }\end{array}$} \\
\hline & OTUs & Chaol* & OTUs & Chao1* & OTUs & Chaol* & OTUs & Chaol* \\
\hline $\mathrm{Rb}-1$ & 42 & $44-96$ & 41 & $43-95$ & 68 & $77-150$ & 65 & $73-146$ \\
\hline $\mathrm{Rb}-2$ & 104 & $115-185$ & 95 & 106-191 & 139 & $151-204$ & 132 & 141-185 \\
\hline $\mathrm{Rb}-3$ & 53 & 58-106 & 49 & $51-81$ & 224 & $251-324$ & 217 & $240-305$ \\
\hline $\mathrm{Rb}-4$ & 30 & $33-74$ & 27 & $28-45$ & 72 & $95-281$ & 67 & $80-206$ \\
\hline $\mathrm{Rb}-5$ & 23 & $27-136$ & 23 & $45-220$ & 127 & $146-226$ & 124 & $142-224$ \\
\hline $\mathrm{Rb}-6$ & 17 & $19-70$ & 16 & $16-42$ & 84 & $97-187$ & 82 & $92-170$ \\
\hline LS-7 & 108 & 119-197 & 103 & $111-174$ & 187 & $204-261$ & 177 & $192-245$ \\
\hline LS-8 & 58 & $63-114$ & 55 & $60-115$ & 219 & $247-316$ & 211 & $232-290$ \\
\hline LS-9 & 10 & - & 10 & - & 85 & $87-117$ & 82 & 84-114 \\
\hline LS-10 & 19 & - & 18 & - & 85 & $90-134$ & 79 & $82-115$ \\
\hline LS-11 & 13 & - & 13 & - & 72 & $72-87$ & 66 & $66-80$ \\
\hline LS-12 & 23 & $23-35$ & 23 & $23-31$ & 96 & $108-167$ & 97 & $107-160$ \\
\hline
\end{tabular}

Dashes indicate samples for which the Chaol estimator could not be calculated for due to the lack of singleton/doubleton OTUs. $\mathrm{Rb}=$ Rainbow, $\mathrm{LS}=$ Lucky Strike

${ }^{+}$Clusters generated using the SLP/PW-AL pipeline Huse et al., (2010).

\#Clusters generated using the RDP furthest-neighbor clustering method.

*Ranges of Chao 1 indices include $95 \%$ confidence intervals.

Differences in overall community composition between vent fields (betadiversity) were assessed using both OTU-based metrics (Bray-Curtis, Sørensen) and the phylogeny-based metric, UniFrac (Lozupone et al., 2006; Hamady et al., 2010).

UniFrac distances were calculated to account for abundances of individual taxa (weighted) or based solely on presence/absence (unweighted). Non-metric multidimensional scaling (MDS) plots built using all metrics revealed that the communities from the two vent fields were distinct (Figure 2.3A and B, Figure 2.4A F). Statistically significant patterns, as determined by ANOSIM (Primer v6), were 
observed in 7 of the 8 analyses with the sole exception being the bacterial weighted UniFrac distances (Figure 2.4E). It is likely that the dominance of closely related Epsilonproteobacteria in the bacterial data mask the significant differences observed using the unweighted UniFrac distances, although the bacterial communities were significantly different in both weighted (Bray-Curtis) and unweighted (Sørensen) OTUbased analyses. Moreover, we found that the archaeal and bacterial community composition varied significantly less within vent fields than between vent fields and hence, community composition was more similar within than between vent fields (Figure 2.3C, Figure 2.4G, $\mathrm{H}$ and I). This suggests that the geochemical differences between the two vent fields are a stronger force in structuring microbial communities than any within vent field force. Together, these results clearly show that the microbial communities are different between the Rainbow and Lucky Strike vent fields.

\section{Taxonomy}

While beta-diversity metrics provide insights into overall community differences, assigning taxonomic identities to sequences allows for determining how these communities differ taxonomically and possibly functionally. To achieve this, we used the RDP-classifier (Wang et al., 2007) set at a bootstrap value of 50\% (Claesson et al., 2009) to classify representative sequences of each OTU defined using the RDP-95\% clusters. Manual classifications using ARB (Ludwig et al., 2004) and BLAST were also done for many unclassified OTUs as known lineages (e.g., Aciduliprofundales) were not classified by the RDP-classifier. 

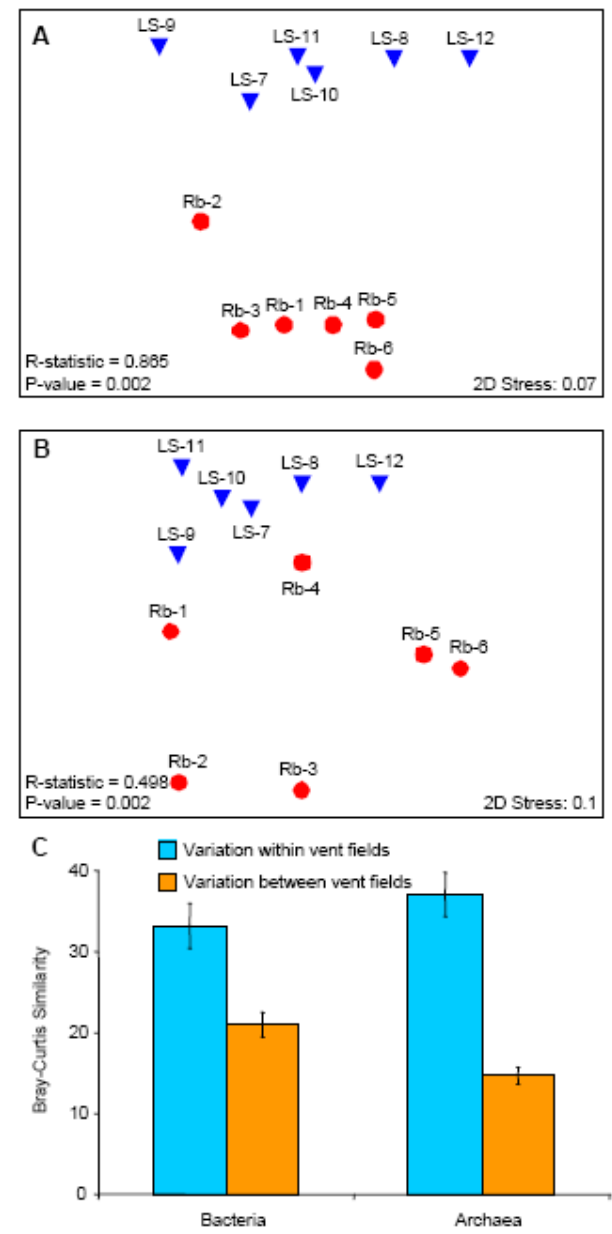

Figure 2.3. 16S rRNA gene surveys reveal partitioning of the archaeal and bacterial communities between the ultramafic-hosted Rainbow (red) and basalt-hosted Lucky Strike (blue) vent fields along the Mid-Atlantic Ridge. Communities clustered using NMDS of the Bray-Curtis similarities for archaeal (A) and bacterial (B) communities. Each point represents an individual vent sample. Results of ANOSIM analysis showing that the observed patterns are significant are presented in the bottom left corner of each plot. C, Average Bray-Curtis similarity within and between vent fields. Average distances were significantly different for both archaeal and bacterial communities as determined by one-tailed $t$-tests $(\mathrm{P}<0.001)$. Error bars indicate the standard error of the mean (SEM). 

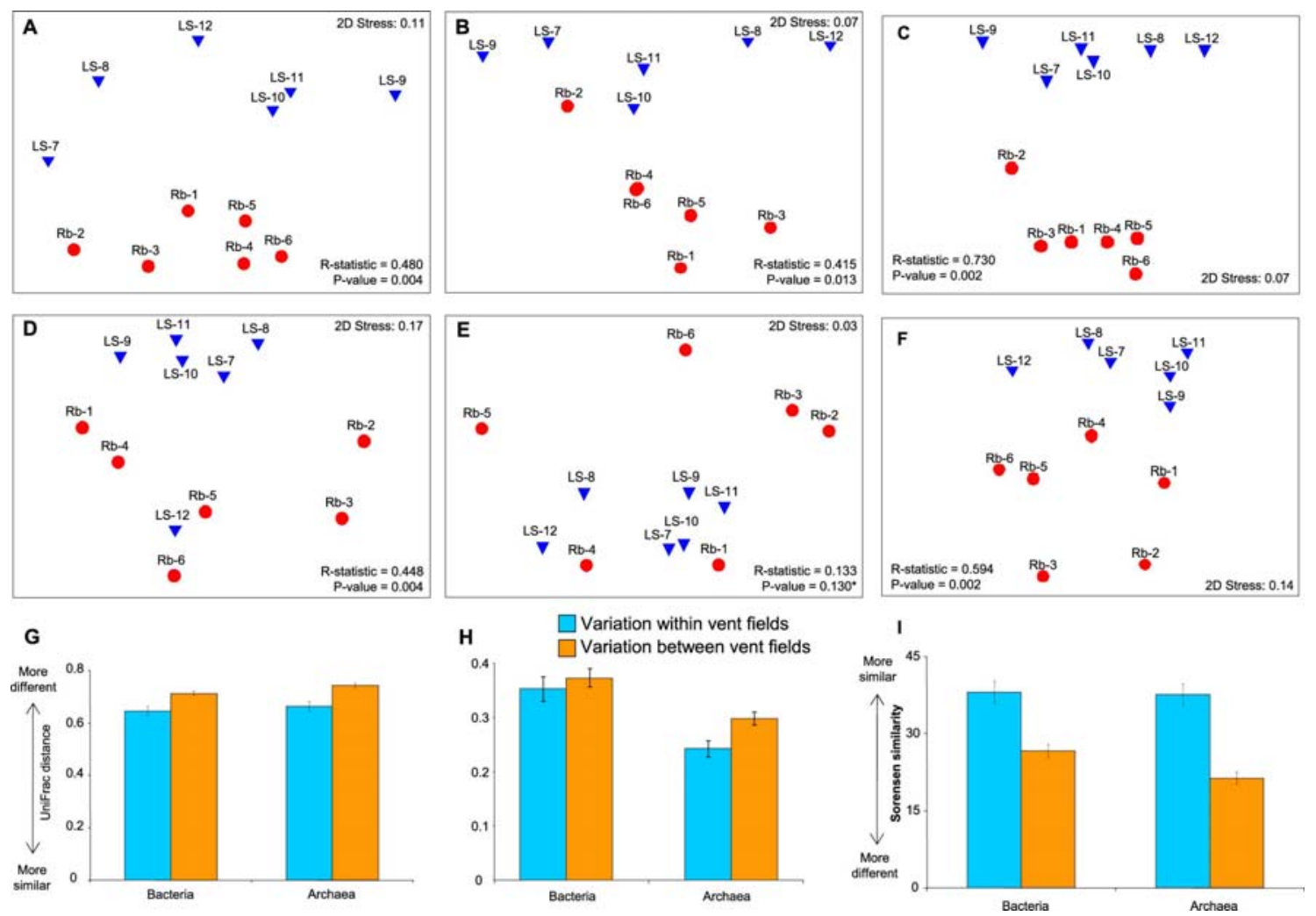

Figure 2.4. 16S rRNA gene surveys reveal partitioning of the archaeal and bacterial communities between the ultramafic hosted Rainbow (red) and basalt-hosted Lucky Strike (blue) vent fields along the Mid-Atlantic Ridge. Communities clustered using MDS of the unweighted (A and D) and weighted (B and $\mathbf{E})$ UniFrac distances for archaeal (A, B) and bacterial $(\mathbf{D}, \mathbf{E})$ communities. Sorensen similarity values for archaeal $(\mathbf{C})$ and bacterial $(\mathbf{F})$ communities also clustered by vent site. Each point represents an individual vent sample. Results of ANOSIM analysis showing that the observed patterns are significant are presented in the bottom right or left corner of each plot. (G) Average unweighted and weighted (H) UniFrac distance within and between vent fields. Average distances were significantly different for archaeal weighted $(P<0.01)$ and unweighted $(P<0.001)$, and bacterial unweighted $(P<0.001)$ communities as determined by one-tailed $t$-tests. Sorensen similarities were also significantly different $(\mathbf{I})$ for both bacteria $(P<0.001)$ and archaea $(P<0.001)$. Error bars indicate the standard error of the mean (SEM). 
Archaea

Overall, the archaeal lineages observed at both vent fields were typical for this environment and likely represent the core archaeal microbiome. Archaeal families shared between all vent samples include the thermophilic Desulfurococcaceae, Thermococcaceae and Thermofilaceae (Figure 2.5A). Other thermophilic lineages shared by most samples include the mixotrophic Archaeoglobaceae, the acidophilic fermentative Aciduliprofundales (DHVE2), and the Nanoarchaea (Takai and Horikoshi, 1999; Boone et al., 2001; Huber et al., 2002a; Reysenbach et al., 2006; Reysenbach and Flores, 2008). Several novel lineages with no known isolates in culture were also observed. For example, three OTUs ("Unclassified Euryarchaeota A") were found in all but three samples. Sequences of these OTUs are related to clones found in other deep-sea vent environments (>94\% similarity) (Moussard et al., 2006a). Homologous sequences were also identified in the 16S rRNA gene clone libraries generated for this study (data not shown).

The most striking difference between the two vent fields was the absence of known methanogens (Methanococcaceae and Methanocaldococcaceae) at Lucky Strike (Figure 2.5A). This is notable because methanogens are common inhabitants of most vent fields (Takai et al., 2006a), although a few single chimney surveys with limited sequencing depth have also failed to detect methanogens at other vent fields (Takai et al., 2001; Hoek et al., 2003; Kormas et al., 2006; Zhou et al., 2009). Nevertheless, this is the first report with this level of sampling and sequencing depth (12 samples, 45,195 sequences) that shows their absence at the vent field scale. The lack of detectable 
methanogens was confirmed by quantitative polymerase chain reaction (qPCR) assays of a functional gene diagnostic for methanogenesis ( $\mathrm{mcr} A)$ in 18 vent deposits from Lucky Strike (Figure 2.6). Furthermore, methanogens were not detected in 16S rRNA gene clone libraries constructed from the most diverse of the Lucky Strike samples (data not shown). The absence of methanogens at Lucky Strike in conjunction with their abundance at Rainbow is in agreement with theoretical calculations of free-energy yield for thermophilic hydrogenotrophic methanogenesis based on $\mathrm{H}_{2}$ concentrations as previously reported (McCollom, 2007; Takai and Nakamura, 2010). Other notable differences in the archaeal communities between vent fields were observed within the Desulfurococcaceae at the genus level. For example, the obligate anaerobe Staphylothermus, was prevalent in Rainbow deposits while the microaerophilic Aeropyrum was prevalent in Lucky Strike deposits (Figure 2.5B).

SIMPER analysis (Primer v6) (Clarke and Gorley, 2006) was used to determine which archaeal genera were most responsible for the differences observed between sites (Table 2.4). The top four of these indicator, or "discriminating" OTUs were two methanogens (Methanocaldococcus and Methanothermococcus) as well as Staphylothermus and Aeropyrum, which clearly points to these genera driving the differences observed between the two sites. 


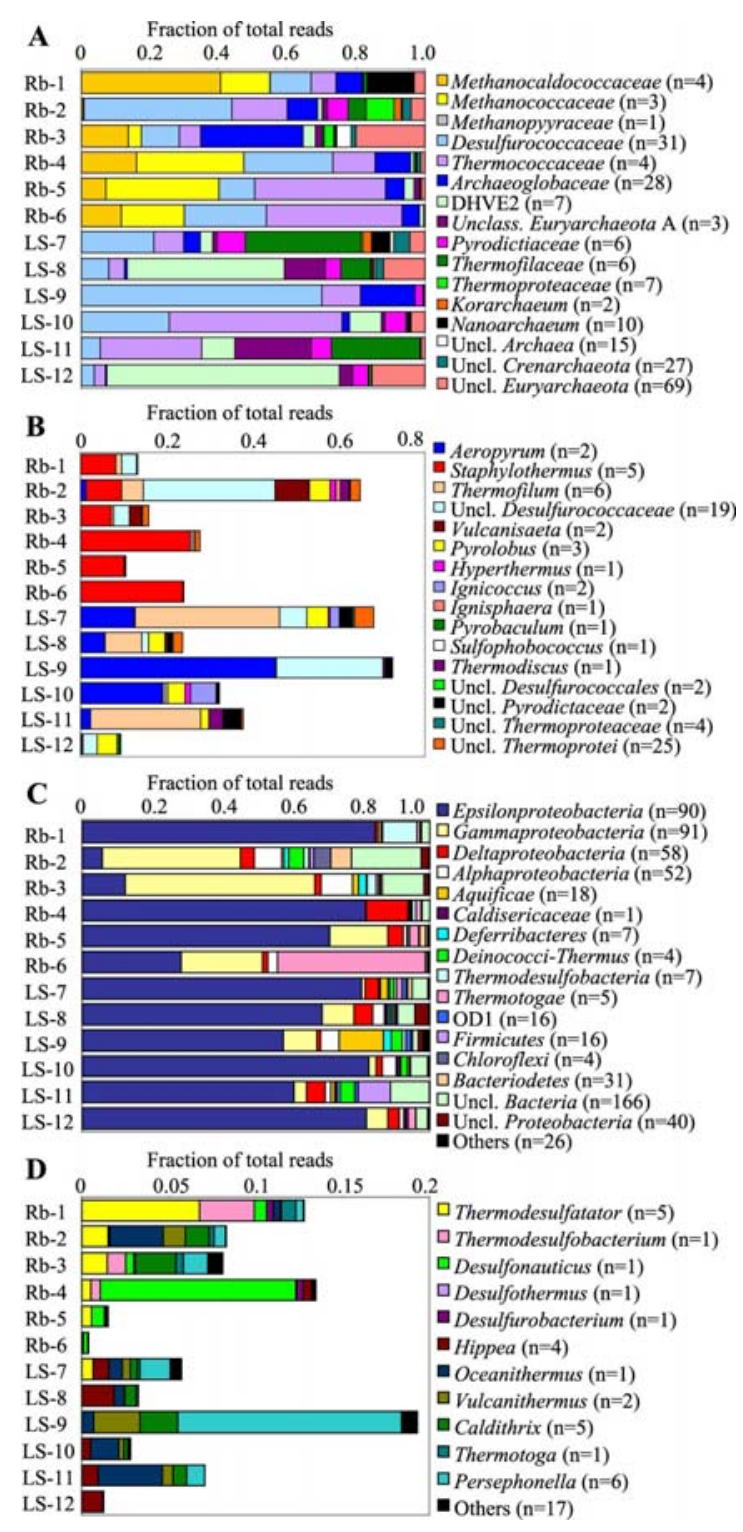

Figure 2.5. Comparison of taxonomic variation in the archaeal and bacterial communities of Rainbow and Lucky Strike hydrothermal vent deposits. A, Relative abundances of archaeal families observed in each vent deposit. Note the absence of methanogens in all Lucky Strike samples. B, Relative abundances of crenarchaeal genera observed in each vent deposit. C, Relative abundances of bacterial orders observed in each vent deposit. D, Relative abundances of less abundant thermophilic genera observed in each vent deposit. Note that the abundant, unclassified Thermotogae lineages shown in figure $\mathbf{C}$ have been omitted in $\mathbf{D}$ to allow for visualization of low abundance genera. Numbers in parentheses following taxonomic classifications indicate the number of OTUs classified to that particular group. $\mathrm{Rb}=$ Rainbow, LS = Lucky Strike. 


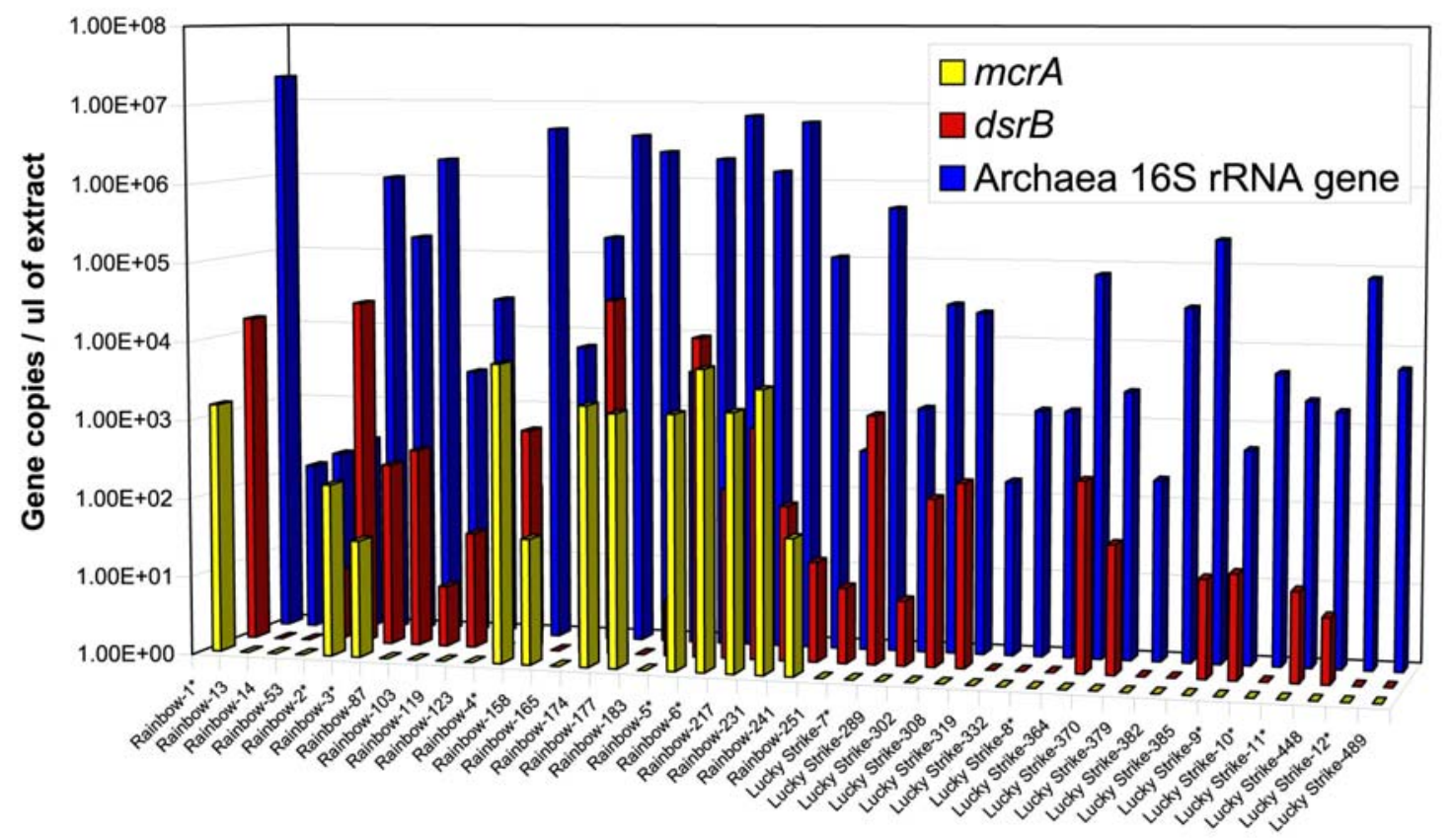

Figure 2.6. Quantitative polymerase chain reaction assays targeting the gene diagnostic for methanogenesis ( $m c r A)$ confirms the absence of methanogens at Lucky Strike. The archaeal $16 \mathrm{~S}$ rRNA and the dissimilatory sulfide reductase $(d s r \mathrm{~B})$ genes were also targeted in order to verify the presence of amplifiable DNA in each sample. All gene copy numbers were normalized/g of chimney material extracted. Amplified mcrA and dsrB products were verified by cloning and sequencing of the gene (not shown). Asterisks denote samples surveyed by 454pyrosequencing. 
Table 2.4. SIMPER analysis was used to identify archaeal genera responsible for the dissimilarity observed in the communities of Rainbow and Lucky Strike vent deposits.

\begin{tabular}{|c|c|c|c|c|c|}
\hline Genus classification & ID \# & $\begin{array}{c}\text { Rainbow } \\
\text { Ave. Abun* }\end{array}$ & $\begin{array}{l}\text { Lucky } \\
\text { Strike Ave. } \\
\text { Abun* }\end{array}$ & $\begin{array}{c}\text { Dissimilarity } \\
\text { contribution } \\
(\%)\end{array}$ & $\begin{array}{c}\text { Cumulative } \\
\text { dissimilarity } \\
(\%)\end{array}$ \\
\hline Methanocaldococcus & 10 & 3.54 & 0 & 6.70 & 6.70 \\
\hline Staphylothermus & 2 & 3.59 & 0.11 & 6.53 & 13.24 \\
\hline Methanothermococcus & 1 & 3.33 & 0 & 6.40 & 19.63 \\
\hline Aeropyrum & 1679 & 0.11 & 3.09 & 5.56 & 25.20 \\
\hline DHVE2_Cultured & 22 & 0.91 & 2.88 & 4.44 & 29.64 \\
\hline Thermococcus & 819 & 1.96 & 3.42 & 4.30 & 33.94 \\
\hline Thermococcus & 3 & 2.26 & 0.81 & 4.29 & 38.23 \\
\hline Archaeoglobus & 76 & 2.44 & 0.14 & 4.13 & 42.35 \\
\hline DHVE2_Group_1 & 396 & 0.02 & 2.2 & 3.98 & 46.34 \\
\hline Thermofilum & 796 & 0.69 & 2.55 & 3.59 & 49.93 \\
\hline Pyrolobus & 1181 & 0.17 & 1.71 & 2.89 & 52.82 \\
\hline $\begin{array}{l}\text { Unclass. } \\
\text { Euryarchaeota_A }\end{array}$ & 1474 & 0.45 & 1.63 & 2.78 & 55.61 \\
\hline Thermococcus & 15 & 1.76 & 0.61 & 2.76 & 58.37 \\
\hline Methanococcus & 9 & 1.35 & 0 & 2.59 & 60.96 \\
\hline $\begin{array}{l}\text { Unclass. } \\
\text { Desulfurococcaceae }\end{array}$ & 972 & 1.08 & 1.13 & 2.52 & 63.48 \\
\hline DHVE2_Cultured & 3077 & 0 & 1.26 & 2.22 & 65.70 \\
\hline Unclass. Pyrodictaceae & 1726 & 0 & 1.12 & 2.01 & 67.71 \\
\hline Archaeoglobus & 0 & 1.13 & 0.48 & 1.85 & 69.55 \\
\hline Aeropyrum & 1681 & 0.18 & 1.02 & 1.75 & 71.30 \\
\hline $\begin{array}{l}\text { Unclass. } \\
\text { Archaeoglobaceae }\end{array}$ & 1684 & 0 & 0.9 & 1.72 & 73.02 \\
\hline
\end{tabular}

*Calculated by standardizing abundances by percentage of each sample library, taking the square root and then averaging by vent field.

Models based on the geochemical characteristics of end-member fluids and their mixing styles in porous, permeable vent deposits (i.e., diffusion and advection across deposits walls bound on one side by vent fluid and the other by seawater) predict wide oxidizing zones in exterior portions of Lucky Strike deposits and an absence of any oxidizing zone in exterior portions of Rainbow deposits (Figure 2.7A - C, Figure 2.8A 
- C). The calculations were carried out as described in Tivey (2004), considering diffusion and advection of aqueous species across a porous (porosity 0.5 ) chimney wall bound on one side by cold seawater, and on the other by the appropriate vent fluid. Compositions of vent fluids from the Sintra and Marker 6 vents at Lucky Strike (Charlou et al., 2000), and from the Flores5 vent at Rainbow (Charlou et al., 2002), were used in calculations. Concentrations of relevant aqueous species as a function of position within the chimney wall are shown in Figure 2.7.

The very large differences in redox conditions for mid to exterior layers (those at less than $\sim 120^{\circ} \mathrm{C}$ ) are a result of the extremes in aqueous $\mathrm{H}_{2}$ concentrations in the different end-member fluids (16 mM at Rainbow versus $3.3 \mathrm{uM}$ (Sintra) and $77 \mathrm{uM}$ (Marker 6) at Lucky Strike). Even with advection of vent fluid outward through the chimney wall, conditions of pore fluids within a chimney at the Sintra vent, Lucky Strike, would be relatively oxidizing at all temperatures up to $177^{\circ} \mathrm{C}$ (Figure 2.7A). Other vents at Lucky Strike have higher concentrations of aqueous $\mathrm{H}_{2}$ in end-member fluids, but still, conditions within a chimney at the Marker 6 vent, would be relatively oxidizing at temperatures up to $60^{\circ} \mathrm{C}$ (Figure $2.7 \mathrm{~B}$ ). These "relatively oxidizing zones" are zones where the free energy of the reactions for oxidation of sulfide and for methanotrophy are less than zero and thus favorable, while the free energy for the reactions for reduction of sulfate and for methanogenesis are greater than zero, and thus not favorable. Metabolic energies that would be produced from the favorable reactions at Lucky Strike (e.g., sulfide-oxidation and methanotrophy) are comparable to those calculated for chimneys from other vent fields considering diffusion and advection 
across chimney walls (Tivey, 2004), and mixing of seawater and vent fluid (McCollom and Shock, 1997; Takai and Nakamura, 2010). Metabolic energy from methanogenesis in a Lucky Strike chimney at Marker 6 vent, in zones of the chimney that are at temperatures greater than $60^{\circ} \mathrm{C}$, would be less than half of that from sulfate-reduction.
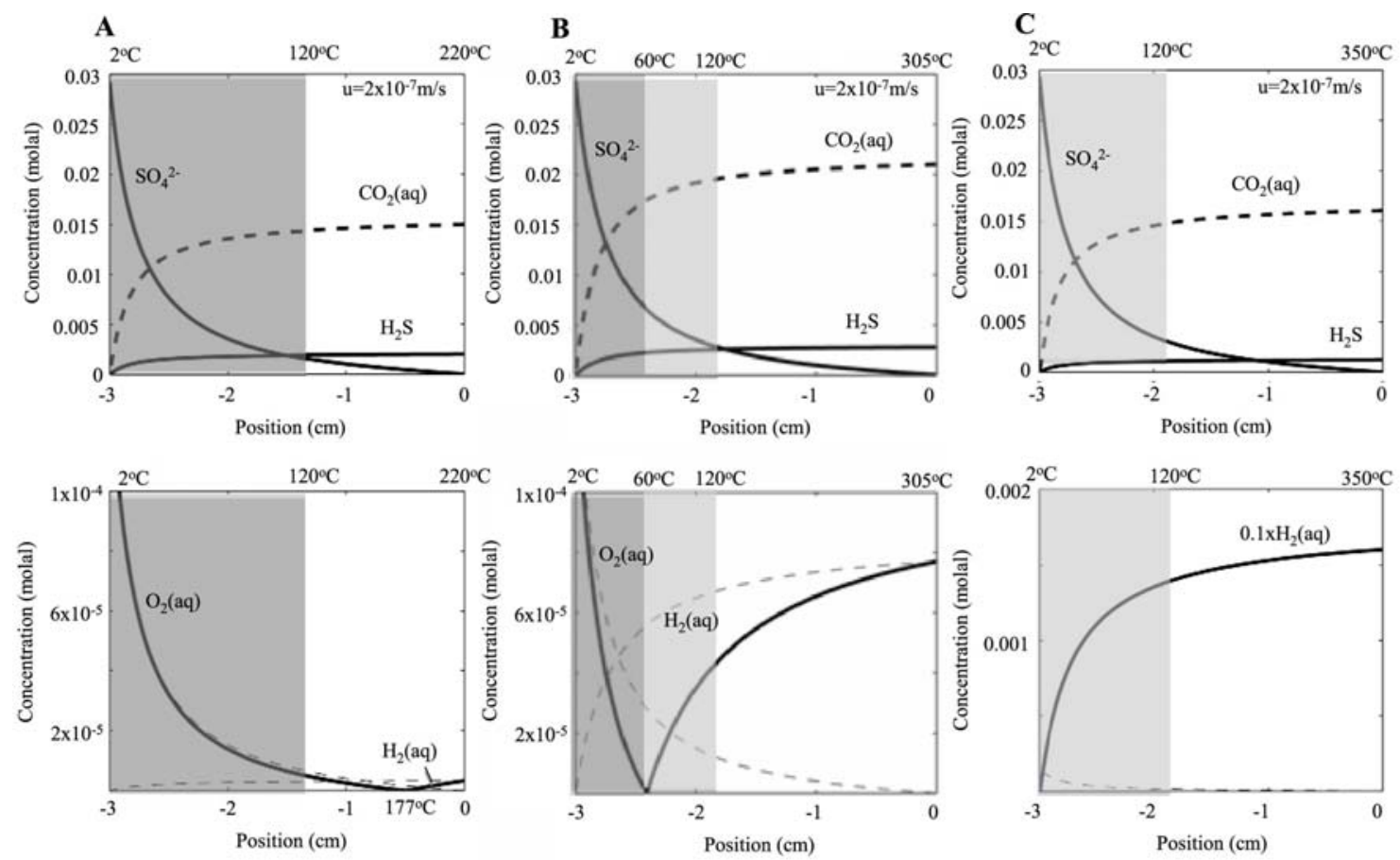

Figure 2.7. Concentrations across a uniformly porous $(\phi=0.5) 3$-cm thick chimney wall resulting from transport between seawater (at position $=-3 \mathrm{~cm}$ ) and $\mathbf{A}, 220^{\circ} \mathrm{C}$ Sintra vent fluid (Lucky Strike), B, $305^{\circ} \mathrm{C}$ Marker 6 vent fluid (Lucky Strike), C, $350^{\circ} \mathrm{C}$ Flores5 vent fluid (Rainbow) at position $=0 \mathrm{~cm}$ by diffusion and advection of vent fluid outward at a rate of $2 \times 10^{-}$ ${ }^{7} \mathrm{~m} \mathrm{~s}^{-1}(\mathrm{u})$. Shading indicates where conditions at temperatures $\leq 120{ }^{\circ} \mathrm{C}$ are relatively oxidizing (dark grey) or highly reduced (light grey). Calculations were done as described by Tivey (2004). End-member concentrations (For Flores5, $\mathrm{H}_{2}=16 \mathrm{mM}, \mathrm{H}_{2} \mathrm{~S}=1.2 \mathrm{mM} ; \mathrm{CO}_{2}=$ $16 \mathrm{mM}$; for Sintra $\mathrm{H}_{2}=3.3 \mathrm{uM}, \mathrm{H}_{2} \mathrm{~S}=2 \mathrm{mM} ; \mathrm{CO}_{2}=15.1 \mathrm{mM}$; for Marker $6 \mathrm{H}_{2}=77 \mathrm{uM}, \mathrm{H}_{2} \mathrm{~S}$ $=2.8 \mathrm{mM} ; \mathrm{CO}_{2}=20.7 \mathrm{mM}$; from Charlou et al. $(2000 ; 2002)$. Note the absence of relatively oxidizing conditions within the Rainbow (Flores5) chimney versus the prediction of oxidizing conditions up to temperatures of $177^{\circ} \mathrm{C}$ and $60^{\circ} \mathrm{C}$ for Lucky Strike chimneys, depending on the concentration of aqueous $\mathrm{H}_{2}$ in the end-member vent fluid and the advection rate. (Dashed lines in lower half of figure are for $\mathrm{O}_{2}$ and $\mathrm{H}_{2}$ concentrations if oxidation of $\mathrm{H}_{2}$ is inhibited as suggested by Shock and Holland (2004)). 

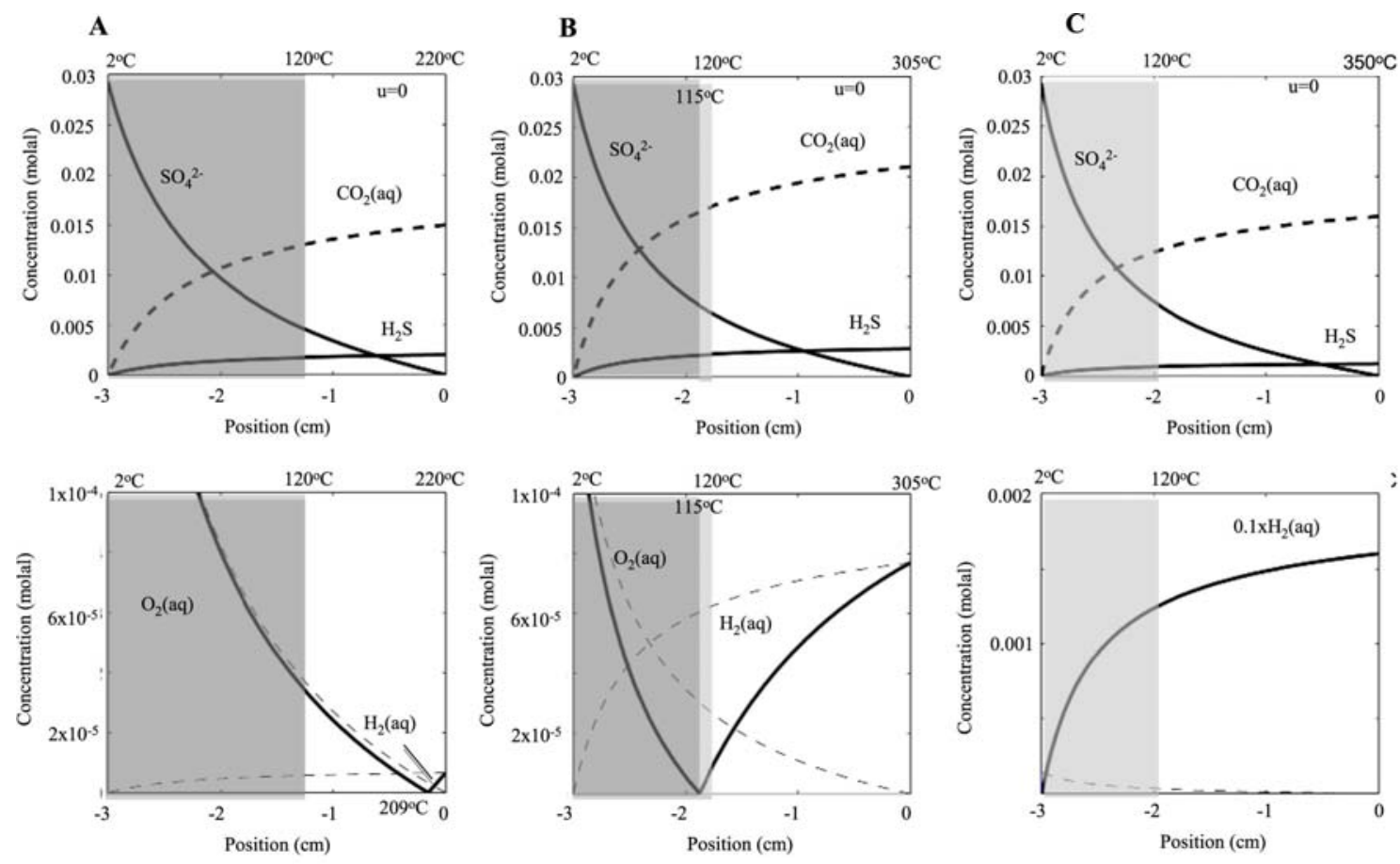

Figure 2.8. Concentrations across a uniformly porous $(\phi=0.5) 3$-cm thick chimney wall resulting from transport between seawater (at position $=-3 \mathrm{~cm}$ ) A, $220^{\circ} \mathrm{C}$ Sintra vent fluid (Lucky Strike), B, $305^{\circ} \mathrm{C}$ Marker 6 vent fluid (Lucky Strike), C, $350^{\circ} \mathrm{C}$ Flores5 vent fluid (Rainbow) at position $=0 \mathrm{~cm}$ by diffusion only. (see Figure 2.7 caption for more details of calculations). Note the lack of oxidizing zone for the Rainbow chimney even with no outward advection of vent fluid.

In contrast to at Lucky Strike, the very high concentrations of aqueous $\mathrm{H}_{2}$ in Rainbow fluids result in reducing pore fluids within all portions of Rainbow chimneys, even exterior layers surrounded by oxic seawater (Figure 2.7C). Methanogenesis and sulfate-reduction are energetically favorable reactions that would produce metabolic energies comparable to those calculated for reducing zones in other chimneys (Tivey, 2004) and reduced mixing zones (McCollom and Shock, 1997; Takai and Nakamura, 2010). On the other hand, sulfide-oxidation and methanotrophy would not be expected 
to be favorable reactions anywhere within Rainbow chimneys, though could occur if equilibrium between $\mathrm{H}_{2}$ and $\mathrm{O}_{2}$ was kinetically inhibited, as proposed by Shock and Holland (2004) and demonstrated as possible, particularly at lower temperatures, by Foustoukos et al. (2011). The dashed lines in the bottom panels of Figures 2.7 and 2.8 show predicted amounts of $\mathrm{H}_{2}$ and $\mathrm{O}_{2}$ if equilibration between the two species is completely inhibited (i.e., maximum amounts of $\mathrm{O}_{2}$ or $\mathrm{H}_{2}$ that might be present in zones that would be predicted to be relatively oxidizing or reducing assuming equilibrium between the two species). For example at the Flores5 vent at Rainbow, a very small amount of metabolic energy (an order of magnitude less than in Lucky Strike outer layers), would be available in outermost layers (e.g., at $7^{\circ} \mathrm{C}$ ) from methanotrophy if there was complete inhibition of equilibrium between $\mathrm{H}_{2}$ and $\mathrm{O}_{2}$, and the amount of metabolic energy from sulfate-reduction would be comparable to that in Lucky Strike exterior layers. At the low temperature of $7^{\circ} \mathrm{C}$, inhibition might be expected (Foustoukos et al., 2011). In Lucky Strike chimneys, if equilibration is completely inhibited, methanogenesis would be thermodynamically favorable in chimneys formed from Marker 6 fluids at temperatures less than $60^{\circ} \mathrm{C}$, and from Sintra fluids at temperatures less than $177^{\circ} \mathrm{C}$, but amounts of metabolic energy would be considerably less than from sulfide-oxidation (two-thirds less for Sintra fluids, half for Marker 6 fluids). In addition, at these higher temperatures, the rate of equilibration between $\mathrm{H}_{2}$ and $\mathrm{O}_{2}$ would be higher than at lower temperatures (Foustoukos et al., 2011).

The differences in predicted redox conditions in the exteriors of the deposits help to explain the abundance of Aeropyrum at Lucky Strike and Staphylothermus and 
methanogens at Rainbow. Additionally, the unusually low concentrations of $\mathrm{H}_{2}$ in exteriors of Lucky Strike deposits (Figure 2.7A - C, Figure 2.8A - C) most likely cannot support methanogenesis, particularly given competition with other thermophilic hydrogen-oxidizers such as members of the Archaeoglobaceae and Desulfurococcaceae. Certain members of these families would also have an advantage over methanogens by being able to use alternative electron-donors when $\mathrm{H}_{2}$ was unavailable (Boone et al., 2001). Interestingly, the archaeal diversity of Rb-2 shows some similarity with those of Lucky Strike deposits (Figure 2.5A). This sample is from a highly-porous few-millimeter-thick distinct outer layer of a chimney (Figure 2.9). The $\mathrm{Rb}-3$ sample was taken from the less porous, harder interior layer adjacent to $\mathrm{Rb}-2$. The fluid sampled from this vent had slightly lower measured $\mathrm{H}_{2}$ as compared to other Rainbow fluids ( $\sim 12 \mathrm{mmol} / \mathrm{kg}$ versus $\sim 16 \mathrm{mmol} / \mathrm{kg}$, Table 2.5$)$. More efficient mixing of seawater may have occurred within the very porous (and likely more permeable) outer layer (Rb-2), which would result in even lower $\mathrm{H}_{2}$, while the interior layer $(\mathrm{Rb}-3)$ would remain reducing and support methanogens. These findings suggest that in addition to local hydrothermal fluid chemistry influencing microbial diversity, withinfield variability in archaeal diversity can be influenced by fluid mixing styles and deposit porosity and permeability. 


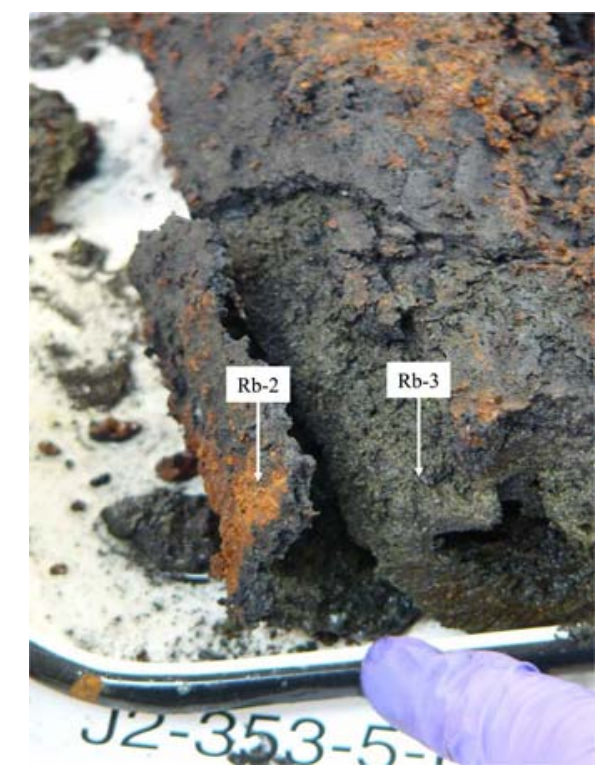

Figure 2.9. Photograph of the hydrothermal vent chimney used for samples Rb-2 and Rb-3. Note how the porous, outer layer (Rb-2) cleanly peels away from the rest of the chimney sample.

Table 2.5. End-member fluid chemistry of samples used for microbial community characterizations.

\begin{tabular}{lcccccc}
\hline $\begin{array}{l}\text { Sample } \\
\text { name }\end{array}$ & $\begin{array}{c}\text { Max. fluid } \\
\text { temp }\left({ }^{\circ} \mathrm{C}\right)^{\#}\end{array}$ & $\begin{array}{c}\mathrm{pH} \\
\left(25^{\circ} \mathrm{C}\right)\end{array}$ & $\begin{array}{c}\mathrm{H}_{2} \\
(\mathrm{mmol} / \mathrm{L})\end{array}$ & $\begin{array}{c}\Sigma \mathrm{H}_{2} \mathrm{~S} \\
(\mathrm{mmol} / \mathrm{L})\end{array}$ & $\begin{array}{c}\mathrm{CH}_{4} \\
(\mathrm{mmol} / \mathrm{L})\end{array}$ & $\begin{array}{c}\Sigma \mathrm{CO}_{2} \\
(\mathrm{mmol} / \mathrm{Kg})\end{array}$ \\
\hline $\mathrm{Rb}-1$ & 370 & 3.3 & 16 & 2.4 & 2.0 & 23 \\
$\mathrm{Rb}-2$ & 350 & 3.4 & 12 & 3.3 & 1.9 & 21 \\
$\mathrm{Rb}-3$ & 350 & 3.4 & 12.3 & 3.3 & 1.9 & 21 \\
$\mathrm{Rb}-4$ & - & - & - & - & - & - \\
$\mathrm{Rb}-5$ & - & - & - & - & - & - \\
$\mathrm{Rb}-6$ & - & - & - & - & - & - \\
$\mathrm{LS}-7$ & 324 & 3.9 & 0.071 & 3.1 & 1.1 & 35 \\
$\mathrm{LS}-8$ & - & - & - & - & - & - \\
$\mathrm{LS}-9$ & 236 & 3.7 & 0.025 & 2.4 & 0.84 & 101 \\
$\mathrm{LS}-10$ & 217 & - & - & - & - & - \\
$\mathrm{LS}-11$ & 184 & - & - & - & - & - \\
LS-12 & - & - & - & - & - & - \\
\hline
\end{tabular}

\footnotetext{
${ }^{\#}$ maximum fluid temperatures recorded after sample collection when possible.
} 


\section{Bacteria}

Of the 91,607 bacterial V4 amplicons sequenced from the 12 hydrothermal vent samples, approximately 61\% (56,091) were classified as Epsilonproteobacteria (Figure 2.5C). Epsilonproteobacteria are known to play significant roles in carbon and sulfur cycling and have consistently been shown to be the most numerically abundant bacteria in these environments (Longnecker and Reysenbach, 2001; Nakagawa et al., 2005c; Campbell et al., 2006; Opatkiewicz et al., 2009; Huber et al., 2010). On a sample by sample basis, Epsilonproteobacteria were the most abundant sequences observed in three of the Rainbow and all of the Lucky Strike samples (Figure 2.5C). Within the Epsilonproteobacteria, the moderately thermophilic Caminibacter and Nautilia, and the mesophilic Nitratifractor and Sulfurovum were detected in all samples although abundances differed likely reflecting the different temperature regimes across individual deposits (Figure 2.10A). The diversity within the Sulfurovum, Caminibacter and Nitratifractor was surprisingly high with several OTUs identified by SIMPER as being found exclusively at one vent field (Table 2.6). This suggests that differences in the epsilonproteobacterial communities between Rainbow and Lucky Strike are at a finer scale (e.g., species or ecotype level) than what can be resolved with 16S rRNA gene sequences alone. These differences, however, may be significant as different OTUs within the same genus could be filling different ecological niches. For example, two hydrogen-oxidizing Caminibacter species previously isolated from Rainbow show differences in their oxygen tolerance as $C$. mediatlanticus is a strict anaerobe while $C$. profundus grows optimally with $0.5 \%$ oxygen (Miroshnichenko et al., 2004; 
Voordeckers et al., 2005). Therefore, although all OTUs classified as Caminibacter are treated equally, OTU level differences may be in response to similar geochemical properties that shape the archaeal communities. Yet, the isolated nature of these environments may also foster allopatric speciation within each vent field. Nonetheless, these results suggest that biogeographical provincialism occurs for free-living microbes as it does with vent invertebrates in deep-sea hydrothermal environments (Ramirez-

Llodra et al., 2007).

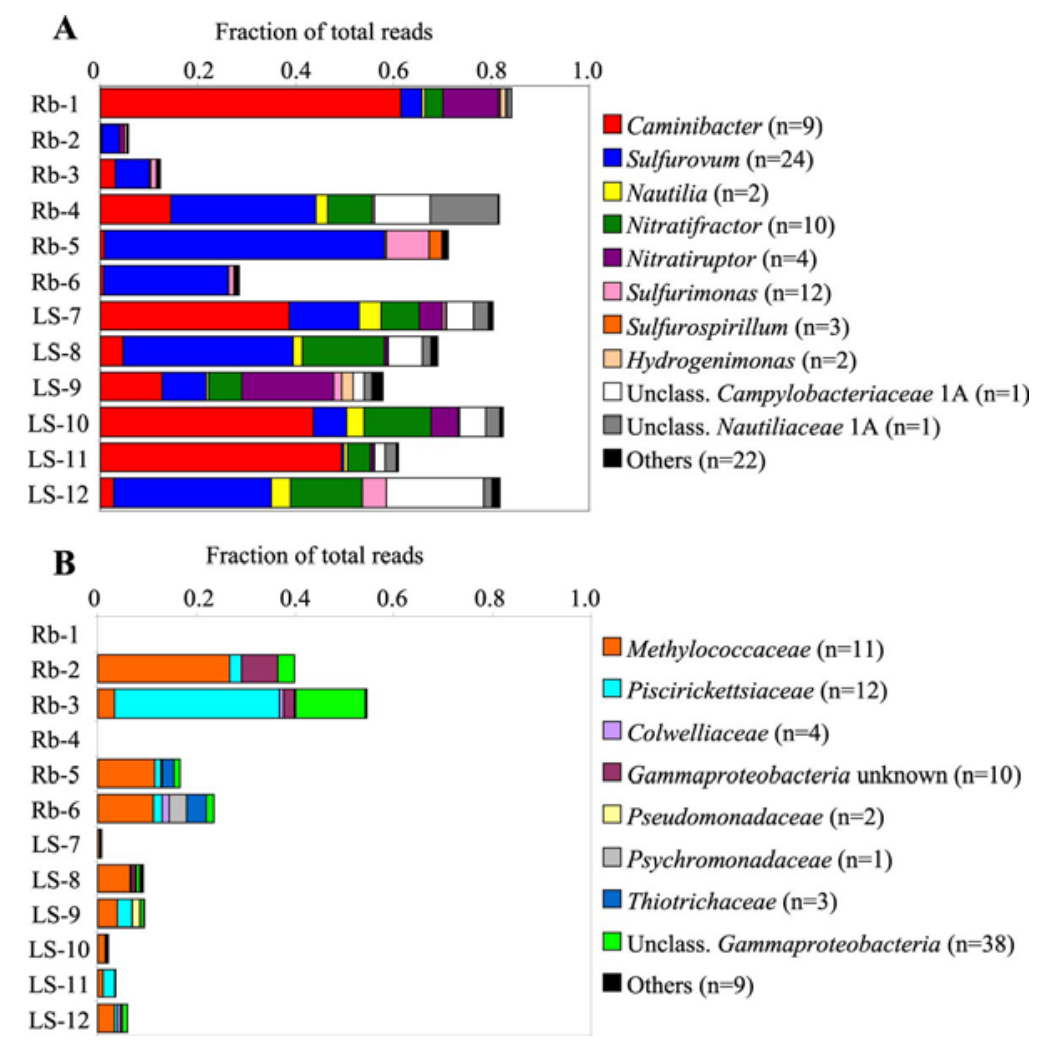

Figure 2.10. Comparison of taxonomic variation in the bacterial communities of Rainbow and Lucky Strike hydrothermal vent deposits. A, Relative abundances of epsilonproteobacterial genera observed in each vent deposit. B, Relative abundances of gammaproteobacterial families observed in each vent deposit. Numbers in parentheses following taxonomic classifications indicate the number of OTUs classified to that particular group. $\mathrm{Rb}=$ Rainbow, $\mathrm{LS}=\mathrm{Lucky}$ Strike. 
Table 2.6. SIMPER analysis was used to identify bacterial genera responsible for the dissimilarity observed in the communities of Rainbow and Lucky Strike vent deposits.

\begin{tabular}{|c|c|c|c|c|c|}
\hline Genus classification & ID \# & $\begin{array}{c}\text { Rainbow } \\
\text { Average } \\
\text { Abundance* }\end{array}$ & $\begin{array}{l}\text { Lucky Strike } \\
\text { Average } \\
\text { Abundance* }\end{array}$ & $\begin{array}{c}\text { Dissimilarity } \\
\text { contribution } \\
(\%)\end{array}$ & $\begin{array}{c}\text { Cumulative } \\
\text { dissimilarity } \\
(\%)\end{array}$ \\
\hline Caminibacter & 1293 & 1 & 0 & 2.06 & 2.06 \\
\hline Nitratifractor & 7 & 0 & 1 & 2.06 & 4.12 \\
\hline Thermodesulfatator & 929 & 1 & 0 & 2.06 & 6.17 \\
\hline Thermodesulfobacterium & 1907 & 1 & 0 & 2.06 & 8.23 \\
\hline Nautilia & 1094 & 1 & 0 & 2.06 & 10.29 \\
\hline Unclassified Bacteria & 21 & 0 & 1 & 2.06 & 12.35 \\
\hline Thermodesulfatator & 1263 & 1 & 0 & 2.06 & 14.4 \\
\hline Desulfonauticus & 863 & 0.83 & 0 & 1.72 & 16.12 \\
\hline Nautilia & 5 & 0.17 & 1 & 1.71 & 17.83 \\
\hline Hippea & 122 & 0.17 & 1 & 1.71 & 19.53 \\
\hline Sulfurovum & 30 & 0 & 0.83 & 1.68 & 21.21 \\
\hline Caldithrix & 62 & 0 & 0.83 & 1.68 & 22.89 \\
\hline Unclassified Bacteria & 20 & 0 & 0.83 & 1.68 & 24.57 \\
\hline Desulfobulbus & 1672 & 0.83 & 0.17 & 1.5 & 26.07 \\
\hline Caldisericum & 6 & 0.17 & 0.83 & 1.48 & 27.54 \\
\hline Caminibacter & 10 & 0.17 & 0.83 & 1.47 & 29.01 \\
\hline Colwellia & 914 & 0.67 & 0 & 1.33 & 30.35 \\
\hline OD1 & 152 & 0.33 & 1 & 1.33 & 31.68 \\
\hline Sulfurovum & 242 & 0 & 0.67 & 1.33 & 33.01 \\
\hline Sulfurovum & 14 & 0.33 & 0.83 & 1.27 & 34.28 \\
\hline
\end{tabular}

*Abundances reflect the presence or absence of particular OTUs in each sample from the two vent fields with 1 indicating the presence of that OTU in all samples from that vent field and 0 representing a complete absence.

Of the samples not dominated by Epsilonproteobacteria, two were dominated by Gammaproteobacteria (Rb-2, -3) and one by unclassified sequences related to the Thermotogae (Rb-6) (Figure 2.5C). Taxa of the Gammaproteobacteria observed in most samples include the mesophilic sulfide-oxidizing Thiomicrospira and several genera within the methylotrophic Methylococcaceae (Figure 2.10B). Although two of the Rainbow deposits $(\mathrm{Rb}-1,-4)$ had very few sequences classified as Gammaproteobacteria, there was an overall greater diversity of Methylococcaceae at Rainbow, perhaps reflecting the higher concentrations of abiotic (and biotic) methane generated in ultramafic environments and identifying another metabolism preferentially 
enriched for in ultramafic environments. Because the sequences in Rb-6 are only distantly related to the Thermotogales, they are likely a novel deep-sea group whose primary metabolism in unknown.

Differences in the less abundant bacterial thermophilic members corroborated many of the archaeal community observations (Figure 2.5D). For example, the hydrogen-oxidizing sulfate-reducing Thermodesulfatator and Thermodesulfobacterium were detected in all Rainbow samples but were only detected in one of the Lucky Strike deposits. Within the Deltaproteobacteria, the genus Desulfonauticus, a moderately thermophilic hydrogen-oxidizing sulfate-reducer, was observed in five of six Rainbow samples and not in any of the Lucky Strike deposits further suggesting enriched diversity of thermophilic hydrogen-oxidizers at Rainbow. SIMPER also identified these OTUs as being some of the most significant drivers of bacterial community differences (Table 2.6).

\section{Conclusions}

As some studies have pointed to the possible role of subsurface geochemical processes such as phase-separation as drivers for microbial diversity at vents, the small sample sizes have compromised the reported conclusions (Nakagawa et al., 2005d; Nunoura and Takai, 2009). Our data from the microbial communities colonizing hydrothermal deposits show at multiple taxonomic levels that there is a direct coupling of geological, geochemical and microbiological processes at deep-sea hydrothermal vents. At the ultramafically-hosted site, Rainbow, the high concentrations of aqueous 
$\mathrm{H}_{2}$ in the vent fluids resulting from serpentinization reactions allows for methanogens to flourish. Conversely, Lucky Strike vent fluids have very low aqueous $\mathrm{H}_{2}$ concentrations and are oxidizing relative to most mid-ocean ridge vent fluids (Charlou et al., 2000; Charlou et al., 2002). In addition, some of the vent fluids at Lucky Strike exhibit evidence of conductive cooling in the subsurface (attributed to the presence of impermeable cap rocks that trap fluids, Rouxel et al., 2004b) and for seawater entrainment into the subsurface (Humphris et al., 2002), which would result in venting of even more oxidizing fluids at the seafloor. Therefore, in the actively venting deposits at Lucky Strike, the conditions are not suitable for the growth of thermophilic methanogens, but are for growth of microaerophilic hyperthermophiles.

Here we have only considered the pore fluids as the source of reduced or oxidized species providing energy for the microbial communities. The mineral surfaces may also play a role, but that was not investigated in this study. What is known both from past studies of deposits samples at Lucky Strike and Rainbow vent fields, and from analysis of samples collected in this study, is that the mineral assemblages present in Rainbow versus Lucky Strike vent deposits indicate significantly more reducing conditions in Rainbow deposits, with pyrrhotite $\left(\mathrm{Fe}_{1-x} \mathrm{~S}\right)$ and cubanite $\left(\mathrm{CuFe}_{2} \mathrm{~S}_{3}\right)$ more prevalent at Rainbow and marcasite and pyrite $\left(\mathrm{FeS}_{2}\right)$ and chalcopyrite $\left(\mathrm{CuFeS}_{2}\right)$ more prevalent at Lucky Strike (Langmuir et al., 1997; Rouxel et al., 2004a, b). The redox state of these minerals (more versus less reducing) may further affect microenvironments within the chimneys, further influencing microbial communities. 
Lucky Strike and Rainbow vent fields represent the opposite ends of the geochemical spectrum along the Mid-Atlantic Ridge hydrothermal vent fields, particularly with respect to $\mathrm{H}_{2}$ concentrations. Extending this sampling and deep sequencing approach to other vent fields in different geologic settings and including more fine scale mineralogical and textural analyses, is needed to identify the full suite of geologic and geochemical properties that influence microbial community structure and will provide boundaries for future modeling efforts.

\section{Materials and Methods}

Sample collection and DNA extraction.

Vent deposit samples were collected during July/August 2008 from the Rainbow and Lucky Strike vent fields using the robotic manipulators of the remotely operated vehicle (ROV) Jason II. Upon collection, samples were placed in sealed, custom made bioboxes to minimize contamination from surrounding seawater. After surfacing, samples were removed from bioboxes and sampled using published methods (Götz et al., 2002; Reysenbach et al., 2006). For samples Rainbow-1, -2, -4, -5 and Lucky Strike-7, $-8,-9,-12$ approximately $1-4 \mathrm{~mm}$ of the outer biofilm-encrusted surface was removed and homogenized using sterile mortar and pestles. For samples Lucky Strike10 and -11 , outer biofilm crusts were homogenized with inner sections as they could not be easily separated from the rock. For samples Rainbow-3 and -6, interior sections of the deposits were homogenized after removal of the outer crust. Homogenized samples 
were stored in cryovials at $-80^{\circ} \mathrm{C}$ for subsequent DNA extraction. Nucleic acids for pyrosequencing, clone libraries and qPCR were extracted from homogenized samples $(\approx 1.6-3.2$ grams) using the Ultra Clean Soil DNA Isolation Kit (MoBio Laboratories) according to the modified protocol of Reysenbach et al. (2006).

\section{Hydrothermal fluid chemistry}

Hydrothermal fluids were collected using isobaric gas-tight fluid samplers (Seewald et al., 2002) deployed from the ROV Jason II and processed immediately following recovery on the ship. Vent fluid temperature was monitored continuously during fluid sampling using a thermocouple attached to the end of the sampler inlet snorkel. The reported temperatures (Tables 2.1 and 2.5) represent maximum values recorded for each vent. Shipboard analysis of dissolved $\mathrm{H}_{2}$ and $\mathrm{CH}_{4}$ concentrations was accomplished using gas chromatography following headspace extraction. Samples aliquots were archived in gas-tight serum vials for shore-based determination of total dissolved $\mathrm{CO}_{2}\left(\Sigma \mathrm{CO}_{2}\right)$ by gas chromatography following acidification and headspace extraction. Total dissolved $\mathrm{H}_{2} \mathrm{~S}\left(\Sigma \mathrm{H}_{2} \mathrm{~S}\right)$ and $\mathrm{pH}\left(25^{\circ} \mathrm{C}\right)$ were determined at sea by

electrochemical titration using a sulfide specific electrode and a Thermo-Ross ${ }^{\mathrm{TM}}$ glass electrode, respectively. 
454 Pyrosequencing

For amplifying the hypervariable V4 region of the SSU rRNA gene of Archaea, we used as forward primer oligonucleotides that contained a modified U519F primer sequence (Suzuki and Giovannoni, 1996) fused to 6-nucleotide key tags (Cole et al., 2009) and to the 454 FLX sequencing primer A

(5'GCCTCCCTCGCGCCATCAGxxxxxxCAGYMGCCRCGGKAAHACC, where the $\mathrm{x}$ region represents the key tag and the SSU rRNA primer is bold). To allow multiplex sequencing, ten such primers were synthesized (Integrated DNA Technologies; HPLC purified), each with a different key tag. The reverse oligonucleotide primer represented a fusion of the 454 FLX sequencing primer B and a modified Arch806R primer (Takai and Horikoshi, 2000a)

(5'GCCTTGCCAGCCCGCTCAGGGACTACNSGGGTMTCTAAT, where the 16S rRNA region is bold). PCR reactions (50- $\mu$ l volume) contained $300 \mathrm{nM}$ of each of forward and reverse primers, 20-50 ng template DNA and were performed using Platinum Taq High Fidelity polymerase (Invitrogen, Carlsbad, CA) using the thermal profile $95^{\circ} \mathrm{C}$ for 2 min followed by 27 cycles of denaturation at $95^{\circ} \mathrm{C}$ for $15 \mathrm{sec}$, primer annealing at $53^{\circ} \mathrm{C}$ and extension at $68^{\circ} \mathrm{C}$ for $45 \mathrm{sec}$, with final extension of $68^{\circ} \mathrm{C}$ for 3 min. For a few samples the amount of template DNA was limiting and additional 3-5 PCR cycles were necessary in order to obtain a sufficient product. Negative control reactions without template were always performed.

The bacterial hypervariable V4 region of the SSU rRNA gene was amplified using a similar approach, using as forward primer key-tagged oligonucleotides 
5'GCCTCCCTCGCGCCATCAGxxxxxxAYTGGGYDTAAAGNG3') and a mix of reverse primers (5'GCCTTGCCAGCCCGCTCAG:TACCRGGGTHTCTAATCC, :TACCAGAGTATCTAATTC, :CTACDSRGGTMTCTAATC and :TACNVGGGTATCTAATCC3' in a 6:1:2:12 ratio, respectively), designed to cover most of the Bacteria domain (Cole et al., 2009). The amplification protocol was the same as for Archaea except that the annealing temperature was $55^{\circ} \mathrm{C}$.

The amplicon products were purified using AMPure paramagnetic beads (Agencourt Bioscience Corporation, Beverly, MA) followed by analysis of their concentration and size using DNA 1000 chips on an Agilent 2100 Bioanalyzer (Agilent Technologies, Inc., Waldbronn, Germany). Amplicon libraries were prepared for unidirectional sequencing using the emPCR Kit II (Roche) followed by sequencing on a 454 Life Sciences Genome Sequencer FLX (Roche Diagnostics, Indianapolis, IN). Based on the use of identifying key tags, twenty individual samples were pooled and sequenced on each of the two sides of the picotiter plate.

Raw sequence data was initially processed through the RDP's (Ribosomal Database Project) Pyrosequencing Pipeline (http://pyro.cme.msu.edu/) (Cole et al., 2009). Sequences were excluded from analysis if they had a mean quality score $<20$, were $<200$ or $>275 \mathrm{bp}$ in length (Archaea) $(>250$ for Bacteria), contained ambiguous nucleotides (N's), or had any mismatches in the forward and reverse primers. The sequences were assigned to individual samples by their key tag and the 16S rRNA primers were removed prior to analysis. Trimmed sequences were then subjected to an initial pre-classification step using the RDP-classifier (Wang et al., 2007) in which 
unclassified sequences (not Archaea or Bacteria) or sequences classified to the incorrect domain (e.g., Bacteria in the archaeal data set) were removed. The resulting datasets contained 207-208 nt of the bacterial and 247-249 nt of the archaeal V4 region, respectively.

\section{Sequence analysis}

Trimmed sequenced files were aligned with the secondary-structure aware Infernal aligner (Nawrocki et al., 2009) and clustered using the complete-linkage clustering method (furthest-neighbor) available through the RDP's pyrosequencing pipeline (Cole et al., 2009). Sequences were also aligned and clustered using the SLP/PW-AL pipeline (Huse et al., 2010). Individual cluster files from both methods were used to generate rarefaction curves (Colwell and Coddington, 1994) and Chao1 richness estimator (Chao and Bunge, 2002) at different OTU similarity levels (97\% and 95\%). Custom perl scripts were used on combined cluster files to develop abundance matrices for both archaeal and bacterial clusters. A second script was used to select representative sequences of each cluster and these sequences were run through the RDP classifier (Wang et al., 2007) set at a 50\% bootstrap cutoff as recommended by Claesson et al. (2009). Classifications were downloaded and a third script was used to link the classifications back to the original cluster files. The taxonomic results presented here were generated from the RDP OTUs at $95 \%$ similarity. We chose to use this method for analysis because the V4 region performs best with the infernal aligner used by RDP (Nawrocki et al., 2009) and less stringent clustering values have been 
shown to minimize overestimates of diversity (White et al., 2010). Selected sequences representing clusters that could not be classified by the RDP classifier were further examined by BLAST searches against the GenBank's non-redundant database (Benson et al., 2009), aligning sequences in ARB (Ludwig et al., 2004) and inserting them into the Silva-96 reference tree (Pruesse et al., 2007) using the quick add function. When possible, clusters were then given a taxonomic classification based on published nomenclature otherwise a generic identifier (e.g., Unclassified Archaea A) was used to track OTUs between samples.

For OTU-based beta-diversity assessments, abundance matrices were imported into Primer v6. Bray-Curtis similarities were calculated on matrices that had been normalized to total and transformed via square root while Sørensen similarities were calculated directly from abundance matrices. Distance matrices were also generated for both archaeal and bacterial communities using the phylogeny-based metric UniFrac (Lozupone et al., 2006; Hamady et al., 2010). First, for each of the Bacteria and Archaea global datasets we grouped the sequences in OTU clusters using either 97\% or 95\% sequence similarity levels, using the RDP Pyrosequencing Pipeline. We then extracted one sequence from each OTU cluster to construct hydrothermal vent reference datasets for either Bacteria ( 811 sequences at $97 \%$ and 648 sequences at $95 \%$ sequence similarity, respectively) or Archaea (310 sequences at 97\% and 229 sequences at 95\% sequence similarity, respectively). For tree rooting, we added the SSU rRNA sequences of either Nanoarchaeum equitans (Genbank AJ318041) (Archaea dataset) or Hydrogenobaculum sp. (GenBank AY861719) (Bacteria dataset), trimmed to 
correspond to the sequenced V4 region followed by aligning using the RDP aligner. Maximum likelihood rooted phylogenetic trees were then constructed using RAxML7.0.4 (Stamatakis, 2006) using the GTRGAMMA parameter and 100 independent searches for the best tree. After assigning of each individual sequence from the global datasets to their closest representatives in the reference datasets using local BLAST, the UniFrac sample ID mapping file was generated using a python script, according to the Fast UniFrac data analysis flow. The online Fast UniFrac pipeline was used for the subsequent analysis, including generation of the UniFrac distance matrix. The same results were obtained using either the $97 \%$ or the $95 \%$ sequence similarity datasets. The presented figures are based on the $97 \%$ sequence similarity trees and matrices. In parallel, we also used the Greengenes core sequence dataset and tree that are available as part of the online FastUnifrac for mapping and preliminary analysis, with similar results (not shown). Similarity and distance matrices were analyzed using principal coordinates analysis (PCoA) (not shown), non-metric multi-dimensional scaling (MDS), and tested for significance using ANOSIM. We chose to use MDS instead of other ordination methods like PCoA because it is more flexible in converting (dis)similarity to distances and preserving these relationships in low-dimensional space (Clarke and Gorley, 2006). Similarities/distances were averaged within and between vent sites and tested for significance using a one-tailed T-test. All distance matrix analyses except PCoA was performed with PRIMER v6 (Clarke and Gorley, 2006). 


\section{SIMPER analysis}

To help identify which organisms were responsible for the differences observed in community composition, we used SIMPER ("similarity percentages") in PRIMER v6 after classifying each OTU to the genus level (when possible) (Clarke and Gorley, 2006). The top 50 archaeal OTUs across samples were classified, imported into PRIMER v6, normalized by abundance in each sample, square-root transformed and then analyzed with SIMPER. The top 100 bacterial OTUs were treated similarly with the exception that data were transformed to a presence/absence matrix to account for low abundant taxa.

\section{Quantitative PCR}

Quantitative PCR was performed according to manufacturer's instructions using the Quantitect SYBR green PCR kit (Qiagen, Inc., Valencia, CA) and $0.8 \mu \mathrm{M}$ final primer concentration, with melting curves performed at the end of each reaction to ensure product specificity. For total archaeal numbers, the protocol outlined by Reysenbach et al. (2006) was followed. For quantification of methanogens and sulfate reducers , qPCR with primers specific for the methyl coenzyme M reductase (mcrA) and the dissimilatory sulfite reductase $(d s r B)$ genes was performed according to published methods (Wilson et al., 2010). Gene copy numbers presented here were normalized by the amount of material in grams extracted. 


\section{Nucleotide sequence accession numbers}

Nucleotide sequences generated in this study have been deposited to the NCBI Sequence Read Archive (SRP005280) (454 pyrosequencing) and in GenBank under accession numbers HQ893885-HQ894378 (clone libraries). Trimmed 454 sequences are also available at http://alrlab.research.pdx.edu/projects/MAR2008.

\section{Contributions}

For this project, I collected and processed samples, extracted genomic DNA used for pyrosequencing, qPCR and clone libraries, constructed, analyzed and interpreted clone libraries with a high school student in the laboratory (Josh Steinberg), analyzed and interpreted qPCR data, analyzed and interpreted pyrosequencing data, and wrote the manuscript for publication. In doing so, I also developed a pipeline for analysis of pyrosequencing data with Jennifer Meneghin in the Reysenbach laboratory as these types of data were new to us. Geochemical modeling was performed by Margaret K. Tivey. Hydrothermal fluid composition was determined by Jeff Seewald. qPCR assays were performed by Julie Kirshtein. Pyrosequencing was performed by Mircea Podar, James Campbell and Zamin Yang. 


\title{
Chapter 3: Microbial Community Structure of Six Hydrothermal Vent Fields \\ From the Lau Back-Arc Basin
}

\begin{abstract}
In this study, we characterized the archaeal and bacterial communities of over 30 hydrothermal deposits from six vent fields located along the Eastern Lau Spreading Center (ELSC) in the Lau Basin. Using bar-coded pyrosequencing of the variable region 4 (V4) of the $16 \mathrm{~S}$ rRNA gene, we addressed two fundamental questions: 1) are the microbial communities in back-arc basins different than those from mid-ocean ridges, and 2) are the microbial communities in the ELSC different from one another? Results show that at higher taxonomic levels, the bacterial and archaeal communities of deposits from the ELSC are similar to other active vent deposits with a rich diversity of Epsilonproteobacteria and thermophilic Archaea. However, the bacterial and archaeal communities from the southernmost vent field, Mariner, were very different from the other vent fields along the ELSC. At Mariner, the bacterial genus Nautilia and the archaeal family Thermococcaceae were prevalent in most deposits, while Lebetimonas and Thermofilaceae were more abundant at the other vent fields. These differences appear to be driven by the higher concentrations of magmatic volatiles in the Mariner fluids and show that differences in geologic processes in back-arc basins can influence microbial diversity at the vent field scale.
\end{abstract}




\section{Introduction}

Marine hydrothermal vent deposits form as acidic, metal-rich, reduced hydrothermal fluids meet cold, alkaline and oxygenated seawater (Tivey, 2007). These porous deposits are characterized by steep physicochemical gradients that provide a range of microhabitats for colonizing microbes. Numerous Archaea and Bacteria that grow over a wide range of physical and chemical conditions have been isolated and characterized from vent deposits (e.g., Takai and Horikoshi, 2000b; Takai et al., 2000; Götz et al., 2002; Takai et al., 2002; Inagaki et al., 2003; Takai et al., 2003; Inagaki et al., 2004; Takai et al., 2004a; Nakagawa et al., 2005a; Nakagawa et al., 2005b; Takai et al., 2005; Reysenbach et al., 2006; Imachi et al., 2008; Takai et al., 2008). Several cultivation-independent studies employing 16S rRNA gene cloning have also been conducted in order to describe the archaeal and bacterial communities associated with actively venting structures (e.g., Takai and Horikoshi, 1999; Reysenbach et al., 2000; Corre et al., 2001; Takai et al., 2001; Nercessian et al., 2003; Schrenk et al., 2003; Nakagawa et al., 2005d; Page et al., 2008; Takai et al., 2008; Voordeckers et al., 2008; Nunoura and Takai, 2009; Zhou et al., 2009; Kato et al., 2010). Results of these studies have identified the Epsilonproteobacteria as being the dominant bacterial lineage associated with vent deposits (Campbell et al., 2006), while other bacterial groups like the Aquificales, Thermales, Thermotogales, Deltaproteobacteria and Thermodesulfurobacteriaceae are also commonly observed. Most Archaea associated with active vent deposits from cultivated lineages are thermophilic and belong to the Archaeoglobales, Thermococcales, Aciduliprofundales (DHVE2), Methanococcales and 
Desulfurococcales. However, numerous uncultivated archaeal lineages are also commonly observed.

While past studies have provided valuable information about the physiological potential and phylogenetic diversity of microbial communities associated with active vent deposits, we still have a limited understanding of factors that control the diversity and distribution patterns of microbes in these systems. As marine hydrothermal environments are found in diverse geological settings, it is important to characterize the microbial communities from a variety of these settings in order to determine such factors. Thus far, the majority of studies have been conducted along mid-ocean ridges (MOR) where oceanic plates diverge and basaltic lavas erupt forming the seafloor. Along convergent plate boundaries, oceanic crust is consumed as it is subducted beneath a continental plate, leading to the generation of andesitic island-arc volcanoes (Martinez et al., 2007). Adjacent to the island-arcs on the opposite side of the subducting slab, back-arc basins (BAB) form. Back-arc basins are extensional basins that are geologically diverse due to the presence of both convergent and divergent plate boundaries. The spreading centers generated here support hydrothermal environments that are in many ways similar to MORs. However, the composition of hydrothermal fluids in BABs are generally more variable than those from MORs due to differences in magma composition, heterogeneity of island-arc crust versus oceanic crust, and from inputs of the subducting slab (Gamo et al., 2006).

The Eastern Lau Spreading Center (ELSC) is a $397-\mathrm{km}$ segment that includes the Valu Fa Ridge (VFR) of the southernmost part of the back-arc spreading axis in the 
Lau Basin (Ferrini et al., 2008; Mottl et al., 2011). Located along this segment are several hydrothermal vent fields that exhibit systematic changes in spreading rate, magma source, subduction influence and host-rock composition from north to south (Figure 3.1). Generally, the northern vent fields are similar to typical MORs as they are more heavily influenced by the diverging plates. In contrast, the southern vent fields are influenced more by the converging plates as they are closer to the Tonga Trench. Hydrothermal fluids from four of the vent fields (Kilo Moana, Tow Cam, ABE and Tui Malila) are similar to fluids from other basalt-hosted MOR systems of similar temperature (Von Damm, 1995; German and Von Damm, 2004; Mottl et al., 2011). Fluids from these four vent fields exhibit a systematic decrease in temperature and an increase in $\mathrm{pH}$ from north to south (Mottl et al., 2011). This north-south trend is also generally true for concentrations of metabolically important compounds like aqueous hydrogen $\left(\mathrm{H}_{2}\right)$, hydrogen-sulfide $\left(\mathrm{H}_{2} \mathrm{~S}\right)$ and iron $(\mathrm{Fe})$ (Table 3.1). The north-south trend is reversed at the Mariner vent field (Figure 3.1). Fluids from Mariner are quite different than those elsewhere along the ELSC as they contain substantially higher concentrations of $\mathrm{CO}_{2}, \mathrm{Fe}$, and transition metals and are hotter and more acidic relative to the northern vents. Many of the differences in Mariner fluids are attributed to increased volatile inputs from an actively degassing magma chamber beneath this field (Mottl et al., 2011).

Because the geologic diversity along the ELSC provides an ideal setting for exploring factors that may influence patterns of microbial diversity associated with active vent deposits, we characterized the archaeal and bacterial communities of over 30 
deposits from six vent fields using bar-coded pyrosequencing. Results show that the unique geologic setting of the ELSC and BABs in general, can influence both archaeal and bacterial diversity at the vent field scale.

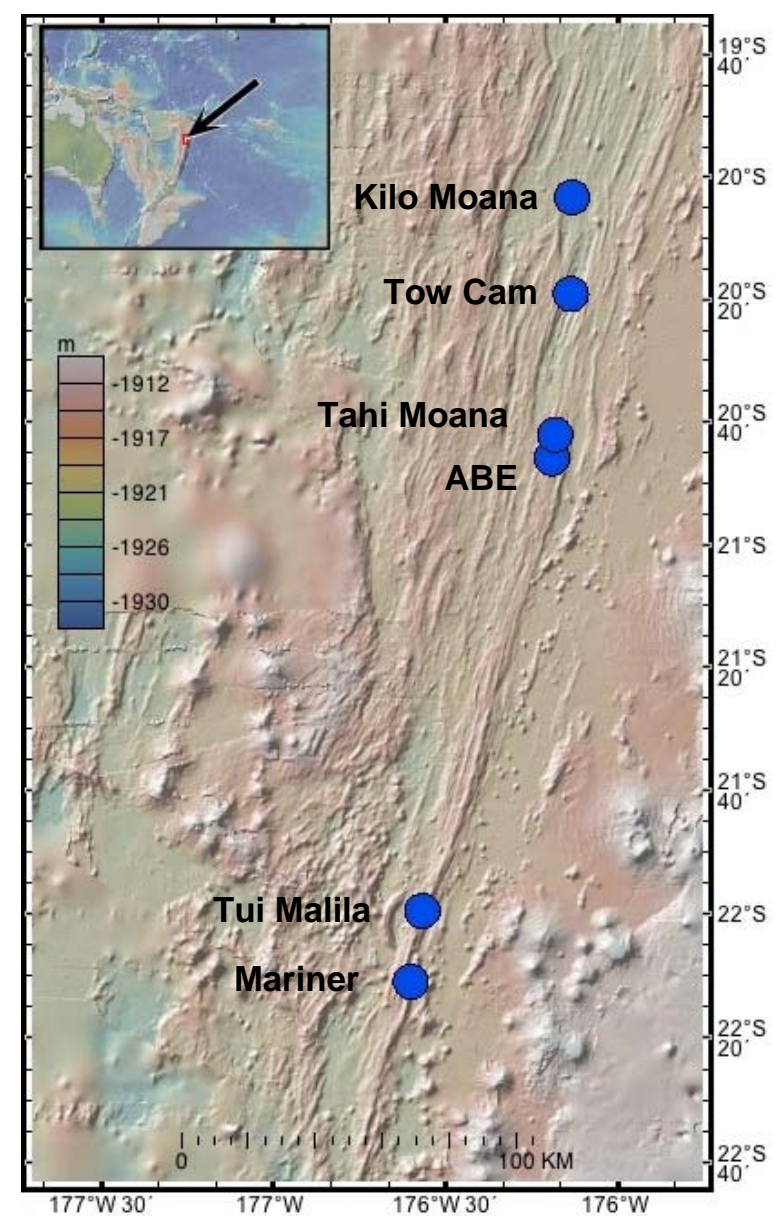

Figure 3.1. Location of hydrothermal vent fields along the Eastern Lau Spreading Center in the western Pacific Ocean. 
Table 3.1. Range of physico-chemical characteristics of end-member hydrothermal fluids from different vent fields along the Eastern Lau Spreading Center.

\begin{tabular}{|c|c|c|c|c|c|c|c|}
\hline Feature & Kilo Moana & Tow Cam & Tahi Moana & $\mathrm{ABE}$ & Tui Malila & Mariner & Seawater \\
\hline \multicolumn{8}{|l|}{ Temp $\left({ }^{\circ} \mathrm{C}\right)$} \\
\hline $2004 \S$ & & & & & & $179-365$ & \\
\hline $2005 ¥$ & $293-333$ & $287-328$ & & 269-309 & 229-312 & $240-363$ & \\
\hline $2009+$ & $290-304$ & 320 & $286-311$ & $297-317$ & $284-315$ & $338-359$ & 2 \\
\hline \multicolumn{8}{|l|}{$\mathrm{pH}$} \\
\hline 2004 & & & & & & $2.4-2.7$ & \\
\hline 2005 & $2.9-4.0$ & $3.7-4.1$ & & $4.3-4.6$ & $4.2-5.7$ & $2.5-2.7$ & \\
\hline 2009 & $3.9-4.1$ & 3.6 & $3.3-3.9$ & $3.9-4.0$ & $3.8-4.2$ & $2.2-2.4$ & 7.6 \\
\hline \multicolumn{8}{|l|}{$\mathrm{H}_{2}(\mu \mathrm{m} / \mathrm{kg})$} \\
\hline 2004 & & & & & & $44.9-95.5$ & \\
\hline 2005 & $220-498$ & $108-198$ & & $54-101$ & $35-135$ & $33-179$ & \\
\hline 2009 & & & & & & & $<0.001$ \\
\hline \multicolumn{8}{|c|}{$\mathrm{H}_{2} \mathrm{~S}(\mathrm{~mm} / \mathrm{kg})$} \\
\hline 2004 & & & & & & $6.9-9.0$ & \\
\hline 2005 & $5.4-6.4$ & $3.7-5.2$ & & $2.6-3.6$ & $1.2-2.5$ & $4.2-9.3$ & \\
\hline 2009 & $3.5-3.9$ & 4.8 & $3.1-4.1$ & & & $8.9-18$ & $<0.0001$ \\
\hline \multicolumn{8}{|c|}{$\mathrm{CH}_{4}(\mu \mathrm{m} / \mathrm{kg})$} \\
\hline 2004 & & & & & & $7.2-8.0$ & \\
\hline 2005 & $28-33$ & $44-48$ & & $42-57$ & $31-43$ & $5.1-7.7$ & \\
\hline 2009 & & & & & & & $<0.001$ \\
\hline \multicolumn{8}{|c|}{$\mathrm{CO}_{2}(\mathrm{~mm} / \mathrm{kg})$} \\
\hline 2004 & & & & & & $41.2-71.7$ & \\
\hline 2005 & $7.5-8.5$ & $10.5-11.5$ & & $5.1-6.9$ & $11.7-13.8$ & $32.3-71.4$ & \\
\hline 2009 & & & & & & & 2.3 \\
\hline \multicolumn{8}{|l|}{$\mathrm{Fe}(\mu \mathrm{m} / \mathrm{kg})$} \\
\hline 2004 & & & & & & $11.1-12.8^{*}$ & \\
\hline 2005 & $2,485-3,836$ & $267-368$ & & $158-374$ & $143-255$ & $10.5-13.0^{*}$ & \\
\hline 2009 & $534-592$ & 205 & $248-332$ & & & $11.6-13.1^{*}$ & 0.001 \\
\hline \multicolumn{8}{|l|}{$\mathrm{Mn}(\mu \mathrm{m} / \mathrm{kg})$} \\
\hline 2004 & & & & & & $4.9-6.0^{*}$ & \\
\hline 2005 & $512-733$ & $332-407$ & & $273-468$ & $332-441$ & $4.9-6.3 *$ & \\
\hline 2009 & $193-213$ & 326 & $302-468$ & & & $3.9-5.2 *$ & 0.005 \\
\hline
\end{tabular}




\section{Methods}

Sample collection

Hydrothermal vent deposits were obtained from six different vent fields along the ELSC in June/July 2009 during the TN236 cruise aboard the RV Thomas G. Thompson. Samples were collected using the robotic manipulators of the remotely operated vehicle (ROV) Jason II. Upon collection, samples were placed in sealed, custom made bioboxes to minimize contamination from surrounding seawater. Once shipboard, samples were subsampled as described previously (Götz et al., 2002; Reysenbach et al., 2006; Flores et al., 2011). Homogenized samples were stored in cryovials at $-80^{\circ} \mathrm{C}$ for subsequent DNA extraction. In total, 35 different deposits were used in this study (Figure 3.2, Table 3.2).

\section{Site descriptions}

The basalt-hosted Kilo Moana (KM) vent field $\left(176^{\circ} 08.03^{\prime} \mathrm{W}, 20^{\circ} 03.15^{\prime} \mathrm{S}\right)$ is at the northern end of the ELSC at depths between 2606-2640 meters where the spreading rate is fast and the crust is relatively thin (Figure 3.1) (Ferrini et al., 2008; Mottl et al., 2011). Hydrothermal activity here occurs in three areas that extends north to south over approximately $130 \mathrm{~m}$ (Tivey et al., 2005; Ferrini et al., 2008). Dominant minerals present in KM deposits include cubic cubanite, chalcopyrite, and wurtzite, with pyrite and marcasite more prevalent in deposit exteriors (Tivey, pers. comm.). The Tow Cam (TC) vent field $\left(176^{\circ} 08.2^{\prime} \mathrm{W}, 20^{\circ} 19.0^{\prime} \mathrm{S}, 2690-2728 \mathrm{~m}\right)$ is located $29-\mathrm{km}$ to the south of 
KM and is also hosted on basaltic substrate (Ferrini et al., 2008). A newly discovered site, named Tahi Moana (TaM) $\left(176^{\circ} 10.5^{\prime} \mathrm{W}, 20^{\circ} 40.3^{\prime} \mathrm{S}\right)$, was also sampled. This site is also basalt-hosted and is at a depth of 2214-2260 m. Fifty kilometers to the south of TC (and $\sim 10 \mathrm{~km}$ from Tahi Moana) where spreading rate, crustal thickness and depth have intermediate values, is the $\mathrm{ABE}$ vent field $\left(176^{\circ} 11.5^{\prime} \mathrm{W}, 20^{\circ} 45.8^{\prime} \mathrm{S} ; 2104-2163 \mathrm{~m}\right)$. ABE is hosted atop basaltic-andesites (Mottl et al., 2011) and hydrothermal activity here extends $600 \mathrm{~m}$ along the NE-SW trending fault that dominates this region (Ferrini et al., 2008). Dominant minerals in ABE deposits include chalcopyrite and wurtzite with minor amounts of pyrite and barite, and trace amounts of galena (Tivey, 2007 and Tivey, pers. comm.). Approximately $140 \mathrm{~km}$ south of ABE on the VFR, is the Tui Malila (TuM) $\left(176^{\circ} 34.06^{\prime} \mathrm{W}, 21^{\circ} 59.35^{\prime} \mathrm{S}, 1839-1928 \mathrm{~m}\right)$ vent field (Ferrini et al., 2008). Although TuM is on a different spreading segment than ABE, both vent fields are hosted atop basaltic-andesites and are crosscut by NE-SW faults. Hydrothermal activity at TuM extends approximately $350 \mathrm{~m}$ north-to-south. Twenty-five kilometers south of TuM on the VFR is the Mariner $\left(176^{\circ} 36.09^{\prime} \mathrm{W}, 22^{\circ} 10.82^{\prime} \mathrm{S} ; 1877-1951 \mathrm{~m}\right)$ vent field. Like TuM and ABE, Mariner is hosted on basaltic-andesite, but dacites and rhyolites also lie close to the vents at Mariner (Mottl et al., 2011). Mariner deposits are lined with chalcopyrite, and bornite, with trace amounts of tennentite observed in mid- and exterior layers. Some structures are also barite-rich. Deposits collected from each vent field are summarized in Table 3.2. 
Table 3.2. Hydrothermal deposits collected from the Eastern Lau Spreading Center used for microbial community characterization.

\begin{tabular}{|c|c|c|c|c|c|c|}
\hline Sample Name & Rock number & Longitude & Latitude & $\begin{array}{l}\text { Depth } \\
\text { (m) }\end{array}$ & $\begin{array}{c}\text { \# of } \\
\text { bacterial } \\
\text { pyrotags }\end{array}$ & $\begin{array}{c}\text { \# of } \\
\text { archaeal } \\
\text { pyrotags }\end{array}$ \\
\hline KM-1 & J2-434-1-R1 & $176.13362 \mathrm{~W}$ & $20.054029 \mathrm{~S}$ & 2622 & - & 3368 \\
\hline KM-2 & $\mathrm{J} 2-434-2-\mathrm{R} 1$ & $176.133639 \mathrm{~W}$ & $20.053795 \mathrm{~S}$ & 2621.9 & 5932 & 4669 \\
\hline KM-35 & $\mathrm{J} 2-436-2-\mathrm{R} 1$ & $176.133515 \mathrm{~W}$ & $20.054093 \mathrm{~S}$ & 2616.9 & 11242 & 4318 \\
\hline KM-36 & $\mathrm{J} 2-436-4-\mathrm{R} 1$ & $176.133763 \mathrm{~W}$ & $20.053234 \mathrm{~S}$ & 2611 & 8159 & 6239 \\
\hline TC-26 & $\mathrm{J} 2-443-6-\mathrm{R} 2$ & $176.136593 \mathrm{~W}$ & $20.316307 \mathrm{~S}$ & 2721 & 7061 & 1159 \\
\hline TC-27 & J2-443-4-R1 & $176.136554 \mathrm{~W}$ & $20.316497 \mathrm{~S}$ & 2717 & - & 4023 \\
\hline TC-46 & $\mathrm{J} 2-443-2-\mathrm{R} 1$ & $176.136516 \mathrm{~W}$ & $20.316524 \mathrm{~S}$ & 2710 & 7757 & 2801 \\
\hline TC-61 & $\mathrm{J} 2-451-1-\mathrm{R} 1$ & $176.13665 \mathrm{~W}$ & $20.316316 \mathrm{~S}$ & 2717 & 11201 & 1694 \\
\hline TC-62 & $\mathrm{J} 2-451-3-\mathrm{R} 1$ & $176.136459 \mathrm{~W}$ & $20.316497 \mathrm{~S}$ & 2709.7 & 9842 & 4035 \\
\hline TaM-29 & $\mathrm{J} 2-445-5-\mathrm{R} 1$ & $176.180099 \mathrm{~W}$ & $20.673876 \mathrm{~S}$ & 2258 & - & 2876 \\
\hline TaM-47 & $\mathrm{J} 2-444-22-\mathrm{R} 1$ & $176.183584 \mathrm{~W}$ & $20.684679 \mathrm{~S}$ & 2214.3 & 8688 & 5814 \\
\hline TaM-48 & $\mathrm{J} 2-444-23-\mathrm{R} 1$ & $176.18343 \mathrm{~W}$ & $20.684552 \mathrm{~S}$ & 2216.7 & 9108 & 1118 \\
\hline TaM-49 & $\mathrm{J} 2-444-23-\mathrm{R} 2$ & $176.18343 \mathrm{~W}$ & $20.684552 \mathrm{~S}$ & 2216.7 & 6309 & 2836 \\
\hline TaM-50 & $\mathrm{J} 2-444-4-\mathrm{R} 1$ & $176.182643 \mathrm{~W}$ & $20.681743 \mathrm{~S}$ & 2230 & 6907 & 5759 \\
\hline TaM-51 & $\mathrm{J} 2-445-4-\mathrm{R} 1$ & $176.18007 \mathrm{~W}$ & $20.673894 \mathrm{~S}$ & 2258 & 9242 & - \\
\hline TaM-52 & $\mathrm{J} 2-445-6-\mathrm{R} 1$ & $176.180109 \mathrm{~W}$ & $20.673876 \mathrm{~S}$ & 2257 & 11334 & 1710 \\
\hline $\mathrm{ABE}-3$ & $\mathrm{~J} 2-435-1-\mathrm{R} 1$ & $176.190398 \mathrm{~W}$ & $20.761274 \mathrm{~S}$ & 2141 & 4884 & 2863 \\
\hline ABE-5 & $\mathrm{J} 2-435-10-\mathrm{R} 1$ & $176.193079 \mathrm{~W}$ & $20.766332 \mathrm{~S}$ & 2128 & 8607 & 3226 \\
\hline ABE-6 & $\mathrm{J} 2-435-18-\mathrm{R} 1$ & $176.191964 \mathrm{~W}$ & $20.762719 \mathrm{~S}$ & 2127 & 6823 & 3935 \\
\hline ABE-7 & $\mathrm{J} 2-435-9-\mathrm{R} 1$ & $176.192743 \mathrm{~W}$ & $20.766043 \mathrm{~S}$ & 2134 & 7051 & 3731 \\
\hline ABE-33 & $\mathrm{J} 2-435-11-\mathrm{R} 2 \mathrm{a}$ & $176.193098 \mathrm{~W}$ & $20.766214 \mathrm{~S}$ & 2128.6 & 6098 & 4019 \\
\hline ABE-34 & $\mathrm{J} 2-435-20-\mathrm{R} 1$ & $176.190533 \mathrm{~W}$ & $20.761219 \mathrm{~S}$ & 2163 & 11143 & 2788 \\
\hline TuM- $17^{¥}$ & $\mathrm{~J} 2-442-12-\mathrm{R} 2$ & $176.56885 \mathrm{~W}$ & $21.990663 \mathrm{~S}$ & 1853 & 8490 & 3580 \\
\hline TuM-21 $1^{¥}$ & $\mathrm{~J} 2-442-10-\mathrm{R} 1$ & $176.56885 \mathrm{~W}$ & $21.990699 \mathrm{~S}$ & 1855 & 10875 & - \\
\hline TuM-30 $0^{\dagger}$ & $\mathrm{J} 2-447-4-\mathrm{R} 1$ & $176.569082 \mathrm{~W}$ & $21.99059 \mathrm{~S}$ & 1842 & 10078 & 4799 \\
\hline TuM-31 ${ }^{\dagger}$ & $\mathrm{J} 2-447-4-\mathrm{R} 1$ & $176.569082 \mathrm{~W}$ & $21.99059 \mathrm{~S}$ & 1842 & - & 3740 \\
\hline Mariner-12 & $\mathrm{J} 2-437-7-\mathrm{R} 1$ & $176.600977 \mathrm{~W}$ & $22.180414 \mathrm{~S}$ & 1919.2 & 7715 & 5085 \\
\hline Mariner-14 & J2- 439-3-R1 & $176.601782 \mathrm{~W}$ & $22.18045 \mathrm{~S}$ & 1919 & 12136 & 2967 \\
\hline Mariner-15 & J2- 439-13-R2 & $176.601248 \mathrm{~W}$ & $22.180089 \mathrm{~S}$ & 1918.1 & 7626 & 1321 \\
\hline Mariner-37 & J2-437-10-R1 & $176.60119 \mathrm{~W}$ & $22.179953 \mathrm{~S}$ & 1911 & - & 717 \\
\hline Mariner-38 & J2-437-14-R1 & $176.601045 \mathrm{~W}$ & $22.179989 \mathrm{~S}$ & 1912 & - & 3033 \\
\hline Mariner-39 & $\mathrm{J} 2-437-16-\mathrm{R} 1$ & $176.60087 \mathrm{~W}$ & $22.180107 \mathrm{~S}$ & 1917 & 8577 & 3151 \\
\hline Mariner-40 & $\mathrm{J} 2-437-3-\mathrm{R} 2$ & $176.601743 \mathrm{~W}$ & $22.180558 \mathrm{~S}$ & 1922.9 & 7694 & 443 \\
\hline Mariner-42 & $\mathrm{J} 2-439-5-\mathrm{R} 1$ & $176.600928 \mathrm{~W}$ & $22.180107 \mathrm{~S}$ & 1914 & 8553 & 412 \\
\hline Mariner-58 & $\mathrm{J} 2-448-4-\mathrm{R} 1$ & $176.601704 \mathrm{~W}$ & $22.18073 \mathrm{~S}$ & 1921 & 7682 & 1086 \\
\hline Mariner-59 & $\mathrm{J} 2-448-9-\mathrm{R} 1$ & $176.601966 \mathrm{~W}$ & $22.180612 \mathrm{~S}$ & 1925.5 & 21728 & 962 \\
\hline
\end{tabular}

${ }^{\ddagger}$ Indicates samples that were collected from the same structure at different times.

${ }^{\dagger}$ Indicates sub-samples that were collected from the same sample. 


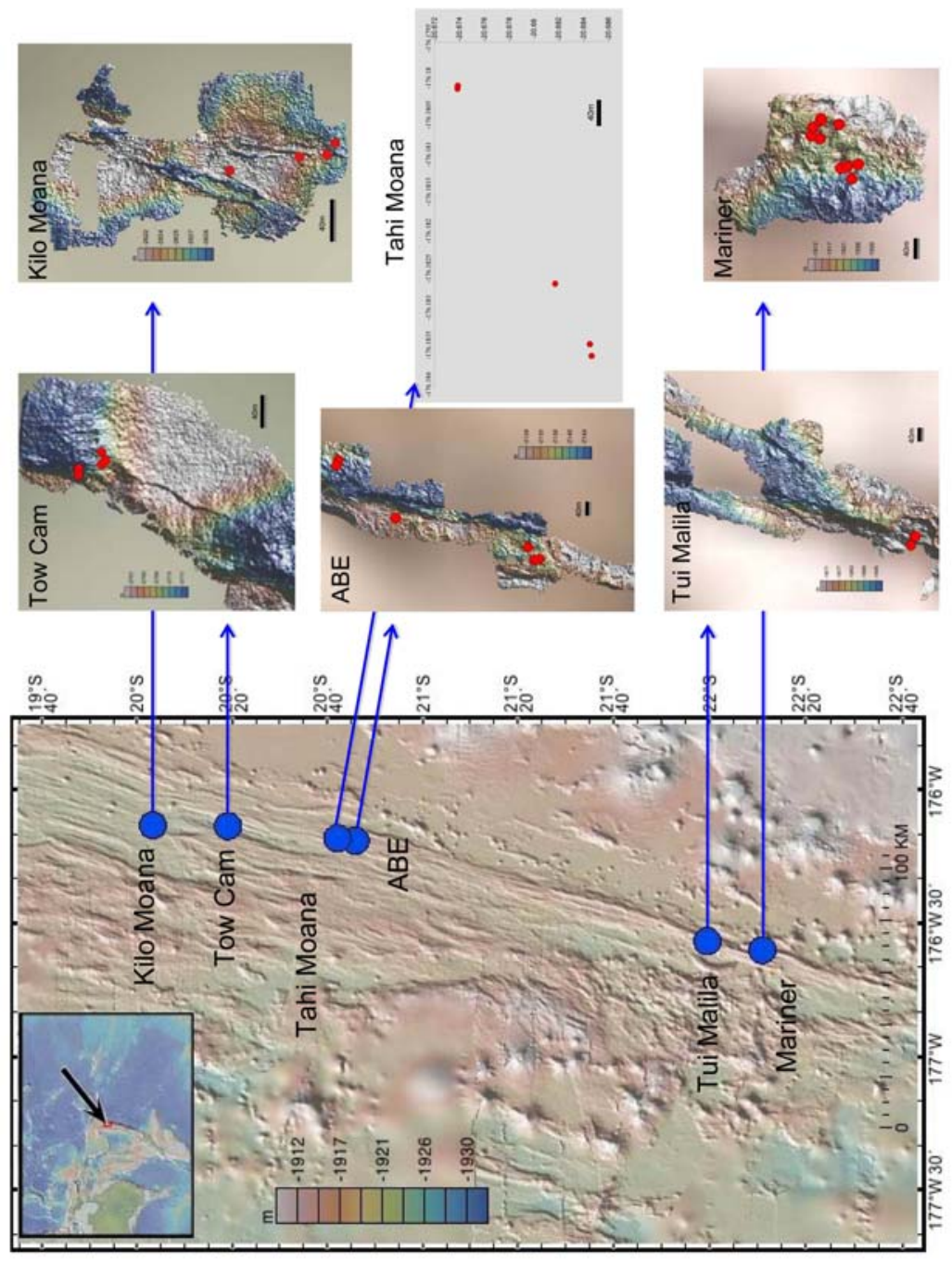

Figure 3.2. Location of deposits collected from each hydrothermal vent field along the Eastern Lau Spreading Center. 
DNA extraction, pyrosequencing and sequence analysis

DNA was extracted from homogenized samples ( $\approx 1.6-3.2$ grams) using the Ultra Clean Soil DNA Isolation Kit (MoBio Laboratories) as previously described (Reysenbach et al., 2006). Pyrosequencing of the variable region 4 (V4) of the 16S rRNA gene was conducted as previously described (Flores et al., 2011).

Raw sequences were initially processed using the RDP-pyrosequencing pipeline (Cole et al., 2009) where sequences less than 200 bp, containing ambiguous nucleotides (N's), with any mismatches to the forward or reverse primers and with a quality score $<20$ were discarded (Flores et al., 2011). The resulting sequences were filtered using custom perl scripts to include sequences less than $275 \mathrm{bp}$ and $250 \mathrm{bp}$ for Archaea and Bacteria, respectively. Trimmed sequences were then subjected to a pre-classification step using the RDP-classifier (Wang et al., 2007) in which unclassified sequences (not Archaea or Bacteria) or sequences classified to the incorrect domain (e.g., Bacteria in the archaeal data set) were removed. Quality sequences were then aligned and clustered using the SLP/PW-AL pipeline (Huse et al., 2010) at a 97\% similarity cutoff. The resulting cluster files were converted to a format suitable for the RDP-pipeline to generate rarefaction curves (Colwell and Coddington, 1994) and Chaol richness estimators (Chao and Bunge, 2002) for each sample. Taxonomic classifications were assigned as previously described (Flores et al., 2011) for representative sequences of each cluster.

Pyrosequencing data was analyzed using a combination of OTU-based (BrayCurtis, Sørensen) and phylogeny-based (UniFrac) (Lozupone et al., 2006; Hamady et 
al., 2010) beta-diversity metrics as previously described (Flores et al., 2011). Similarity and distance matrices were visualized using non-metric multi-dimensional scaling (MDS), and tested for significance using ANOSIM with PRIMER v6 (Clarke and Gorley, 2006). Only the Bray-Curtis results are presented.

In addition to the routine denoising efforts described above, the archaeal libraries of four deposits were processed using a recently described AmpliconNoise denoising pipeline (Quince et al., 2011). Comparison of the denoising results for the four libraries with and without AmpliconNoise is shown in Table 3.3.

\section{Results}

\section{Bacterial community composition}

A total of 268,542 high-quality partial $16 \mathrm{~S}$ rRNA gene sequences were generated from the 30 hydrothermal vent samples for an average of 8,951 sequences per sample (4,884-21,728 sequences per sample) (Table 3.2). From these sequences, 1,699 unique operational taxonomic units (OTUs) (97\% sequence similarity, 79-400 OTUs per sample) were identified with $42 \%$ (715) being singleton OTUs (Figure 3.3). The most abundant OTU (20.24\% of all sequences) was related to Sulfurovum and was found in all 30 deposits. Nitratifractor (4.20\%), Desulfobulbus (3.02\%) and Hippea $(0.47 \%)$ were the only other OTUs observed in all deposits. Rarefaction analysis (Figure 3.4) and Chao1 richness estimators (Figure 3.3) revealed that more bacterial 
diversity may exist for many of the samples surveyed. Bacterial diversity was also generally higher than archaeal diversity for most samples (Figure 3.5).

Table 3.3. Results of AmpliconNoise analysis of four archaeal pyrosequencing libraries from vent deposits of the Eastern Lau Spreading Center. Sequences were put through the AmpliconNoise program as described by Quince et al., (2011) without removal of potential chimeras with Perseus. Resulting sequences were aligned and clustered using two methods as described by Flores et al. (2011). Results obtained without AmpliconNoise are provided for comparison.

\begin{tabular}{|c|c|c|c|c|c|}
\hline \multirow[b]{2}{*}{ Sample } & \multirow[b]{2}{*}{$\begin{array}{c}\# \text { of } \\
\text { Sequences }\end{array}$} & \multicolumn{2}{|c|}{$\mathrm{RDP}-95 \%$} & \multicolumn{2}{|c|}{ SLP/PW-AL - 97\% } \\
\hline & & $\begin{array}{c}\text { OTUs } \\
\text { observed }\end{array}$ & $\begin{array}{c}\text { Chao1 } \\
(95 \% \text { CI) }\end{array}$ & $\begin{array}{c}\text { OTUs } \\
\text { observed }\end{array}$ & $\begin{array}{l}\text { Chao1 } \\
(95 \% \mathrm{CI})\end{array}$ \\
\hline Lau09-15 (AN) ${ }^{\S}$ & 1455 & 18 & $\begin{array}{c}19 \\
(18-29)\end{array}$ & 17 & $\begin{array}{c}19 \\
(17-32)\end{array}$ \\
\hline Lau09-15 & $1321^{*}$ & 25 & $\begin{array}{c}30 \\
(26-57)\end{array}$ & 19 & $\begin{array}{c}21 \\
(19-34)\end{array}$ \\
\hline Lau09-33 (AN) & 4402 & 44 & $\begin{array}{c}50 \\
(45-71)\end{array}$ & 48 & $\begin{array}{c}55 \\
(50-80)\end{array}$ \\
\hline Lau09-33 & 4019 & 60 & $\begin{array}{c}67 \\
(62-88)\end{array}$ & 50 & $\begin{array}{c}57 \\
(52-78)\end{array}$ \\
\hline Lau09-34 (AN) & 2657 & 78 & $\begin{array}{c}122 \\
(95-188)\end{array}$ & 87 & $\begin{array}{c}141 \\
(110-216)\end{array}$ \\
\hline Lau09-34 & 2788 & 105 & $\begin{array}{c}144 \\
(122-194)\end{array}$ & 89 & $\begin{array}{c}136 \\
(109-201)\end{array}$ \\
\hline Lau09-35 (AN) & 4158 & 27 & $\begin{array}{c}35 \\
(28-70)\end{array}$ & 31 & $\begin{array}{c}43 \\
(34-85)\end{array}$ \\
\hline Lau09-35 & $4318^{+}$ & 39 & $\begin{array}{c}46 \\
(41-71)\end{array}$ & 34 & $\begin{array}{c}56 \\
(40-121)\end{array}$ \\
\hline \multicolumn{6}{|c|}{$\begin{array}{l}{ }^{\S} \text { AmpliconNoise } \\
{ }^{*} 59 \text { of these sequences were not in the } 1455 \text { sequences resulting from the AmpliconNoise analysis ( } 52 \text { of } \\
59 \text { are unique). From these } 59 \text { sequences, four singleton OTUs were generated within the sample but only } \\
\text { one of these OTUs was not observed in another sample. } \\
+216 \text { of these sequences were not in the } 4158 \text { sequences resulting from the AmpliconNoise analysis (174 } \\
\text { of } 216 \text { are unique). From these } 216 \text { sequences, only three unique OTUs were observed. }\end{array}$} \\
\hline
\end{tabular}


With the exception of KM-2 and Mariner-12, the majority $(>50 \%)$ of sequences detected in all the samples were classified as Epsilonproteobacteria (Figure 3.6a). Caminibacter, Lebetimonas, Nautilia, Nitratifractor, Nitratiruptor, Sulfurimonas and Sulfurovum were associated with most deposits although the dominant genera varied between samples and in the case of Mariner, by vent field, as the Nautilia were more prevalent here (Figure 3.6a). Other taxa commonly observed included thermophilic and non-thermophilic lineages such as the Alphaproteobacteria, Aquificales, Caldisericia, Chloroflexi, Deferribacteres, Deinococcus/Thermus, Deltaproteobacteria, Firmicutes, Gammaproteobacteria, Thermodesulfobacteria and Thermotogae (Figure 3.6b). 


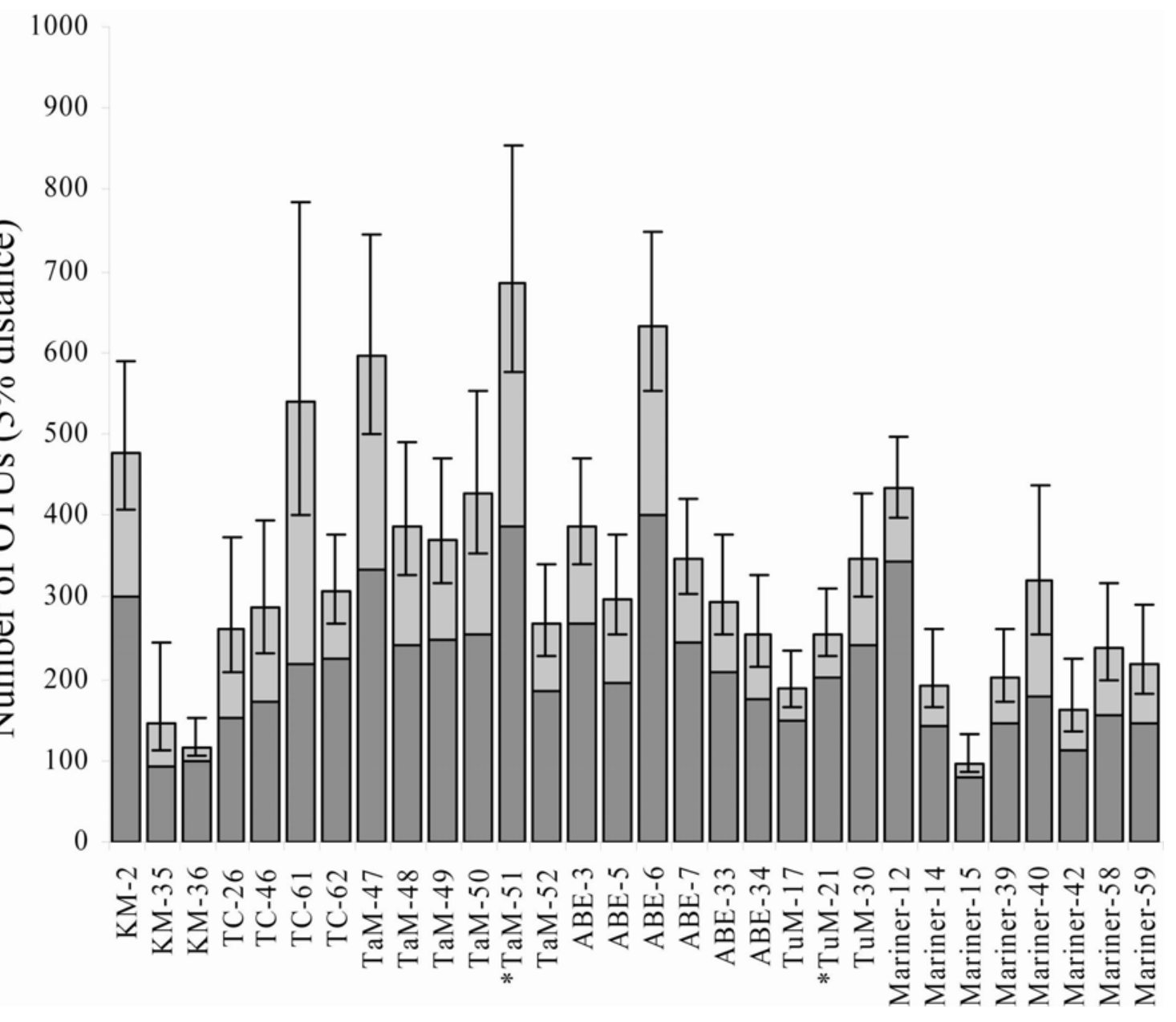

Figure 3.3. OTU richness (dark grey bars) and Chaol diversity estimates (light grey bars) of bacterial diversity for each vent deposits characterized from the Eastern Lau Spreading Center. Error bars indicate the $95 \%$ confidence interval of the Chao 1 estimator. Asterisks denote samples for which corresponding archaeal data was not obtained. 

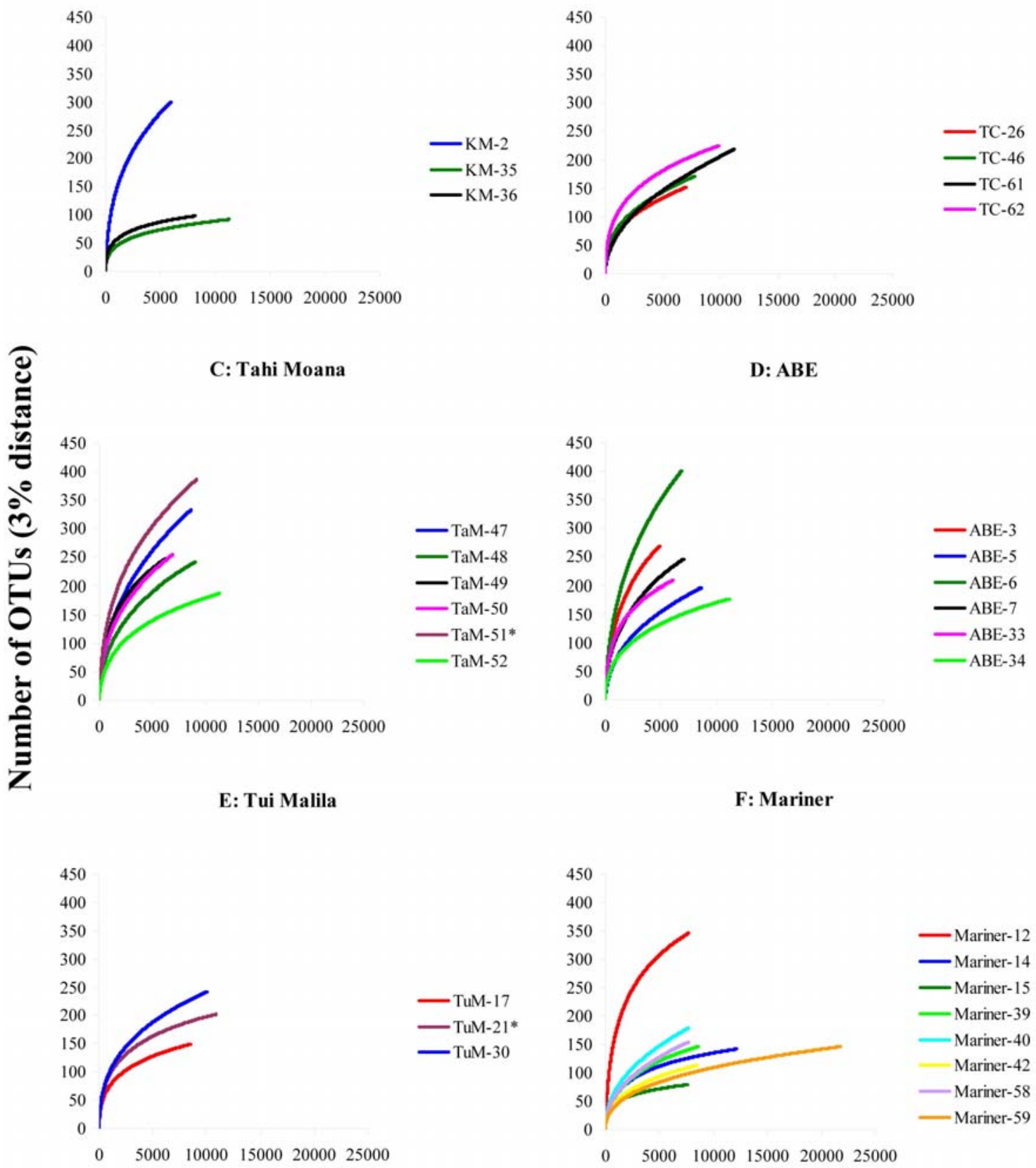

\section{Number of tag sequences}

Figure 3.4. Rarefaction curves for bacterial communities of hydrothermal vent deposits from different vent fields along the Eastern Lau Spreading Center. 


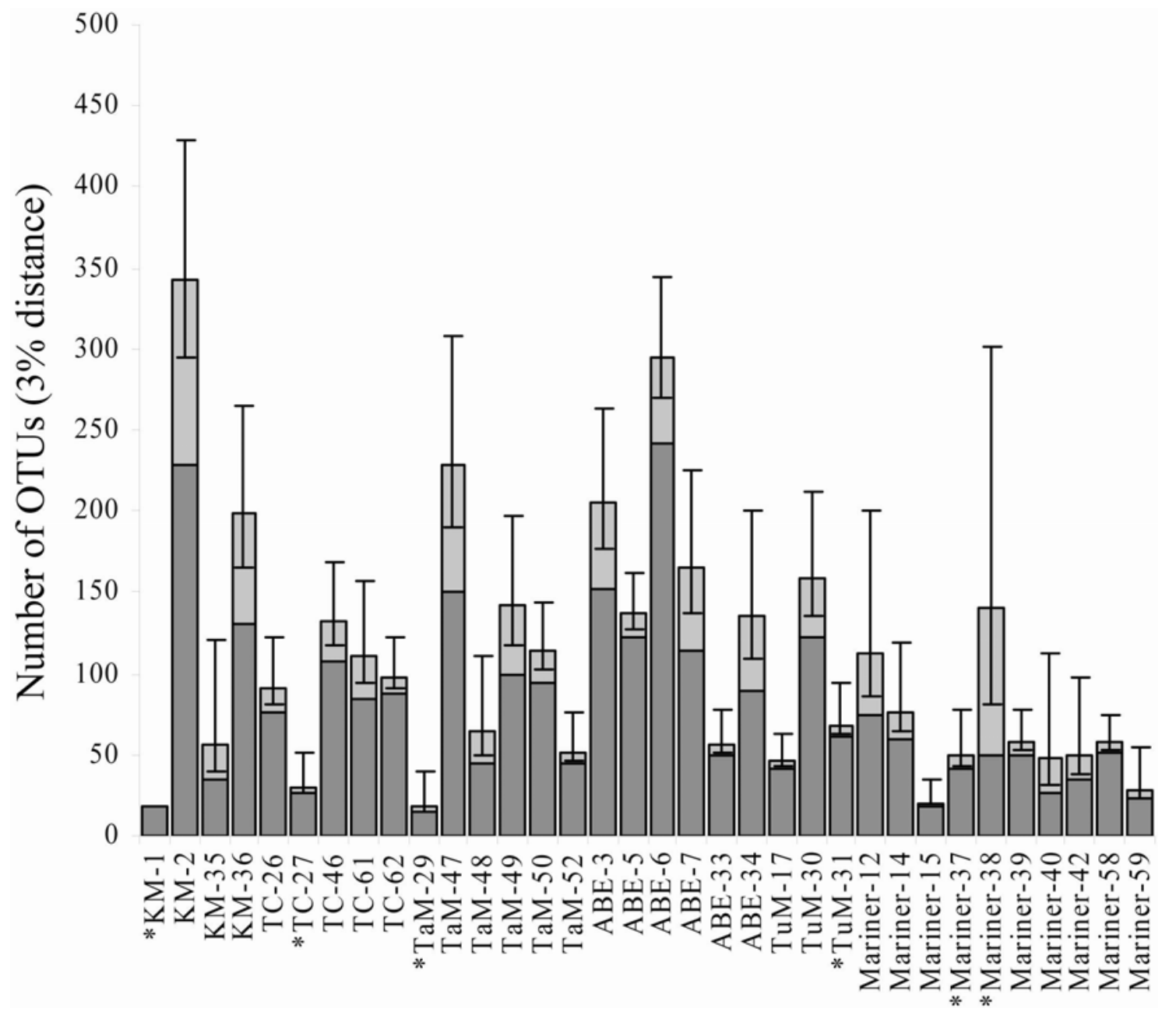

Figure 3.5. OTU richness (dark grey bars) and Chaol diversity estimates (light grey bars) of archaeal diversity for each vent deposits characterized from the Eastern Lau Spreading Center. Error bars indicate the $95 \%$ confidence interval of the Chao1 estimator. Asterisks denote samples for which corresponding bacterial data was not obtained. 

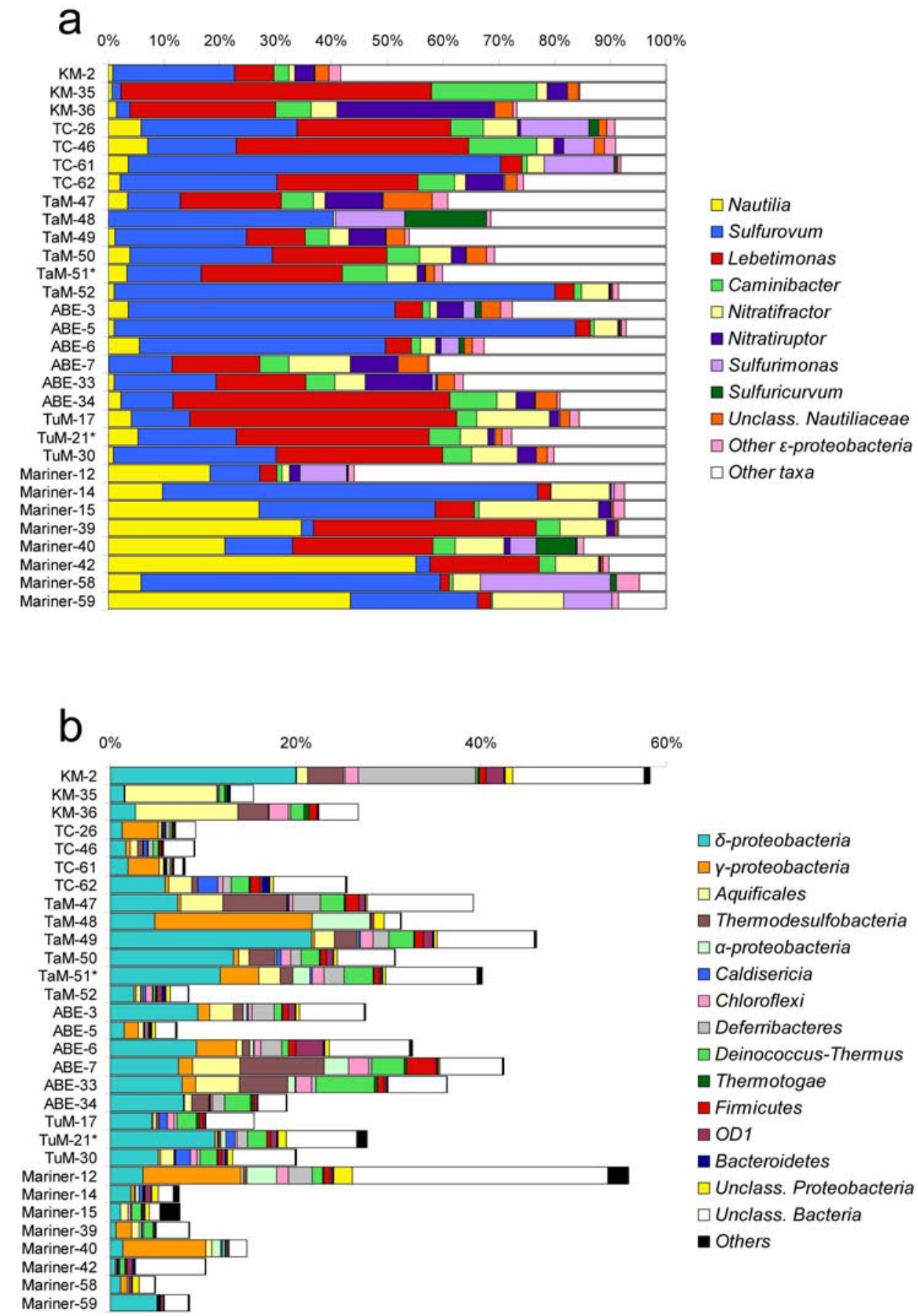

Figure 3.6. Relative abundance of epsilonproteobacterial genera (a) and other bacterial taxa (b) observed in hydrothermal vent deposits collected from the Eastern Lau Spreading Center. Asterisks denote deposits for which corresponding archaeal data was not obtained. 
Interfield bacterial community comparisons

Results of a one-way ANOSIM test comparing the bacterial communities from the different vent fields showed that the communities associated with Mariner deposits were distinct as all pairwise comparisons were statistically significant $(\mathrm{P}<0.05)$ (Table 3.4). Only one other pairwise comparison (KM vs. TC) was statistically significant ( $\mathrm{R}$ $=0.463, \mathrm{P}=0.029)$. Non-metric multidimensional scaling (MDS) plots support these observations as communities from Mariner cluster together to the exclusion of deposits from other vent fields, and the communities from KM do not overlap with those from TC (Figure 3.7a). Overall, these results indicate that the bacterial communities from Mariner are different from the other vent fields in the Lau Basin.

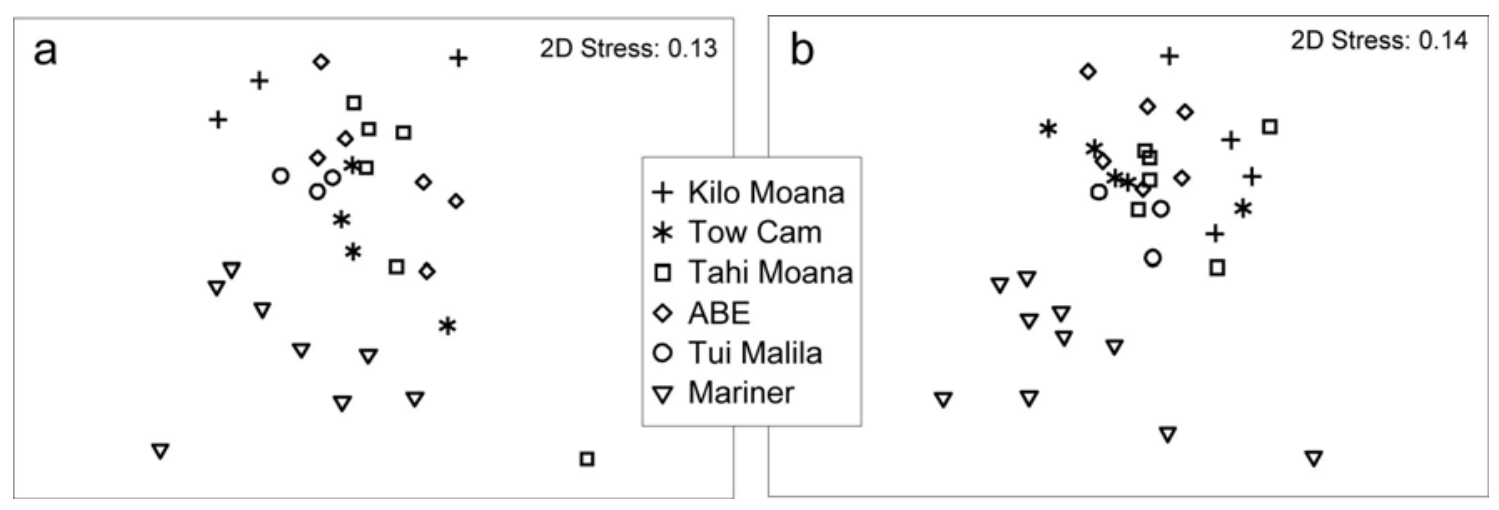

Figure 3.7. Non-metric multidimensional scaling plots (MDS) based on Bray-Curtis similarities of the bacterial (a) and archaeal (b) communities of hydrothermal vent deposits from the Eastern Lau Spreading Center. 
Table 3.4. Results of pairwise comparisons of bacterial communities from different vent fields along the Eastern Lau Spreading Center using the ANOSIM test in Primer v6. $R$ - and p-values (parentheses) are shown for each comparison. Values in italics indicate those that are statistically significant at a $\mathrm{p}$-value $\leq 0.05$.

\begin{tabular}{|c|c|c|c|c|c|}
\hline & Kilo Moana & Tow Cam & Tahi Moana & $\mathrm{ABE}$ & Tui Malila \\
\hline \multicolumn{6}{|l|}{ Kilo Moana } \\
\hline Tow Cam & $\begin{array}{c}0.463 \\
(0.029)\end{array}$ & & & & \\
\hline Tahi Moana & $\begin{array}{l}0.204 \\
(0.19)\end{array}$ & $\begin{array}{c}0.159 \\
(0.148)\end{array}$ & & & \\
\hline $\mathrm{ABE}$ & $\begin{array}{c}0.364 \\
(0.083)\end{array}$ & $\begin{array}{c}0.194 \\
(0.114)\end{array}$ & $\begin{array}{l}-0.039 \\
(0.645)\end{array}$ & & \\
\hline Tui Malila & $\begin{array}{c}0.37 \\
(0.10)\end{array}$ & $\begin{array}{c}0.537 \\
(0.057)\end{array}$ & $\begin{array}{c}0.031 \\
(0.405)\end{array}$ & $\begin{array}{c}0.154 \\
(0.226)\end{array}$ & \\
\hline Mariner & $\begin{array}{c}0.806 \\
(0.006)\end{array}$ & $\begin{array}{c}0.381 \\
(0.012)\end{array}$ & $\begin{array}{c}0.463 \\
(0.001)\end{array}$ & $\begin{array}{c}0.594 \\
(0.0007)\end{array}$ & $\begin{array}{c}0.411 \\
(0.048)\end{array}$ \\
\hline Summary & $6 / 15$ & rwise comp & ns are statistice & ignificant & 05) \\
\hline
\end{tabular}

Archaeal community composition

The archaeal communities of 34 vent deposits were characterized generating 104,277 partial 16S rRNA gene sequences (412-6,239 sequences per sample) (Table 3.2). A total of 656 unique OTUs (97\% sequence similarity, 15-242 OTUs per sample) were identified with approximately $17 \%$ (114) containing only one sequence (Figure 3.5). The single most abundant OTU (17.6\% of all sequences) was classified as Thermofilum and was found in 28 of 34 deposits. The six deposits that did not contain this OTU were all from the Mariner vent field. Thermococcus (13.2\% of all sequences) was the only OTU detected in all deposits. Unlike for the bacterial communities, much 
of the diversity of the archaeal communities appeared to be captured as many of the rarefactions curves were asymptotic (Figures 3.8).

A: Kilo Moana

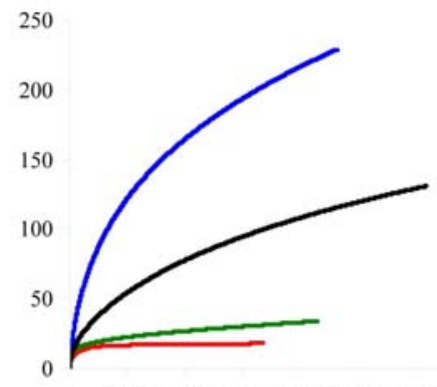

$0 \quad 1000200030004000500060007000$
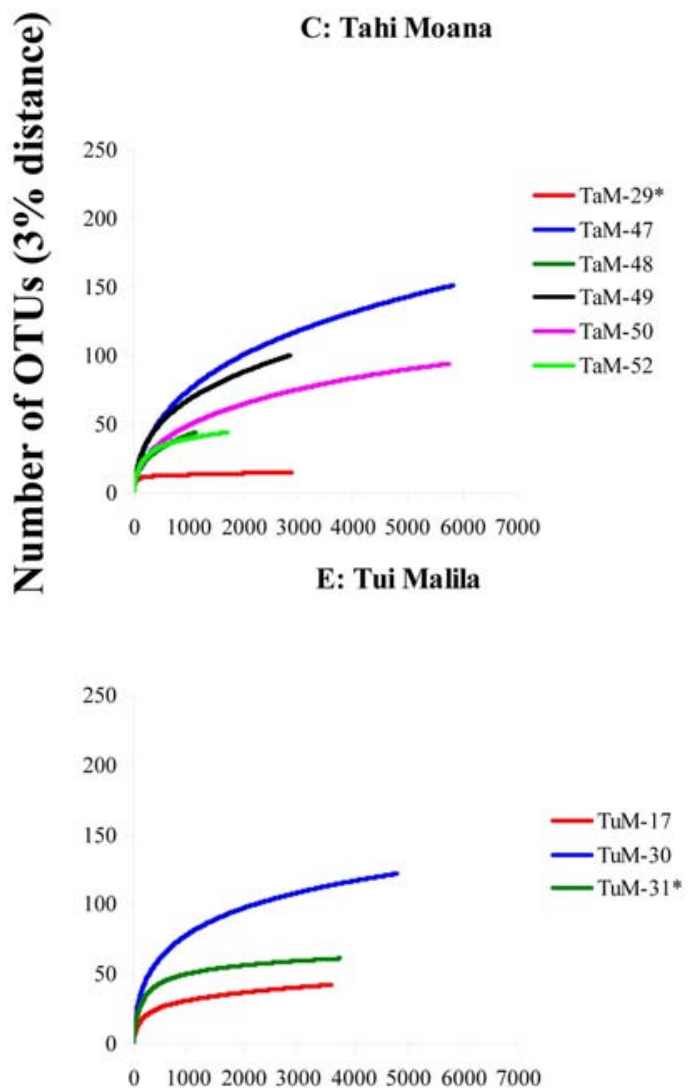

B: Tow Cam

250

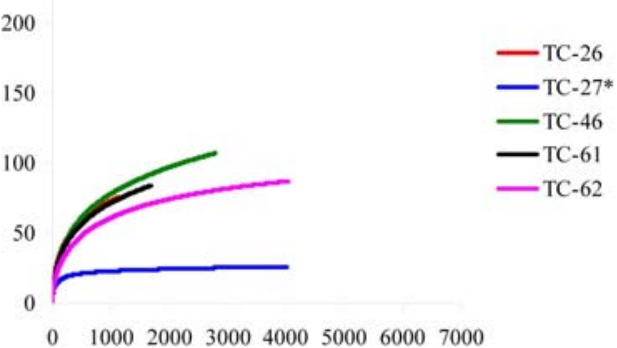

D: $\mathbf{A B E}$

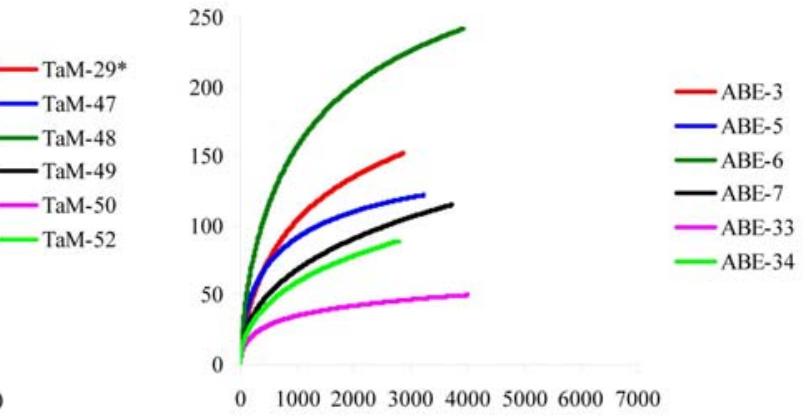

F: Mariner

\section{Number of tag sequences}

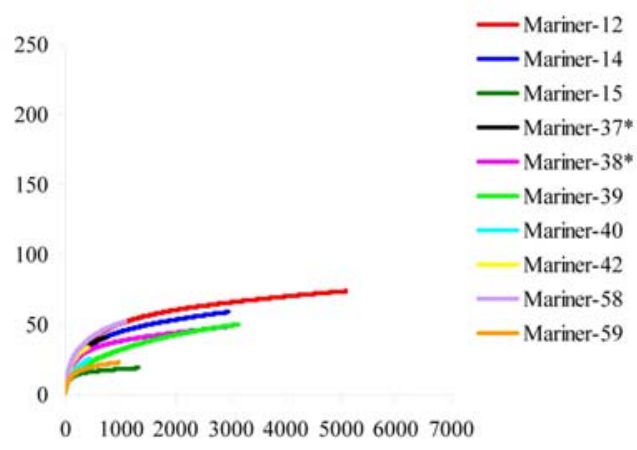

eques

Figure 3.8. Rarefaction curves for archaeal communities of hydrothermal vent deposits from different vent fields along the Eastern Lau Spreading Center. 
The Crenarchaeota were most abundant in 24 of the 34 deposits (Figure 3.9a). Within the Crenarchaeota, the Desulfurococcaceae, Thermofilaceae and Thermoproteaceae were abundant in most deposits except those from Mariner. Deposits from Mariner had, on average, a lower proportion of crenarchaeotal sequences than the other vent fields but did harbor some unique lineages not commonly observed in marine hydrothermal environments (Figure 3.9a, b). For example, one deposit from Mariner, Mariner-12, had a significant number of Caldisphaeraceae. There were many crenarchaeotal sequences that could not be classified beyond the class (Thermoprotei) or order (Desulfurococcales and Thermoproteales) levels (Figure 3.9a; unclassified Crenarchaeota). Of the ten samples not dominated by Crenarchaeota, nine had mostly euryarchaeotal sequences (mostly in the Thermococcaceae, DHVE2 and Archaeoglobaceae) and one had over $40 \%$ nanoarchaeotal sequences. The Thermococcaceae dominated most deposits from Mariner (Figure 3.9b). Methanogens (Methanocaldococcaceae and Methanococcaceae) were relatively rare in most deposits, especially those from Mariner (Figure 3.9b). Several unclassified lineages like the DHVE5 and the unclassified Euryarchaeota A (Flores et al., 2011) were also frequently detected (Figure 3.9a). The Nanoarchaeota and Korarchaeota were observed in 27 and 24 of the 34 deposits, respectively. 

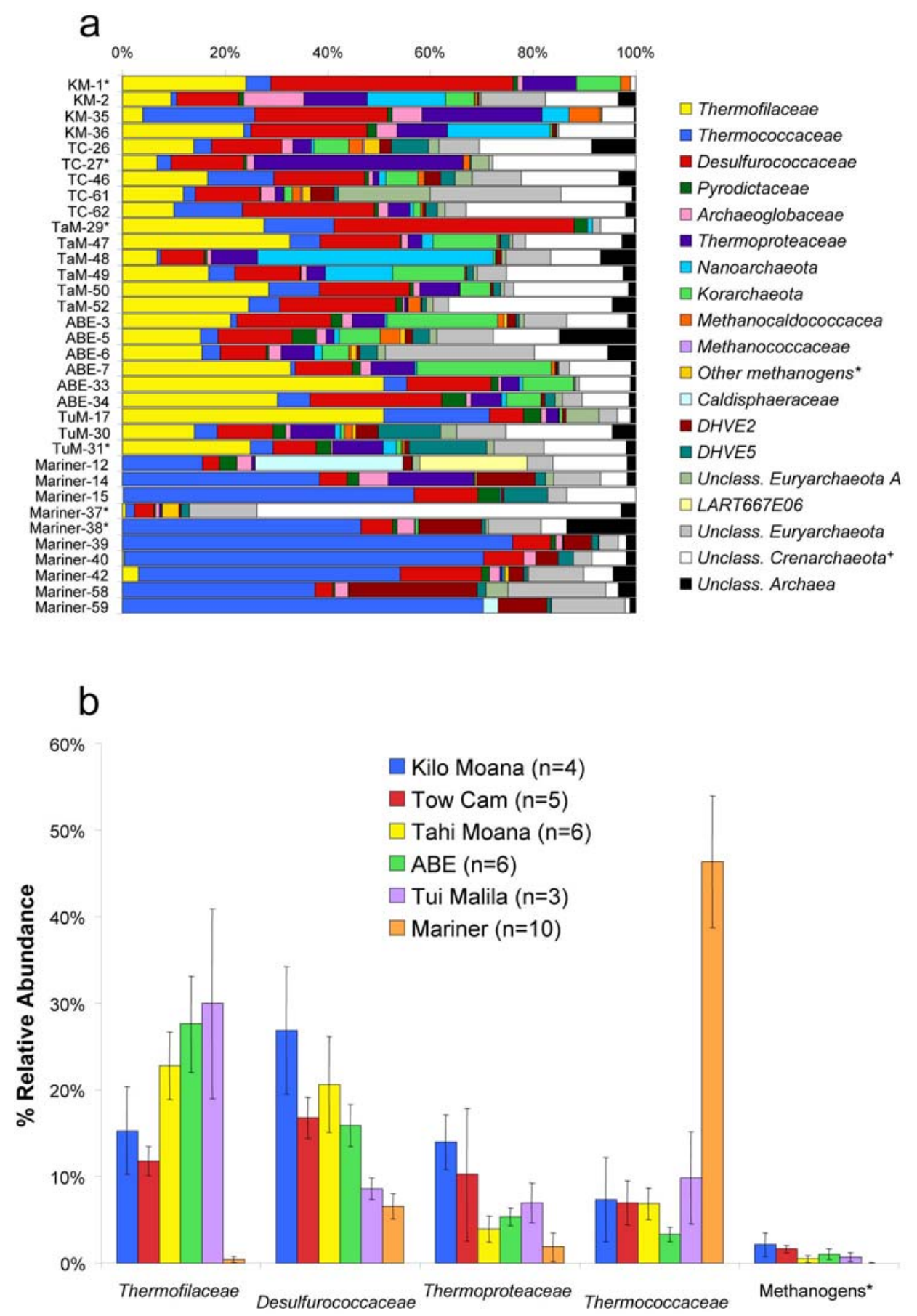

Figure 3.9. Relative abundance of archaeal families (a) observed in individual deposits and average abundance of discriminating archaeal families (b) observed in deposits within individual vent fields along the Eastern Lau Spreading Center. Asterisks in a denote deposits for which corresponding bacterial data was not obtained. Error bars in $\mathbf{b}$ indicate \pm 1 standard error of the mean (SEM). 
Interfield archaeal community comparisons

As was observed with the bacterial ANOSIM test, all pairwise comparisons involving Mariner were statistically significant $(\mathrm{P}<0.05)$ (Table $3.5 \&$ Figure $3.7 \mathrm{~b})$. Unlike with the bacterial communities, however, several other pairwise comparisons including all involving $\mathrm{ABE}$ and 4/5 involving $\mathrm{KM}$ were also statistically significant (P $<0.05$ ) (Table 3.5). Overall, these results suggest that the archaeal communities from the six vent fields, particularly KM, ABE and Mariner, are unique.

Table 3.5. Results of pairwise comparisons of archaeal communities from different vent fields along the Eastern Lau Spreading Center using the ANOSIM test in Primer v6. $R$ - and p-values (parentheses) are shown for each comparison. Values in italics indicate those that are statistically significant at a $p$-value $\leq 0.05$.

\begin{tabular}{|c|c|c|c|c|c|}
\hline & Kilo Moana & Tow Cam & Tahi Moana & $\mathrm{ABE}$ & Tui Malila \\
\hline \multicolumn{6}{|l|}{ Kilo Moana } \\
\hline Tow Cam & $\begin{array}{c}0.444 \\
(0.032)\end{array}$ & & & & \\
\hline Tahi Moana & $\begin{array}{c}0.087 \\
(0.238)\end{array}$ & $\begin{array}{c}0.077 \\
(0.169)\end{array}$ & & & \\
\hline $\mathrm{ABE}$ & $\begin{array}{l}0.563 \\
(0.01)\end{array}$ & $\begin{array}{c}0.416 \\
(0.002)\end{array}$ & $\begin{array}{c}0.146 \\
(0.041)\end{array}$ & & \\
\hline Tui Malila & $\begin{array}{c}0.463 \\
(0.029)\end{array}$ & $\begin{array}{c}0.395 \\
(0.071)\end{array}$ & $\begin{array}{c}0.179 \\
(0.214)\end{array}$ & $\begin{array}{c}0.346 \\
(0.048)\end{array}$ & \\
\hline Mariner & $\begin{array}{c}0.734 \\
(0.002)\end{array}$ & $\begin{array}{c}0.591 \\
(0.001)\end{array}$ & $\begin{array}{c}0.598 \\
(0.0001)\end{array}$ & $\begin{array}{c}0.699 \\
(0.0001)\end{array}$ & $\begin{array}{c}0.422 \\
(0.045)\end{array}$ \\
\hline Summary & $11 / 1$ & irwise comp & ons are statistic & significant & $.05)$ \\
\hline
\end{tabular}




\section{Discussion}

The microbial communities of active hydrothermal vent deposits from six vent fields located along the ELSC were characterized using bar-coded pyrosequencing in order to broaden our understanding of the spatial diversity of deep-sea vent microbial communities. The results presented provide valuable insight into the diversity of microorganisms that inhabit hydrothermal vent deposits and begin to illustrate the impact different geologic settings can have on microbial community composition and structure.

\section{Bacterial communities}

Overall, the bacterial communities associated with active hydrothermal deposits in the Lau Basin resemble those from other hydrothermal vent sites with diverse Epsilonproteobacteria dominating most deposits. Epsilonproteobacteria are considered the most ecologically important microorganisms in marine hydrothermal environments where they are involved in carbon, nitrogen and sulfur cycling at low and high temperatures, and in both oxic and anoxic habitats (Campbell et al., 2006). Most of the deposits had a mix of mesophilic (Sulfurovum and Nitratifractor) and thermophilic (Lebetimonas, Caminibacter and Nautilia) genera illustrating the steep thermal gradients that exist in vent deposits (Figure 3.6). The prevalence of Lebetimonas in most deposits, however, was unexpected as our previous work had shown them to be a minor component of the bacterial communities in deposits from the Mid-Atlantic Ridge (MAR) (Flores et al., 2011). Instead, the closely related Caminibacter (both are part of 
the Nautiliaceae) was the dominant genus of Epsilonproteobacteria in most samples from the MAR. While Caminibacter are widespread along the ELSC as well, they are generally lower in abundance than Lebetimonas. The only described Lebetimonas isolate was obtained near the ELSC and is a moderate acidophile capable of oxidizing $\mathrm{H}_{2}$ and reducing sulfur (Takai et al., 2005). Caminibacter are also $\mathrm{H}_{2}$-oxidizers but have been isolated from the East Pacific Rise (EPR) (Alain et al., 2002) and MAR (Miroshnichenko et al., 2004; Voordeckers et al., 2005). While it is possible that classification of Lebetimonas is an artifact of the RDP-classifier, we combined our MAR and ELSC data sets and the dominant Lebetimonas OTU at the ELSC $(11.03 \%$ of all sequences) is not present along the MAR (data not shown). Also, Lebetimonas were not detected in 16S rRNA gene clone libraries from deposits along a different back-arc spreading center also in the western Pacific Ocean (Southern Mariana Trough - SMT) (Kato et al., 2010). In that study, depth was thought to be an important factor in epsilonproteobacterial biogeography. Although our study also covers a depth gradient, the vent fields examined here are deeper than those considered by Kato et al. (2010). Overall, these results continue to demonstrate the importance of the Epsilonproteobacteria in bacterial biogeography of deep-sea vents but also provide intriguing areas for future studies as to why certain genera are more prevalent in different geologic and geographic settings.

Besides the Epsilonproteobacteria, genera of Deltaproteobacteria were also frequently abundant in most deposits. One genus observed in all samples, albeit at relatively low numbers, was Hippea. Recently, several novel Hippea species were 
found to be thermoacidophiles similar to the archaeal DHVE2 (Flores et al., in review) (Reysenbach et al., 2006). Acidic habitats are generated in deposits by the conductive cooling of hydrothermal fluids or by diffusion of hydrothermal fluids outwards across the wall of a deposit without any mixing of seawater (Tivey, 2004). Just as the presence of mesophilic and thermophilic Epsilonproteobacteria illustrated the steep temperature gradients in vent deposits, the presence of thermoacidophiles in all deposits highlights the steep pH gradients that also exist in vent deposits.

The statistical differences observed in the bacterial communities from the Mariner deposits are most evident by the shift in the abundance of Nautilia (Figure 3.6a). Nautilia are moderately thermophilic, mixotrophic anaerobes (Campbell et al., 2001; Miroshnichenko et al., 2002; Smith et al., 2008). What distinguishes Nautilia from other thermophilic Epsilonproteobacteria like Caminibacter and Lebetimonas, is their ability to oxidize formate (Campbell et al., 2006). The concentration of formate in fluids from the ELSC is unknown. However the concentration of formate varies as a function of total carbon, the redox state of the fluids and temperature (Seewald et al., 2006). The $\mathrm{CO}_{2}$ concentrations at Mariner are generally three to five times higher than the other vent fields due to active degassing of a subsurface magma chamber which also results in more acidic, metal-rich fluids (Table 3.1) (Mottl et al., 2011). With higher $\mathrm{CO}_{2}$ concentrations in the fluids, formate concentrations may also be higher relative to the other vent fields. Formate is also produced biologically by fermentative Archaea like the DHVE2 (Reysenbach et al., 2006). As total carbon and the DHVE2 are generally more abundant at Mariner, the prevalence of Nautilia here may be related to 
the availability of formate. Interestingly, several species of Thermococcus, which are also abundant at Mariner (see below), have also recently been found to oxidize formate (Kim et al., 2010).

\section{Archaeal communities}

As with the bacterial communities, the archaeal communities of the ELSC are generally similar to other deep-sea hydrothermal vent fields with a rich diversity of thermophilic Euryarchaeota and Crenarchaeota, and the occasional detection of the Korarchaeota and Nanoarchaeota. The abundance of the Crenarchaeota in most deposits (other than Mariner), however, is somewhat unusual as the majority of other $16 \mathrm{~S}$ rRNA gene based studies of vent deposits have typically recovered a higher proportion of euryarchaeotal sequences (e.g., Takai and Horikoshi, 1999; Takai et al., 2001; Schrenk et al., 2003; Kormas et al., 2006; Voordeckers et al., 2008; Nunoura and Takai, 2009). Unfortunately, many crenarchaeotal lineages observed in the deep-sea are uncultivated, and those with cultivated organisms are represented by only one or a few isolates (Boone et al., 2001). As a result, we know relatively little about the physiological and metabolic capabilities of many of the groups we are now detecting. As it is now recognized that Archaea are not just extremophiles, it is possible that some of these groups could occupy lower temperature niches where they compete with mesophilic Bacteria. These observations highlight the need for more targeted cultivation efforts or the use of single cell genomics techniques to help describe many of these novel lineages. 
Regardless of the lack of cultivable diversity, it is clear that the low abundance of Crenarchaeota coupled with the high abundance of Thermococcaceae, discriminates the Mariner communities from the other vent fields (Figures 3.7 and 3.9). Cultivated members of the Thermococcaceae are generally sulfur-reducing heterotrophs (Reysenbach et al., 2002). However, recent genomic analyses of multiple Thermococcus species from different deep-sea hydrothermal environments have revealed several species with the potential to oxidize $\mathrm{CO}$ to $\mathrm{CO}_{2}$ (carboxydotrophy) (Lee et al., 2008; Zivanovic et al., 2009; Vannier et al., 2011). Several Thermococcus species, including one isolated from $\mathrm{KM}$, have also recently been shown to conserve energy through the anaerobic oxidation of formate coupled with $\mathrm{H}_{2}$ production (Kim et al., 2010). As with the Nautilia discussed above, the abundance of Thermococcaceae at Mariner may be related to single-carbon compounds originating from the degassing magma chamber or from other fermentative organisms. Further studies are needed to evaluate the importance of single-carbon compounds in the ecology of this ubiquitous deep-sea archaeon.

The relatively low abundance of methanogens (Methanocaldococcaceae and Methanococcaceae) at all vent fields continues to demonstrate the importance of $\mathrm{H}_{2}$ concentrations in structuring the archaeal communities of deep-sea hydrothermal environments (Takai et al., 2006b; McCollom, 2007; Perner et al., 2007; Takai and Nakamura, 2010; Flores et al., 2011). Recently, we characterized the archaeal communities associated with two vent fields at either end of the spectrum with regards to $\mathrm{H}_{2}$ concentrations and found that methanogens were absent in deposits from the vent 
field with extremely low $\mathrm{H}_{2}$ concentrations while methanogens were abundant when $\mathrm{H}_{2}$ concentrations were high (Flores et al., 2011). Fluids from the vent fields surveyed in this current study all have $\mathrm{H}_{2}$ concentrations that are between these two extremes but are much closer to the low end of the spectrum (Table 3.1). It is therefore not surprising that methanogens were observed at relatively low abundance in these vent fields. Integrating our observations with the known geochemistry of different vent fields should allow for predictions of the occurrence and abundance of methanogens in future studies.

Clear differences in the archaeal communities from deposits within the same vent field were also commonly observed. For example, the archaeal (and bacterial) communities associated with Mariner-12 were very different from any other deposit (Figure 3.9). This same structure was sampled in 2005 and yielded the first obligate thermoacidophile from the deep-sea in pure culture (Reysenbach et al., 2006). Other archaeal lineages identified from the Mariner-12 deposit during our study may also represent novel acidophilic deep-sea lineages. Specifically, the Caldisphaeraceae are a thermoacidophilic crenarchaeotal lineage that has only been cultivated from terrestrial hydrothermal environments (Prokofeva et al., 2000; Itoh et al., 2003; Prokofeva et al., 2009) and, to our knowledge, has not previously been detected in the deep-sea. Also, sequences related to the LART667E06 (DQ451876) clone that hinted at an acidophilic lifestyle of the DHVE2 are closely related to acidophilic Thermoplasmales isolated from terrestrial environments (Reysenbach et al., 2006). Besides Mariner, deposits within other vent fields also varied from one another. For example, the Nanoarchaeota 
were abundant in two samples from TaM (TaM-48, TaM49), while they were relatively rare in the 4 other deposits from this vent field. Other researchers have observed variable communities associated with deposits within a vent field and have attributed it to phase separation of the fluids (Nakagawa et al., 2005d; Nunoura and Takai, 2009). As co-collected fluid samples were not obtained for most of our samples, we do not know if our observations are also related to phase separation. However, fluid temperatures from vent fields in the Lau Basin other than Mariner are well below the two-phase boundary indicating that if phase separation occurred, fluids must have cooled prior to reaching the seafloor (Mottl et al., 2011). Therefore, other factors, like fluid mixing styles, deposit mineralogy and age of the deposit, are likely helping to shape within vent field variability in the archaeal communities.

\section{Conclusion}

Results of this study show that at higher taxonomic levels, the bacterial and archaeal communities of active hydrothermal deposits from the ELSC are similar to those from other vent fields. However, at finer taxonomic scales differences in the dominant lineages are apparent both between globally distributed vent fields and within vent fields of the ELSC. Whether the global differences are shaped primarily by environmental factors or are due to the island-like nature of vent fields which would promote allopatry remains to be determined. Using this same approach to characterize the communities of several more vent fields from geographically and geologically distinct locations, along with more fine-scale geochemical, mineralogical and 
physiological characterizations will help to disentangle the role of these non-exclusive factors in shaping deep-sea vent microbial biogeography.

\section{Contributions}

My role in this project was to collect and process samples, extract genomic DNA for pyrosequencing, analyze and interpret pyrosequencing data, and to write the manuscript for publication. Pyrosequencing was conducted by Mircea Podar and his laboratory. 


\section{Chapter 4: Hippea jasoniae sp. nov. and Hippea alviniae sp. nov.,}

Thermoacidophilic Deltaproteobacteria Isolated From Deep-Sea Hydrothermal

\section{Vent Deposits.}

Flores, GE, Hunter, RC, Liu, Y and Reysenbach, A-L (in review) International Journal of Systematic and Evolutionary Microbiology.

\section{Summary}

Thirteen novel, obligately anaerobic, thermoacidophilic bacteria were isolated from deep-sea hydrothermal vent sites. Four of the strains, designated EP5-r ${ }^{\mathrm{T}}$, KM1, Mar08-272r ${ }^{\mathrm{T}}$ and Mar08-368r, were selected for metabolic and physiological characterization. With the exception of EP5-r ${ }^{\mathrm{T}}$, all strains were short rods that grew between 40 and $72^{\circ} \mathrm{C}$, with optimal growth at 60 to $65^{\circ} \mathrm{C}$. Strain EP5-r ${ }^{\mathrm{T}}$ was more ovoid in shape and grew between 45 and $75^{\circ} \mathrm{C}$, with optimum at $60^{\circ} \mathrm{C}$. The $\mathrm{pH}$ range for growth of all isolates was between 3.5 and 5.5 (optimum 4.5 to 5.0). Strain Mar08$272 \mathrm{r}^{\mathrm{T}}$ could only grow up to $\mathrm{pH}$ 5.0. Elemental sulfur was required for heterotrophic growth on acetate, succinate, Casamino acids and yeast extract. Strains EP5-r ${ }^{\mathrm{T}}$, Mar08$272 r^{\mathrm{T}}$ and Mar08-368r could also use fumarate, while EP5- ${ }^{\mathrm{T}}, \mathrm{KM} 1$ and Mar08-272 $\mathrm{r}^{\mathrm{T}}$ could also use propionate. All isolates were able to grow chemolithotrophically on $\mathrm{H}_{2}$, $\mathrm{CO}_{2}$, sulfur and vitamins. Phylogenetic analysis of $16 \mathrm{~S}$ rRNA gene sequences placed the isolates within the Desulfurellaceae of the Deltaproteobacteria, with the closest cultured relative being Hippea maritima $\mathrm{MH}_{2}{ }^{\mathrm{T}}$ ( $\sim 95-98 \%$ sequence similarity). 
Phylogenetic analysis also identified several isolates with at least one intervening sequence within the $16 \mathrm{~S}$ rRNA gene. The genomic $\mathrm{G}+\mathrm{C}$ content of strains EP5- ${ }^{\mathrm{T}}$, KM1, Mar08-272 $\mathrm{r}^{\mathrm{T}}$ and Mar08-368r were 37.1, 42.0, 35.6 and $37.9 \mathrm{~mol} \%$, respectively. The new isolates differed most significantly from H. maritima $\mathrm{MH}_{2}{ }^{\mathrm{T}}$ in their phylogenetic placement and in that they are obligate thermoacidophiles. Based on these phylogenetic and phenotypic properties, the following two new species are proposed: Hippea jasoniae sp. nov. Mar08-272 $\mathrm{r}^{\mathrm{T}}$ and Hippea alviniae sp. nov. EP5-r ${ }^{\mathrm{T}}$.

Members of the class Deltaproteobacteria are physiologically diverse with eight described orders and thermophiles isolated from at least three of the orders (Boone et al., 2001). The order Desulfurellales, however, is the only order whose members are exclusively thermophiles. There is one family within this order, the Desulfurellaceae, represented by two genera, Desulfurella and Hippea. Four species of Desulfurella have been formally described from terrestrial thermal environments. All are neutrophiles that grow optimally between 52 to $60^{\circ} \mathrm{C}$, and conserve energy by sulfur or thiosulfate respiration or by pyruvate fermentation (Miroshnichenko et al., 1998). Hippea, on the other hand, is currently represented by one described species, Hippea maritima $\mathrm{MH}_{2}{ }^{\mathrm{T}}$, which was isolated from a shallow marine vent off the coast of Papua New Guinea (Miroshnichenko et al., 1999). H. maritima $\mathrm{MH}_{2}{ }^{\mathrm{T}}$ is neutrophilic to moderately acidophilic ( $\mathrm{pH}$ 5.7-6.5) and requires salt, yeast extract and sulfur for growth. Electron donors used for growth include molecular hydrogen and acetate. On average, $H$. maritima $\mathrm{MH}_{2}{ }^{\mathrm{T}}$ shares $87 \%$ 16S rRNA gene sequence similarity with members of the 
genus Desulfurella. Here, we describe the first deep-sea vent relatives of Hippea, that are phylogenetically distinct and obligately thermoacidophilic.

Enrichment cultures targeting thermoacidophilic microorganisms were initiated from several deep-sea hydrothermal sulfide deposits that were collected with the $\mathrm{HOV}$ Alvin or ROV Jason II during research cruises to the East Pacific Rise (EPR) in 2004 and 2007, the Eastern Lau Spreading Center (ELSC) in 2005 and 2009, the MidAtlantic Ridge (MAR) in 2008 and the Guaymas Basin (GB) in 2009 (Table 4.1). Once shipboard, individual samples were processed and stored anaerobically as previously described (Götz et al., 2002; Moussard et al., 2004; Reysenbach et al., 2006).

The medium used for enrichments was identical to that used by Reysenbach et al. (2006) and was prepared anaerobically under an atmosphere of $\mathrm{N}_{2}: \mathrm{CO}_{2}(80: 20, \mathrm{v} / \mathrm{v}$, $100 \mathrm{kPa}$ ). The $\mathrm{pH}$ was adjusted to 4.5 with sulfuric acid prior to autoclaving at $105^{\circ} \mathrm{C}$ for 1 hour to avoid melting the sulfur. Cysteine or sulfide $\left(0.5 \mathrm{~g} \mathrm{l}^{-1}\right)$ was added as a reducing agent from sterile stock solutions after autoclaving. For initial enrichments, 5 $\mathrm{ml}$ of medium was inoculated with $0.5 \mathrm{ml}$ of sulfide-deposit slurry and incubated at $70^{\circ} \mathrm{C}$. Growth was detected after 2-3 days of incubation. Two different cell morphologies, small cocci $(\sim 1 \mu \mathrm{m}$ in diameter) and short, motile rods $(\sim 1-3 \mu \mathrm{m}$ in length) were observed in most enrichments when viewed using phase-contrast microscopy (Olympus BX60). The cocci were subsequently isolated and identified as Aciduliprofundum spp. (Reysenbach et al., 2006) through 16S rRNA gene sequencing (Chapter 5). Because "Aciduliprofundum" spp. utilize peptides (Reysenbach and Flores, 2008), they were selected against by transferring the enrichments into medium 
lacking yeast extract and peptone but supplemented with acetate $\left(\right.$ as $\mathrm{NaC}_{2} \mathrm{H}_{3} \mathrm{O}_{2} ; 15$ $\mathrm{mM}$ ) and $10 \mathrm{ml}^{-1}$ vitamins (DSMZ medium 141). Pure cultures of the rods were obtained by at least two rounds of dilution to extinction or with the roll-tube method using gelrite. Isolated colonies were small ( $\sim 1-2 \mathrm{~mm}$ in diameter), translucent and spreading. Purity of all isolates was verified by routine observations using phasecontrast microscopy and sequencing of the $16 \mathrm{~S}$ rRNA gene. A total of 13 pure cultures were obtained with six from the MAR, four from ELSC, two from EPR and one from GB (Table 4.1). Upon isolation, cultures were maintained on the acetate/vitamin medium supplemented with $0.01 \%(\mathrm{w} / \mathrm{v})$ yeast extract and grown at $\mathrm{pH} 4.5-5.0$ and $65^{\circ} \mathrm{C}$.

The 16S rRNA gene of each isolate was amplified, purified and sequenced as described previously (Reysenbach et al., 2000). As 906F failed to amplify the $16 \mathrm{~S}$ rRNA gene of the isolates, we used 1100R and 1114F for sequencing instead (Lane, 1991). Nearly complete $16 \mathrm{~S}$ rRNA gene sequences were assembled using the software SeqMan and were compared to the NCBI non-redundant database using BLAST (Altschul et al., 1990). Results of the BLAST search indicated that all 13 isolates were related to the marine thermophile, Hippea maritima $\mathrm{MH}_{2}{ }^{\mathrm{T}}$ (Miroshnichenko et al., 1999). Assembled sequences have been deposited in GenBank under accession numbers FR754496 - FR754508. 
Table 4.1. Location of hydrothermal vent fields where novel thermoacidophilic bacteria were isolated.

\begin{tabular}{|c|c|c|c|c|c|c|}
\hline Strain name & Vent field & $\begin{array}{c}\text { Year } \\
\text { sampled }\end{array}$ & Location & $\begin{array}{l}\text { Depth } \\
(\mathrm{m})\end{array}$ & $\begin{array}{l}\text { Fluid temp. } \\
\qquad\left({ }^{\circ} \mathrm{C}\right)\end{array}$ & $\begin{array}{c}\text { Deposit } \\
\text { type }\end{array}$ \\
\hline Mar08-272r $r^{T}$ & $\begin{array}{c}\text { Lucky Strike - } \\
\text { MAR }^{\mathrm{a}}\end{array}$ & 2008 & $\begin{array}{l}37^{\circ} 17.5240^{\prime} \mathrm{N} \\
32^{\circ} 16.5085^{\prime} \mathrm{W}\end{array}$ & 1624 & 200 & Chimney \\
\hline Mar08-307r & $\begin{array}{c}\text { Lucky Strike - } \\
\text { MAR }\end{array}$ & 2008 & $\begin{array}{l}37^{\circ} 17.5250^{\prime} \mathrm{N} \\
32^{\circ} 16.5058^{\prime} \mathrm{W}\end{array}$ & 1624 & 70 & Flange \\
\hline Mar08-361r & $\begin{array}{c}\text { Lucky Strike - } \\
\text { MAR }\end{array}$ & 2008 & $\begin{array}{l}37^{\circ} 17.4528^{\prime} \mathrm{N} \\
32^{\circ} 16.9161^{\prime} \mathrm{W}\end{array}$ & 1730 & ND & Flange \\
\hline Mar08-368r & $\begin{array}{c}\text { Lucky Strike - } \\
\text { MAR }\end{array}$ & 2008 & $\begin{array}{c}37^{\circ} 17.4998^{\prime} \mathrm{N} \\
32^{\circ} 16.6715^{\prime} \mathrm{W}\end{array}$ & 1721 & 177 & Chimney \\
\hline Mar08-598r & $\mathrm{TAG}^{\mathrm{b}}-\mathrm{MAR}$ & 2008 & $\begin{array}{c}26^{\circ} 8.2078^{\prime} \mathrm{N} \\
44^{\circ} 49.5297^{\prime} \mathrm{W}\end{array}$ & 3621 & $\approx 46(?)$ & Chimney \\
\hline Mar08-641r & TAG - MAR & 2008 & $\begin{array}{c}26^{\circ} 8.2043^{\prime} \mathrm{N} \\
44^{\circ} 49.5283^{\prime} \mathrm{W}\end{array}$ & 3621 & ND & Chimney \\
\hline$E P 5-r^{T}$ & $\begin{array}{c}\text { "A" vent } 9^{\circ} \mathrm{N} \\
-\mathrm{EPR}^{\mathrm{c}}\end{array}$ & 2004 & $\begin{array}{c}9^{\circ} 46.5003^{\prime} \mathrm{N} \\
104^{\circ} 16.8100^{\prime} \mathrm{W}\end{array}$ & 2520 & 240 & Chimney \\
\hline EPR07-159r & $\begin{array}{c}\text { "P" vent } 9^{\circ} \mathrm{N}- \\
\text { EPR }\end{array}$ & 2007 & $\begin{array}{c}9^{\circ} 50.2876^{\prime} \mathrm{N} \\
104^{\circ} 17.4721^{\prime} \mathrm{W}\end{array}$ & 2507 & 365 & Chimney \\
\hline Guay09-253r & Guaymas Basin & 2009 & $\begin{array}{c}27^{\circ} 00.405^{\prime} \mathrm{N} \\
111^{\circ} 24.567^{\prime} \mathrm{W}\end{array}$ & 2007 & 229 & Chimney \\
\hline Lau09-781r & $\begin{array}{l}\text { Mariner - } \\
\text { VFR }^{\mathrm{d}}\end{array}$ & 2009 & $\begin{array}{c}22^{\circ} 11.2751^{\prime} \mathrm{S} \\
176^{\circ} 36.0755^{\prime} \mathrm{W}\end{array}$ & 1919 & ND & Chimney \\
\hline Lau09-1128r & $\begin{array}{l}\text { Tui Malila - } \\
\text { ELSC }^{\mathrm{e}}\end{array}$ & 2009 & $\begin{array}{c}22^{\circ} 0.1708^{\prime} \mathrm{S} \\
176^{\circ} 34.1066^{\prime} \mathrm{W}\end{array}$ & 1883 & ND & Flange \\
\hline KM1 & $\begin{array}{l}\text { Kilo Moana - } \\
\text { ELSC }\end{array}$ & 2005 & $\begin{array}{c}20^{\circ} 3.1827^{\prime} \mathrm{S} \\
176^{\circ} 8.0241^{\prime} \mathrm{W}\end{array}$ & 2619 & 302 & Chimney \\
\hline LR3-DR & NELSC $^{f}$ & 2009 & $\begin{array}{c}15^{\circ} 2.334^{\prime} \mathrm{S} \\
174^{\circ} 17.022^{\prime} \mathrm{W}\end{array}$ & 1530 & 160 & Chimney \\
\hline
\end{tabular}

Organisms in italics were selected for metabolic and physiologic characterization.

$\mathrm{ND}=$ not determined

${ }^{\text {a }}$ Mid-Atlantic Ridge

${ }^{\mathrm{b}}$ Trans-Atlantic Geotraverse

${ }^{\mathrm{c}}$ East Pacific Rise

${ }^{\mathrm{d}}$ Valu Fa Ridge

${ }^{\mathrm{e}}$ Eastern Lau Spreading Center

${ }^{\mathrm{f}}$ North-Eastern Lau Spreading Center

While the 16S rRNA gene sequence similarity between $H$. maritima $\mathrm{MH}_{2}{ }^{\mathrm{T}}$ and the isolates appeared relatively high, several of the isolates had large insertions that were not considered in BLAST and similarity analyses. Importing the sequences into 
ARB (Ludwig et al., 2004) and aligning them according to secondary structure constraints, revealed that many of the isolates had at least one intervening sequence (IVSs) in two distinct regions of their 16S rRNA genes. Isolates Mar08-272 $\mathrm{r}^{\mathrm{T}}$, Mar08307r, Mar08-598r and Mar08-641r had two different IVSs, one beginning at Escherichia coli nucleotide positions 1025 (H1025) and another at 1448 (H1448) (Table 4.2). KM1 had one IVS at H1025, while Mar08-361r and Mar08-368r had one at H1448. No IVSs were detected in LR3-DR, Lau09-781r, Lau09-1128r, EP5-r ${ }^{\mathrm{T}}$, Epr07159r or Guay09-253r. H. maritima $\mathrm{MH}_{2}{ }^{\mathrm{T}}$ had an IVS in a different region of its $16 \mathrm{~S}$ rRNA gene (H184) that was not reported in the initial characterization of this organism (Miroshnichenko et al., 1999). An environmental clone sequence (AM712337), previously detected at Brothers Seamount off the coast of New Zealand, also had two IVSs, one at H184 and another at H1448. Secondary structure predictions of the IVSs were made using mfold (http://mfold.bioinfo.rpi.edu/cgi-bin/rna-form1.cgi) and drawn using XRNA (http://rna.ucsc.edu/rnacenter/xrna/). Structure models of the IVSs revealed likely stem-loop conformations with predicted free energy values between 49.80 and $-58.90 \mathrm{kcal} / \mathrm{mol}$ for the various IVSs of the different organisms (Figure 4.1). The G+C content of the IVSs were found to be significantly lower than for the remainder of the 16S rRNA genes (Table 4.2). Intervening sequences have most commonly been observed in $23 \mathrm{~S}$ rRNA genes, although they have been observed in $16 \mathrm{~S}$ rRNA genes of several Archaea and Bacteria (Baker et al., 2003; Teyssier et al., 2003; Dewhirst et al., 2005; Villemur et al., 2007; Bautista-Zapanta et al., 2009; Tazumi et al., 2009; Tazumi et al., 2010). In some Archaea, IVSs function as small nucleolar 
RNAs (snoRNAs) and guide rRNA processing (Omer et al., 2000; Dieci et al., 2009). Others have suggested that IVSs in the H184 region may be involved in interactions with ribosomal proteins (Teyssier et al., 2003). However, the exact role of IVSs in Hippea species is unknown and beyond the scope of this study.

Neighbor-joining (Olsen correction, 500 bootstrap replicates) and maximumlikelihood (default parameters, 100 bootstrap replicates) analyses were conducted in ARB (Ludwig et al., 2004) and MEGA5 (Tamura et al., 2007), respectively. Results from these analyses placed the isolates within the genus Hippea (Figure 4.2). The 16S rRNA gene sequence similarity of all isolates to $H$. maritima $\mathrm{MH}_{2}{ }^{\mathrm{T}}$ was $\sim 95-98 \%$ when the IVSs were masked from the analysis and when only homologous nucleotide positions were compared (1364 bp) (Table 4.3). When the IVSs were included, sequence similarity was significantly lower and ranged from $\sim 81-93 \%$. Isolates from the same oceanic region (Atlantic, Eastern Pacific and Western Pacific) clustered together to form distinct biogeographical clades (Figure 4.2). Nested within each clade where sub-clades that formed based on the specific vent field of isolation. H. maritima $\mathrm{MH}_{2}{ }^{\mathrm{T}}$ falls within the Western Pacific Ocean clade and shares 97.9\% (93.3\% with H184 insert of $H$. maritima $\mathrm{MH}_{2}{ }^{\mathrm{T}}$ ) sequence similarity to its closest relative, strain Lau091128r. Similar biogeographic patterns have been seen for other thermophilic microorganisms from terrestrial environments using a variety of phylogenetic markers (Papke et al., 2003; Whitaker et al., 2003). 


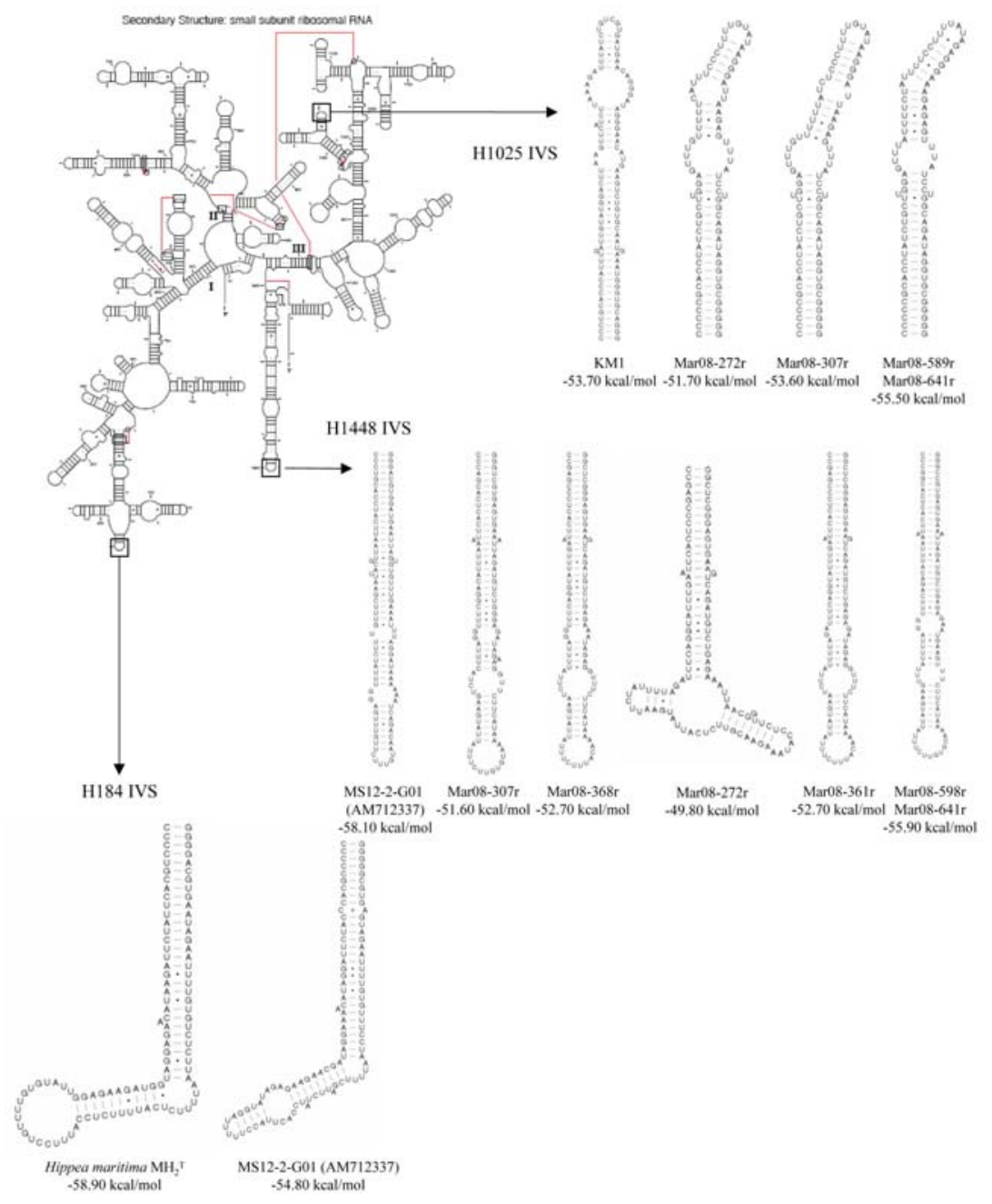

Figure 4.1. Predicted secondary structure of intervening sequences in the 16S rRNA of several of the new isolates and close relatives. The secondary structure of the 16S rRNA of E. coli is presented for reference to location and numbering of inserts. Structures were predicted in mfold and drawn with XRNA. Only the most energetically favorable conformations are presented. 
Table 4.2. Several of the new isolates and other Deltaproteobacteria have intervening sequences (IVSs) in their $16 \mathrm{~S}$ rRNA genes. The $\mathrm{G}+\mathrm{C}$ content of the IVSs were very different than that of the full gene.

\begin{tabular}{|c|c|c|c|c|c|}
\hline Strain name & $\begin{array}{c}\text { Total } \\
\text { sequence } \\
\text { length - bp } \\
(\% \mathrm{G}+\mathrm{C})\end{array}$ & $\begin{array}{l}\text { Sequence length } \\
\text { w/out IVSs }-\mathrm{bp} \\
(\% \mathrm{G}+\mathrm{C})\end{array}$ & $\begin{array}{c}\mathrm{H} 184^{\mathrm{a}}-\mathrm{bp} \\
(\% \mathrm{G}+\mathrm{C})\end{array}$ & $\begin{array}{c}\mathrm{H} 1025^{\mathrm{b}}-\mathrm{bp} \\
(\% \mathrm{G}+\mathrm{C})\end{array}$ & $\begin{array}{c}\mathrm{H} 1448^{\mathrm{c}}-\mathrm{bp} \\
\quad(\% \mathrm{G}+\mathrm{C})\end{array}$ \\
\hline Mar08-272r ${ }^{T}$ & $1670(56.53)$ & $1475(58.31)$ & - & 87 (47.13) & $108(39.81)$ \\
\hline Mar08-307r & $1680(56.31)$ & $1484(58.22)$ & - & 87 (47.13) & $109(37.61)$ \\
\hline Mar08-361r & $1603(56.89)$ & $1495(58.33)$ & - & - & $108(37.04)$ \\
\hline Mar08-368r & $1609(56.93)$ & $1501(58.36)$ & - & - & $108(37.04)$ \\
\hline Mar08-598r & $1635(56.39)$ & $1440(58.54)$ & - & $86(46.51)$ & $109(35.78)$ \\
\hline Mar08-641r & $1640(56.46)$ & $1445(58.62)$ & - & $86(46.51)$ & $109(35.78)$ \\
\hline$E P 5-r^{T}$ & $1509(58.71)$ & - & - & - & - \\
\hline EPR07-159r & $1511(58.70)$ & - & - & - & - \\
\hline Guay09-253r & $1501(58.76)$ & - & - & - & - \\
\hline Lau09-781r & $1508(60.01)$ & - & - & - & - \\
\hline Lau09-1128r & $1482(58.19)$ & - & - & - & - \\
\hline$K M 1^{T}$ & $1597(57.67)$ & $1490(58.72)$ & - & 107 (42.99) & - \\
\hline LR3-Dr & $1482(59.92)$ & - & - & - & - \\
\hline $\begin{array}{l}\text { H. maritima } \\
\mathrm{MH}_{2}{ }^{\mathrm{T}}\end{array}$ & $1607(56.81)$ & $1499(58.17)$ & $108(37.96)$ & - & - \\
\hline MS12-2-G01 & $1712(53.04)$ & $1498(55.14)$ & $107(42.06)$ & - & $107(34.58)$ \\
\hline
\end{tabular}

Organisms in italics were selected for metabolic and physiologic characterization.

${ }^{\text {a }} \mathrm{H} 184$ corresponds E. coli nucleotide 184 of the $16 \mathrm{~S}$ rRNA gene

${ }^{\mathrm{b}} \mathrm{H} 1025$ corresponds E. coli nucleotide 1025 of the $16 \mathrm{~S}$ rRNA gene

${ }^{c} \mathrm{H} 1448$ corresponds E. coli nucleotide 1448 of the $16 \mathrm{~S}$ rRNA gene

Four of the isolates representing three different geographic and geological settings (MAR (Mar08-272r ${ }^{\mathrm{T}}$ and Mar08-368r), EPR (EP5-r ${ }^{\mathrm{T}}$ ) and ELSC (KM1)) were selected for physiological and metabolic characterization (Table 4.1). All four isolates 
except Mar08-272 $r^{\mathrm{T}}$ and Mar08-368r shared less than 97\% 16S rRNA gene sequence similarity with one another when IVSs are masked from the analysis (Figure 4.2). The DNA G + C content of strains EP5-r ${ }^{\mathrm{T}}, \mathrm{KM} 1, \operatorname{Mar} 08-272 \mathrm{r}^{\mathrm{T}}$ and Mar08-368r were 37.1, 42.0, 35.6 and $37.9 \mathrm{~mol} \%$, respectively, as determined by thermal denaturation (Table 4.3) (Marmur and Doty, 1962). Unless stated otherwise, all characterization experiments were conducted in triplicate at $\mathrm{pH} 4.5-5.0$ and $65^{\circ} \mathrm{C}$ in sealed $25 \mathrm{ml}$ Balch tubes containing $5 \mathrm{ml}$ of media inoculated from fresh overnight cultures at $2.5-5 \%(\mathrm{v} / \mathrm{v})$. The influence of temperature on growth was determined by direct cell counts using a Petroff-Hauser counting chamber.

Strains Mar08-272r ${ }^{\mathrm{T}}$, Mar08-368r and KM1 all grew at temperatures between 40 and $72^{\circ} \mathrm{C}$ with growth optima between 60 and $65^{\circ} \mathrm{C}$ (Table 4.3). Strain EP5-r ${ }^{\mathrm{T}}$ had a slightly higher temperature range for growth of 45 to $75^{\circ} \mathrm{C}$ with optimal growth at $60^{\circ} \mathrm{C}$. Doubling times observed at optimal growth conditions ranged from $66-167 \mathrm{~min}$. The $\mathrm{pH}$ range for growth was the same for all isolates at 3.5 to 5.5 except for strain Mar08-272 $\mathrm{r}^{\mathrm{T}}$ which could only grow up to $\mathrm{pH}$ 5.0. No growth was observed at $\mathrm{pH} 3.0$ or 6.0. The optimal $\mathrm{pH}$ for growth for all strains was 4.5 to 5.0. $\mathrm{NaCl}$ was required for growth at 1-6\% (w/v) for Mar08-272r ${ }^{\mathrm{T}}$ and Mar08-368r, while KM1 and EP5-r ${ }^{\mathrm{T}}$ grew on $1-5 \%(\mathrm{w} / \mathrm{v}) \mathrm{NaCl}$. 


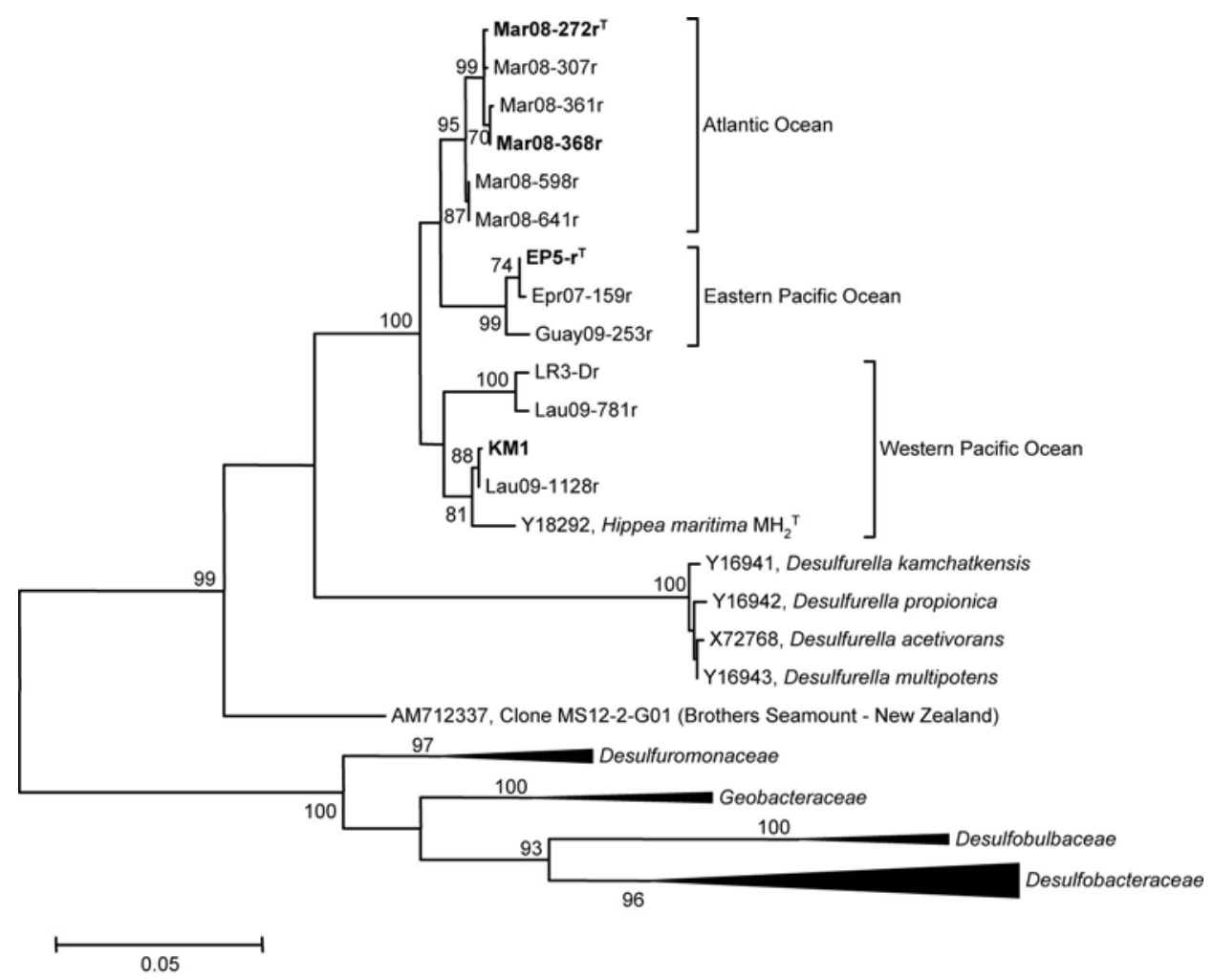

Figure 4.2. Maximum-likelihood tree based on 16S rRNA gene sequence comparisons of thirteen novel thermoacidophilic Desulfurellaceae and other families of the Deltaproteobacteria. The tree was generated considering only unambiguously aligned nucleotide position $(\mathrm{n}=1364)$. Isolates shown in bold were selected for characterization. Bootstrap values greater than or equal to 70 are shown at the base of nodes and were based on 100 replicates. The scale bar represents 0.05 changes per nucleotide position. Accession numbers of organisms used to generate phylogenetic tree that are not indicated in the tree are below: Desulfuromonas acetoxidans (AAEW02000008), Desulfuromonas thiophila (Y11560), Pelobacter carbinolicus (CP000142), Geobacter thiogenes (AF223382), Geobacter bremensis (U96917), Geobacter metallireducens (L07834), Desulfobulbus propionicus (AY548789), Desulfobulbus elongatus (X95180), Desulfobulbus japonicus (AB110549), Desulfosarcina variabilis (M34407), Desulfobacterium indolicum (AJ237607), Desulfobacterium vacuolatum (AF418178), Desulfobacterium autotrophicum (AF418177), Desulfobacula toluolica (AJ441316), Desulfobacula phenolica (AJ237606), Desulfobacter postgatei (AF418180), Desulfobacter curvatus (AF418175) and Desulfobacter vibrioformis (U12254). The tree was rooted with Aquifex pyrophilus (M83548) (not shown). Topology of the neighbor-joining tree was identical to that presented here (not shown). 
Table 4.3. Comparison of physiological traits of four new isolates with Hippea maritima $\mathrm{MH}_{2}{ }^{\mathrm{T}}$. Strains: 1, EP5-r ${ }^{\mathrm{T}}$; 2, KM1; 3, Mar08-272r ${ }^{\mathrm{T}}$; 4, Mar08-368r; 5, Hippea maritima $\mathrm{MH}_{2}{ }^{\mathrm{T}}$ (Miroshnichenko et al., 1999). +, positive; (+), weakly positive; -, negative; ND = not determined.

\begin{tabular}{|c|c|c|c|c|c|}
\hline Characteristic & 1 & 2 & 3 & 4 & 5 \\
\hline Origin of isolation & $\begin{array}{l}9^{\circ} \mathrm{N}, \text { East } \\
\text { Pacific } \\
\text { Rise }\end{array}$ & $\begin{array}{l}\text { Kilo Moana } \\
\text { vent field, } \\
\text { Eastern Lau } \\
\text { Spreading } \\
\text { Center }\end{array}$ & $\begin{array}{l}\text { Lucky Strike } \\
\text { vent field, } \\
\text { Mid-Atlantic } \\
\text { Ridge }\end{array}$ & $\begin{array}{l}\text { Lucky Strike } \\
\text { vent field } \\
\text { Mid-Atlantic } \\
\text { Ridge }\end{array}$ & $\begin{array}{c}\text { Matupi } \\
\text { Harbor, Papua } \\
\text { New Guinea }\end{array}$ \\
\hline $\begin{array}{l}\text { Cell size }(\mu \mathrm{m}) \\
\text { (length } \mathrm{x} \text { width) }\end{array}$ & $\begin{array}{l}0.7-1.5 \mathrm{x} \\
0.3-0.6\end{array}$ & $\begin{array}{c}2.0-3.0 \mathrm{x} \\
0.5-1.0\end{array}$ & $\begin{array}{c}2.0-3.5 \mathrm{x} \\
0.5-0.7\end{array}$ & $\begin{array}{l}2.0-3.0 x \\
0.5-1.05\end{array}$ & $\begin{array}{c}1.0-3.0 \mathrm{x} \\
0.4-0.8\end{array}$ \\
\hline $\begin{array}{l}\text { DNA G }+C \text { content } \\
(\mathrm{mol} \%)\end{array}$ & 37.1 & 41.1 & 35.6 & 37.3 & 40.4 \\
\hline $\begin{array}{l}16 \mathrm{~S} \text { rRNA gene } \\
\text { sequence similarity } \\
\text { to } H \text {. maritima } \\
\mathrm{MH}_{2}^{\mathrm{T}}(\%)\end{array}$ & 95.4 & 97.6 & 95.6 & 95.6 & N/A \\
\hline $\begin{array}{l}\text { Temperature range } \\
\left({ }^{\circ} \mathrm{C}\right) \text { (optimum) }\end{array}$ & $\begin{array}{c}45-75 \\
(60)\end{array}$ & $\begin{array}{c}40-72 \\
(60-65)\end{array}$ & $\begin{array}{c}40-72 \\
(60-65)\end{array}$ & $\begin{array}{c}40-72 \\
(60)\end{array}$ & $\begin{array}{l}40-65 \\
(52-54)\end{array}$ \\
\hline $\begin{array}{l}\text { Doubling time at } \\
\text { optimal temperature } \\
\text { and } \mathrm{pH}(\mathrm{min})\end{array}$ & 166 & 167 & 96 & 66 & ND \\
\hline $\begin{array}{l}\text { Average cell } \\
\text { density at } \\
\text { temperature and } \mathrm{pH} \\
\text { optima (cells } / \mathrm{ml} \text { ) }\end{array}$ & $8.88 \times 10^{7}$ & $7.03 \times 10^{7}$ & $7.90 \times 10^{7}$ & $8.06 \times 10^{7}$ & ND \\
\hline $\begin{array}{l}\mathrm{pH} \text { range } \\
\text { (optimum) }\end{array}$ & $\begin{array}{c}3.5-5.5 \\
(4.5-5.0)\end{array}$ & $\begin{array}{c}3.5-5.5 \\
(4.5-5.0)\end{array}$ & $\begin{array}{c}3.5-5.0 \\
(4.5-5.0)\end{array}$ & $\begin{array}{c}3.5-5.5 \\
(4.5-5.0)\end{array}$ & $\begin{array}{c}5.7-6.5 \\
(5.8-6.2)\end{array}$ \\
\hline $\mathrm{NaCl}$ range $(\% \mathrm{w} / \mathrm{v})$ & $1-5$ & $1-5$ & $1-6$ & $1-6$ & $2-3^{*}$ \\
\hline \multicolumn{6}{|l|}{ Substrates utilized: } \\
\hline Fumarate & + & - & + & + & $(+)$ \\
\hline Succinate & + & + & + & + & - \\
\hline Propionate & + & + & + & - & - \\
\hline Casamino acids & + & + & + & + & ND \\
\hline Ethanol & - & - & - & - & + \\
\hline Yeast extract & + & + & + & + & ND \\
\hline
\end{tabular}

*Range tested not reported.

Other electron donors utilized by all strains include acetate and hydrogen. All strains also require elemental sulfur as an electron acceptor. 
Isolates were tested for their ability to reduce a variety of inorganic electron acceptors with acetate $(15 \mathrm{mM})$ acting as the electron donor. Electron acceptors tested

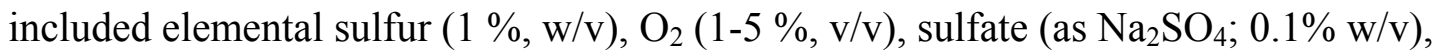
thiosulfate $(0.1 \%, \mathrm{w} / \mathrm{v})$, nitrate $\left(\right.$ as $\left.\mathrm{NaNO}_{3} ; 0.1 \%, \mathrm{w} / \mathrm{v}\right), \mathrm{Fe}^{3+}$ (as ferric citrate; $5 \mathrm{mM}$ ) and arsenate $\left(\right.$ as $\left.\mathrm{Na}_{2} \mathrm{HAsO}_{4} .7 \mathrm{H}_{2} \mathrm{O} ; 5 \mathrm{mM}\right)$. All characterized isolates were strictly anaerobic and only able to use elemental sulfur as an electron acceptor (Table 4.3).

Isolates were tested for their ability to utilize a variety of organic carbon sources with and without $\mathrm{CO}_{2}\left(\mathrm{~N}_{2}, 100 \%\right)$ in the headspace and sulfur acting as the sole electron acceptor. Vitamins were provided in all carbon substrate tests. Substrates were added at 0.1 and $0.02 \%(\mathrm{w} / \mathrm{v} ; \mathrm{v} / \mathrm{v}$ for liquids) and included yeast extract, Bacto peptone, Casamino acids, glucose, starch, acetate, butyrate, formate, fumarate, lactate, succinate, propionate, pyruvate, ethanol, methanol and benzoate. All strains could use acetate, succinate, yeast extract, and Casamino acids. Strains KM1, EP5-r ${ }^{\mathrm{T}}$ and Mar08-272r ${ }^{\mathrm{T}}$ could use propionate while EP5- $\mathrm{r}^{\mathrm{T}}$ and the two MAR strains (Mar08-272r ${ }^{\mathrm{T}}$ and Mar08368r) could also use fumarate (Table 4.3). No difference in growth was observed at the different concentrations of carbon substrates $(0.1$ and $0.02 \%)$. Isolates were not able to grow on yeast extract and Casamino acids without elemental sulfur indicating that they are not fermentative. Yeast extract was not required for growth if medium was supplemented with vitamins. All isolates were also capable of autotrophic growth with $\mathrm{H}_{2}, \mathrm{CO}_{2}$, sulfur and vitamins.

For morphological analysis by thin-section transmission electron microscopy (TEM), cells were prepared as previously described (Hunter and Beveridge, 2005). For 
negatively-stained whole mounts, $20 \mu \mathrm{L}$ drops of culture were allowed to adsorb onto the copper grids for 2 min and were subsequently post-stained in $2 \%$ uranyl acetate. Mar08-272 $\mathrm{r}^{\mathrm{T}}$ (Figure 4.3a), Mar08-368r (Figure 4.3b), and KM1 (Figure 4.3c) were rod shaped, while EP5-r ${ }^{T}$ was more ovoid in shape (Figure 4.3d). Cell dimensions of each isolate varied (Table 4.3). Strains were all Gram-negative and the peptidoglycan sacculi were often difficult to visualize (white arrow, Figure 4.3d). No intracellular membrane structures were observed, however strains Mar08-272r ${ }^{\mathrm{T}}$, Mar08-368r, and KM1 contained electron dense intracellular granules adjacent to the cytoplasmic membrane (black arrows, Figure 4.3). These inclusions closely resemble intracellular mixedvalence iron granules formed by Shewanella putrefaciens CN32 under anaerobic conditions (Glasauer et al., 2007). Consistent with this observation, when these strains were centrifuged for DNA extraction, small black precipitates were observed in cell pellets. Negative stains of each isolate revealed polar flagella extending from the surfaces of most cells (Figures 4.3e, f).

The physiological and phylogenetic characteristics of the newly described isolates are distinct from H. maritima $\mathrm{MH}_{2}{ }^{\mathrm{T}}$ and each other. Unlike H. maritima which was isolated from shallow $(<40 \mathrm{~m})$ marine thermal environments, our strains were all isolated from deep-sea vents $(>1500 \mathrm{~m})$. All new strains have very different $\mathrm{pH}$ and temperature ranges for growth from H. maritima $\mathrm{MH}_{2}{ }^{\mathrm{T}}$ which grows at $\mathrm{pH} 5.7$ to 6.5 and 40 to $65^{\circ} \mathrm{C}$ (Miroshnichenko et al., 1999). In contrast, the newly described isolates are obligately acidophilic growing at $\mathrm{pH} 3.5$ to 5.5 (Mar08-272 ${ }^{\mathrm{T}}$ only up to $\mathrm{pH} 5.0$ ) and temperatures between 40 and $72^{\circ} \mathrm{C}\left(\mathrm{EP} 5-\mathrm{r}^{\mathrm{T}}\right.$ grows between 45 and $\left.75^{\circ} \mathrm{C}\right)$. The new 
isolates also differ from H. maritima $\mathrm{MH}_{2}{ }^{\mathrm{T}}$ and each other, in their ability to utilize succinate and propionate $\left(\mathrm{EP} 5-\mathrm{r}^{\mathrm{T}}, \mathrm{KM} 1, \mathrm{Mar} 08-272 \mathrm{r}^{\mathrm{T}}\right)$, and in their inability to utilize ethanol (EP5-r ${ }^{\mathrm{T}}, \mathrm{KM} 1$, Mar08-272r ${ }^{\mathrm{T}}$ and Mar08-368r) and fumarate (KM1). Genomic $\mathrm{G}+\mathrm{C}$ content also varies amongst all isolates and H. maritima $\mathrm{MH}_{2}{ }^{\mathrm{T}}$ but are all within \pm $5 \%$. Additionally, based on their $16 \mathrm{~S}$ rRNA phylogenies, two of the isolates are distinct species ( $\sim 95 \%$ 16S rRNA gene sequence similarity) (Table 4.3$)$.

Based on the phenotypic (primarily acidophily, carbon substrate utilization and temperature range for growth) and phylogenetic differences between the new isolates and H. maritima $\mathrm{MH}_{2}{ }^{\mathrm{T}}$, we propose emending the description of the genus Hippea and designating two new species, namely, Hippea jasoniae sp. nov. strain Mar08-272r ${ }^{\mathrm{T}}$ and Hippea alviniae sp. nov. strain EP5- ${ }^{\mathrm{T}}$.

\section{Emended description of the genus Hippea}

Cells are Gram-negative rods or ovoid in shape. Moderate thermophiles. Neutrophiles to obligate acidophiles. Obligate anaerobes. Metabolize by reduction of elemental sulfur. Substrates utilized include: $\mathrm{H}_{2}$, volatile fatty acids, fatty acids and alcohols. Growth products are $\mathrm{CO}_{2}$ and $\mathrm{H}_{2} \mathrm{~S}$. The $\mathrm{G}+\mathrm{C}$ content of the type strain of the type species is $40 \mathrm{~mol} \%$. Inhabits shallow to deep submarine hydrothermal vents. The type species is Hippea maritima. 

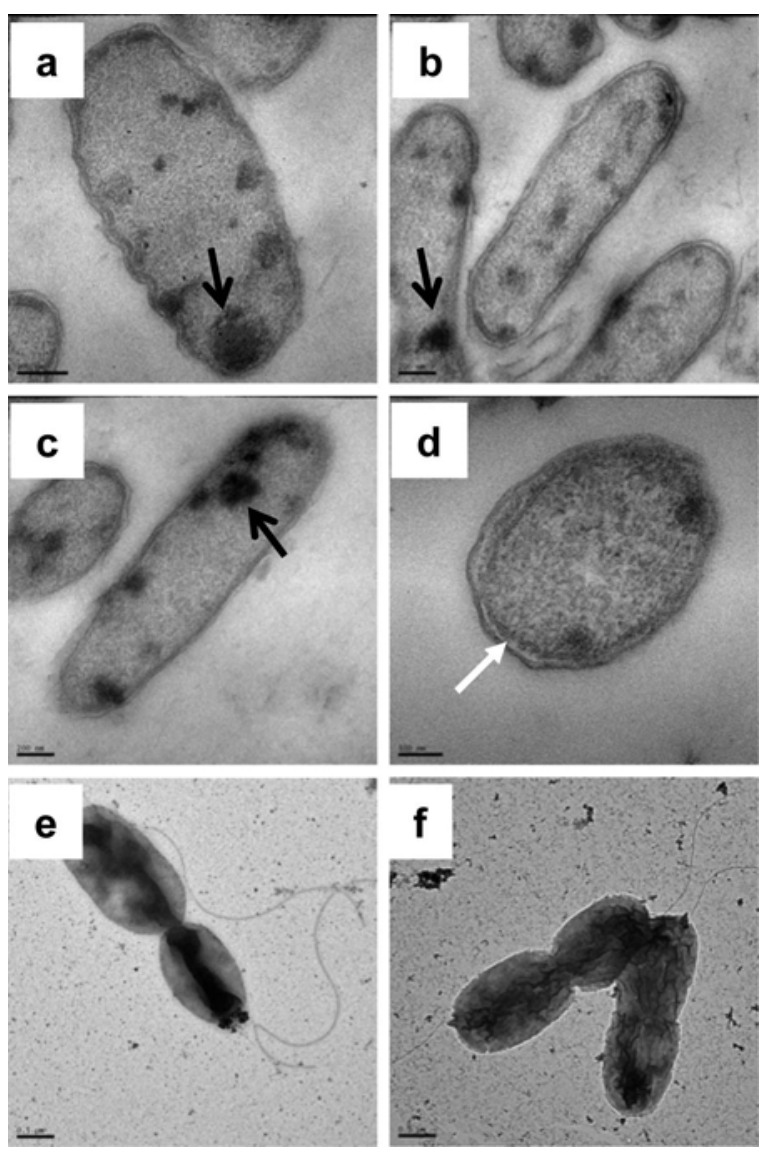

Figure 4.3. Thin section electron micrographs of strains Mar08-272rT (a), Mar08-368r (b), KM1T (c) and EP5rT (d). Negatively stained cells of strain Mar08-368r (e) and EP5rT (f) show flagella. Black arrows in $\mathbf{a}, \mathbf{b}$ and $\mathbf{c}$ point to areas where electron dense granules are evident. The white arrow in $\mathbf{d}$ shows where the peptidoglycan sacculus is visible. Scale bar in $\mathbf{a}, \mathbf{b}$ and $\mathbf{c}$ corresponds to $200 \mathrm{~nm}$, while $\mathbf{d}$ is $100 \mathrm{~nm}$. The scale bar in e and $\mathbf{f}$ is $500 \mathrm{~nm}$.

\section{Description of Hippea jasoniae sp. nov.}

Hippea jasoniae (ja.so.ni'a.e. N.L. fem. gen. n. jasoniae of Jason, named in honor of the ROV Jason II which collected the samples harboring this strain and has been essential in the exploration of deep-sea hydrothermal environments). 
Cells are motile, Gram-negative rods, 2.0-3.5 $\mu \mathrm{m}$ long and 0.5-0.7 $\mu \mathrm{m}$ wide. Moderate thermophiles $\left(40-72^{\circ} \mathrm{C}\right.$, optimal $\left.60-65^{\circ} \mathrm{C}\right)$. Obligate acidophiles $(\mathrm{pH} 3.5-5.0$, optimal $\mathrm{pH} 4.5-5.0)$. Obligate anaerobes. Requires $\mathrm{NaCl}(1-6 \% \mathrm{w} / \mathrm{v})$ for growth. Metabolize by reduction of elemental sulfur. Growth substrates are $\mathrm{H}_{2} / \mathrm{CO}_{2}$, acetate, fumarate, succinate, propionate (not all strains), Casamino acids and yeast extract. Yeast extract is not required for growth if vitamins are provided. The $\mathrm{G}+\mathrm{C}$ content of the genomic DNA of the type strain is $35.6 \mathrm{~mol} \%$.

The type strain, Mar08-272 $\mathrm{r}^{\mathrm{T}}\left(=\mathrm{DSM} 24585^{\mathrm{T}}\right)$ was isolated from the Lucky Strike $\left(37^{\circ} 17.5240^{\prime} \mathrm{N}, 32^{\circ} 16.5085^{\prime} \mathrm{W}, 1624 \mathrm{~m}\right.$ depth) hydrothermal vent field along the Mid-Atlantic Ridge in the Atlantic Ocean.

\section{Description of Hippea alviniae sp. nov.}

Hippea alviniae (al.vi.ni'a.e. N.L. fem. gen. n. alviniae of Alvin, named in honor of the HOV Alvin which collected the samples harboring this strain).

Cells are motile, Gram-negative ovoid rods, 0.7-1.5 $\mu \mathrm{m}$ long and of 0.3-0.6 $\mu \mathrm{m}$ wide. Moderate thermophiles $\left(45-75^{\circ} \mathrm{C}\right.$, optimal $\left.60^{\circ} \mathrm{C}\right)$. Obligate acidophiles (pH 3.55.5, optimal $\mathrm{pH} 4.5-5.0)$. Obligate anaerobes. Requires $\mathrm{NaCl}(1-5 \% \mathrm{w} / \mathrm{v})$ for growth. Metabolize by reduction of elemental sulfur. Growth substrates are $\mathrm{H}_{2} / \mathrm{CO}_{2}$, acetate, fumarate, succinate, propionate, Casamino acids and yeast extract. Yeast extract is not required for growth if vitamins are provided. The $\mathrm{G}+\mathrm{C}$ content of the genomic DNA of the type strain is $37.1 \mathrm{~mol} \%$. 
The type strain, EP5-r ${ }^{\mathrm{T}}\left(=\mathrm{DSM} 24586^{\mathrm{T}}\right)$, was isolated from " $\mathrm{A}$ ” vent $\left(9^{\circ}\right.$ $46.5003^{\prime} \mathrm{N}, 104^{\circ} 16.8100^{\prime} \mathrm{W}, 2520 \mathrm{~m}$ depth) along the East Pacific Rise in the eastern Pacific Ocean.

\section{Contributions}

For this project, I enriched and isolated organisms with Yitai Liu, performed characterization experiments, performed all molecular and phylogenetic analyses of isolates, generated secondary structure models, interpreted all data and wrote the manuscript for publication. Electron microscopy was performed by Ryan Hunter. 


\title{
Chapter 5: Biogeography of the Thermoacidophilic Deep-Sea Hydrothermal Vent Euryarchaeota 2 (DHVE2).
}

\begin{abstract}
The first cultivated thermoacidophile from deep-sea hydrothermal environments, Aciduliprofundum boonei $\mathrm{T} 469^{\mathrm{T}}$, belongs to the deep-sea hydrothermal vent euryarchaeota 2 (DHVE2) lineage that, based on 16S rRNA gene surveys, is widespread at deep-sea hydrothermal vents. However, relatively little is known about the overall distribution and phylogenetic diversity of this important lineage. In this study, we examined the distribution, relative abundance, co-occurrence patterns and cultivable diversity of thermoacidophilic DHVE2 in deposits from several geochemically distinct vent fields. Quantitative polymerase chain reaction (qPCR) assays with primers specific for the DHVE2 and most Archaea were employed to determine the occurrence and relative abundance of the DHVE2 in native vent deposits. Mining of pyrosequencing data was conducted to look for correlations in the distribution of the DHVE2 with other Archaea. Deposits from numerous vent sites were also used as inocula for enrichment cultures targeting the DHVE2. Results from this study demonstrate the ubiquity of the DHVE2 at the vent field scale and suggest that they are significant members of the archaeal communities of most mature vent deposits, especially horizontal flange structures. Furthermore, using local similarity analysis (LSA), the occurrence of the DHVE2 was positively correlated with other
\end{abstract}


Euryarchaeota and negatively correlated with mostly Crenarchaeota in pyrosequencing data from several vent fields. Targeted cultivation efforts resulted in the isolation of 15 new isolates from six different vent fields expanding the cultivable diversity of this lineage to vents along the East Pacific Rise and Mid-Atlantic Ridge. Overall, this study increases our understanding of the biogeography of the DHVE2 and identifies factors that may influence thermoacidophily in deep-sea hydrothermal environments.

\section{Introduction}

The diversity of Archaea associated with marine hydrothermal vent habitats is unrivaled in any other ecosystem on Earth (Auguet et al., 2009). Much of this diversity resides within the Euryarchaeota where numerous cultivated and uncultivated lineages appear to be endemic to the deep-sea. One such lineage is the deep-sea hydrothermal vent euryarchaeota 2 (DHVE2) (Takai and Horikoshi, 1999). Our knowledge of the distribution and diversity of the DHVE2 is based primarily on cultivation-independent studies (Table 5.1). These studies established that the DHVE2 are widespread and can account for up to $15 \%$ of the archaeal diversity, suggesting that they are important components of deep-sea hydrothermal ecosystems (Reysenbach et al., 2006). 
Table 5.1. Summary of $16 \mathrm{~S}$ rRNA gene sequences previously detected in marine hydrothermal environments. All listed sequences are greater than $600 \mathrm{bp}$ in length and share greater than $94 \%$ sequence similarity with Aciduliprofundum boonei T469 .

\begin{tabular}{|c|c|c|c|}
\hline $\begin{array}{l}\text { Accession } \\
\text { Number }\end{array}$ & Clone Name & Vent Field & Reference \\
\hline AB247823 & pLM14A-5 & $\begin{array}{l}\text { Mariner - Eastern Lau } \\
\text { Spreading Center }\end{array}$ & unpublished \\
\hline AB052986 & pPACMA-Q & Manus Basin & (Takai et al., 2001) \\
\hline AB052983 & pРACMA-M & Manus Basin & (Takai et al., 2001) \\
\hline AB052990 & pPACMA-W & Manus Basin & (Takai et al., 2001) \\
\hline AB052985 & pPACMA-P & Manus Basin & (Takai et al., 2001) \\
\hline AB366574 & SSM040-14 & $\begin{array}{l}\text { Suiyo Seamount, Izu- } \\
\text { Ogasawara Arc }\end{array}$ & (Kimura et al., 2010) \\
\hline AB019740 & pSSMCA108 & $\begin{array}{l}\text { Suiyo Seamount, Izu- } \\
\text { Ogasawara Arc }\end{array}$ & $\begin{array}{l}\text { (Takai and Horikoshi, } \\
\text { 1999) }\end{array}$ \\
\hline AB019739 & pMC2A10 & $\begin{array}{l}\text { Myojin Knoll, Izu- } \\
\text { Ogasawara Arc }\end{array}$ & $\begin{array}{l}\text { (Takai and Horikoshi, } \\
\text { 1999) }\end{array}$ \\
\hline AB019741 & pISA12 & $\begin{array}{l}\text { Iheya Basin, Middle } \\
\text { Okinawa Trough }\end{array}$ & $\begin{array}{c}\text { (Takai and Horikoshi, } \\
\text { 1999) }\end{array}$ \\
\hline AB019742 & pISA42 & $\begin{array}{l}\text { Iheya Basin, Middle } \\
\text { Okinawa Trough }\end{array}$ & $\begin{array}{l}\text { (Takai and Horikoshi, } \\
\text { 1999) }\end{array}$ \\
\hline AB175593 & IACC-11 & $\begin{array}{l}\text { Iheya Basin, Middle } \\
\text { Okinawa Trough }\end{array}$ & (Nakagawa et al., 2005d) \\
\hline AB197209 & IAP $6.5 \mathrm{~m}-12$ & $\begin{array}{l}\text { Iheya Basin, Middle } \\
\text { Okinawa Trough }\end{array}$ & unpublished \\
\hline AB302005 & P816_a_1.07 & $\begin{array}{l}\text { Yonaguni Knoll, Southern } \\
\text { Okinawa Trough }\end{array}$ & (Nunoura et al., 2010) \\
\hline AB235350 & pYK04-8A-26 & $\begin{array}{l}\text { Yonaguni Knoll, Southern } \\
\text { Okinawa Trough }\end{array}$ & (Nunoura et al., 2010) \\
\hline AB611429 & HTM1039Pn-A31 & $\begin{array}{c}\text { Hatoma Knoll - Okinawa } \\
\text { Trough }\end{array}$ & unpublished \\
\hline AB611418 & HTM1039Pn-A12 & $\begin{array}{c}\text { Hatoma Knoll - Okinawa } \\
\text { Trough }\end{array}$ & unpublished \\
\hline AB611448 & HTM1036Pn-A103 & $\begin{array}{c}\text { Hatoma Knoll - Okinawa } \\
\text { Trough }\end{array}$ & unpublished \\
\hline AB611404 & HTM871W-A1 & $\begin{array}{c}\text { Hatoma Knoll - Okinawa } \\
\text { Trough }\end{array}$ & unpublished \\
\hline AB611358 & HTM873S-A1 & $\begin{array}{c}\text { Hatoma Knoll - Okinawa } \\
\text { Trough }\end{array}$ & unpublished \\
\hline AB611414 & HTM1039Pn-A8 & $\begin{array}{c}\text { Hatoma Knoll - Okinawa } \\
\text { Trough }\end{array}$ & unpublished \\
\hline AB611339 & HTM866S-A3 & $\begin{array}{c}\text { Hatoma Knoll - Okinawa } \\
\text { Trough }\end{array}$ & unpublished \\
\hline AB611424 & HTM1039Pn-A24 & $\begin{array}{c}\text { Hatoma Knoll - Okinawa } \\
\text { Trough }\end{array}$ & unpublished \\
\hline AB611425 & HTM1039Pn-A26 & $\begin{array}{c}\text { Hatoma Knoll - Okinawa } \\
\text { Trough }\end{array}$ & unpublished \\
\hline AB611367 & HTM873I-A23 & $\begin{array}{c}\text { Hatoma Knoll - Okinawa } \\
\text { Trough }\end{array}$ & unpublished \\
\hline AB611430 & HTM1039Pn-A32 & $\begin{array}{c}\text { Hatoma Knoll - Okinawa } \\
\text { Trough }\end{array}$ & unpublished \\
\hline AB611375 & HTM1039S-A21 & Hatoma Knoll - Okinawa & unpublished \\
\hline
\end{tabular}




\begin{tabular}{|c|c|c|c|}
\hline AB611386 & HTM1036S-A21 & $\begin{array}{c}\text { Hatoma Knoll - Okinawa } \\
\text { Trough }\end{array}$ & unpublished \\
\hline EU107487 & A10 & $\begin{array}{c}\text { Snail surface - Okinawa } \\
\text { Trough }\end{array}$ & unpublished \\
\hline $\mathrm{AB} 167485$ & TOTO-A6-1 & Toto Cladera - Mariana Arc & (Nakagawa et al., 2006) \\
\hline AB167482 & TOTO-A1-28 & Toto Cladera - Mariana Arc & (Nakagawa et al., 2006) \\
\hline $\mathrm{AB} 167498$ & TOTO-ISCS-A45 & Toto Cladera - Mariana Arc & (Nakagawa et al., 2006) \\
\hline AB167486 & TOTO-A6-12 & Toto Cladera - Mariana Arc & (Nakagawa et al., 2006) \\
\hline AB293232 & Pcsc1A26 & Southern Mariana Trough & (Kato et al., 2010) \\
\hline AB293231 & $P \csc 1 \mathrm{~A} 25$ & Southern Mariana Trough & (Kato et al., 2010) \\
\hline AB293234 & Pcsc1A38 & Southern Mariana Trough & (Kato et al., 2010) \\
\hline EU574651 & CPA_17 & Northern Mariana Backarc & unpublished \\
\hline AM749972 & 854e_arc05A & $\begin{array}{c}\text { Kermadec Arc }- \text { New } \\
\text { Zealand }\end{array}$ & (Stott et al., 2008) \\
\hline AB177273 & ODP1251A15.24 & Cascadia Margin Sediments & (Inagaki et al., 2006) \\
\hline AF355838 & 33-P120A99 & Juan de Fuca Ridge & (Huber et al., 2002b) \\
\hline DQ118404 & Fosmid Alv-FOS4 & $13^{\circ} \mathrm{N}$ East Pacific Rise & (Moussard et al., 2006b) \\
\hline DQ082975 & FOS2 & $13^{\circ} \mathrm{N}$ East Pacific Rise & (Moussard et al., 2006a) \\
\hline DQ082976 & FOS3 & $13^{\circ} \mathrm{N}$ East Pacific Rise & (Moussard et al., 2006a) \\
\hline DQ082980 & metF2 & $13^{\circ} \mathrm{N}$ East Pacific Rise & (Moussard et al., 2006a) \\
\hline DQ082964 & met50 & $13^{\circ} \mathrm{N}$ East Pacific Rise & (Moussard et al., 2006a) \\
\hline DQ082953 & met21 & $13^{\circ} \mathrm{N}$ East Pacific Rise & (Moussard et al., 2006a) \\
\hline DQ082954 & met24 & $13^{\circ} \mathrm{N}$ East Pacific Rise & (Moussard et al., 2006a) \\
\hline DQ082969 & metF8 & $13^{\circ} \mathrm{N}$ East Pacific Rise & (Moussard et al., 2006a) \\
\hline DQ082955 & met43 & $13^{\circ} \mathrm{N}$ East Pacific Rise & (Moussard et al., 2006a) \\
\hline DQ118403 & Fosmid Alv-FOS1 & $13^{\circ} \mathrm{N}$ East Pacific Rise & (Moussard et al., 2006b) \\
\hline AF526965 & pEPR193 & $13^{\circ} \mathrm{N}$ East Pacific Rise & (Nercessian et al., 2003) \\
\hline AF526964 & pEPR159 & $13^{\circ} \mathrm{N}$ East Pacific Rise & (Nercessian et al., 2003) \\
\hline AF526963 & pEPR122 & $13^{\circ} \mathrm{N}$ East Pacific Rise & (Nercessian et al., 2003) \\
\hline AF526962 & pEPR719 & $13^{\circ} \mathrm{N}$ East Pacific Rise & (Nercessian et al., 2003) \\
\hline AF526961 & pEPR707 & $13^{\circ} \mathrm{N}$ East Pacific Rise & (Nercessian et al., 2003) \\
\hline AY672495 & $\mathrm{CH} 8$ 7a Arc & $9^{\circ} \mathrm{N}$ East Pacific Rise & (Kormas et al., 2006) \\
\hline AF356635 & $\mathrm{G} 26-\mathrm{C} 5 \overline{6}$ & Guaymas Basin & unpublished \\
\hline AF356637 & G26_C73 & Guaymas Basin & unpublished \\
\hline AF068820 & VC2.1 Arc13 & $\begin{array}{c}\text { Snake Pit - Mid-Atlantic } \\
\text { Ridge }\end{array}$ & (Reysenbach et al., 2000) \\
\hline AB496479 & pMARA06_14 & $\begin{array}{c}\text { Lucky Strike - Mid-Atlantic } \\
\text { Ridge }\end{array}$ & unpublished \\
\hline FM863771 & $\mathrm{T} 48 \mathrm{R}$ & $\begin{array}{l}\text { TAG - Mid-Atlantic Ridge } \\
\text { (Rimacaris gut) }\end{array}$ & unpublished \\
\hline FM863772 & T14R & $\begin{array}{l}\text { TAG - Mid-Atlantic Ridge } \\
\text { (Rimacaris gut) }\end{array}$ & unpublished \\
\hline FM863773 & $\mathrm{T} 22 \mathrm{R}$ & $\begin{array}{l}\text { TAG - Mid-Atlantic Ridge } \\
\text { (Rimacaris gut) }\end{array}$ & unpublished \\
\hline AY251065 & FT17A09 & Central Indian Ridge & (Hoek et al., 2003) \\
\hline AY251064 & FT17A03 & Central Indian Ridge & (Hoek et al., 2003) \\
\hline
\end{tabular}


The first representative of the DHVE2 was obtained in pure culture and represents the first obligate thermoacidophile discovered from deep-sea vents despite the known acidity of most hydrothermal fluids ( $\mathrm{pH} 2.8-4.5)$ and predictions of acidic microhabitats within the walls of vent deposits (Tivey, 2004; Reysenbach et al., 2006). The organism, Aciduliprofundum boonei $\mathrm{T} 469^{\mathrm{T}}$, was isolated from the Mariner vent field along the Eastern Lau Spreading Center (ELSC) in the western Pacific Ocean and grows between 55 and $75^{\circ} \mathrm{C}$ and $\mathrm{pH} 3.3$ to 5.8. The genome of the isolate revealed a specialized metabolism based on peptide fermentation and auxotrophy for several amino acids (Reysenbach and Flores, 2008).

Acidic habitats are generated in vent deposits by conductive cooling of endmember fluids or by transport of hydrothermal fluids outward across deposit walls by diffusion only (Tivey, 2004). However, when hydrothermal fluids and seawater mix, either in the subsurface or by advection across deposit walls, neutrality of the fluids is quickly reached resulting in most marine hydrothermal vent habitats being circumneutral. Therefore, the $\mathrm{pH}$ of end-member fluids and the degree of fluid mixing within an individual deposit are likely important factors in controlling the distribution and abundance of thermoacidophilic DHVE2 both within and between vent fields. Factors that influence the $\mathrm{pH}$ of hydrothermal fluids are related to the geologic setting and include the presence of organic sediments, which increases the $\mathrm{pH}$ of fluids like what occurs in the Guaymas Basin, and inputs of magmatic volatiles like what is observed in the low $\mathrm{pH}$ fluid of Mariner (Tivey, 2007). Fluid mixing styles can be influenced by the type of vent structure as hydrothermal fluids associated with 
horizontal flanges are conductively cooled with little or no mixing of seawater, while the mixing styles of vertical chimney structures are much more variable (Tivey, 2004). Assuming other DHVE2 possess similar physiological and metabolic features as $A$. boonei $\mathrm{T} 469^{\mathrm{T}}$, then understanding more about the biogeography of this archaeal lineage can begin to identify possible constraints on thermoacidophily in deep-sea hydrothermal ecosystems. Therefore, we investigated the occurrence, abundance and diversity of the DHVE2 in hydrothermal vent deposits from several geochemically distinct vent fields using a combination of cultivation-dependent and -independent approaches. Here we expand the geographic distribution and phylogeny of thermoacidophilic DHVE2, and provide clues to factors that may influence their distribution and abundance.

\section{Materials and Methods}

Sample collection

Deep-sea hydrothermal mineral deposits were collected with the HOV Alvin or ROV Jason II during research cruises to the East Pacific Rise (EPR) in 2007, the MidAtlantic Ridge (MAR) in 2008, the Eastern Lau Spreading Center (ELSC) in 2009 and the Guaymas Basin (GB) in 2009. Once shipboard, individual samples were processed and stored anaerobically as previously described (Götz et al., 2002; Reysenbach et al., 2006; Flores et al., 2011). 
Quantitative polymerase chain reaction ( $q P C R$ )

Nucleic acids from environmental samples were extracted from homogenized samples $(\approx 1.6-3.2$ grams) using the Ultra Clean Soil DNA Isolation Kit (MoBio Laboratories) according to the modified protocol of Reysenbach et al. (2006).

Quantitative PCR was performed according to manufacturer's instructions using the Quantitect SYBR green PCR kit (Qiagen, Inc., Valencia, CA) and $0.8 \mu \mathrm{M}$ final primer concentration, with melting curves performed at the end of each reaction to ensure product specificity. Primers and thermocycling conditions were followed according to Reysenbach et al. (2006). Gene copy numbers presented were normalized by the amount of material in grams (wet weight) extracted.

\section{Local similarity analysis}

Pyrosequencing data of the variable region 4 (V4) of archaeal 16S rRNA genes from 57 deposits from the MAR, ELSC and Guyamas Basin were trimmed, aligned and clustered at $97 \%$ sequence similarity as previously described (Flores et al., 2011). DHVE2 operational taxonomic units (OTUs) were identified by first BLASTing (Altschul et al., 1990) a representative sequences of each OTU against the 16S rRNA gene of A. boonei $\mathrm{T}_{46} 9^{\mathrm{T}}$, selecting OTUs with greater than $95 \%$ sequence similarity to A. boonei $\mathrm{T} 469^{\mathrm{T}}$, manually aligning sequences and generating phylogenetic trees in a custom ARB database (Ludwig et al., 2004). For local similarity analysis (LSA), all OTUs with greater than 100 sequences, including three DHVE2 OTUs, were normalized to percent and imported into the LSA compute tool 
(http://meta.cmb.usc.edu/) using default parameters. LSA explores co-varying relationships of microbial species (or OTUs) to one another and to environmental parameters (Ruan et al., 2006). In this case, we used LSA to look at the relationships between co-varying OTUs as no complementary environmental data was available. Results of LSA were pruned to include only the two most prevalent DHVE2 OTUs (ID\#'s 727 and 1148), and other OTUs that were positively and negatively correlated (P $<0.05)$. Visualization of the resulting interaction network was performed using Cytoscape (Shannon et al., 2003). Correlated OTUs were classified to the lowest taxonomic level that had a bootstrap value of $\geq 50 \%$ (Claesson et al., 2009) using the RDP-classifier (Wang et al., 2007).

\section{Enrichment culturing and phylogenetic analysis}

Medium used for enrichments was identical to that used by Reysenbach et al. (2006). The $\mathrm{pH}$ was adjusted to 4.5 with sulfuric acid prior to autoclaving at $105^{\circ} \mathrm{C}$ for

1 hour to avoid melting the sulfur. Cysteine or sulfide $\left(0.5 \mathrm{~g} \mathrm{l}^{-1}\right)$ was added as a reducing agent from sterile stock solutions after autoclaving. For initial enrichments, 5 $\mathrm{ml}$ of medium was inoculated with $0.5 \mathrm{ml}$ of sulfide-deposit slurry and incubated at $70^{\circ} \mathrm{C}$.

Genomic DNA was extracted from isolated cultures using the DNeasy Tissue Kit (Qiagen) following the manufacturer's protocol. The 16S rRNA gene of each isolate was amplified, purified and sequenced as described previously (Reysenbach et al., 2006). Nearly complete 16S rRNA gene sequences (FR865176-FR865190) were 
assembled using the software SeqMan, compared to the NCBI non-redundant database using BLAST (Altschul et al., 1990) and aligned in ARB (Ludwig et al., 2004) according to secondary structure constraints. Neighbor-joining (Olsen correction, 500 bootstrap replicates) and maximum-likelihood (default parameters, 100 bootstrap replicates) analyses were conducted in ARB (Ludwig et al., 2004) and MEGA5 (Tamura et al., 2007), respectively, on only unambiguous nucleotide positions (789 nt).

\section{Results and Discussion}

\section{Occurrence and relative abundance of the DHVE2}

To determine the occurrence and relative abundance of the DHVE2 in deposits from geologically distinct vent fields, 16S rRNA genes were quantified for most Archaea and the DHVE2 using qPCR. Archaeal 16S rRNA genes were successfully amplified from 130 samples with deposits from Tui Malila along the ELSC having, on average, the lowest copy number $\left(8.35 \times 10^{4}\right.$ copies $)$ and TAG along the MAR having the highest copy number $\left(9.78 \times 10^{7}\right.$ copies $)$ (Table 5.2). Although these values cover a wide range, they are similar to archaeal abundances that have been reported from other hydrothermal vent deposits (e.g., Takai et al., 2001; Schrenk et al., 2003; Nakagawa et al., 2005d; Zhou et al., 2009). Using group specific primers, the DHVE2 were observed at all vent fields but in only 60\% (78/130) of samples analyzed. At individual vent fields, the DHVE2 were most frequently observed at Mariner ( $80 \%$ of samples), EPR (77.8\%) and TAG (75\%). In contrast, they were detected in less than $50 \%$ of 
samples from Tui Malila (37.5\%), Tow Cam (42.9\%) and the Guaymas Basin (48.1\%). While their occurrence varied within an individual vent field, these results clearly illustrate the ubiquity of the DHVE2 and suggest that differences in the geological properties that influence end-member fluid $\mathrm{pH}$ over the ranges we examined do not inhibit colonization by the DHVE2 at these vent sites. Assuming all members of the DHVE2 are thermoacidophilic, then thermoacidophily is a common ecological niche in deep-sea hydrothermal ecosystems.

In samples where the DHVE2 were not detected, the average archaeal abundance was significantly lower at $3.64 \times 10^{5}$ copies/gram than in deposits where the DHVE2 were observed, which averaged $3.34 \times 10^{7}$ copies/gram $(\mathrm{P}=0.002$, one-tailed T-test) (Tables 5.3-5.6). Also, deposits where the DHVE2 were absent were typically younger, thin-walled structures without an obvious biofilm on the exterior of the deposit. Previous work had demonstrated that, while Archaea are typically the initial colonizers of newly formed vent deposits, they are primarily autotrophic with later colonization by heterotrophs (Page et al., 2008). Consequently, the occurrence of the DHVE2 in an individual deposit may be dependent upon the presence of a mature microbial community from which to scavenge fermentable peptides (Reysenbach and Flores, 2008). Older deposits also generally have more defined walls and fluid conduits that would help isolate the hydrothermal fluids from seawater allowing for more conductive cooling of the fluids. 
Table 5.2. Results of qPCR assays to determine the occurrence and relative abundance of the DHVE2 in hydrothermal vent deposits from several different vent fields.

\begin{tabular}{|c|c|c|c|}
\hline & $\begin{array}{c}\text { Average archaeal 16S } \\
\text { rRNA gene copies per } \\
\text { gram of deposit } \\
\text { (s.e.m.) }\end{array}$ & $\begin{array}{c}\text { Average DHVE2 16S } \\
\text { rRNA gene copies per } \\
\text { gram of deposit } \\
\text { (s.e.m.) }\end{array}$ & $\begin{array}{l}\text { Average proportion } \\
\text { of DHVE2 16S rRNA } \\
\text { gene copies }(\%)^{\dagger}\end{array}$ \\
\hline \multicolumn{4}{|c|}{ Eastern Lau Spreading Center } \\
\hline $\begin{array}{l}\text { Kilo Moana } \\
(\mathrm{n}=8,62.5 \%)^{*}\end{array}$ & $\begin{array}{c}2.86 \times 10^{7} \\
\left(1.25 \times 10^{7}\right)\end{array}$ & $\begin{array}{l}1.74 \times 10^{5} \\
\left(1.50 \times 10^{5}\right)\end{array}$ & 0.38 \\
\hline $\begin{array}{l}\text { Tow Cam } \\
(\mathrm{n}=7,42.9 \%)\end{array}$ & $\begin{array}{c}1.91 \times 10^{7} \\
\left(1.08 \times 10^{7}\right)\end{array}$ & $\begin{array}{c}5.39 \times 10^{5} \\
\left(3.32 \times 10^{5}\right)\end{array}$ & 1.21 \\
\hline $\begin{array}{l}\text { Tahi Moana } \\
(\mathrm{n}=11,63.6 \%)\end{array}$ & $\begin{array}{c}1.51 \times 10^{7} \\
\left(7.58 \times 10^{6}\right)\end{array}$ & $\begin{array}{c}5.65 \times 10^{5} \\
\left(2.02 \times 10^{5}\right)\end{array}$ & 2.39 \\
\hline $\begin{array}{l}\mathrm{ABE} \\
(\mathrm{n}=11,63.6 \%)\end{array}$ & $\begin{array}{l}7.25 \times 10^{6} \\
\left(2.78 \times 10^{6}\right)\end{array}$ & $\begin{array}{c}1.58 \times 10^{5} \\
\left(6.17 \times 10^{4}\right)\end{array}$ & 1.39 \\
\hline $\begin{array}{l}\text { Tui Malila } \\
(\mathrm{n}=16,37.5 \%)\end{array}$ & $\begin{array}{c}8.35 \times 10^{4} \\
\left(2.59 \times 10^{4}\right)\end{array}$ & $\begin{array}{c}2.30 \times 10^{4} \\
\left(9.22 \times 10^{3}\right)\end{array}$ & 12.88 \\
\hline $\begin{array}{l}\text { Mariner } \\
(\mathrm{n}=15,80.0 \%)\end{array}$ & $\begin{array}{c}3.14 \times 10^{6} \\
\left(2.11 \times 10^{6}\right)\end{array}$ & $\begin{array}{c}1.62 \times 10^{5} \\
\left(7.53 \times 10^{4}\right)\end{array}$ & 12.69 \\
\hline \multicolumn{4}{|l|}{ Mid-Atlantic Ridge } \\
\hline $\begin{array}{l}\text { Lucky Strike } \\
(\mathrm{n}=10,70 \%)\end{array}$ & $\begin{array}{c}6.41 \times 10^{5} \\
\left(4.22 \times 10^{5}\right)\end{array}$ & $\begin{array}{c}1.34 \times 10^{5} \\
\left(5.96 \times 10^{4}\right)\end{array}$ & 14.74 \\
\hline $\begin{array}{l}\text { Rainbow } \\
(\mathrm{n}=12,66.7 \%)\end{array}$ & $\begin{array}{c}2.15 \times 10^{7} \\
\left(7.68 \times 10^{6}\right)\end{array}$ & $\begin{array}{c}4.49 \times 10^{4} \\
\left(1.27 \times 10^{4}\right)\end{array}$ & 0.14 \\
\hline $\begin{array}{l}\text { TAG } \\
(\mathrm{n}=4,75.0 \%)\end{array}$ & $\begin{array}{c}9.78 \times 10^{7} \\
\left(5.98 \times 10^{7}\right)\end{array}$ & $\begin{array}{c}5.19 \times 10^{5} \\
\left(5.04 \times 10^{5}\right)\end{array}$ & 0.57 \\
\hline $\begin{array}{l}\text { Guaymas Basin } \\
(\mathrm{n}=27,48.1 \%)\end{array}$ & $\begin{array}{c}5.36 \times 10^{7} \\
\left(2.37 \times 10^{7}\right)\end{array}$ & $\begin{array}{c}1.52 \times 10^{6} \\
\left(5.03 \times 10^{5}\right)\end{array}$ & 1.36 \\
\hline $\begin{array}{l}\text { East Pacific Rise } \\
(\mathrm{n}=9,77.8 \%)\end{array}$ & $\begin{array}{c}4.08 \times 10^{5} \\
\left(1.62 \times 10^{5}\right)\end{array}$ & $\begin{array}{c}2.71 \times 10^{4} \\
\left(1.96 \times 10^{4}\right)\end{array}$ & 7.26 \\
\hline
\end{tabular}

${ }^{*}$ s.e.m. $=$ standard error of the mean

${ }^{\dagger}$ Average proportion of DHVE2 was calculated for only samples with positive amplification for both Archaea and the DHVE2.

${ }^{*}$ Numbers in parentheses indicate the total number of samples with positive archaeal amplification and the percentage of those with positive amplification of the DHVE2.

Quantitative PCR was also used to determine the proportion of the DHVE2 in the archaeal communities. Within individual vent fields, the proportion of DHVE2 16S rRNA gene copies ranged from $0.14 \%$ at Rainbow to $14.74 \%$ at Lucky Strike. Deposits 
from Mariner (12.69\%), Tui Malila (12.88\%) and EPR (7.26\%) also had, on average, a high proportion of DHVE2 sequences within their archaeal communities (Table 5.2). This level of relative abundance implies that, when the DHVE2 are present, they can be a significant component of the archaeal community. However, it is difficult to compare their relative abundance to other archaeal groups from previous studies because of differences in the methods employed to determine abundances (e.g., FISH, MPN culturing).
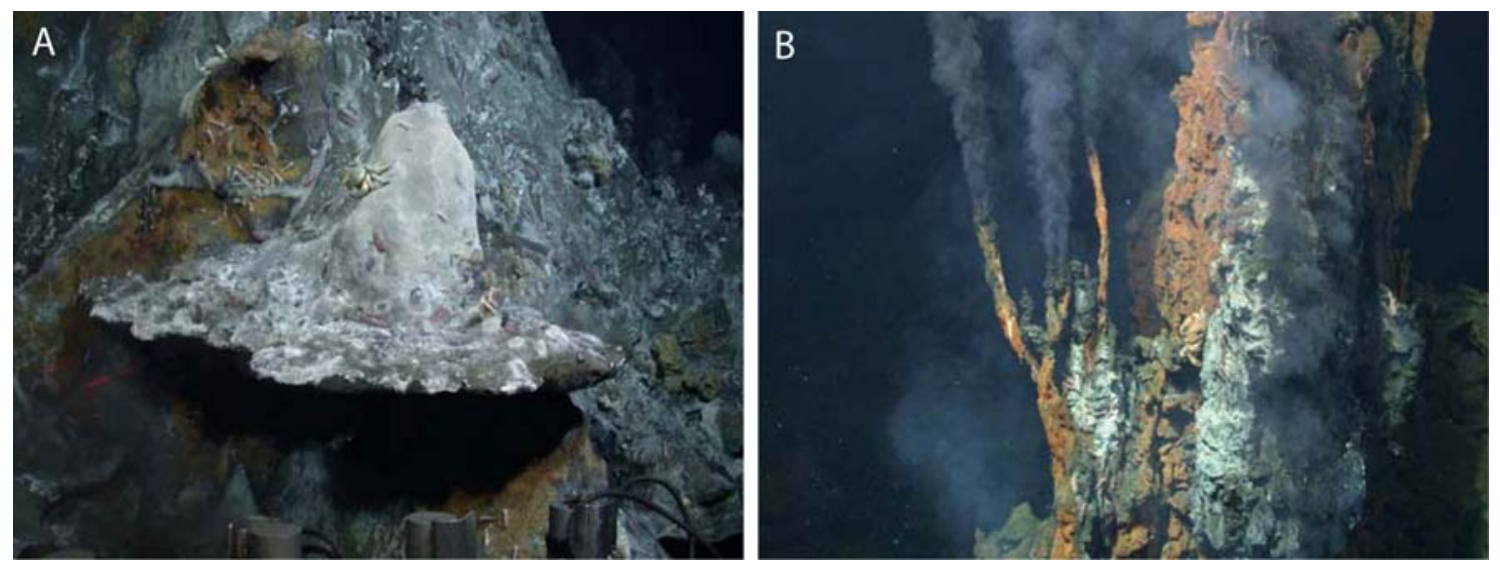

Figure 5.1. Photographs of a horizontal flange deposit (A) and vertical chimneys (B) from the Eastern Lau Spreading Center.

Individual samples having the highest proportion of DHVE2 gene copies were typically flanges (Tables 5.3-5.6). Flanges are horizontal, shelf-like structures that form in some hydrothermal systems (Figure 5.1) (Tivey, 2007). Hydrothermal fluids associated with flanges are conductively cooled by seawater with very little mixing of the fluids (Tivey, 2004). As a result, these fluids remain acidic as they cool to hospitable temperatures $\left(<120^{\circ} \mathrm{C}\right)$ and percolate vertically through the structure generating relatively larger thermoacidic zones than what is present in vertical chimney 
structures. In a recent study, the microbial community of a flange deposit from the Yonaguni Knoll IV hydrothermal field in the western Pacific Ocean was characterized using 16S rRNA gene cloning (Nunoura and Takai, 2009). Results showed that the DHVE2 accounted for nearly $46 \%(16 / 35)$ of the archaeal clones in one subsample further supporting the observation that flanges can be "hot-spots" for the DHVE2 and likely, other thermoacidophiles.

Table 5.3. Results of qPCR assays to determine the occurrence and relative abundance of the DHVE2 in hydrothermal vent deposits from the East Pacific Rise (EPR). Values are the average of two replicates unless otherwise noted. Lower case letters next to sample names indicate paired samples.

\begin{tabular}{|c|c|c|c|c|}
\hline & $\begin{array}{c}\text { Archaeal } 16 \mathrm{~S} \text { rRNA } \\
\text { gene copies per gram of } \\
\text { deposit (s.e.m.). }\end{array}$ & $\begin{array}{l}\text { DHVE2 16S rRNA } \\
\text { gene copies per gram } \\
\text { of deposit (s.e.m.) }\end{array}$ & $\begin{array}{l}\text { Proportion of } \\
\text { DHVE2 16S } \\
\text { rRNA gene } \\
\text { copies }(\%)\end{array}$ & $\begin{array}{l}\text { Deposit type - } \\
\text { sample } \\
\text { location }\end{array}$ \\
\hline EPR07-15 & $\begin{array}{c}7.18 \times 10^{5} \\
\left(7.32 \times 10^{4}\right)\end{array}$ & $\begin{array}{c}1.44 \times 10^{5} \\
\left(3.39 \times 10^{2}\right)\end{array}$ & 20.01 & $\begin{array}{c}\text { Chimney - } \\
\text { outer }\end{array}$ \\
\hline EPR07-20 & $\begin{array}{c}1.47 \times 10^{5} \\
\left(1.12 \times 10^{4}\right)\end{array}$ & $\begin{array}{c}3.64 \times 10^{3} \\
\left(4.86 \times 10^{2}\right)\end{array}$ & 2.49 & $\begin{array}{l}\text { Chimney - } \\
\text { outer }\end{array}$ \\
\hline EPR07-45 & $\begin{array}{c}3.64 \times 10^{4} \\
\left(1.75 \times 10^{3}\right)\end{array}$ & $\mathrm{BDL}^{\S}$ & - & $\begin{array}{c}\text { Chimney - } \\
\text { outer }\end{array}$ \\
\hline EPR07-64 & $\begin{array}{l}6.10 \times 10^{4} \\
\left(6.87 \times 10^{3}\right)\end{array}$ & $\begin{array}{c}2.66 \times 10^{3} \\
\left(4.12 \times 10^{2}\right)\end{array}$ & 4.37 & $\begin{array}{l}\text { Chimney - } \\
\text { inner }\end{array}$ \\
\hline EPR07-70a & $\begin{array}{c}2.63 \times 10^{5} \\
\left(3.55 \times 10^{4}\right)\end{array}$ & $\begin{array}{l}1.23 \times 10^{4} \\
\left(2.34 \times 10^{3}\right)\end{array}$ & 4.68 & $\begin{array}{c}\text { Chimney - } \\
\text { outer }\end{array}$ \\
\hline EPR07-75a & $\begin{array}{c}8.12 \times 10^{3} \\
\left(1.14 \times 10^{2}\right)\end{array}$ & $\begin{array}{c}3.36 \times 10^{3} \\
\left(4.41 \times 10^{2}\right)\end{array}$ & 41.34 & $\begin{array}{c}\text { Chimney - } \\
\text { inner }\end{array}$ \\
\hline EPR07-138 & $\begin{array}{c}1.03 \times 10^{6} \\
\left(2.52 \times 10^{3}\right)\end{array}$ & BDL & - & $\begin{array}{l}\text { Chimney - } \\
\text { outer }\end{array}$ \\
\hline EPR07-155 & $\begin{array}{c}1.05 \times 10^{5} \\
\left(8.21 \times 10^{3}\right)\end{array}$ & $\begin{array}{c}2.12 \times 10^{4} \\
\left(1.02 \times 10^{3}\right)\end{array}$ & 19.58 & $\begin{array}{c}\text { Chimney - } \\
\text { outer }\end{array}$ \\
\hline EPR07-174 & $\begin{array}{c}1.31 \times 10^{6} \\
\left(9.91 \times 10^{4}\right)\end{array}$ & $\begin{array}{c}2.74 \times 10^{3} \\
\left(3.26 \times 10^{2}\right)\end{array}$ & 0.21 & $\begin{array}{c}\text { Chimney - } \\
\text { outer \& inner }\end{array}$ \\
\hline
\end{tabular}

${ }_{\text {s.e.m. }}^{*}=$ standard error of the mean

${ }^{\S} \mathrm{BDL}=$ below detection limit 
Table 5.4. Results of qPCR assays to determine the occurrence and relative abundance of the DHVE2 in hydrothermal vent deposits from the Guaymas Basin. Values are the average of two replicates unless otherwise noted. Lower case letters next to sample names indicate paired samples.

\begin{tabular}{|c|c|c|c|c|}
\hline & $\begin{array}{l}\text { Archaeal 16S rRNA } \\
\text { gene copies per gram } \\
\text { of deposit (s.e.m.) }\end{array}$ & $\begin{array}{l}\text { DHVE2 16S rRNA } \\
\text { gene copies per gram } \\
\text { of deposit (s.e.m.) }\end{array}$ & $\begin{array}{l}\text { Proportion of } \\
\text { DHVE2 16S } \\
\text { rRNA gene } \\
\text { copies }(\%)\end{array}$ & $\begin{array}{l}\text { Deposit type- } \\
\text { sample } \\
\text { location }\end{array}$ \\
\hline Guay09-1 & $\begin{array}{c}2.59 \times 10^{5} \\
\left(6.56 \times 10^{3}\right)\end{array}$ & $\mathrm{BDL}^{\S}$ & - & $\begin{array}{l}\text { Flange - } \\
\text { top/lip }\end{array}$ \\
\hline Guay09-31 & $\begin{array}{c}1.92 \times 10^{7} \\
\left(1.64 \times 10^{5}\right)\end{array}$ & $\begin{array}{c}1.47 \times 10^{5} \\
\left(1.01 \times 10^{4}\right)\end{array}$ & 0.76 & $\begin{array}{c}\text { Flange - } \\
\text { top/lip }\end{array}$ \\
\hline Guay09-56 & $\begin{array}{c}1.95 \times 10^{8} \\
\left(1.43 \times 10^{7}\right)\end{array}$ & $\begin{array}{c}2.63 \times 10^{6} \\
\left(1.89 \times 10^{5}\right)\end{array}$ & 1.35 & $\begin{array}{c}\text { Chimney - } \\
\text { outer }\end{array}$ \\
\hline Guay09-45 & $\begin{array}{c}8.13 \times 10^{7} \\
\left(1.60 \times 10^{7}\right)\end{array}$ & $\begin{array}{l}3.10 \times 10^{5} \\
\left(5.47 \times 10^{3}\right)\end{array}$ & 0.38 & $\begin{array}{l}\text { Chimney - } \\
\text { outer }\end{array}$ \\
\hline Guay09-70 & $\begin{array}{c}6.66 \times 10^{4} \\
\left(4.80 \times 10^{3}\right)\end{array}$ & $\mathrm{BDL}$ & - & $\begin{array}{c}\text { Chimney - } \\
\text { outer }\end{array}$ \\
\hline Guay09-99 & $\begin{array}{c}4.88 \times 10^{4} \\
\left(1.02 \times 10^{4}\right)\end{array}$ & BDL & - & $\begin{array}{c}\text { Chimney - } \\
\text { outer }\end{array}$ \\
\hline Guay09-146 & $\begin{array}{c}2.84 \times 10^{4} \\
\left(2.77 \times 10^{3}\right)\end{array}$ & $\mathrm{BDL}$ & - & $\begin{array}{c}\text { Flange - } \\
\text { whole }\end{array}$ \\
\hline Guay09-173 & $\begin{array}{c}1.27 \times 10^{7} \\
\left(4.00 \times 10^{6}\right)\end{array}$ & $\begin{array}{c}6.99 \times 10^{5} \\
\left(1.43 \times 10^{5}\right)\end{array}$ & 5.50 & $\begin{array}{c}\text { Chimney - } \\
\text { outer }\end{array}$ \\
\hline Guay09-205 & $\begin{array}{r}4.13 \times 10^{7} \\
\left(1.08 \times 10^{7}\right)\end{array}$ & $\begin{array}{r}3.42 \times 10^{6} \\
\left(7.05 \times 10^{5}\right)\end{array}$ & 8.27 & $\begin{array}{l}\text { Chimney - } \\
\text { outer }\end{array}$ \\
\hline Guay09-127 & $\begin{array}{c}1.54 \times 10^{4} \\
\left(1.25 \times 10^{3}\right)\end{array}$ & BDL & - & $\begin{array}{l}\text { Flange - } \\
\text { whole }\end{array}$ \\
\hline Guay09-138 & $\begin{array}{c}1.93 \times 10^{4} \\
\left(4.87 \times 10^{2}\right)\end{array}$ & $\mathrm{BDL}$ & - & $\begin{array}{l}\text { Flange - } \\
\text { whole }\end{array}$ \\
\hline Guay09-190 & $\begin{array}{c}4.84 \times 10^{7} \\
\left(1.49 \times 10^{7}\right)\end{array}$ & $\begin{array}{c}1.27 \times 10^{5} \\
\left(9.27 \times 10^{4}\right)\end{array}$ & 0.26 & $\begin{array}{c}\text { Chimney - } \\
\text { outer }\end{array}$ \\
\hline Guay09-159 & $\begin{array}{c}3.74 \times 10^{6} \\
\left(1.45 \times 10^{5}\right)\end{array}$ & $\begin{array}{c}2.50 \times 10^{4} \\
\left(4.32 \times 10^{3}\right)\end{array}$ & 0.67 & $\begin{array}{l}\text { Chimney - } \\
\text { whole }\end{array}$ \\
\hline Guay09-228 & $\begin{array}{c}1.23 \times 10^{4} \\
\left(2.96 \times 10^{3}\right)\end{array}$ & $\mathrm{BDL}$ & - & $\begin{array}{c}\text { Chimney - } \\
\text { whole }\end{array}$ \\
\hline Guay09-244 & $\begin{array}{c}2.50 \times 10^{7} \\
\left(1.59 \times 10^{6}\right)\end{array}$ & $\begin{array}{c}1.42 \times 10^{6} \\
\left(6.05 \times 10^{4}\right)\end{array}$ & 5.68 & $\begin{array}{c}\text { Chimney - } \\
\text { outer }\end{array}$ \\
\hline Guay09-237 & $\begin{array}{c}4.38 \times 10^{8} \\
\left(1.13 \times 10^{8}\right)\end{array}$ & $\begin{array}{c}1.85 \times 10^{6} \\
\left(1.44 \times 10^{5}\right)\end{array}$ & 0.42 & $\begin{array}{l}\text { Chimney - } \\
\text { outer }\end{array}$ \\
\hline Guay09-258a & $\begin{array}{c}7.57 \times 10^{7} \\
\left(1.03 \times 10^{7}\right)\end{array}$ & $\begin{array}{c}5.89 \times 10^{6} \\
\left(5.08 \times 10^{6}\right)\end{array}$ & 7.78 & $\begin{array}{l}\text { Pagoda - } \\
\text { outer }\end{array}$ \\
\hline
\end{tabular}




\begin{tabular}{|c|c|c|c|c|}
\hline Guay09-264a & $\begin{array}{c}2.99 \times 10^{7} \\
\left(2.17 \times 10^{6}\right)\end{array}$ & $\begin{array}{c}3.17 \times 10^{6} \\
\left(1.71 \times 10^{5}\right)\end{array}$ & 10.58 & $\begin{array}{l}\text { Flange of } \\
\text { Pagoda - } \\
\text { top/lip }\end{array}$ \\
\hline Guay09-327 & $\begin{array}{c}5.72 \times 10^{3} \\
\left(8.84 \times 10^{2}\right)\end{array}$ & $\mathrm{BDL}$ & - & $\begin{array}{c}\text { Flange - } \\
\text { whole }\end{array}$ \\
\hline Guay09-314 & $\begin{array}{c}1.52 \times 10^{5} \\
\left(2.02 \times 10^{3}\right)\end{array}$ & BDL & - & Flange - top \\
\hline Guay09-302 & $\begin{array}{c}1.52 \times 10^{4} \\
\left(2.85 \times 10^{2}\right)\end{array}$ & $\mathrm{BDL}$ & - & $\begin{array}{c}\text { Flange - } \\
\text { whole }\end{array}$ \\
\hline Guay09-289 & $\begin{array}{c}3.75 \times 10^{6} \\
\left(2.08 \times 10^{4}\right)\end{array}$ & $\begin{array}{c}7.35 \times 10^{3} \\
\left(1.02 \times 10^{3}\right)\end{array}$ & 0.20 & Flange - top \\
\hline Guay09-363 & $\begin{array}{c}3.86 \times 10^{5} \\
\left(5.87 \times 10^{4}\right)\end{array}$ & $\mathrm{BDL}$ & - & $\begin{array}{c}\text { Chimney - } \\
\text { outer }\end{array}$ \\
\hline Guay09-439 & $\begin{array}{l}1.87 \times 10^{4} \\
(\mathrm{NA})^{*}\end{array}$ & $\mathrm{BDL}$ & - & $\begin{array}{c}\text { Chimney - } \\
\text { outer }\end{array}$ \\
\hline Guay09-441b & $\begin{array}{c}4.73 \times 10^{8} \\
\left(1.73 \times 10^{7}\right)\end{array}$ & $\begin{array}{c}3.05 \times 10^{4} \\
\left(4.87 \times 10^{3}\right)\end{array}$ & 0.01 & $\begin{array}{l}\text { Chimney - } \\
\text { outer brown }\end{array}$ \\
\hline Guay09-442b & $\begin{array}{c}3.06 \times 10^{4} \\
\left(2.21 \times 10^{3}\right)\end{array}$ & $\mathrm{BDL}$ & - & $\begin{array}{l}\text { Chimney - } \\
\text { outer white }\end{array}$ \\
\hline Guay09-452 & $\begin{array}{c}1.46 \times 10^{5} \\
\left(4.86 \times 10^{3}\right)\end{array}$ & $\mathrm{BDL}$ & - & Flange - top \\
\hline
\end{tabular}


Table 5.5. Results of qPCR assays to determine the occurrence and relative abundance of the DHVE2 in hydrothermal vent deposits from the Mid-Atlantic Ridge. Values are the average of two replicates unless otherwise noted. Lower case letters next to sample names indicate paired samples.

\begin{tabular}{|c|c|c|c|c|}
\hline & $\begin{array}{l}\text { Archaeal } 16 \mathrm{~S} \text { rRNA } \\
\text { gene copies per gram } \\
\text { of deposit (s.e.m.) }\end{array}$ & $\begin{array}{l}\text { DHVE2 16S rRNA } \\
\text { gene copies per gram } \\
\text { of deposit (s.e.m.) }\end{array}$ & $\begin{array}{l}\text { Proportion of } \\
\text { DHVE2 16S } \\
\text { rRNA gene } \\
\text { copies }(\%)\end{array}$ & $\begin{array}{l}\text { Deposit type } \\
\text { - sample } \\
\text { location }\end{array}$ \\
\hline Rainbow-2a & $\begin{array}{c}4.13 \times 10^{7} \\
\left(3.34 \times 10^{6}\right)\end{array}$ & $\begin{array}{c}1.06 \times 10^{5} \\
\left(4.71 \times 10^{3}\right)\end{array}$ & 0.26 & $\begin{array}{c}\text { Chimney - } \\
\text { outer }\end{array}$ \\
\hline Rainbow-3a & $\begin{array}{c}5.16 \times 10^{6} \\
\left(6.23 \times 10^{4}\right)\end{array}$ & $\begin{array}{c}3.84 \times 10^{4} \\
\left(1.63 \times 10^{4}\right)\end{array}$ & 0.74 & $\begin{array}{l}\text { Chimney - } \\
\text { inner }\end{array}$ \\
\hline Rainbow-103 & $\begin{array}{c}2.60 \times 10^{5} \\
\left(4.39 \times 10^{4}\right)\end{array}$ & $\mathrm{BDL}^{\S}$ & - & $\begin{array}{c}\text { Chimney - } \\
\text { whole }\end{array}$ \\
\hline Rainbow-158 & $\begin{array}{c}3.67 \times 10^{5} \\
\left(3.32 \times 10^{5}\right)\end{array}$ & BDL & - & $\begin{array}{l}\text { Chimney - } \\
\text { inner }\end{array}$ \\
\hline Rainbow-165 & $\begin{array}{c}4.74 \times 10^{6} \\
\left(4.71 \times 10^{5}\right)\end{array}$ & $\begin{array}{c}4.48 \times 10^{3} \\
\left(1.50 \times 10^{2}\right)\end{array}$ & 0.09 & $\begin{array}{c}\text { Chimney - } \\
\text { outer }\end{array}$ \\
\hline Rainbow-177b & $\begin{array}{c}5.14 \times 10^{7} \\
\left(1.31 \times 10^{5}\right)\end{array}$ & $\begin{array}{c}3.00 \times 10^{4} \\
\left(1.23 \times 10^{3}\right)\end{array}$ & 0.06 & $\begin{array}{c}\text { Chimney - } \\
\text { outer }\end{array}$ \\
\hline Rainbow-183b & $\begin{array}{c}2.70 \times 10^{5} \\
\left(7.10 \times 10^{4}\right)\end{array}$ & BDL & - & $\begin{array}{c}\text { Chimney - } \\
\text { inner }\end{array}$ \\
\hline Rainbow-5c & $\begin{array}{c}7.99 \times 10^{6} \\
\left(1.59 \times 10^{5}\right)\end{array}$ & $\begin{array}{c}2.09 \times 10^{4} \\
\left(1.27 \times 10^{3}\right)\end{array}$ & 0.26 & $\begin{array}{c}\text { Chimney - } \\
\text { outer }\end{array}$ \\
\hline Rainbow-6c & $\begin{array}{c}4.54 \times 10^{7} \\
\left(1.05 \times 10^{6}\right)\end{array}$ & $\begin{array}{c}9.41 \times 10^{4} \\
\left(2.06 \times 10^{4}\right)\end{array}$ & 0.21 & $\begin{array}{l}\text { Chimney - } \\
\text { inner }\end{array}$ \\
\hline Rainbow-217 & $\begin{array}{c}1.82 \times 10^{7} \\
\left(2.58 \times 10^{6}\right)\end{array}$ & $\begin{array}{c}3.91 \times 10^{4} \\
\left(1.08 \times 10^{4}\right)\end{array}$ & 0.21 & $\begin{array}{c}\text { Chimney - } \\
\text { whole }\end{array}$ \\
\hline Rainbow-231d & $\begin{array}{r}8.03 \times 10^{7} \\
\left(7.60 \times 10^{7}\right)\end{array}$ & $\begin{array}{l}2.60 \times 10^{4} \\
\left(2.38 \times 10^{3}\right)\end{array}$ & 0.03 & $\begin{array}{l}\text { Chimney - } \\
\text { outer }\end{array}$ \\
\hline Rainbow-241d & $\begin{array}{c}2.28 \times 10^{6} \\
\left(3.33 \times 10^{5}\right)\end{array}$ & BDL & - & $\begin{array}{c}\text { Chimney - } \\
\text { inner }\end{array}$ \\
\hline Lucky Strike-7 & $\begin{array}{r}4.33 \times 10^{6} \\
\left(6.40 \times 10^{5}\right)\end{array}$ & $\begin{array}{c}3.60 \times 10^{5} \\
\left(3.28 \times 10^{2}\right)\end{array}$ & 8.33 & $\begin{array}{c}\text { Chimney - } \\
\text { outer }\end{array}$ \\
\hline Lucky Strike-304 & $\begin{array}{c}1.00 \times 10^{6} \\
\left(4.99 \times 10^{4}\right)\end{array}$ & $\begin{array}{c}3.60 \times 10^{5} \\
\left(2.96 \times 10^{4}\right)\end{array}$ & 35.91 & $\begin{array}{c}\text { Flange - } \\
\text { bottom }\end{array}$ \\
\hline Lucky Strike-333 & $\begin{array}{c}5.34 \times 10^{4} \\
\left(3.69 \times 10^{3}\right)\end{array}$ & $\begin{array}{c}6.51 \times 10^{3} \\
\left(5.41 \times 10^{2}\right)\end{array}$ & 12.20 & $\begin{array}{c}\text { Chimney - } \\
\text { outer }\end{array}$ \\
\hline Lucky Strike-8 & $\begin{array}{c}2.61 \times 10^{5} \\
\left(2.52 \times 10^{3}\right)\end{array}$ & $\begin{array}{c}1.03 \times 10^{5} \\
\left(9.24 \times 10^{3}\right)\end{array}$ & 39.48 & $\begin{array}{c}\text { Flange - } \\
\text { bottom }\end{array}$ \\
\hline Lucky Strike-365 & $\begin{array}{c}5.40 \times 10^{5} \\
\left(3.60 \times 10^{4}\right)\end{array}$ & $\begin{array}{c}4.17 \times 10^{4} \\
\left(9.84 \times 10^{1}\right)\end{array}$ & 7.72 & $\begin{array}{c}\text { Chimney - } \\
\text { outer }\end{array}$ \\
\hline
\end{tabular}




\begin{tabular}{|c|c|c|c|c|}
\hline Lucky Strike-371 & $\begin{array}{c}1.45 \times 10^{4} \\
\left(4.72 \times 10^{3}\right)\end{array}$ & BDL & - & $\begin{array}{c}\text { Chimney - } \\
\text { outer }\end{array}$ \\
\hline Lucky Strike-11 & $\begin{array}{c}2.86 \times 10^{4} \\
\left(1.37 \times 10^{4}\right)\end{array}$ & BDL & - & $\begin{array}{c}\text { Chimney - } \\
\text { whole }\end{array}$ \\
\hline Lucky Strike-449 & $\begin{array}{c}2.93 \times 10^{4} \\
\left(4.27 \times 10^{2}\right)\end{array}$ & $\begin{array}{c}9.14 \times 10^{3} \\
\left(1.45 \times 10^{3}\right)\end{array}$ & 31.24 & $\begin{array}{l}\text { Flange - } \\
\text { bottom }\end{array}$ \\
\hline Lucky Strike-460 & $\begin{array}{c}6.95 \times 10^{3} \\
\left(2.21 \times 10^{3}\right)\end{array}$ & BDL & - & $\begin{array}{c}\text { Chimney - } \\
\text { outer }\end{array}$ \\
\hline Lucky Strike-12 & $\begin{array}{c}1.50 \times 10^{5} \\
\left(7.22 \times 10^{3}\right)\end{array}$ & $\begin{array}{c}5.83 \times 10^{4} \\
\left(3.01 \times 10^{3}\right)\end{array}$ & 38.79 & $\begin{array}{l}\text { Flange - } \\
\text { lip/edge }\end{array}$ \\
\hline TAG-593 & $\begin{array}{c}3.99 \times 10^{6} \\
\left(8.86 \times 10^{4}\right)\end{array}$ & $\begin{array}{c}9.52 \times 10^{3} \\
\left(8.88 \times 10^{2}\right)\end{array}$ & 0.03 & $\begin{array}{c}\text { Chimney - } \\
\text { outer }\end{array}$ \\
\hline TAG-604 & $\begin{array}{c}1.37 \times 10^{6} \\
\left(1.24 \times 10^{5}\right)\end{array}$ & $\begin{array}{c}1.86 \times 10^{4} \\
\left(6.38 \times 10^{2}\right)\end{array}$ & 1.36 & $\begin{array}{c}\text { Chimney - } \\
\text { whole }\end{array}$ \\
\hline TAG-625 & $\begin{array}{c}2.09 \times 10^{5} \\
\left(2.52 \times 10^{4}\right)\end{array}$ & BDL & - & $\begin{array}{c}\text { Chimney - } \\
\text { outer }\end{array}$ \\
\hline TAG-635 & $\begin{array}{c}2.70 \times 10^{8} \\
\left(3.04 \times 10^{7}\right)\end{array}$ & $\begin{array}{c}1.53 \times 10^{6} \\
(\mathrm{NA})^{*}\end{array}$ & 0.57 & $\begin{array}{c}\text { Chimney - } \\
\text { outer }\end{array}$ \\
\hline
\end{tabular}

${ }^{\ddagger}$ s.e.m. $=$ standard error of the mean

${ }^{\S} \mathrm{BDL}=$ below detection limit

${ }^{*}$ Denotes samples for which only one replicate had successful amplification. 
Table 5.6. Results of qPCR assays to determine the occurrence and relative abundance of the DHVE2 in hydrothermal vent deposits from the Eastern Lau Spreading Center. Values are the average of two replicates unless otherwise noted. Lower case letters next to sample names indicate paired samples.

\begin{tabular}{|c|c|c|c|c|}
\hline & $\begin{array}{l}\text { Archaeal 16S rRNA } \\
\text { gene copies per gram } \\
\text { of deposit (s.e.m.) }\end{array}$ & $\begin{array}{l}\text { DHVE2 16S rRNA } \\
\text { gene copies per gram } \\
\text { of deposit (s.e.m.) }\end{array}$ & $\begin{array}{l}\text { Proportion of } \\
\text { DHVE2 16S } \\
\text { rRNA gene } \\
\text { copies }(\%) \\
\end{array}$ & Deposit type \\
\hline Kilo Moana-3 & $\begin{array}{c}9.79 \times 10^{7} \\
\left(3.17 \times 10^{5}\right)\end{array}$ & $\begin{array}{c}7.74 \times 10^{5} \\
\left(5.25 \times 10^{3}\right)\end{array}$ & 0.79 & Flange - top \\
\hline Kilo Moana-19 & $\begin{array}{c}4.18 \times 10^{4} \\
\left(1.63 \times 10^{3}\right)\end{array}$ & BDL & - & Flange - top \\
\hline Kilo Moana-358 & $\begin{array}{c}4.80 \times 10^{7} \\
\left(3.13 \times 10^{6}\right)\end{array}$ & $\begin{array}{c}3.39 \times 10^{3} \\
\left(1.85 \times 10^{2}\right)\end{array}$ & 0.01 & $\begin{array}{l}\text { Flange - } \\
\text { top/lip }\end{array}$ \\
\hline Kilo Moana-36 & $\begin{array}{c}3.01 \times 10^{7} \\
\left(3.47 \times 10^{6}\right)\end{array}$ & $\begin{array}{c}7.70 \times 10^{4} \\
\left(8.68 \times 10^{3}\right)\end{array}$ & 0.26 & $\begin{array}{c}\text { Chimney - } \\
\text { outer }\end{array}$ \\
\hline Kilo Moana-371 & $\begin{array}{c}7.51 \times 10^{3} \\
\left(2.76 \times 10^{2}\right)\end{array}$ & BDL & - & Array+ \\
\hline Kilo Moana-399 & $\begin{array}{c}1.16 \times 10^{6} \\
\left(3.31 \times 10^{5}\right)\end{array}$ & $\begin{array}{c}1.04 \times 10^{4} \\
\left(1.50 \times 10^{3}\right)\end{array}$ & 0.90 & $\begin{array}{c}\text { Chimney - } \\
\text { outer }\end{array}$ \\
\hline Kilo Moana-413 & $\begin{array}{r}1.97 \times 10^{6} \\
\left(3.78 \times 10^{5}\right)\end{array}$ & BDL & - & Flange - top \\
\hline Kilo Moana-54 & $\begin{array}{c}4.98 \times 10^{7} \\
\left(1.11 \times 10^{7}\right)\end{array}$ & $\begin{array}{c}6.98 \times 10^{3} \\
\left(1.11 \times 10^{3}\right)\end{array}$ & 0.01 & Flange - top \\
\hline Tow Cam-1134 & $\begin{array}{r}4.17 \times 10^{7} \\
\left(1.09 \times 10^{7}\right)\end{array}$ & $\begin{array}{c}1.40 \times 10^{5} \\
\left(1.44 \times 10^{4}\right)\end{array}$ & 0.34 & $\begin{array}{c}\text { Chimney - } \\
\text { outer }\end{array}$ \\
\hline Tow Cam-1146 & $\begin{array}{c}3.78 \times 10^{4} \\
\left(3.60 \times 10^{3}\right)\end{array}$ & BDL & - & $\begin{array}{c}\text { Chimney - } \\
\text { outer }\end{array}$ \\
\hline Tow Cam-1175 & $\begin{array}{c}1.73 \times 10^{5} \\
\left(2.33 \times 10^{3}\right)\end{array}$ & BDL & - & $\begin{array}{c}\text { Chimney - } \\
\text { whole }\end{array}$ \\
\hline Tow Cam-1195 & $\begin{array}{c}2.07 \times 10^{5} \\
\left(1.04 \times 10^{4}\right)\end{array}$ & BDL & - & $\begin{array}{c}\text { Chimney - } \\
\text { outer }\end{array}$ \\
\hline Tow Cam-1768 & $\begin{array}{c}7.34 \times 10^{7} \\
\left(2.42 \times 10^{6}\right)\end{array}$ & $\begin{array}{r}1.20 \times 10^{6} \\
\left(2.33 \times 10^{5}\right)\end{array}$ & 1.63 & $\begin{array}{c}\text { Chimney - } \\
\text { outer }\end{array}$ \\
\hline Tow Cam-1774 & $\begin{array}{r}4.39 \times 10^{3} \\
\left(1.29 \times 10^{3}\right)\end{array}$ & BDL & - & $\begin{array}{c}\text { Chimney - } \\
\text { whole }\end{array}$ \\
\hline Tow Cam-1789 & $\begin{array}{r}1.85 \times 10^{7} \\
\left(5.65 \times 10^{5}\right)\end{array}$ & $\begin{array}{c}2.80 \times 10^{5} \\
\left(2.63 \times 10^{3}\right)\end{array}$ & 1.51 & $\begin{array}{c}\text { Chimney - } \\
\text { outer }\end{array}$ \\
\hline Tahi Moana-1255 & $\begin{array}{c}1.12 \times 10^{4} \\
\left(3.33 \times 10^{2}\right)\end{array}$ & BDL & - & Flange - top \\
\hline Tahi Moana-1274 & $\begin{array}{c}7.31 \times 10^{6} \\
\left(2.70 \times 10^{5}\right)\end{array}$ & $\begin{array}{c}7.10 \times 10^{5} \\
\left(1.13 \times 10^{5}\right)\end{array}$ & 9.71 & $\begin{array}{c}\text { Chimney - } \\
\text { outer }\end{array}$ \\
\hline
\end{tabular}




\begin{tabular}{|c|c|c|c|c|}
\hline Tahi Moana-1350 & $\begin{array}{c}7.66 \times 10^{7} \\
\left(2.43 \times 10^{6}\right)\end{array}$ & $\begin{array}{c}1.33 \times 10^{6} \\
\left(1.64 \times 10^{5}\right)\end{array}$ & 1.74 & $\begin{array}{l}\text { Chimney - } \\
\text { outer }\end{array}$ \\
\hline Tahi Moana-1360 & $\begin{array}{c}4.95 \times 10^{7} \\
\left(5.04 \times 10^{6}\right)\end{array}$ & $\begin{array}{c}7.42 \times 10^{5} \\
\left(5.22 \times 10^{4}\right)\end{array}$ & 1.50 & $\begin{array}{l}\text { Chimney - } \\
\text { outer }\end{array}$ \\
\hline Tahi Moana-1371 & $\begin{array}{c}1.38 \times 10^{7} \\
\left(9.10 \times 10^{5}\right)\end{array}$ & $\begin{array}{c}1.05 \times 10^{6} \\
\left(7.57 \times 10^{4}\right)\end{array}$ & 7.61 & $\begin{array}{l}\text { Chimney - } \\
\text { outer }\end{array}$ \\
\hline Tahi Moana-1381 & $\begin{array}{c}8.50 \times 10^{5} \\
\left(2.32 \times 10^{5}\right)\end{array}$ & $\begin{array}{c}1.22 \times 10^{4} \\
\left(3.44 \times 10^{3}\right)\end{array}$ & 1.44 & Flange - top \\
\hline Tahi Moana-1388 & $\begin{array}{c}1.61 \times 10^{7} \\
\left(9.25 \times 10^{5}\right)\end{array}$ & $\begin{array}{c}9.95 \times 10^{4} \\
\left(4.79 \times 10^{3}\right)\end{array}$ & 0.62 & $\begin{array}{c}\text { Chimney - } \\
\text { outer }\end{array}$ \\
\hline Tahi Moana-1403 & $\begin{array}{c}2.80 \times 10^{3} \\
\left(1.62 \times 10^{2}\right)\end{array}$ & BDL & - & Flange - top \\
\hline Tahi Moana-1464 & $\begin{array}{c}1.37 \times 10^{4} \\
\left(2.52 \times 10^{1}\right)\end{array}$ & BDL & - & $\begin{array}{l}\text { Chimney - } \\
\text { whole }\end{array}$ \\
\hline Tahi Moana-1476 & $\begin{array}{c}1.05 \times 10^{6} \\
\left(2.67 \times 10^{5}\right)\end{array}$ & $\begin{array}{c}9.16 \times 10^{3} \\
\left(2.29 \times 10^{3}\right)\end{array}$ & 0.87 & Flange - top \\
\hline Tahi Moana-1758 & $\begin{array}{c}7.63 \times 10^{5} \\
\left(2.77 \times 10^{5}\right)\end{array}$ & BDL & - & $\begin{array}{l}\text { Chimney - } \\
\text { outer }\end{array}$ \\
\hline ABE-139 & $\begin{array}{c}1.86 \times 10^{7} \\
\left(4.09 \times 10^{6}\right)\end{array}$ & $\begin{array}{c}1.34 \times 10^{5} \\
\left(1.85 \times 10^{4}\right)\end{array}$ & 0.72 & $\begin{array}{l}\text { Chimney - } \\
\text { outer }\end{array}$ \\
\hline ABE-180 & $\begin{array}{c}2.49 \times 10^{4} \\
\left(4.92 \times 10^{3}\right)\end{array}$ & BDL & - & $\begin{array}{l}\text { Chimney - } \\
\text { whole }\end{array}$ \\
\hline ABE-194 & $\begin{array}{c}9.70 \times 10^{3} \\
\left(3.45 \times 10^{3}\right)\end{array}$ & BDL & - & $\begin{array}{l}\text { Chimney - } \\
\text { whole }\end{array}$ \\
\hline ABE-206 & $\begin{array}{c}2.31 \times 10^{4} \\
\left(1.73 \times 10^{3}\right)\end{array}$ & BDL & - & $\begin{array}{c}\text { Chimney - } \\
\text { whole }\end{array}$ \\
\hline ABE-220 & $\begin{array}{c}1.12 \times 10^{7} \\
\left(2.11 \times 10^{6}\right)\end{array}$ & $\begin{array}{c}4.13 \times 10^{5} \\
\left(1.55 \times 10^{4}\right)\end{array}$ & 3.69 & $\begin{array}{l}\text { Chimney - } \\
\text { outer }\end{array}$ \\
\hline $\mathrm{ABE}-231 \mathrm{a}$ & $\begin{array}{c}1.84 \times 10^{7} \\
\left(2.63 \times 10^{4}\right)\end{array}$ & $\begin{array}{c}3.61 \times 10^{5} \\
\left(1.24 \times 10^{4}\right)\end{array}$ & 1.97 & $\begin{array}{l}\text { Chimney on } \\
\text { flange }\end{array}$ \\
\hline ABE-233a & $\begin{array}{c}2.09 \times 10^{6} \\
\left(6.16 \times 10^{5}\right)\end{array}$ & $\begin{array}{c}4.68 \times 10^{4} \\
\left(8.86 \times 10^{2}\right)\end{array}$ & 2.24 & $\begin{array}{l}\text { Chimney on } \\
\text { flange - outer }\end{array}$ \\
\hline ABE-250 & $\begin{array}{c}4.56 \times 10^{6} \\
\left(6.80 \times 10^{5}\right)\end{array}$ & $\begin{array}{c}1.07 \times 10^{5} \\
\left(1.45 \times 10^{4}\right)\end{array}$ & 2.35 & $\begin{array}{c}\text { Chimney - } \\
\text { outer }\end{array}$ \\
\hline ABE-309 & $\begin{array}{c}5.49 \times 10^{5} \\
\left(1.74 \times 10^{4}\right)\end{array}$ & $\begin{array}{c}2.89 \times 10^{3} \\
\left(1.29 \times 10^{3}\right)\end{array}$ & 0.53 & $\begin{array}{l}\text { Chimney - } \\
\text { outer }\end{array}$ \\
\hline ABE-91 & $\begin{array}{c}3.40 \times 10^{3} \\
\left(2.46 \times 10^{3}\right)\end{array}$ & BDL & - & $\begin{array}{l}\text { Chimney - } \\
\text { outer }\end{array}$ \\
\hline ABE-283 & $\begin{array}{c}2.44 \times 10^{7} \\
\left(1.28 \times 10^{6}\right)\end{array}$ & $\begin{array}{c}3.97 \times 10^{4} \\
\left(3.16 \times 10^{3}\right)\end{array}$ & 0.16 & $\begin{array}{l}\text { Chimney - } \\
\text { outer }\end{array}$ \\
\hline Tui Malila-1021 & $\begin{array}{c}2.52 \times 10^{5} \\
\left(3.88 \times 10^{4}\right)\end{array}$ & $\begin{array}{c}2.76 \times 10^{4} \\
\left(3.38 \times 10^{3}\right)\end{array}$ & 10.95 & $\begin{array}{l}\text { Chimney - } \\
\text { whole }\end{array}$ \\
\hline
\end{tabular}




\begin{tabular}{|c|c|c|c|c|}
\hline Tui Malila-1041 & $\begin{array}{c}3.19 \times 10^{5} \\
\left(6.11 \times 10^{4}\right)\end{array}$ & $\begin{array}{c}7.59 \times 10^{3} \\
\left(3.50 \times 10^{2}\right)\end{array}$ & 2.38 & $\begin{array}{l}\text { Flange - lip } \\
\text { edge }\end{array}$ \\
\hline Tui Malila-1059b & $\begin{array}{c}8.39 \times 10^{4} \\
\left(6.56 \times 10^{1}\right)\end{array}$ & $\begin{array}{c}5.96 \times 10^{4} \\
\left(6.52 \times 10^{3}\right)\end{array}$ & 71.06 & $\begin{array}{c}\text { Flange - } \\
\text { bottom }\end{array}$ \\
\hline Tui Malila-1066b & $\begin{array}{c}2.41 \times 10^{3} \\
\left(1.68 \times 10^{2}\right)\end{array}$ & BDL & - & $\begin{array}{l}\text { Flange - } \\
\text { lip/edge }\end{array}$ \\
\hline Tui Malila-1093 & $\begin{array}{c}1.66 \times 10^{5} \\
\left(2.23 \times 10^{4}\right)\end{array}$ & $\begin{array}{c}3.65 \times 10^{4} \\
\left(6.56 \times 10^{2}\right)\end{array}$ & 21.96 & Flange - top \\
\hline Tui Malila-1123 & $\begin{array}{c}4.24 \times 10^{3} \\
\left(8.30 \times 10^{2}\right)\end{array}$ & $\mathrm{BDL}$ & - & Flange - top \\
\hline Tui Malila-1540c & $\begin{array}{c}5.14 \times 10^{3} \\
\left(3.85 \times 10^{3}\right)\end{array}$ & BDL & - & $\begin{array}{c}\text { Flange - } \\
\text { bottom }\end{array}$ \\
\hline Tui Malila-1556c & $\begin{array}{c}2.77 \times 10^{4} \\
\left(1.71 \times 10^{3}\right)\end{array}$ & $\begin{array}{c}2.46 \times 10^{3} \\
\left(5.86 \times 10^{2}\right)\end{array}$ & 8.87 & $\begin{array}{l}\text { Flange - } \\
\text { lip/edge }\end{array}$ \\
\hline Tui Malila-1570 & $\begin{array}{c}5.67 \times 10^{4} \\
\left(4.09 \times 10^{3}\right)\end{array}$ & BDL & - & $\begin{array}{c}\text { Chimney - } \\
\text { whole }\end{array}$ \\
\hline Tui Malila-1600 & $\begin{array}{c}2.24 \times 10^{5} \\
\left(7.89 \times 10^{4}\right)\end{array}$ & $\begin{array}{c}4.47 \times 10^{3} \\
\left(1.34 \times 10^{3}\right)\end{array}$ & 1.99 & $\begin{array}{c}\text { Chimney - } \\
\text { outer }\end{array}$ \\
\hline Tui Malila-1623 & $\begin{array}{c}9.80 \times 10^{3} \\
\left(1.06 \times 10^{3}\right)\end{array}$ & BDL & - & $\begin{array}{c}\text { Chimney - } \\
\text { outer }\end{array}$ \\
\hline Tui Malila-1636 & $\begin{array}{c}3.22 \times 10^{4} \\
\left(9.98 \times 10^{3}\right)\end{array}$ & - & - & Array \\
\hline Tui Malila-828 & $\begin{array}{c}1.28 \times 10^{5} \\
\left(2.35 \times 10^{3}\right)\end{array}$ & $\mathrm{BDL}$ & - & $\begin{array}{c}\text { Chimney - } \\
\text { outer }\end{array}$ \\
\hline Tui Malila-833 & $\begin{array}{c}1.17 \times 10^{3} \\
(\mathrm{NA})^{*}\end{array}$ & $\mathrm{BDL}$ & - & $\begin{array}{c}\text { Chimney - } \\
\text { whole }\end{array}$ \\
\hline Tui Malila-858 & $\begin{array}{c}4.92 \times 10^{3} \\
\left(8.89 \times 10^{2}\right)\end{array}$ & BDL & - & $\begin{array}{c}\text { Flange - } \\
\text { bottom/lip }\end{array}$ \\
\hline Tui Malila-976 & $\begin{array}{c}1.86 \times 10^{4} \\
\left(6.20 \times 10^{3}\right)\end{array}$ & BDL & - & $\begin{array}{c}\text { Flange - } \\
\text { bottom }\end{array}$ \\
\hline Mariner-466 & $\begin{array}{c}1.93 \times 10^{6} \\
\left(1.73 \times 10^{5}\right)\end{array}$ & $\begin{array}{c}3.00 \times 10^{5} \\
\left(1.03 \times 10^{4}\right)\end{array}$ & 15.53 & $\begin{array}{c}\text { Chimney - } \\
\text { outer }\end{array}$ \\
\hline Mariner-496 & $\begin{array}{c}8.85 \times 10^{4} \\
\left(1.64 \times 10^{4}\right)\end{array}$ & $\begin{array}{c}5.30 \times 10^{4} \\
\left(2.47 \times 10^{3}\right)\end{array}$ & 59.88 & Flange - top \\
\hline Mariner-542 & $\begin{array}{c}2.69 \times 10^{6} \\
\left(2.96 \times 10^{5}\right)\end{array}$ & $\begin{array}{c}1.39 \times 10^{5} \\
\left(1.77 \times 10^{3}\right)\end{array}$ & 5.19 & $\begin{array}{c}\text { Chimney - } \\
\text { outer }\end{array}$ \\
\hline Mariner-568 & $\begin{array}{c}1.90 \times 10^{4} \\
\left(1.89 \times 10^{3}\right)\end{array}$ & BDL & - & $\begin{array}{c}\text { Chimney - } \\
\text { outer }\end{array}$ \\
\hline Mariner-576 & $\begin{array}{c}2.64 \times 10^{5} \\
\left(1.91 \times 10^{4}\right)\end{array}$ & $\begin{array}{c}4.23 \times 10^{3} \\
\left(3.55 \times 10^{2}\right)\end{array}$ & 1.60 & $\begin{array}{c}\text { Chimney - } \\
\text { outer }\end{array}$ \\
\hline Mariner-621 & $\begin{array}{c}5.40 \times 10^{4} \\
\left(7.97 \times 10^{3}\right)\end{array}$ & $\begin{array}{c}2.82 \times 10^{3} \\
\left(6.42 \times 10^{2}\right)\end{array}$ & 5.23 & Flange - top \\
\hline
\end{tabular}




\begin{tabular}{|c|c|c|c|c|}
\hline Mariner-646 & $\begin{array}{c}3.18 \times 10^{7} \\
\left(4.06 \times 10^{6}\right)\end{array}$ & ND & - & Flange - top \\
\hline Mariner-672 & $\begin{array}{c}9.23 \times 10^{5} \\
\left(3.59 \times 10^{4}\right)\end{array}$ & $\begin{array}{c}7.81 \times 10^{4} \\
\left(1.30 \times 10^{3}\right)\end{array}$ & 8.46 & Flange - top \\
\hline Mariner-719 & $\begin{array}{c}2.01 \times 10^{4} \\
\left(4.22 \times 10^{3}\right)\end{array}$ & BDL & - & $\begin{array}{c}\text { Chimney - } \\
\text { outer }\end{array}$ \\
\hline Mariner-729 & $\begin{array}{c}5.69 \times 10^{4} \\
\left(6.74 \times 10^{3}\right)\end{array}$ & $\begin{array}{c}4.00 \times 10^{3} \\
\left(5.75 \times 10^{2}\right)\end{array}$ & 7.03 & $\begin{array}{c}\text { Chimney - } \\
\text { outer }\end{array}$ \\
\hline Mariner-1493 & $\begin{array}{c}3.82 \times 10^{4} \\
\left(8.35 \times 10^{3}\right)\end{array}$ & $\begin{array}{c}2.08 \times 10^{3} \\
\left(6.68 \times 10^{2}\right)\end{array}$ & 5.45 & Flange - top \\
\hline Mariner-1652 & $\begin{array}{c}1.23 \times 10^{6} \\
\left(1.52 \times 10^{4}\right)\end{array}$ & $\begin{array}{c}4.66 \times 10^{5} \\
\left(6.38 \times 10^{4}\right)\end{array}$ & 37.93 & $\begin{array}{c}\text { Chimney - } \\
\text { outer }\end{array}$ \\
\hline Mariner-1684 & $\begin{array}{c}6.58 \times 10^{4} \\
\left(1.54 \times 10^{4}\right)\end{array}$ & $\begin{array}{c}4.06 \times 10^{4} \\
\left(7.80 \times 10^{3}\right)\end{array}$ & 61.76 & Flange - top \\
\hline Mariner-1704 & $\begin{array}{c}2.26 \times 10^{4} \\
\left(8.43 \times 10^{3}\right)\end{array}$ & $\begin{array}{c}4.89 \times 10^{3} \\
\left(6.35 \times 10^{2}\right)\end{array}$ & 21.61 & Flange - top \\
\hline Mariner-1718 & $\begin{array}{c}8.00 \times 10^{6} \\
\left(2.11 \times 10^{6}\right)\end{array}$ & $\begin{array}{c}8.53 \times 10^{5} \\
\left(1.34 \times 10^{5}\right)\end{array}$ & 10.66 & $\begin{array}{c}\text { Chimney - } \\
\text { outer }\end{array}$ \\
\hline
\end{tabular}

For most of the deposits we collected, only the outer few millimeters were sampled as this is where the majority of microorganisms are found (Takai et al., 2001; Schrenk et al., 2003; Nakagawa et al., 2005d; Kormas et al., 2006; Nunoura and Takai, 2009). However, for some of the deposits, we sampled exterior and interior sections of chimneys and, for flanges, different spatial areas on the top, bottom and lip/edge. (Tables 5.3-5.6). As a result of this sampling strategy, we have paired samples from a few deposits that illustrate the spatial variability of the DHVE2 within individual deposits. Spatial variability on a deposit is perhaps best illustrated by a flange structure collected from the Tui Malila vent field along the ELSC. On the bottom of this deposit, the DHVE2 comprised over $70 \%$ of the archaeal $16 \mathrm{~S}$ rRNA gene sequences detected (Tui Malila-1059) while they were undetectable on the lip/edge (Tui Malila-1066). 
These observations illustrate the spatial variability of the DHVE2 in individual deposits. Spatial variability on/in a deposit can be shaped by a number of factors including heterogeneous wall thickness, deposit mineralogy and fluid flow rate.

\section{Co-occurrence patterns of the DHVE2}

In previous studies, bar-coded pyrosequencing was used to characterize the archaeal communities of numerous vent deposits from geochemically and geographically distinct hydrothermal vent fields (MAR, Guaymas Basin, ELSC) (Flores et al., 2011). These large data sets provided an ideal resource to examine the cooccurrence of the DHVE2 with other archaeal lineages using Local Similarity Analysis (LSA). In total, three OTUs were identified as the DHVE2 (ID\#'s 727, 1148 and 1137) and contained 3557, 1389 and 120 sequences, respectively (Table 5.7). OTUs 727 and 1148 were present in $89 \%$ and $65 \%$ of samples, respectively, while 1137 was present in only $10 \%$ of samples. Using LSA, we found that the occurrence of clusters 727 and 1148 were positively correlated with one another but not with 1137 (Figure 5.2). Due to the low abundance, relatively rare occurrence and lack of correlation with the other DHVE2, results of LSA including cluster 1137 are not presented. An additional ten OTUs were positively correlated with both 727 and 1148, while five were negatively correlated (Figure 5.2). Interestingly, all negatively correlated OTUs were relatively abundant ( $\geq 1371$ sequences) and observed in most samples (present in 68 to $91 \%$ of deposits) while the positively correlated OTUs were generally less abundant $(\leq 2204)$ and rarer (present in 7 to $70 \%$ of deposits) (Table 5.8). 
Table 5.7. Results of local similarity analysis illustrating the co-occurrence of the DHVE2 with other archaeal OTUs.

\begin{tabular}{|c|c|c|c|}
\hline & $\begin{array}{l}\text { Number of } \\
\text { sequences }\end{array}$ & $\begin{array}{l}\text { Percentage } \\
\text { of deposits }\end{array}$ & $\begin{array}{l}\text { Lowest taxonomic classification with a } \\
\text { bootstrap value greater than } 50 \%(\%)\end{array}$ \\
\hline \multicolumn{4}{|c|}{$\begin{array}{l}\text { OTUs classified as } \\
\text { DHVE2 }\end{array}$} \\
\hline 727 & 3557 & 89.5 & Euryarchaeota (98) \\
\hline 1148 & 1389 & 65.0 & Euryarchaeota (92) \\
\hline 1137 & 120 & 10.5 & Euryarchaeota (100) \\
\hline \multicolumn{4}{|c|}{$\begin{array}{l}\text { OTUs positively } \\
\text { correlated with } 727 \\
\& 1148\end{array}$} \\
\hline 421 & 538 & 38.6 & Archaea (85) \\
\hline 544 & 171 & 38.6 & Ferroglobus (55) \\
\hline 547 & 190 & 15.8 & Euryarchaeota (93) \\
\hline 593 & 2204 & 65.0 & Euryarchaeota (93) \\
\hline 648 & 134 & 7.0 & Euryarchaeota (87) \\
\hline 677 & 101 & 29.8 & Euryarchaeota (52) \\
\hline 739 & 101 & 40.4 & Euryarchaeota (91) \\
\hline 927 & 990 & 70.2 & Thermogymnomonas (55) \\
\hline 1026 & 145 & 19.3 & Euryarchaeota (72) \\
\hline 1248 & 535 & 22.8 & Euryarchaeota (65) \\
\hline \multicolumn{4}{|c|}{$\begin{array}{l}\text { OTUs negatively } \\
\text { correlated with } 727 \\
\& 1148\end{array}$} \\
\hline 461 & 3539 & 71.9 & Archaeoglobus (98) \\
\hline 549 & 7143 & 68.4 & Thermoproteaceae (84) \\
\hline 594 & 6680 & 91.2 & Aeropyrum (53) \\
\hline 638 & 5105 & 77.2 & Desulfurococcales (98) \\
\hline 738 & 1371 & 68.4 & Staphylothermus (99) \\
\hline
\end{tabular}




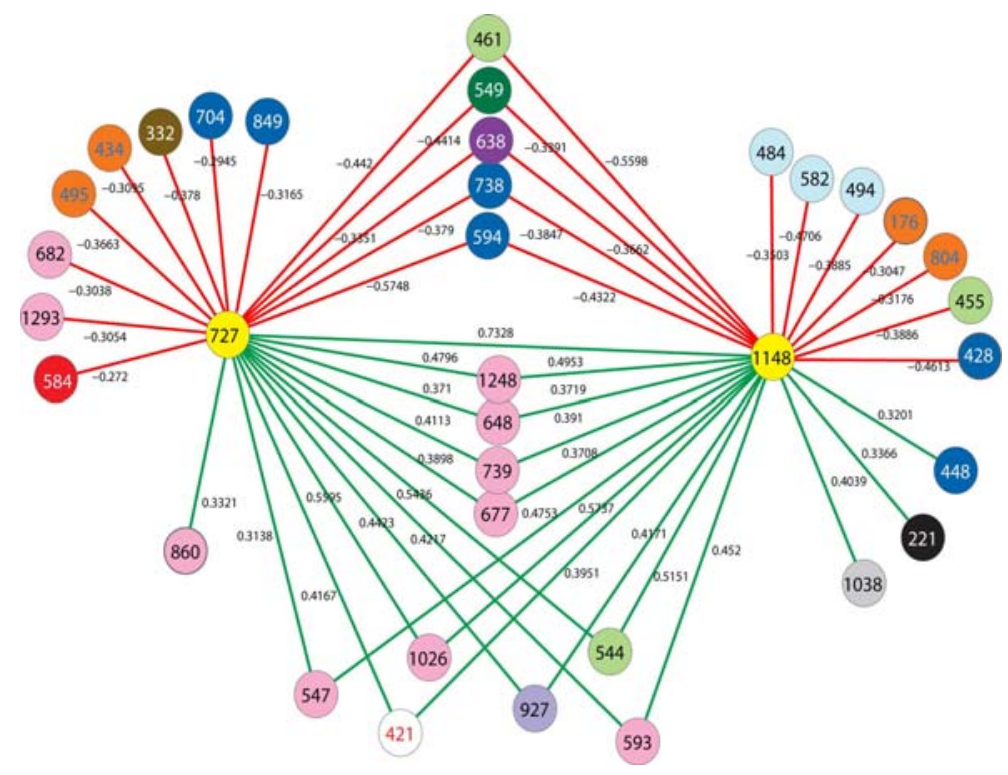

Figure 5.2. Results of local similarity analysis showing OTUs that are negatively (red lines) and positively (green lines) correlated with the DHVE2 (yellow circles). Circles represent OTUs and are colored according to family-level taxonomic classification by the RDP-classifier when possible. Color key is as follows: white $=$ unclassified Archaea, pink = unclassified Euryarchaeota, red $=$ unclassified Crenarchaeota, orange $=$ Nanoarchaeota, purple $=$ unclassified Desulfurococcales, lavender $=$ Thermoplasmatales, light green $=$ Archaeoglobaceae, light blue $=$ Methanococcaceae, grey $=$ Thermococcaceae, brown $=$ Thermofilaceae, black $=$ Pyrodictaceae, dark blue $=$ Desulfurococcaceae, dark green $=$ Thermoproteaceae.

The majority (9/10) of positively correlated OTUs were classified as Euryarchaeota (Figure 5.2, Table 5.7). However, most (7/9) could not be classified below the phylum making it difficult to speculate on potential ecological relationships between these OTUs and the DHVE2. Of the OTUs that could be classified beyond phylum, one was classified as Thermogymnomonas and the other Ferroglobus (Table 5.7). Only one Thermogymnomonas species is in culture but, it shares important phenotypic traits, like thermoacidophily, with A. boonei $\mathrm{T} 469^{\mathrm{T}}$ (Itoh et al., 2007). However, the cultured Thermogymnomonas species also differs from A. boonei $\mathrm{T} 469^{\mathrm{T}}$ 
in many significant ways as it is aerobic, utilizes sugars as carbon substrates and was isolated from a solfatara field in Japan. Whether deep-sea representatives of this lineage are phenotypically similar as the terrestrial isolate is unknown, but acidophily is at least a common trait of the Thermoplasmatales to which it belongs. The sole described Ferroglobus species, F. placidus, can both reduce (Tor et al., 2001) and oxidize (Hafenbradl et al., 1996) iron under different thermophilic conditions. Iron concentrations are generally high in deep-sea hydrothermal environments but are greatest when the $\mathrm{pH}$ of the fluids are low due to differences in solubility, suggesting that conditions which favor acidophiles may also favor thermophilic iron-oxidizers. It is therefore likely that these OTUs share the same acidophilic niche with the DHVE2 but utilize different carbon and/or energy sources which allow all to co-exist. These and the other positively correlated OTUs may also be involved in syntrophic relationships with the DHVE2 as others have proposed for fermentative Thermococcales (Bonch-Osmolovskaya and Stetter, 1991; Rinker and Kelly, 2000).

In contrast to the positively correlated OTUs, all negatively correlated OTUs were confidently classified to at least the order level and four of five were Crenarchaeota (Figure 5.2, Table 5.7). Some of the negatively correlated OTUs were related to organisms requiring oxidants from seawater. For example, the one euryarchaeotal OTU was confidently classified as Archaeoglobus which are thermophilic sulfate-reducers (Stetter, 1988; Burggraf et al., 1990; Beeder et al., 1994). Also, one of the crenarchaeotal OTUs was most closely related to Aeropyrum which are aerobic thermophiles (Sako et al., 1996). The only source for these oxidants in deep- 
sea hydrothermal environments is from seawater which upon mixing with hydrothermal fluids would raise fluid $\mathrm{pH}$, therefore inhibiting acidophiles. Cultivated organisms related to the negatively correlated OTUs are also not acidophilic and tended to have higher optimum growth temperatures than A. boonei $\mathrm{T} 469^{\mathrm{T}}$ (Boone et al., 2001). It appears then, that while the positively correlated OTUs may share the same acidophilic niche of the DHVE2 and are able to co-exist because of different carbon/energy sources, the negatively correlated OTUs require different physical conditions (neutral $\mathrm{pH}$, oxidizing conditions) that do not permit anaerobic thermoacidophiles to grow.

\section{Genetic diversity of cultivable DHVE2}

In order to better understand the phylogenetic diversity of the DHVE2, numerous enrichment cultures targeting thermoacidophilic microorganisms were initiated from samples collected in 2006 - 2009. Many of the enrichment cultures discussed above in chapter 4 that yielded thermoacidophilic Bacteria also yielded new DHVE2 isolates (Table 5.8). In total, 15 DHVE2 isolates were obtained with seven from the MAR (five from Lucky Strike, one from Rainbow, one from TAG), six from ELSC (one from Tui Malila, five from Mariner) and two from the EPR (Table 5.8). No isolates were obtained from the Guaymas Basin despite detection of the DHVE2 (by amplification of DHVE2 specific PCR primers) in two enrichments. Manipulations of medium $\mathrm{pH}$, temperature and organic substrates were performed to try and isolate the DHVE2 from Guaymas samples, but were unsuccessful as Thermococcus spp. would typically outgrow the DHVE2 under these conditions. 
Table 5.8. Hydrothermal vent deposits from which new DHVE2 isolates were obtained.

\begin{tabular}{|c|c|c|c|}
\hline Isolate name & $\begin{array}{c}\text { Vent field of isolation } \\
\text { (deposit type) }\end{array}$ & Location & Depth (m) \\
\hline Mar08-237a & $\begin{array}{l}\text { Rainbow } \\
\text { (chimney) }\end{array}$ & $\begin{array}{l}36^{\circ} 13.75625^{\prime} \mathrm{N} \\
33^{\circ} 54.11541^{\prime} \mathrm{W}\end{array}$ & 2275 \\
\hline Mar08-276 & $\begin{array}{l}\text { Lucky Strike } \\
\text { (chimney) }\end{array}$ & $\begin{array}{l}37^{\circ} 17.52494^{\prime} \mathrm{N} \\
32^{\circ} 16.50738^{\prime} \mathrm{W}\end{array}$ & 1617 \\
\hline Mar08-307 & $\begin{array}{l}\text { Lucky Strike } \\
\text { (flange) }\end{array}$ & $\begin{array}{l}37^{\circ} 17.5250^{\prime} \mathrm{N} \\
32^{\circ} 16.5058^{\prime} \mathrm{W}\end{array}$ & 1624 \\
\hline Mar08-339 & $\begin{array}{l}\text { Lucky Strike } \\
\text { (chimney) }\end{array}$ & $\begin{array}{l}37^{\circ} 17.45770^{\prime} \mathrm{N} \\
32^{\circ} 16.91245^{\prime} \mathrm{W}\end{array}$ & 1730 \\
\hline Mar08-361 & $\begin{array}{l}\text { Lucky Strike } \\
\text { (flange) }\end{array}$ & $\begin{array}{l}37^{\circ} 17.4528^{\prime} \mathrm{N} \\
32^{\circ} 16.9161^{\prime} \mathrm{W}\end{array}$ & 1730 \\
\hline Mar08-368 & $\begin{array}{l}\text { Lucky Strike } \\
\text { (chimney) }\end{array}$ & $\begin{array}{l}37^{\circ} 17.4998^{\prime} \mathrm{N} \\
32^{\circ} 16.6715^{\prime} \mathrm{W}\end{array}$ & 1721 \\
\hline Mar08-641 & $\begin{array}{l}\text { TAG } \\
\text { (chimney) }\end{array}$ & $\begin{array}{c}26^{\circ} 8.2043^{\prime} \mathrm{N} \\
44^{\circ} 49.5283^{\prime} \mathrm{W}\end{array}$ & 3621 \\
\hline EPR07-39 & $\begin{array}{c}9^{\circ} \mathrm{N} \\
\text { (chimney) }\end{array}$ & $\begin{array}{c}9^{\circ} 50.31366^{\prime} \mathrm{N} \\
104^{\circ} 17.48471^{\prime} \mathrm{W}\end{array}$ & 2510 \\
\hline EPR07-159 & $\begin{array}{c}9^{\circ} \mathrm{N} \\
\text { (chimney) }\end{array}$ & $\begin{array}{c}9^{\circ} 50.2876^{\prime} \mathrm{N} \\
104^{\circ} 17.4721^{\prime} \mathrm{W}\end{array}$ & 2507 \\
\hline Lau09-cd652 & $\begin{array}{l}\text { Mariner } \\
\text { (flange) }\end{array}$ & $\begin{array}{c}22^{\circ} 10.82942^{\prime} \mathrm{S} \\
176^{\circ} 36.10686^{\prime} \mathrm{W}\end{array}$ & 1919 \\
\hline Lau09-654 & $\begin{array}{l}\text { Mariner } \\
\text { (flange) }\end{array}$ & $\begin{array}{c}22^{\circ} 10.82942^{\prime} \mathrm{S} \\
176^{\circ} 36.10686^{\prime} \mathrm{W}\end{array}$ & 1919 \\
\hline Lau09-664 & $\begin{array}{l}\text { Mariner } \\
\text { (chimney) }\end{array}$ & $\begin{array}{c}22^{\circ} 10.80806^{\prime} \mathrm{S} \\
176^{\circ} 36.05562^{\prime} \mathrm{W}\end{array}$ & 1915 \\
\hline Lau09-781 & $\begin{array}{l}\text { Mariner } \\
\text { (chimney) }\end{array}$ & $\begin{array}{c}22^{\circ} 11.2751^{\prime} \mathrm{S} \\
176^{\circ} 36.0755^{\prime} \mathrm{W}\end{array}$ & 1919 \\
\hline Lau09-1128 & $\begin{array}{l}\text { Tui Malila } \\
\text { (flange) }\end{array}$ & $\begin{array}{c}22^{\circ} 0.1708^{\prime} \mathrm{S} \\
176^{\circ} 34.1066^{\prime} \mathrm{W}\end{array}$ & 1883 \\
\hline Lau09-cd1713 & $\begin{array}{l}\text { Mariner } \\
\text { (flange) }\end{array}$ & $\begin{array}{c}22^{\circ} 10.79920^{\prime} \mathrm{S} \\
176^{\circ} 36.06771^{\prime} \mathrm{W}\end{array}$ & 1911 \\
\hline
\end{tabular}

Despite large geographic distances between many of the vent fields, the genetic similarities of the 16S rRNA genes of the isolates were high. With the exception of strain Lau09-1128, all isolates shared greater than 97\% 16S rRNA gene sequence similarity with one another and A. boonei $\mathrm{T} 469^{\mathrm{T}}$ (Figure 5.3). This is similar to the diversity of Thermococcus species from different vent fields (e.g., Huber et al., 1995; Canganella et al., 1998; Holden et al., 2001; Huber et al., 2006) but quite different than what was observed for thermoacidophilic Bacteria as discussed in Chapter 4. Strain 
Lau09-1128 was $\geq 96 \%$ similar to all isolates but was most similar (> 97\% similar) to clone sequences (Figure 5.3). Despite the overall high sequence similarity of all organisms, isolates tended to cluster based on the vent field of isolation. Other thermophilic archaeal lineages, most notably the Sulfolobales and Thermococcales, do not exhibit such clear biogeographical trends using only $16 \mathrm{~S}$ rRNA gene sequences. Instead, other genes or intergenic regions must be used for biogeographical trends like these to be observed (Whitaker et al., 2003; Huber et al., 2006; Reno et al., 2009).

\section{Conclusion}

Results from this study show that the DHVE2 are ubiquitous in deep-sea hydrothermal environments and tend to co-occur with other Euryarchaeota. Assuming that all DHVE2 are thermoacidophilic, then thermoacidophily is an important physiological strategy for some microorganisms in these poorly understood ecosystems. Factors that seemed to influence the occurrence and abundance of the DHVE2 within an individual vent field include the age of the vent deposit (as this is indicative of the maturity of the microbial community), fluid mixing style and type of vent structure (chimney vs. flange). Other factors like deposit mineralogy, grazing by eukaryotes and viruses may also be influencing the biogeography of the DHVE2 but were not examined as part of this project. 


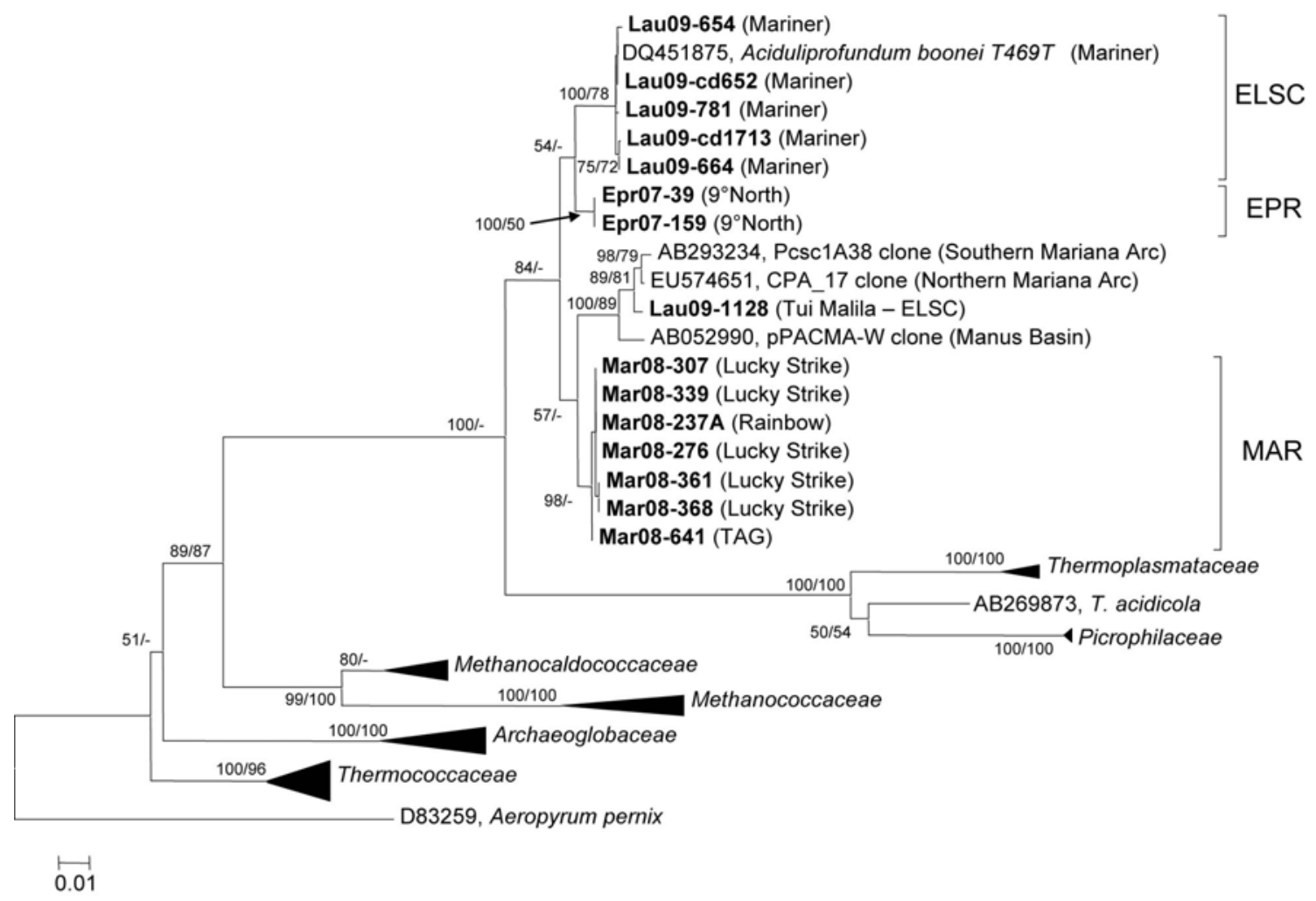

Figure 5.3. Neighbor-joining tree based on 16S rRNA gene sequence comparisons of 15 novel DHVE2 isolates and other archaeal families. Bootstrap percentages above $50 \%$ are shown firstly for the neighbor-joining analysis (based on 500 replicates) and secondly for the maximum-likelihood analysis (based on 100 replicates). The tree was generated considering only unambiguously aligned nucleotide position $(n=789)$. New isolates are shown in bold. The scale bar represents 0.01 changes per nucleotide position. T. acidocola in tree is Thermogymnomonas acidocola.

\section{Contributions}

For this project, I enriched and isolated novel members of the DHVE2 with Yitai Liu, performed all molecular and phylogenetic analyses of isolates, performed and analyzed qPCR results, mined pyrosequencing data, interpreted all results and wrote the manuscript for publication. 


\section{Chapter 6: Conclusion}

It has been nearly 35 years since deep-sea hydrothermal vents were first discovered. Over that time, numerous theoretical, observational and empirical studies have provided valuable information about the physiological potential and phylogenetic diversity of the microbial communities associated with these environments. However, we still have a limited understanding of the factors that control microbial biogeography in these systems. The studies presented in this dissertation aimed to improve our understanding of microbial biogeography of active hydrothermal vent deposits at multiple spatial scales and levels of biological organization.

In Chapter 2, bar-coded pyrosequencing was used to compare the archaeal and bacterial communities of two geochemically different vent fields along the MAR. The vent fields studied, Rainbow and Lucky Strike, are hosted atop different igneous substrates (peridotite vs. basalt) and, as a result, generate contrasting fluid chemistries that were predicted to influence microbial community composition (McCollom, 2007). Results show that the communities are indeed distinct between the two vent fields and the differences appear to be driven primarily by contrasting $\mathrm{H}_{2}$ concentrations in the hydrothermal fluids (Flores et al., 2011). The observed differences were supported by geochemical modeling that shows oxidizing conditions in the exterior of the $\mathrm{H}_{2}$-poor Lucky Strike deposits. To my knowledge, this is the first study in deep-sea vent microbial ecology where bar-coded pyrosequencing was used to show differences in both the archaeal and bacterial communities of a relatively large number of deposits from two geologically distinct vent fields. It is also the first to demonstrate a 
correlation between subsurface geological processes and microbial community structure at the vent field scale.

For Chapter 3, I extended the same pyrosequencing approach to compare the communities of over 30 deposits from six vent fields along the ELSC. Geologically, back-arc basins are different than mid-ocean ridge systems like the MAR and can generate contrasting fluid chemistries over relatively small geographic areas. Results from this study showed that the southernmost Mariner vent field hosted unique archaeal and bacterial communities. Differences in the Mariner communities were related to increased degassing of magma in the subsurface which results in more acidic, volatile rich fluids. Like the MAR study, this study highlights the coupling of geologic and microbial processes in deep-sea hydrothermal environments and provides an invaluable data-set that can be used to continue to unravel these associations.

While the studies presented in Chapters 2 and 3 identified geologic processes influencing microbial communities at the vent field scale, they also illustrated how many uncultivated lineages still exist in these environments. To help fill in these gaps, a targeted cultivation-based study was conducted in Chapter 4, resulting in the isolation and description of the first obligately thermoacidophilic Bacteria from deep-sea hydrothermal vents. Targeted cultivation efforts like this are becoming less common in microbial ecology as molecular techniques continue to dominate the field. However, as this study proves, numerous surprises remain about the physiological and metabolic potential of environmental microbes and without cultivation-based studies we will never 
be able to take full advantage of $16 \mathrm{~S}$ rRNA gene sequence data or appreciate the true diversity of our planet.

For Chapter 5, the biogeography of an important archaeal lineage, the thermoacidophilic DHVE2, was investigated using a combination of cultivationdependent and -independent techniques. Results showed that the DHVE2 are ubiquitous in deep-sea hydrothermal environments but their occurrence and abundance within an individual deposit depends on a number of factors. Targeted biogeographical studies like this can help us better understand constraints on certain physiological strategies in deep-sea hydrothermal environments. Furthermore, the use of correlation techniques like LSA could help identify shared niches between cultivated and uncultivated lineages allowing for more informed cultivation strategies targeting the uncultivated. Further detailed genomic analysis of the new isolates will also be able to identify similarities and differences between the biogeographical patterns observed in terrestrial thermoacidophilic Archaea.

In conclusion, deep-sea hydrothermal environments still represent one of the most fascinating and least understood environments on Earth. Future research should continue to build upon what I have presented here by applying similar sampling and sequencing strategies to capture the phylogenetic diversity of different hydrothermal vent environments. At the community level, the next step will be to determine the functional capabilities of these microbial communities through metagenomic and metatranscriptomic approaches. Targeted cultivation efforts and/or single cell sequencing techniques targeting novel lineages will also help to elucidate the functional 
capabilities of these communities. Eventually, these data can be integrated with various geological data (e.g., heat flux, fluid flow rates, geochemical composition of fluids, mineralogy, etc.) to provide more quantitative insights of microbial productivity of deep-sea hydrothermal environments in the context of the global ocean system. 


\section{References}

Alain, K., Querellou, J., Lesongeur, F., Pignet, P., Crassous, P., Raguenes, G. et al. (2002) Caminibacter hydrogeniphilus gen. nov., sp. nov., a novel thermophilic, hydrogen-oxidizing bacterium isolated from an East Pacific Rise hydrothermal vent. Int J Syst Evol Microbiol 52: 1317-1323.

Alt, J.C. (1995) Subseafloor Processes in Mid-Ocean Ridge Hydrothermal Systems. In Seafloor Hydrothermal Systems: Physical, Chemical, Biological, and Geological Interactions. Humphris, S.E., Zierenberg, R.A., Mullineaux, L.S., and Thomson, R.E. (eds). Washington, DC: American Geophysical Union, pp. 85-114.

Altschul, S.F., Gish, W., Miller, W., Myers, E.W., and Lipman, D.J. (1990) Basic local alignment search tool. J Mol Biol 215: 403-410.

Auguet, J.C., Barberan, A., and Casamayor, E.O. (2009) Global ecological patterns in uncultured Archaea. The ISME journal 4: 182-190.

Baker, B.J., Hugenholtz, P., Dawson, S.C., and Banfield, J.F. (2003) Extremely acidophilic protists from acid mine drainage host Rickettsiales-lineage endosymbionts that have intervening sequences in their 16S rRNA genes. Appl Environ Microbiol 69: 5512-5518.

Bautista-Zapanta, J.N., Arafat, H.H., Tanaka, K., Sawada, H., and Suzuki, K. (2009) Variation of $16 \mathrm{~S}-23 \mathrm{~S}$ internally transcribed spacer sequence and intervening 
sequence in rDNA among the three major Agrobacterium species. Microbiol Res 164: 604-612.

Beeder, J., Nilsen, R.K., Rosnes, J.T., Torsvik, T., and Lien, T. (1994) Archaeoglobus fulgidus isolated from hot North Sea oil field waters. Applied and Environmental Microbiology 60: 1227.

Benson, D.A., Karsch-Mizrachi, I., Lipman, D.J., Ostell, J., and Sayers, E.W. (2009) GenBank. Nucleic Acids Res 37: D26-31.

Bonch-Osmolovskaya, E.A., and Stetter, K.O. (1991) Interspecies hydrogen transfer in cocultures of thermophilic archaea. Systematic and applied microbiology 14: 205-208.

Boone, D.R., Castenholz, R.W., and Garrity, G.M. (2001) Bergey's manual of systematic bacteriology / George M. Garrity, editor-in-chief. New York: Springer.

Burggraf, S., Jannasch, H., Nicolaus, B., and Stetter, K. (1990) Archaeoglobus profundus sp. nov., represents a new species within the sulfate-reducing archaebacteria. Systematic and applied microbiology 13: 24-28.

Campbell, B.J., Engel, A.S., Porter, M.L., and Takai, K. (2006) The versatile epsilonproteobacteria: key players in sulphidic habitats. Nat Rev Microbiol 4: 458-468.

Campbell, B.J., Jeanthon, C., Kostka, J.E., Luther, G.W., 3rd, and Cary, S.C. (2001) Growth and phylogenetic properties of novel bacteria belonging to the epsilon subdivision of the Proteobacteria enriched from Alvinella pompejana and deepsea hydrothermal vents. Appl Environ Microbiol 67: 4566-4572. 
Canganella, F., Jones, W.J., Gambacorta, A., and Antranikian, G. (1998) Thermococcus guaymasensis sp. nov. and Thermococcus aggregans sp. nov., two novel thermophilic archaea isolated from the Guaymas Basin hydrothermal vent site. International Journal of Systematic and Evolutionary Microbiology 48: 11811185

Cavanaugh, C.M., Gardiner, S.L., Jones, M.L., Jannasch, H.W., and Waterbury, J.B. (1981) Prokaryotic Cells in the Hydrothermal Vent Tube Worm Riftia pachyptila Jones: Possible Chemoautotrophic Symbionts. Science 213: 340-342.

Chao, A., and Bunge, J. (2002) Estimating the number of species in a stochastic abundance model. Biometrics 58: 531-539.

Charlou, J., Donval, J., Douville, E., Jean-Baptiste, P., Radford-Knoery, J., Fouquet, Y. et al. (2000) Compared geochemical signatures and the evolution of Menez Gwen (37 50'N) and Lucky Strike (37 17'N) hydrothermal fluids, south of the Azores Triple Junction on the Mid-Atlantic Ridge. Chemical Geology 171: 4975.

Charlou, J.L., Donval, J.P., Fouquet, Y., Jean-Baptiste, P., and Holm, N. (2002) Geochemistry of high $\mathrm{H}_{2}$ and $\mathrm{CH}_{4}$ vent fluids issuing from ultramafic rocks at the Rainbow hydrothermal field (36 degrees 14 ' N, MAR). Chemical Geology 191: 345-359.

Claesson, M.J., O'Sullivan, O., Wang, Q., Nikkila, J., Marchesi, J.R., Smidt, H. et al. (2009) Comparative analysis of pyrosequencing and a phylogenetic microarray 
for exploring microbial community structures in the human distal intestine. PLoS One 4: e6669.

Clarke, K., and Gorley, R. (2006) PRIMER v6. User manual/tutorial Plymouth routine in mulitvariate ecological research Plymouth Marine Laboratory.

Cole, J.R., Wang, Q., Cardenas, E., Fish, J., Chai, B., Farris, R.J. et al. (2009) The Ribosomal Database Project: improved alignments and new tools for rRNA analysis. Nucleic Acids Res 37: D141-145.

Colwell, R.K., and Coddington, J.A. (1994) Estimating terrestrial biodiversity through extrapolation. Philos Trans R Soc Lond B Biol Sci 345: 101-118.

Corre, E., Reysenbach, A.L., and Prieur, D. (2001) Epsilon-proteobacterial diversity from a deep-sea hydrothermal vent on the Mid-Atlantic Ridge. FEMS Microbiol Lett 205: 329-335.

De Angelis, M., Lilley, M., and Baross, J. (1993) Methane oxidation in deep-sea hydrothermal plumes of the Endeavour Segment of the Juan de Fuca Ridge. Deep Sea Research Part I: Oceanographic Research Papers 40: 1169-1186.

Desbruyeres, D., Almeida, A., Biscoito, M., Comtet, T., Khripounoff, A., Le Bris, N. et al. (2000) A review of the distribution of hydrothermal vent communities along the northern Mid-Atlantic Ridge: dispersal vs. environmental controls. Hydrobiologia 440: 201-216.

Desbruyeres, D., Chevaldonné, P., Alayse, A.M., Jollivet, D., Lallier, F., JouinToulmond, C. et al. (1998) Biology and ecology of the "Pompeii worm"(Alvinella pompejana Desbruyeres and Laubier), a normal dweller of an 
extreme deep-sea environment: a synthesis of current knowledge and recent developments. Deep-Sea Research Part II 45: 383-422.

Desbruyeres, D., Biscoito, M., Caprais, J.C., Colaco, A., Comtet, T., Crassous, P. et al. (2001) Variations in deep-sea hydrothermal vent communities on the MidAtlantic Ridge near the Azores plateau. Deep-Sea Research Part IOceanographic Research Papers 48: 1325-1346.

Dewhirst, F.E., Shen, Z., Scimeca, M.S., Stokes, L.N., Boumenna, T., Chen, T. et al. (2005) Discordant 16S and 23S rRNA gene phylogenies for the genus Helicobacter: implications for phylogenetic inference and systematics. $J$ Bacteriol 187: 6106-6118.

Dhillon, A., Lever, M., Lloyd, K.G., Albert, D.B., Sogin, M.L., and Teske, A. (2005) Methanogen diversity evidenced by molecular characterization of methyl coenzyme M reductase A (mcrA) genes in hydrothermal sediments of the Guaymas Basin. Appl Environ Microbiol 71: 4592-4601.

Dick, G.J., Lee, Y.E., and Tebo, B.M. (2006) Manganese(II)-oxidizing Bacillus spores in Guaymas Basin hydrothermal sediments and plumes. Appl Environ Microbiol 72: 3184-3190.

Dieci, G., Preti, M., and Montanini, B. (2009) Eukaryotic snoRNAs: a paradigm for gene expression flexibility. Genomics 94: 83-88.

Douville, E., Charlou, J.L., Oelkers, E.H., Bienvenu, P., Colon, C.F.J., Donval, J.P. et al. (2002) The rainbow vent fluids (36 degrees 14 ' N, MAR): the influence of 
ultramafic rocks and phase separation on trace metal content in Mid-Atlantic Ridge hydrothermal fluids. Chemical Geology 184: 37-48.

Edwards, K.J. (2004) Formation and degradation of seafloor hydrothermal sulfide deposits. In Sulfur Biogeochemistry: Past and Present. Amend, J.P., Edwards, K.J., and Lyons, T.W. (eds). Boulder, CO: The Geological Society of America, pp. 83-96.

Edwards, K.J., Bach, W., and McCollom, T.M. (2005) Geomicrobiology in oceanography: microbe-mineral interactions at and below the seafloor. TRENDS in Microbiology 13: 449-456.

Edwards, K.J., McCollom, T.M., Konishi, H., and Buseck, P.R. (2003a) Seafloor bioalteration of sulfide minerals: results from in situ incubation studies. Geochimica Et Cosmochimica Acta 67: 2843-2856.

Edwards, K.J., Rogers, D.R., Wirsen, C.O., and McCollom, T.M. (2003b) Isolation and characterization of novel psychrophilic, neutrophilic, Fe-oxidizing, chemolithoautotrophic alpha- and gamma-proteobacteria from the deep sea. Appl Environ Microbiol 69: 2906-2913.

Felbeck, H. (1981) Chemoautotrophic Potential of the Hydrothermal Vent Tube Worm, Riftia pachyptila Jones (Vestimentifera). Science 213: 336-338.

Ferrera, I., Longhorn, S., Banta, A.B., Liu, Y., Preston, D., and Reysenbach, A.L. (2007) Diversity of 16S rRNA gene, ITS region and aclB gene of the Aquificales. Extremophiles 11: 57-64. 
Ferrini, V., Tivey, M., Carbotte, S., Martinez, F., and Roman, C. (2008) Variable morphologic expression of volcanic, tectonic, and hydrothermal processes at six hydrothermal vent fields in the Lau back-arc basin. Geochemistry Geophysics Geosystems 9: Q07022.

Flores, G.E., Campbell, J.H., Kirshtein, J.D., Meneghin, J., Podar, M., Steinberg, J.I. et al. (2011) Microbial Community Structure of Hydrothermal Deposits from Geochemically Different Vent Fields Along the Mid-Atlantic Ridge. Environ Microbiol. 13: no. doi: 10.1111/j.1462-2920.2011.02463.x

Foustoukos, D., Houghton, J., Seyfried, W., Sievert, S., and Cody, G. (2011) Kinetics of $\mathrm{H}_{2}-\mathrm{O}_{2}-\mathrm{H}_{2} \mathrm{O}$ redox equilibria and formation of metastable $\mathrm{H}_{2} \mathrm{O}_{2}$ under low temperature hydrothermal conditions. Geochimica Et Cosmochimica Acta. 75: 1594-1607.

Gamo, T., Ishibashi, J., Tsunogai, U., Okamura, K., and Chiba, H. (2006) Unique geochemistry of submarine hydrothermal fluids from arc-back-arc settings of the western Pacific. In Back-Arc Spreading Systems: Geological, Biological, Chemical, and Physical Interactions. Christie, D.M., Fisher, C.R., Lee, S.-M., and Givens, S. (eds): American Geophysical Union, pp. 147-161.

German, C., and Von Damm, K. (2004) Hydrothermal processes In Treatise on Geochemistry. Turekian, K.K., and Holland, H.D. (eds). New York, N. Y.: Elsevier, pp. 181-222. 
Glasauer, S., Langley, S., Boyanov, M., Lai, B., Kemner, K., and Beveridge, T.J. (2007) Mixed-valence cytoplasmic iron granules are linked to anaerobic respiration. Appl Environ Microbiol 73: 993-996.

Götz, D., Banta, A., Beveridge, T.J., Rushdi, A.I., Simoneit, B.R., and Reysenbach, A.L. (2002) Persephonella marina gen. nov., sp. nov. and Persephonella guaymasensis sp. nov., two novel, thermophilic, hydrogen-oxidizing microaerophiles from deep-sea hydrothermal vents. Int J Syst Evol Microbiol 52: $1349-1359$.

Hafenbradl, D., Keller, M., Dirmeier, R., Rachel, R., Roßnagel, P., Burggraf, S. et al. (1996) Ferroglobus placidus gen. nov., sp. nov., a novel hyperthermophilic archaeum that oxidizes $\mathrm{Fe}^{2+}$ at neutral $\mathrm{pH}$ under anoxic conditions. Archives of microbiology 166: 308-314.

Hamady, M., Lozupone, C., and Knight, R. (2010) Fast UniFrac: facilitating highthroughput phylogenetic analyses of microbial communities including analysis of pyrosequencing and PhyloChip data. ISME J 4: 17-27.

Harmsen, H., Prieur, D., and Jeanthon, C. (1997) Distribution of microorganisms in deep-sea hydrothermal vent chimneys investigated by whole-cell hybridization and enrichment culture of thermophilic subpopulations. Appl Environ Microbiol 63: $2876-2883$.

Hoek, J., Banta, A., Hubler, F., and Reysenbach, A. (2003) Microbial diversity of a sulphide spire located in the Edmond deep-sea hydrothermal vent field on the Central Indian Ridge. Geobiology 1: 119-127. 
Holden, J.F., Takai, K., Summit, M., Bolton, S., Zyskowski, J., and Baross, J.A. (2001) Diversity among three novel groups of hyperthermophilic deep-sea Thermococcus species from three sites in the northeastern Pacific Ocean. FEMS Microbiol Ecol 36: 51-60.

Huber, H., Hohn, M., Rachel, R., Fuchs, T., Wimmer, V., and Stetter, K. (2002a) A new phylum of Archaea represented by a nanosized hyperthermophilic symbiont. Nature 417: 63-67.

Huber, J., Cantin, H., Huse, S., Welch, D., Sogin, M., and Butterfield, D. (2010) Isolated communities of Epsilonproteobacteria in hydrothermal vent fluids of the Mariana Arc seamounts. FEMS microbiology ecology 73: 538-549.

Huber, J., Mark Welch, D., Morrison, H., Huse, S., Neal, P., Butterfield, D., and Sogin, M. (2007) Microbial population structures in the deep marine biosphere. Science 318: $97-100$.

Huber, J.A., Butterfield, D.A., and Baross, J.A. (2002b) Temporal changes in archaeal diversity and chemistry in a mid-ocean ridge subseafloor habitat. Appl Environ Microbiol 68: 1585-1594.

Huber, J.A., Butterfield, D.A., and Baross, J.A. (2006) Diversity and distribution of subseafloor Thermococcales populations in diffuse hydrothermal vents at an active deep-sea volcano in the northeast Pacific Ocean. Journal of Geophysical Research-Biogeosciences 111: G04016.

Huber, R., Stöhr, J., Hohenhaus, S., Rachel, R., Burggraf, S., Jannasch, H.W., and Stetter, K.O. (1995) Thermococcus chitonophagus sp. nov., a novel, chitin- 
degrading, hyperthermophilic archaeum from a deep-sea hydrothermal vent environment. Archives of microbiology 164: 255-264.

Humphris, S.E., Fornari, D.J., Scheirer, D.S., German, C.R., and Parson, L.M. (2002) Geotectonic setting of hydrothermal activity on the summit of Lucky Strike Seamount (37 degrees 17 ' N, Mid-Atlantic Ridge). Geochemistry Geophysics Geosystems 3: 1-24.

Hunter, R.C., and Beveridge, T.J. (2005) High-resolution visualization of Pseudomonas aeruginosa PAO1 biofilms by freeze-substitution transmission electron microscopy. J Bacteriol 187: 7619-7630.

Huse, S., Welch, D., Morrison, H., and Sogin, M. (2010) Ironing out the wrinkles in the rare biosphere through improved OTU clustering. Environmental microbiology 12: $1889-1898$.

Imachi, H., Sakai, S., Hirayama, H., Nakagawa, S., Nunoura, T., Takai, K., and Horikoshi, K. (2008) Exilispira thermophila gen. nov., sp. nov., an anaerobic, thermophilic spirochaete isolated from a deep-sea hydrothermal vent chimney. Int J Syst Evol Microbiol 58: 2258-2265.

Inagaki, F., Takai, K., Nealson, K.H., and Horikoshi, K. (2004) Sulfurovum lithotrophicum gen. nov., sp. nov., a novel sulfur-oxidizing chemolithoautotroph within the epsilon-Proteobacteria isolated from Okinawa Trough hydrothermal sediments. Int J Syst Evol Microbiol 54: 1477-1482.

Inagaki, F., Takai, K., Kobayashi, H., Nealson, K.H., and Horikoshi, K. (2003) Sulfurimonas autotrophica gen. nov., sp. nov., a novel sulfur-oxidizing epsilon- 
proteobacterium isolated from hydrothermal sediments in the Mid-Okinawa Trough. Int J Syst Evol Microbiol 53: 1801-1805.

Inagaki, F., Nunoura, T., Nakagawa, S., Teske, A., Lever, M., Lauer, A. et al. (2006) Biogeographical distribution and diversity of microbes in methane hydratebearing deep marine sediments on the Pacific Ocean Margin. Proc Natl Acad Sci 103: 2815-2820.

Itoh, T., Yoshikawa, N., and Takashina, T. (2007) Thermogymnomonas acidicola gen. nov., sp. nov., a novel thermoacidophilic, cell wall-less archaeon in the order Thermoplasmatales, isolated from a solfataric soil in Hakone, Japan. International Journal of Systematic and Evolutionary Microbiology 57: 25572561.

Itoh, T., Suzuki, K., Sanchez, P., and Nakase, T. (2003) Caldisphaera lagunensis gen. nov., sp. nov., a novel thermoacidophilic crenarchaeote isolated from a hot spring at Mt Maquiling, Philippines. International Journal of Systematic and Evolutionary Microbiology 53: 1149-1154.

Jannasch, H.W. (1995) Microbial Interactions with Hydrothermal Fluids. In Seafloor Hydrothermal Systems: Physical, Chemical, Biological, and Geological Interactions. Humphris, S.E., Zierenberg, R.A., Mullineaux, L.S., and Thomson, R.E. (eds). Washington, DC: American Geophysical Union, pp. 273-296.

Jones, M.L. (1981) Riftia pachyptila Jones: Observations on the Vestimentiferan Worm from the Galapagos Rift. Science 213: 333-336. 
Juniper, S.K., and Tebo, B.M. (1995) Microbe-Metal Interactions and Mineral Deposition at Hydrothermal Vents. In The Microbiology of Deep-Sea Hydrothermal Vents. Karl, D.M. (ed). Boca Raton, FL: CRC Press, pp. 219-253.

Kallmeyer, J., and Boetius, A. (2004) Effects of temperature and pressure on sulfate reduction and anaerobic oxidation of methane in hydrothermal sediments of Guaymas Basin. Appl Environ Microbiol 70: 1231-1233.

Karl, D.M. (ed) (1995a) The Microbiology of Deep-Sea Hydrothermal Vents. Boca Raton, FL: CRC Press.

Karl, D.M. (1995b) Ecology of Free-Living, Hydrothermal Vent Microbial Communities. In The Microbiology of Deep-Sea Hydrothermal Vents. Karl, D.M. (ed). Boca Raton, FL: CRC Press, pp. 35-124.

Kato, S., Takano, Y., Kakegawa, T., Oba, H., Inoue, K., Kobayashi, C. et al. (2010) Biogeography and biodiversity in sulfide structures of active and inactive vents at deep-sea hydrothermal fields of the Southern Mariana Trough. Appl Environ Microbiol 76: 2968-2979.

Kelley, D.S., Karson, J.A., Blackman, D.K., Fruh-Green, G.L., Butterfield, D.A., Lilley, M.D. et al. (2001) An off-axis hydrothermal vent field near the Mid-Atlantic Ridge at 30 degrees N. Nature 412: 145-149.

Kim, Y.J., Lee, H.S., Kim, E.S., Bae, S.S., Lim, J.K., Matsumi, R. et al. (2010) Formate-driven growth coupled with $\mathrm{H}_{2}$ production. Nature 467: 352-355. Kimura, H., Mori, K., Tashiro, T., Kato, K., Yamanaka, T., Ishibashi, J.I., and Hanada, S. (2010) Culture-Independent Estimation of Optimal and Maximum Growth 
Temperatures of Archaea in Subsurface Habitats Based on the G plus C Content in 16S rRNA Gene Sequences. Geomicrobiology Journal 27: 114-122.

Kormas, K.A., Tivey, M.K., Von Damm, K., and Teske, A. (2006) Bacterial and archaeal phylotypes associated with distinct mineralogical layers of a white smoker spire from a deep-sea hydrothermal vent site ( 9 degrees N, East Pacific Rise). Environ Microbiol 8: 909-920.

Lane, D.J. (1991) 16S/23S rRNA Sequencing. In Nucleic Acid Techniques in Bacterial Systematics. Stackebrandt, E., and Goodfellow, M. (eds). Chichester, West Sussex: John Wiley \& Sons Ltd., pp. 115-148.

Langmuir, C., Humphris, S., Fornari, D., VanDover, C., VonDamm, K., Tivey, M.K. et al. (1997) Hydrothermal vents near a mantle hot spot: The Lucky Strike vent field at 37 degrees $\mathrm{N}$ on the Mid-Atlantic Ridge. Earth and Planetary Science Letters 148: 69-91.

Lee, H.S., Kang, S.G., Bae, S.S., Lim, J.K., Cho, Y., Kim, Y.J. et al. (2008) The complete genome sequence of Thermococcus onnurineus NA1 reveals a mixed heterotrophic and carboxydotrophic metabolism. Journal of Bacteriology 190: 7491-7499.

Longnecker, K., and Reysenbach, A. (2001) Expansion of the geographic distribution of a novel lineage of epsilon-Proteobacteria to a hydrothermal vent site on the Southern East Pacific Rise. FEMS Microbiol Ecol 35: 287-293. 
Lozupone, C., Hamady, M., and Knight, R. (2006) UniFrac--an online tool for comparing microbial community diversity in a phylogenetic context. BMC Bioinformatics 7: 371 .

Ludwig, W., Strunk, O., Westram, R., Richter, L., Meier, H., Yadhukumar et al. (2004) ARB: a software environment for sequence data. Nucleic Acids Res 32: 13631371.

Marmur, J., and Doty, P. (1962) Determination of the base composition of deoxyribonucleic acid from its thermal denaturation temperature. Journal of Molecular Biology 5: 109-118.

Marques, A.F.A., Barriga, F., Chavagnac, V., and Fouquet, Y. (2006) Mineralogy, geochemistry, and $\mathrm{Nd}$ isotope composition of the Rainbow hydrothermal field, Mid-Atlantic Ridge. Mineralium Deposita 41: 52-67.

Martinez, F., Okino, K., Ohara, Y., Reysenbach, A.-L., and Goffredi, S.K. (2007) Backarc basins. Oceanography 20: 116-127.

McCliment, E.A., Voglesonger, K.M., O'Day, P.A., Dunn, E.E., Holloway, J.R., and Cary, S.C. (2006) Colonization of nascent, deep-sea hydrothermal vents by a novel Archaeal and Nanoarchaeal assemblage. Environ Microbiol 8: 114-125.

McCollom, T.M. (2000) Geochemical constraints on primary productivity in submarine hydrothermal vent plumes. Deep Sea Research Part I: Oceanographic Research Papers 47: 85-101. 
McCollom, T.M. (2007) Geochemical constraints on sources of metabolic energy for chemolithoautotrophy in ultramafic-hosted deep-sea hydrothermal systems. Astrobiology 7: 933-950.

McCollom, T.M., and Shock, E.L. (1997) Geochemical constraints on chemolithoautotrophic metabolism by microorganisms in seafloor hydrothermal systems. Geochimica Et Cosmochimica Acta 61: 4375-4391.

Minic, Z., and Herve, G. (2004) Biochemical and enzymological aspects of the symbiosis between the deep-sea tubeworm Riftia pachyptila and its bacterial endosymbiont. Eur J Biochem 271: 3093-3102.

Miroshnichenko, M., Kostrikina, N., L'Haridon, S., Jeanthon, C., Hippe, H., Stackebrandt, E., and Bonch-Osmolovskaya, E. (2002) Nautilia lithotrophica gen. nov., sp. nov., a thermophilic sulfur-reducing epsilon-proteobacterium isolated from a deep-sea hydrothermal vent. International Journal of Systematic and Evolutionary Microbiology 52: 1299-1304.

Miroshnichenko, M.L., and Bonch-Osmolovskaya, E.A. (2006) Recent developments in the thermophilic microbiology of deep-sea hydrothermal vents. Extremophiles 10: $85-96$.

Miroshnichenko, M.L., Rainey, F.A., Rhode, M., and Bonch-Osmolovskaya, E.A. (1999) Hippea maritima gen. nov., sp. nov., a new genus of thermophilic, sulfur-reducing bacterium from submarine hot vents. Int J Syst Bacteriol 49: 1033-1038. 
Miroshnichenko, M.L., Rainey, F.A., Hippe, H., Chernyh, N.A., Kostrikina, N.A., and Bonch-Osmolovskaya, E.A. (1998) Desulfurella kamchatkensis sp. nov. and Desulfurella propionica sp. nov., new sulfur-respiring thermophilic bacteria from Kamchatka thermal environments. Int J Syst Bacteriol 48: 475-479.

Miroshnichenko, M.L., L'Haridon, S., Schumann, P., Spring, S., Bonch-Osmolovskaya, E.A., Jeanthon, C., and Stackebrandt, E. (2004) Caminibacter profundus sp. nov., a novel thermophile of Nautiliales ord. nov. within the class 'Epsilonproteobacteria', isolated from a deep-sea hydrothermal vent. Int J Syst Evol Microbiol 54: 41-45.

Mottl, M., Seewald, J., Wheat, C., Tivey, M., Michael, P., Proskurowski, G. et al. (2011) Chemistry of hot springs along the Eastern Lau Spreading Center. Geochimica Et Cosmochimica Acta 75: 1013-1038.

Moussard, H., Moreira, D., Cambon-Bonavita, M., López-García, P., and Jeanthon, C. (2006a) Uncultured Archaea in a hydrothermal microbial assemblage: phylogenetic diversity and characterization of a genome fragment from a euryarchaeote. FEMS microbiology ecology 57: 452-469.

Moussard, H., Henneke, G., Moreira, D., Jouffe, V., Lopez-Garcia, P., and Jeanthon, C. (2006b) Thermophilic lifestyle for an uncultured archaeon from hydrothermal vents: evidence from environmental genomics. Appl Environ Microbiol 72: 2268-2271.

Moussard, H., L'Haridon, S., Tindall, B.J., Banta, A., Schumann, P., Stackebrandt, E. et al. (2004) Thermodesulfatator indicus gen. nov., sp. nov., a novel thermophilic 
chemolithoautotrophic sulfate-reducing bacterium isolated from the Central Indian Ridge. Int J Syst Evol Microbiol 54: 227-233.

Nakagawa, S., Inagaki, F., Takai, K., Horikoshi, K., and Sako, Y. (2005a) Thioreductor micantisoli gen. nov., sp. nov., a novel mesophilic, sulfur-reducing chemolithoautotroph within the epsilon-Proteobacteria isolated from hydrothermal sediments in the Mid-Okinawa Trough. Int J Syst Evol Microbiol 55: 599-605.

Nakagawa, S., Takai, K., Inagaki, F., Horikoshi, K., and Sako, Y. (2005b) Nitratiruptor tergarcus gen. nov., sp. nov. and Nitratifractor salsuginis gen. nov., sp. nov., nitrate-reducing chemolithoautotrophs of the epsilon-Proteobacteria isolated from a deep-sea hydrothermal system in the Mid-Okinawa Trough. Int J Syst Evol Microbiol 55: 925-933.

Nakagawa, S., Takai, K., Inagaki, F., Hirayama, H., Nunoura, T., Horikoshi, K., and Sako, Y. (2005c) Distribution, phylogenetic diversity and physiological characteristics of epsilon-Proteobacteria in a deep-sea hydrothermal field. Environ Microbiol 7: 1619-1632.

Nakagawa, S., Takai, K., Inagaki, F., Chiba, H., Ishibashi, J., Kataoka, S. et al. (2005d) Variability in microbial community and venting chemistry in a sediment-hosted backarc hydrothermal system: Impacts of subseafloor phase-separation. FEMS Microbiol Ecol 54: 141-155.

Nakagawa, T., Takai, K., Suzuki, Y., Hirayama, H., Konno, U., Tsunogai, U., and Horikoshi, K. (2006) Geomicrobiological exploration and characterization of a 
novel deep-sea hydrothermal system at the TOTO caldera in the Mariana Volcanic Arc. Environ Microbiol 8: 37-49.

Nawrocki, E.P., Kolbe, D.L., and Eddy, S.R. (2009) Infernal 1.0: inference of RNA alignments. Bioinformatics 25: 1335-1337.

Nelson, D.C., Wirsen, C.O., and Jannasch, H.W. (1989) Characterization of large, autotrophic Beggiatoa spp. abundant at hydrothermal vents of the Guaymas Basin. Appl Environ Microbiol 55: 2909-2917.

Nercessian, O., Reysenbach, A.L., Prieur, D., and Jeanthon, C. (2003) Archaeal diversity associated with in situ samplers deployed on hydrothermal vents on the East Pacific Rise (13 degrees N). Environ Microbiol 5: 492-502.

Nunoura, T., and Takai, K. (2009) Comparison of microbial communities associated with phase-separation-induced hydrothermal fluids at the Yonaguni Knoll IV hydrothermal field, the Southern Okinawa Trough. FEMS Microbiol Ecol 67: $351-370$.

Nunoura, T., Oida, H., Nakaseama, M., Kosaka, A., Ohkubo, S.B., Kikuchi, T. et al. (2010) Archaeal diversity and distribution along thermal and geochemical gradients in hydrothermal sediments at the Yonaguni Knoll IV hydrothermal field in the Southern Okinawa trough. Appl Environ Microbiol 76: 1198-1211.

Omer, A.D., Lowe, T.M., Russell, A.G., Ebhardt, H., Eddy, S.R., and Dennis, P.P. (2000) Homologs of small nucleolar RNAs in Archaea. Science 288: 517-522. 
Opatkiewicz, A.D., Butterfield, D.A., and Baross, J.A. (2009) Individual hydrothermal vents at Axial Seamount harbor distinct subseafloor microbial communities. Fems Microbiology Ecology 70: 413-424.

Page, A., Tivey, M.K., Stakes, D.S., and Reysenbach, A.L. (2008) Temporal and spatial archaeal colonization of hydrothermal vent deposits. Environ Microbiol 10: 874884.

Papke, R.T., Ramsing, N.B., Bateson, M.M., and Ward, D.M. (2003) Geographical isolation in hot spring cyanobacteria. Environ Microbiol 5: 650-659.

Perner, M., Kuever, J., Seifert, R., Pape, T., Koschinsky, A., Schmidt, K. et al. (2007) The influence of ultramafic rocks on microbial communities at the Logatchev hydrothermal field, located 15 degrees $\mathrm{N}$ on the Mid-Atlantic Ridge. FEMS Microbiol Ecol 61: 97-109.

Prokofeva, M., Miroshnichenko, M., Kostrikina, N., Chernyh, N., Kuznetsov, B., Tourova, T., and Bonch-Osmolovskaya, E. (2000) Acidilobus aceticus gen. nov., sp. nov., a novel anaerobic thermoacidophilic archaeon from continental hot vents in Kamchatka. Int J Syst Evol Microbiol 50: 2001.

Prokofeva, M.I., Kostrikina, N.A., Kolganova, T.V., Tourova, T.P., Lysenko, A.M., Lebedinsky, A.V., and Bonch-Osmolovskaya, E.A. (2009) Isolation of the anaerobic thermoacidophilic crenarchaeote Acidilobus saccharovorans sp. nov. and proposal of Acidilobales ord. nov., including Acidilobaceae fam. nov. and Caldisphaeraceae fam. nov. Int J Syst Evol Microbiol 59: 3116-3122. 
Pruesse, E., Quast, C., Knittel, K., Fuchs, B.M., Ludwig, W., Peplies, J., and Glockner, F.O. (2007) SILVA: a comprehensive online resource for quality checked and aligned ribosomal RNA sequence data compatible with ARB. Nucleic Acids Res 35: 7188-7196.

Quince, C., Lanzen, A., Davenport, R., and Turnbaugh, P. (2011) Removing noise from pyrosequenced amplicons. BMC Bioinformatics 12: 38 .

Ramirez-Llodra, E., Shank, T.M., and German, C.R. (2007) Biodiversity and biogeography of hydrothermal vent species. Oceanography 20: 30-41.

Reno, M.L., Held, N.L., Fields, C.J., Burke, P.V., and Whitaker, R.J. (2009) Biogeography of the Sulfolobus islandicus pan-genome. Proc Natl Acad Sci U S A 106: $8605-8610$.

Reysenbach, A.-L., Götz, D., and Yernool, D. (2002) Microbial diversity of marine and terrestrial thermal springs. In Biodiversity of Microbial Life. Staley, J.T., and Reysenbach, A.-L. (eds). New York: Wiley-Liss, Inc., pp. 345-421.

Reysenbach, A.L., and Flores, G.E. (2008) Electron microscopy encounters with unusual thermophiles helps direct genomic analysis of Aciduliprofundum boonei. Geobiology 6: 331-336.

Reysenbach, A.L., Longnecker, K., and Kirshtein, J. (2000) Novel bacterial and archaeal lineages from an in situ growth chamber deployed at a Mid-Atlantic Ridge hydrothermal vent. Appl Environ Microbiol 66: 3798-3806. 
Reysenbach, A.L., Liu, Y., Banta, A.B., Beveridge, T.J., Kirshtein, J.D., Schouten, S. et al. (2006) A ubiquitous thermoacidophilic archaeon from deep-sea hydrothermal vents. Nature 442: 444-447.

Rinker, K.D., and Kelly, R.M. (2000) Effect of carbon and nitrogen sources on growth dynamics and exopolysaccharide production for the hyperthermophilic archaeon Thermococcus litoralis and bacterium Thermotoga maritima. Biotechnology and Bioengineering 69: 537-547.

Rogers, D.R., Santelli, C.M., and Edwards, K.J. (2003) Geomicrobiology of deep sea deposits: estimating community diversity from low temperature seafloor rocks and minerals. Geobiology 1: 109-117.

Rouxel, O., Fouquet, Y., and Ludden, J.N. (2004a) Copper isotope systematics of the Lucky Strike, Rainbow, and Logatchev sea-floor hydrothermal fields on the Mid-Atlantic Ridge. Economic Geology and the Bulletin of the Society of Economic Geologists 99: 585-600.

Rouxel, O., Fouquet, Y., and Ludden, J.N. (2004b) Subsurface processes at the Lucky Strike hydrothermal field, Mid-Atlantic Ridge: Evidence from sulfur, selenium, and iron isotopes. Geochimica Et Cosmochimica Acta 68: 2295-2311.

Ruan, Q., Dutta, D., Schwalbach, M.S., Steele, J.A., Fuhrman, J.A., and Sun, F. (2006) Local similarity analysis reveals unique associations among marine bacterioplankton species and environmental factors. Bioinformatics 22: 25322538. 
Sako, Y., Nomura, N., Uchida, A., Ishida, Y., Morii, H., Koga, Y. et al. (1996) Aeropyrum pernix gen. nov., sp. nov., a novel aerobic hyperthermophilic archaeon growing at temperatures up to 100 degrees C. International journal of systematic bacteriology 46: 1070-1077.

Sarrazin, J., and Juniper, S.K. (1999) Biological characteristics of a hydrothermal edifice mosaic community. Marine Ecology-Progress Series 185: 1-19.

Schloss, P. (2010) The effects of alignment quality, distance calculation method, sequence filtering, and region on the analysis of 16S rRNA gene-based studies. PLoS Comput Biol 6: e1000844.

Schmidt, K., Koschinsky, A., Garbe-Schonberg, D., de Carvalho, L.M., and Seifert, R. (2007) Geochemistry of hydrothermal fluids from the ultramafic-hosted Logatchev hydrothermal field, 15 degrees $\mathrm{N}$ on the Mid-Atlantic Ridge: Temporal and spatial investigation. Chemical Geology 242: 1-21.

Schrenk, M.O., Kelley, D.S., Delaney, J.R., and Baross, J.A. (2003) Incidence and diversity of microorganisms within the walls of an active deep-sea sulfide chimney. Appl Environ Microbiol 69: 3580-3592.

Seewald, J.S., Zolotov, M.Y., and McCollom, T. (2006) Experimental investigation of single carbon compounds under hydrothermal conditions. Geochimica Et Cosmochimica Acta 70: 446-460.

Seewald, J.S., Doherty, K.W., Hammar, T.R., and Liberatore, S.P. (2002) A new gastight isobaric sampler for hydrothermal fluids. Deep-Sea Research Part IOceanographic Research Papers 49: 189-196. 
Seyfried, W., Pester, N.J., Ding, K., and Rough, M. (2011) Vent fluid chemistry of the Rainbow Hydrothermal System (36 $6^{\circ}$, MAR): Phase equilibria and in-situ $\mathrm{pH}$ controls on subseafloor alteration processes. Geochimica Et Cosmochimica Acta 75: $1574-1593$.

Seyfried, W.E., Jr., and Mottl, M.J. (1995) Geologic setting and chemistry of deep-sea hydrothermal vents. In The Microbiology of Deep-Sea Hydrothermal Vents. Karl, D.M. (ed). Boca Raton, FL: CRC Press, pp. 1-34.

Shannon, P., Markiel, A., Ozier, O., Baliga, N.S., Wang, J.T., Ramage, D. et al. (2003) Cytoscape: a software environment for integrated models of biomolecular interaction networks. Genome Res 13: 2498-2504.

Shock, E.L., and Holland, M.E. (2004) Geochemical energy sources that support the subsurface biosphere. In Subseafloor biosphere at Mid-Ocean Ridges. Wilcock, W., Cary, C., DeLong, E., Kelley, D., and Baross, J. (eds). Washington, DC: American Geophyscial Union, pp. 153-165.

Shock, E.L., McCollom, T., and Schulte, M.D. (1995) Geochemical constraints on chemolithoautotrophic reactions in hydrothermal systems. Origins of Life and Evolution of the Biosphere 25: 141-159.

Singh, S.C., Crawford, W.C., Carton, H., Seher, T., Combier, V., Cannat, M. et al. (2006) Discovery of a magma chamber and faults beneath a Mid-Atlantic Ridge hydrothermal field. Nature 442: 1029-1032.

Smith, J.L., Campbell, B.J., Hanson, T.E., Zhang, C.L., and Cary, S.C. (2008) Nautilia profundicola sp. nov., a thermophilic, sulfur-reducing epsilonproteobacterium 
from deep-sea hydrothermal vents. International Journal of Systematic and Evolutionary Microbiology 58: 1598-1602.

Sogin, M.L., Morrison, H.G., Huber, J.A., Mark Welch, D., Huse, S.M., Neal, P.R. et al. (2006) Microbial diversity in the deep sea and the underexplored "rare biosphere". Proc Natl Acad Sci U S A 103: 12115-12120.

Stamatakis, A. (2006) RAxML-VI-HPC: maximum likelihood-based phylogenetic analyses with thousands of taxa and mixed models. Bioinformatics 22: 26882690.

Stetter, K. (1988) Archaeoglobus fulgidus gen. nov., sp. nov.: A new taxon of extremely thermophilic archaebacteria. Systematic and applied microbiology 10: 172-173.

Stott, M.B., Saito, J.A., Crowe, M.A., Dunfield, P.F., Hou, S., Nakasone, E. et al. (2008) Culture-independent characterization of a novel microbial community at a hydrothermal vent at Brothers volcano, Kermadec arc, New Zealand. Journal of Geophysical Research-Solid Earth 113: B08S06.

Sunamura, M., Higashi, Y., Miyako, C., Ishibashi, J., and Maruyama, A. (2004) Two bacteria phylotypes are predominant in the Suiyo seamount hydrothermal plume. Appl Environ Microbiol 70: 1190-1198.

Suzuki, M.T., and Giovannoni, S.J. (1996) Bias caused by template annealing in the amplification of mixtures of 16S rRNA genes by PCR. Appl Environ Microbiol 62: $625-630$. 
Suzuki, Y., Inagaki, F., Takai, K., Nealson, K.H., and Horikoshi, K. (2004) Microbial diversity in inactive chimney structures from deep-sea hydrothermal systems. Microb Ecol 47: 186-196.

Takai, K., and Horikoshi, K. (1999) Genetic diversity of archaea in deep-sea hydrothermal vent environments. Genetics 152: 1285-1297.

Takai, K., and Horikoshi, K. (2000a) Rapid detection and quantification of members of the archaeal community by quantitative PCR using fluorogenic probes. Appl Environ Microbiol 66: 5066-5072.

Takai, K., and Horikoshi, K. (2000b) Thermosipho japonicus sp. nov., an extremely thermophilic bacterium isolated from a deep-sea hydrothermal vent in Japan. Extremophiles 4: 9-17.

Takai, K., and Nakamura, K. (2010) Compositional, physiological and metabolic variability in microbial communities associated with geochemically diverse, deep-sea hydrothermal vent fluids. Geomicrobiology: Molecular and Environmental Perspective: 251-283.

Takai, K., Inoue, A., and Horikoshi, K. (2002) Methanothermococcus okinawensis sp. nov., a thermophilic, methane-producing archaeon isolated from a Western Pacific deep-sea hydrothermal vent system. Int J Syst Evol Microbiol 52: 10891095.

Takai, K., Sugai, A., Itoh, T., and Horikoshi, K. (2000) Palaeococcus ferrophilus gen. nov., sp. nov., a barophilic, hyperthermophilic archaeon from a deep-sea hydrothermal vent chimney. Int J Syst Evol Microbiol 50: 489-500. 
Takai, K., Komatsu, T., Inagaki, F., and Horikoshi, K. (2001) Distribution of Archaea in a black smoker chimney structure. Appl Environ Microbiol 67: 3618-3629.

Takai, K., Nakagawa, T., Reysenbach, A.L., and Hoek, J. (2006a) Microbial ecology of Mid-Ocean Ridges and Back-Arc Basins. In Back-Arc Spreading Systems: geological, biological, chemical, and physical interactions. Christie, D.M., Fisher, C.R., Sang-Mook, L., and Givens, S. (eds). Washington, DC: American Geophysical Union, pp. 185-213.

Takai, K., Hirayama, H., Nakagawa, T., Suzuki, Y., Nealson, K.H., and Horikoshi, K. (2004a) Thiomicrospira thermophila sp. nov., a novel microaerobic, thermotolerant, sulfur-oxidizing chemolithomixotroph isolated from a deep-sea hydrothermal fumarole in the TOTO caldera, Mariana Arc, Western Pacific. Int J Syst Evol Microbiol 54: 2325-2333.

Takai, K., Hirayama, H., Nakagawa, T., Suzuki, Y., Nealson, K.H., and Horikoshi, K. (2005) Lebetimonas acidiphila gen. nov., sp. nov., a novel thermophilic, acidophilic, hydrogen-oxidizing chemolithoautotroph within the 'Epsilonproteobacteria', isolated from a deep-sea hydrothermal fumarole in the Mariana Arc. Int J Syst Evol Microbiol 55: 183-189.

Takai, K., Nakamura, K., Suzuki, K., Inagaki, F., Nealson, K., and Kumagai, H. (2006b) Ultramafics-Hydrothermalism-Hydrogenesis-HyperSLiME (UltraH3) linkage: a key insight into early microbial ecosystem in the Archean deep-sea hydrothermal systems. Paleontological Research 10: 269-282. 
Takai, K., Gamo, T., Tsunogai, U., Nakayama, N., Hirayama, H., Nealson, K.H., and Horikoshi, K. (2004b) Geochemical and microbiological evidence for a hydrogen-based, hyperthermophilic subsurface lithoautotrophic microbial ecosystem (HyperSLiME) beneath an active deep-sea hydrothermal field. Extremophiles 8: 269-282.

Takai, K., Inagaki, F., Nakagawa, S., Hirayama, H., Nunoura, T., Sako, Y. et al. (2003) Isolation and phylogenetic diversity of members of previously uncultivated epsilon-Proteobacteria in deep-sea hydrothermal fields. FEMS Microbiol Lett 218: $167-174$.

Takai, K., Nunoura, T., Ishibashi, J., Lupton, J., Suzuki, R., Hamasaki, H. et al. (2008) Variability in the microbial communities and hydrothermal fluid chemistry at the newly discovered Mariner hydrothermal field, southern Lau Basin. Journal of Geophysical Research 113: G02031.

Tamura, K., Dudley, J., Nei, M., and Kumar, S. (2007) MEGA4: Molecular Evolutionary Genetics Analysis (MEGA) software version 4.0. Mol Biol Evol 24: $1596-1599$.

Tazumi, A., Kakinuma, Y., Misawa, N., Moore, J.E., Millar, B.C., and Matsuda, M. (2009) Identification and characterization of intervening sequences within 23S rRNA genes from more than 200 Campylobacter isolates from seven species including atypical campylobacters. BMC Microbiol 9: 256.

Tazumi, A., Nakanishi, S., Meguro, S., Kakinuma, Y., Moore, J.E., Millar, B.C., and Matsuda, M. (2010) Occurrence and characterisation of intervening sequences 
(IVSs) within 16S rRNA genes from two atypical Campylobacter species, $C$. sputorum and C. curvus. Br J Biomed Sci 67: 77-81.

Teyssier, C., Marchandin, H., Simeon De Buochberg, M., Ramuz, M., and Jumas-Bilak, E. (2003) Atypical 16S rRNA gene copies in Ochrobactrum intermedium strains reveal a large genomic rearrangement by recombination between rrn copies. $J$ Bacteriol 185: 2901-2909.

Tivey, M., Craddock, P., Seewald, J., Ferrini, V., Kim, S., Mottl, M. et al. (2005) Characterization of six vent fields within the Lau Basin. In American Geophysical Union, Fall meeting: American Geophysical Union, pp. T31A0477 .

Tivey, M.K. (2004) Environmental conditions within active seafloor vent structures: sensitivity to vent fluid composition and fluid flow. In Subseafloor Biosphere at Mid-Ocean Ridges. Wilcock, W., Cary, C., DeLong, E., Kelley, D., and Baross, J. (eds). Washington, DC: American Geophysical Union, pp. 137-152.

Tivey, M.K. (2007) Generation of seafloor hydrothermal vent fluids and associated mineral deposits. Oceanography 20: 50-65.

Tor, J.M., Kashefi, K., and Lovley, D.R. (2001) Acetate oxidation coupled to Fe (III) reduction in hyperthermophilic microorganisms. Applied and Environmental Microbiology 67: 1363-1365.

Van Dover, C.L. (2000) The Ecology of Dee-Sea Hydrothermal Vents. Princeton, New Jersey: Princeton University Press. 
Van Dover, C.L., Reynolds, G.T., Chave, A.D., and Tyson, J.A. (1996) Light at deepsea hydrothermal vents. Geophysical research letters 23: 2049-2052.

Vannier, P., Marteinsson, V.T., Fridjonsson, O.H., Oger, P., and Jebbar, M. (2011) Complete genome sequence of the hyperthermophilic piezophilic, heterotrophic and carboxydotrophic archaeon Thermococcus barophilus MP. Journal of bacteriology: JB. 01490-01410v01491.

Villemur, R., Constant, P., Gauthier, A., Shareck, M., and Beaudet, R. (2007) Heterogeneity between $16 \mathrm{~S}$ ribosomal RNA gene copies borne by one Desulfitobacterium strain is caused by different $100-200$ bp insertions in the $5^{\prime}$ region. Can J Microbiol 53: 116-128.

Von Damm, K., Bray, A., Buttermore, L., and Oosting, S. (1998) The geochemical controls on vent fluids from the Lucky Strike vent field, Mid-Atlantic Ridge. Earth and Planetary Science Letters 160: 521-536.

Von Damm, K.L. (1995) Controls on the chemistry and temporal variability of seafloor hydrothermal fluids. In Seafloor Hydrothermal Systems: Physical, Chemical, Biological, and Geological Interactions. Humphris, S.E., Zierenberg, R. A., Mullineaux, L. S., Thomson, R. E. (ed). Washington, DC: American Geophysical Union, pp. 222-247.

Voordeckers, J.W., Starovoytov, V., and Vetriani, C. (2005) Caminibacter mediatlanticus sp. nov., a thermophilic, chemolithoautotrophic, nitrateammonifying bacterium isolated from a deep-sea hydrothermal vent on the MidAtlantic Ridge. Int J Syst Evol Microbiol 55: 773-779. 
Voordeckers, J.W., Do, M.H., Hugler, M., Ko, V., Sievert, S.M., and Vetriani, C. (2008) Culture dependent and independent analyses of 16S rRNA and ATP citrate lyase genes: a comparison of microbial communities from different black smoker chimneys on the Mid-Atlantic Ridge. Extremophiles 12: 627-640.

Wang, Q., Garrity, G.M., Tiedje, J.M., and Cole, J.R. (2007) Naive Bayesian classifier for rapid assignment of rRNA sequences into the new bacterial taxonomy. Appl Environ Microbiol 73: 5261-5267.

Whitaker, R.J., Grogan, D.W., and Taylor, J.W. (2003) Geographic barriers isolate endemic populations of hyperthermophilic archaea. Science 301: 976-978.

White, J.R., Navlakha, S., Nagarajan, N., Ghodsi, M.R., Kingsford, C., and Pop, M. (2010) Alignment and clustering of phylogenetic markers--implications for microbial diversity studies. BMC Bioinformatics 11: 152.

Wilson, T., Amirbahman, A., Norton, S., and Voytek, M. (2010) A record of phosphorus dynamics in oligotrophic lake sediment. Journal of Paleolimnology 44: 279-294.

Winn, C.D., Cowen, J.P., and Karl, D.M. (1995) Microbes in deep-sea hydrothermal plumes. In The Microbiology of Deep-Sea Hydrothermal Vents. Karl, D.M. (ed). New York, NY: CRC Press, pp. 255-273.

Yurkov, V., and Beatty, J.T. (1998) Isolation of aerobic anoxygenic photosynthetic bacteria from black smoker plume waters of the juan de fuca ridge in the pacific ocean. Appl Environ Microbiol 64: 337-341. 
Zhou, H., Li, J., Peng, X., Meng, J., Wang, F., and Ai, Y. (2009) Microbial diversity of a sulfide black smoker in main endeavour hydrothermal vent field, Juan de Fuca Ridge. The Journal of Microbiology 47: 235-247.

Zivanovic, Y., Armengaud, J., Lagorce, A., Leplat, C., Guérin, P., Dutertre, M. et al. (2009) Genome analysis and genome-wide proteomics of Thermococcus gammatolerans, the most radioresistant organism known amongst the Archaea. Genome Biol 10: R70. 


\section{Appendix A: Sulfurihydrogenibium kristjanssonii sp. nov., a hydrogen and sulfur- oxidizing thermophile isolated from a terrestrial Icelandic hot spring.}

Flores, GE, Liu, Y, Ferrera, I, Beveridge, TJ and Reysenbach, A-L (2008) International Journal of Systematic and Evolutionary Microbiology 58: 1153-1158.

\section{Summary}

Three thermophilic, aerobic, hydrogen- and sulfur-oxidizing bacteria were isolated from an Icelandic hot spring near the town of Hveragerdi and were determined to share $>99 \% 16 \mathrm{~S}$ rRNA gene sequence similarity. One of these isolates, designated strain $\mathrm{I} 6628^{\mathrm{T}}$, was selected for further characterization. Strain $\mathrm{I} 6628^{\mathrm{T}}$ is a motile rod, 1.5-2.5 $\mu \mathrm{m}$ long and about $0.5 \mu \mathrm{m}$ wide. Growth occurred between 40 and $73^{\circ} \mathrm{C}$ (optimally at $68^{\circ} \mathrm{C}$ ), at $\mathrm{pH} 5.3-7.8$ (optimally at $\mathrm{pH} 6.6$ ) and at $\mathrm{NaCl}$ concentrations between 0 and $0.5 \%(\mathrm{w} / \mathrm{v})$. Strain $\mathrm{I}_{6} 628^{\mathrm{T}}$ grew with $\mathrm{H}_{2}, \mathrm{~S}^{0}$ or $\mathrm{S}_{2} \mathrm{O}_{3}{ }^{2-}$ as an electron donor with $\mathrm{O}_{2}$ (up to $25 \%$, v/v; optimally at 4-9\%) as the sole electron acceptor. $\mathrm{CO}_{2}$ and succinate were utilized as carbon sources but no organic compounds, including succinate, could be used as an energy source. The $\mathrm{G}+\mathrm{C}$ content of the genomic DNA was determined to be $28.1 \mathrm{~mol} \%$. Phylogenetic analysis of the $16 \mathrm{~S}$ rRNA gene sequence indicated that strain $\mathrm{I}_{6} 628^{\mathrm{T}}$ is a member of the genus Sulfurihydrogenibium, the closest cultivated relative being the recently described strain Sulfurihydrogenibium rodmanii UZ3 $-5^{\mathrm{T}}$ (98.2\% sequence similarity). On the basis of the physiology and 
phylogeny of this organism, strain $16628^{\mathrm{T}}$ represents a novel species of the genus Sulfurihydrogenibium, for which the name Sulfurihydrogenibium kristjanssonii sp. nov. is proposed. The type strain is I6628T $\left(=\mathrm{DSM} 19534^{\mathrm{T}}=\mathrm{OCM} 901^{\mathrm{T}}=\mathrm{ATCC}\right.$ BAA$\left.1535^{\mathrm{T}}\right)$. 


\title{
Appendix B: Electron microscopy encounters with unusual thermophiles helps direct genomic analysis of Aciduliprofundum boonei.
}

Reysenbach, A-L and Flores, GE (2008) Geobiology 6: 331-336.

\begin{abstract}
Terry Beveridge's enthusiasm about the ingenuity of microorganisms has stimulated many new avenues of microbial research. One example where Terry's observations helped direct the scientific process was in the analysis of the draft genome of the thermoacidophilic archaeum, Aciduliprofundum boonei. This deep-sea vent heterotroph ferments peptides as its primary metabolic pathway, using numerous enzymes encoding for proteolytic or peptidolytic activities. An almost complete modified Embden-Meyerhof-Parnas pathway operates in the gluconeogenic direction. Terry was particularly intrigued by the S-layer and flagellum of A. boonei. Although only putative genes for the S-layer protein could be identified, several genes encoding for glycosyl transferases were located in the draft genome that could glycosylate the Slayer proteins and protect the proteins from the acidic environment. Furthermore, $A$. boonei possesses a unique organization to its flagellum genes and may represent a third organizational type within the Archaea.
\end{abstract}




\section{Appendix C: Summary of MAR 16S rRNA gene clones}

All archaeal and bacterial sequences have been deposited to GenBank under accession numbers HQ893885-HQ894378. Files are archived in the share_alrlab\MAR08 Clones on the PSU research server.

Table 1: Summary of archaeal clones detected in deposits from the Mid-Atlantic Ridge. Classifications were made using the RDP-classifier.

\begin{tabular}{|c|c|c|c|c|c|c|c|c|c|c|}
\hline \multirow{2}{*}{$\frac{\text { Taxa affiliation }}{\text { Euryarchaeota }}$} & \multicolumn{10}{|c|}{ Archaeal Clone Frequency (\%) } \\
\hline & \multicolumn{2}{|c|}{$\mathrm{Rb}-2$} & \multicolumn{2}{|r|}{$\overline{\mathrm{Rb}-5}$} & \multicolumn{2}{|c|}{$\mathrm{Rb}-6$} & \multicolumn{2}{|c|}{ LS-7 } & \multicolumn{2}{|c|}{ TAG-13 } \\
\hline Unclassified & 4 & $(5.80)$ & & & & & 7 & $(28.00)$ & & \\
\hline \multicolumn{11}{|l|}{ Archaeoglobi } \\
\hline \multicolumn{11}{|l|}{ Archaeoglobales } \\
\hline Unclassified & & & 1 & $(1.85)$ & 1 & $(1.47)$ & & & & \\
\hline \multicolumn{11}{|l|}{ Archaeoglobaceae } \\
\hline Archaeoglobus & 40 & $(57.97)$ & 29 & $(53.70)$ & 38 & $(55.88)$ & 12 & $(48.00)$ & 49 & $(94.23)$ \\
\hline Geoglobus & 2 & $(2.90)$ & & & & & & & 3 & $(5.77)$ \\
\hline \multicolumn{11}{|l|}{ Methanococci } \\
\hline \multicolumn{11}{|l|}{ Methanococcales } \\
\hline \multicolumn{11}{|l|}{ Methanocaldococcaceae } \\
\hline Methanocaldococcus & 14 & $(20.29)$ & 3 & $(5.56)$ & 4 & $(5.88)$ & & & & \\
\hline \multicolumn{11}{|l|}{ Methanococcaceae } \\
\hline Methanothermococcus & 2 & $(2.90)$ & 5 & $(9.26)$ & 1 & $(1.47)$ & & & & \\
\hline \multicolumn{11}{|l|}{ Thermococci } \\
\hline \multicolumn{11}{|l|}{ Thermococcales } \\
\hline \multicolumn{11}{|l|}{ Thermoccaceae } \\
\hline Unclassified & 1 & $(1.45)$ & & & & & & & & \\
\hline Thermococcus & 4 & $(5.80)$ & 14 & $(25.93)$ & 24 & $(35.29)$ & 1 & $(4.00)$ & & \\
\hline ‘Aciduliprofundales’ & & & & & & & 3 & $(12.00)$ & & \\
\hline \multicolumn{11}{|l|}{ Chrenarchaeota } \\
\hline \multicolumn{11}{|l|}{ Thermoprotei } \\
\hline Unclassified & & & & & & & 1 & $(4.00)$ & & \\
\hline \multicolumn{11}{|l|}{ Desulfurococcales } \\
\hline Unclassified & 1 & $(1.45)$ & & & & & & & & \\
\hline \multicolumn{11}{|l|}{ Desulfurococcaceae } \\
\hline Aeropyrum & 1 & $(1.45)$ & & & & & 1 & $(4.00)$ & & \\
\hline Staphylothermus & & & 2 & $(3.70)$ & & & & & & \\
\hline Total & 69 & & 54 & & 68 & & 25 & & 52 & \\
\hline
\end{tabular}


Table 2. Summary of bacterial clones detected in deposits from the Mid-Atlantic Ridge. Classifications were made using the RDP-classifier.

\begin{tabular}{|c|c|c|c|c|c|c|c|c|c|c|}
\hline \multirow[b]{2}{*}{ Taxa affiliation } & \multicolumn{10}{|c|}{ Bacterial Clone Frequency (\%) } \\
\hline & & $\mathrm{Rb}-2$ & & $\mathrm{Rb}-5$ & & $2 \mathrm{~b}-6$ & & $\mathrm{~S}-7$ & & $\mathrm{AG}-13$ \\
\hline \multicolumn{11}{|l|}{ Aquificae } \\
\hline \multicolumn{11}{|l|}{ Aquificales } \\
\hline Caldithrix & 1 & $(1.96)$ & & & & & & & & \\
\hline Thermovibrio & & & & & & & & & 1 & $(1.75)$ \\
\hline \multicolumn{11}{|l|}{ Bacteroidetes } \\
\hline Unclassified & 1 & $(1.96)$ & 1 & $(2.50)$ & & & 4 & $(6.67)$ & 1 & $(1.75)$ \\
\hline \multicolumn{11}{|l|}{ Flavobacteria } \\
\hline \multicolumn{11}{|l|}{ Flavobacteriales } \\
\hline Flavobacteriaceae & & & 1 & $(2.50)$ & & & & & & \\
\hline \multicolumn{11}{|l|}{ Sphingobacteria } \\
\hline \multicolumn{11}{|l|}{ Sphingobacteriales } \\
\hline Flexibacteraceae & 2 & $(3.92)$ & 1 & $(2.50)$ & & & & & & \\
\hline \multicolumn{11}{|l|}{ Deinococcus-Thermus } \\
\hline \multicolumn{11}{|l|}{ Deinococci } \\
\hline \multicolumn{11}{|l|}{ Thermales } \\
\hline \multicolumn{11}{|l|}{ Thermaceae } \\
\hline Oceanithermus & & & & & & & 4 & $(6.67)$ & & \\
\hline \multicolumn{11}{|l|}{ Proteobacteria } \\
\hline Unclassified & 1 & $(1.96)$ & 2 & $(5.00)$ & & & & & 1 & $(1.75)$ \\
\hline \multicolumn{11}{|l|}{ Alphaproteobacteria } \\
\hline \multicolumn{11}{|l|}{ Rhodobacterales } \\
\hline Rhodobacteraceae & 3 & $(5.88)$ & & & 1 & $(2.63)$ & & & & \\
\hline \multicolumn{11}{|l|}{ Deltaproteobacteria } \\
\hline \multicolumn{11}{|l|}{ Desulfobacterales } \\
\hline \multicolumn{11}{|l|}{ Desulfobulbaceae } \\
\hline Unclassified & & & & & & & 1 & $(1.67)$ & & \\
\hline Desulfobulbus & & & & & & & 1 & $(1.67)$ & & \\
\hline Desulfocapsa & & & 1 & $(2.50)$ & & & & & & \\
\hline Desulfotalea & & & & & & & & & 1 & $(1.75)$ \\
\hline Epsilonproteobacteria & & & & & & & & & & \\
\hline Unclassified & 2 & $(3.92)$ & & & & & 18 & $(30.00)$ & 15 & $(26.32)$ \\
\hline Campylobacterales & & & & & & & & & & \\
\hline Unclassified & 1 & $(1.96)$ & 1 & $(2.50)$ & 2 & $(5.26)$ & 7 & (11.67) & 7 & (12.28) \\
\hline Campylobacteraceae & & & & & & & & & & \\
\hline Sulfurospirillum & & & 3 & $(7.50)$ & 3 & $(7.89)$ & 2 & (3.33) & & \\
\hline Helicobacteraceae & & & & & & & & & & \\
\hline Unclassified & & & 1 & $(2.50)$ & 1 & $(2.63)$ & 2 & (3.33) & 2 & $(3.51)$ \\
\hline Sulfurovum & 13 & (25.49) & 18 & $(45.00)$ & 23 & $(60.53)$ & 8 & (13.33) & 18 & $(31.58)$ \\
\hline Sulfurimonas & & & 8 & (20.00) & 7 & $(18.42)$ & 1 & $(1.67)$ & & \\
\hline Hydrogenimonaceae & & & & & & & & & & \\
\hline Hydrogenimonas & 10 & $(19.61)$ & & & & & 4 & $(6.67)$ & 1 & $(1.75)$ \\
\hline Nautiliales & & & & & & & & & & \\
\hline Unclassified & & & & & & & 1 & $(1.67)$ & & \\
\hline Nautiliaceae & & & & & & & & & & \\
\hline Caminibacter & & & & & & & 2 & (3.33) & 4 & $(7.02)$ \\
\hline Nautilia & & & & & & & & & 1 & $(1.75)$ \\
\hline Nitratiruptor & & & & & & & 1 & $(1.67)$ & & \\
\hline Nitratifractor & 2 & $(3.92)$ & & & & & 2 & (3.33) & 4 & $(7.02)$ \\
\hline
\end{tabular}




\begin{tabular}{|c|c|c|c|c|c|c|c|c|c|}
\hline \multicolumn{10}{|l|}{ Gammaproteobacteria } \\
\hline Unclassified & 12 & $(23.53)$ & 1 & $(2.50)$ & 1 & $(2.63)$ & & & $1 \quad(1.75)$ \\
\hline \multicolumn{10}{|l|}{ Methylococcales } \\
\hline Methylococcaceae & 2 & $(3.92)$ & & & & & 1 & $(1.67)$ & \\
\hline \multicolumn{10}{|l|}{ Thiotrichales } \\
\hline \multicolumn{10}{|l|}{ Piscirickettsiaceae } \\
\hline Thiomicrospira & 1 & $(1.96)$ & & & & & & & \\
\hline \multicolumn{10}{|l|}{ Thiotrichaceae } \\
\hline Leucothrix & & & 2 & $(5.00)$ & & & & & \\
\hline \multicolumn{10}{|l|}{ Thermodesulfobacteria } \\
\hline \multicolumn{10}{|l|}{ Thermodesulfobacteriales } \\
\hline Thermodesulfobacteriaceae & & & & & & & 1 & $(1.67)$ & \\
\hline Total & 51 & & 40 & & 38 & & 60 & & 57 \\
\hline
\end{tabular}

